\title{
INTERBLOCK ZONES IN THE CRUST OF THE SOUTHERN REGIONS OF EAST SIBERIA: TECTONOPHYSICAL INTERPRETATION OF GEOLOGICAL AND GEOPHYSICAL DATA
}

\author{
K. Zh. Seminsky ${ }^{1}$, N. O. Kozhevnikov², A. V. Cheremnykh¹, E. V. Pospeeva ${ }^{2}$, \\ A. A. Bobrov ${ }^{1}$, V. V. Olenchenko ${ }^{2}$, M. A. Tugarina ${ }^{3}$, V. V. Potapov², \\ R. M. Zaripov ${ }^{1}$, A. S. Cheremnykh ${ }^{1}$ \\ ${ }^{1}$ Institute of the Earth's Crust SB RAS, Irkutsk, Russia \\ ${ }^{2}$ A.A. Trofimuk Institute of Petroleum Geology and Geophysics SB RAS, Novosibirsk, Russia \\ ${ }^{3}$ National Research Irkutsk State Technical University, Irkutsk, Russia
}

\begin{abstract}
The zone-block structure of the lithosphere is represented by a hierarchically organized pattern of stable blocks and mobile zones which border such blocks and contain highly dislocated geological medium (Fig. 1). Today, different specialists adhere to different concepts of blocks and zones, which are two main elements of the lithosphere structure. Differences are most significant in determinations of 'interblock zones' that are named as deformation / destructive / contact / mobile / fracture zones etc. due to their diversity in different conditions of deformation. One of the most effective approaches to studying the zone-block structure of the lithosphere is a combination of geological and geophysical studies of interblock zones tectonic features on various scales, which can make it possible to reveal the most common patterns of the interblock zones, general regularities of their development and relationships between the interblock zones.

The main objectives of our study were (1) to identify the zone-block structure of the crust in the southern regions of East Siberia from tectonophysical analysis of geological and geophysical surveys conducted on four different scales along the 500 km long Shertoy-Krasny Chikoy transect crossing the marginal segment of the Siberian block, the Baikal rift and the Transbaikalian block (Fig. 2); (2) to clarify structural features of the central part of the Baikal rift (representing the tectonic type of interblock extension zone) by applying new research methods, such as radon emanation survey, to the Shertoy-Krasny Chikoy transect and using the previously applied methods, such as magnetotelluric sounding, on a smaller scale; and (3) to study manifestation of interblock zones of various ranks in different geological and geophysical fields, to reveal common specific features of their structural patterns for the upper crust, and to establish regularities of hierarchic and spatial relationships between the interblock zones.

On the global scale, the object of our study at the Shertoy-Krasny Chikoy transect was the Baikal interblock zone (Fig. 2, 15, and 16). On the trans-regional scale, large fault zones were studied (Fig. 6, 11, and 14). On the regional and local scales, the objects of our study were systems of faults and fractures of various ranks which were active at the late Cenozoic stage of tectogenesis (Fig. 4, and 5). The set of geological and geophysical surveys included application of methods for identification of faults and fractures using different criteria, with account of the fact that clusters of such structures are indicative of the interblock zones of the crust. We used structural geological methods for studying faults and fractures, morphostructural analysis (including interpretation of satellite images), self-potential (SP) and resistivity profiling, magnetotelluric (MT) sounding, radon emanation survey, and hydrogeological studies of water occurrences. The region of Lake Baikal is one of the most studied geodynamically active regions of Russia; therefore, published data from previous studies of the Baikal region were used to interpret the data obtained by the authors.
\end{abstract}

By interpreting the obtained data from the unified tectonophysical positions, the three objectives were met, and the following research results were stated:

1. The principal specific features of the geological structure of the crust along the Shertoy-Krasny Chikoy transect are specified. It is established that the divisibility pattern complies with tectonophysical definitions of the hierarchically organized zone-block structure of the lithosphere (Fig. 2, 6, 11, 14, and 16). It is clearly evidenced, within the depth interval from the near-surface to about $30 \mathrm{~km}$, that the crust is split into slightly broken blocks that are in contact with each other via wide zones that are marked by higher fracturing and fluid saturation. To a first approximation, such blocks are shaped as subhorizontal plates in the stable southern regions of East Siberia (e.g., the southern part of the Siberian platform) and subvertical plates in the areas being active in the Cenozoic (e.g., the Baikal rift). Within the framework of the given model of the zoneblock structure of the southern regions of East Siberia, strict hierarchical subordination is established that manifests in spatial relationships of interblock zones (the closed network of the zones, imbedded blocks); its quantitative characteristics are stated at the global, trans-regional and three regional levels (Table 1, Fig. 2, Fig. 22). Average sizes of the zones, that were crossed by the transect, are estimated from the depth of their penetration into the crust; it is shown that Scale Invariant 2.2 (previously set for estimates of square areas) is valid also for the analysis of volumes of interblock structures. Detailed observations show 
that interblock structures are usually wider towards the earth surface; in the 1st order active zones, dimensions of the interblock structures may exceed dimensions of the adjacent, slightly disturbed blocks of the corresponding hierarchic level (Fig. $6,11,14$, and 16). This pattern is typical of the actively developing Baikal rift and determines specific features of its structure with regards to the zone-block divisibility of the lithosphere.

2. The Baikal interblock zone is a global one in the hierarchy of the zone-block structure of Asia. It develops under tension conditions at the contact of the Siberian and Trans-Baikal lithospheric blocks (Fig. 16). Within the transect, the width of the Baikal interblock zone is about $200 \mathrm{~km}$. At the trans-regional level of the hierarchy, the zone is comprised of the Obruchevsky, Chersky-Barguzin and Dzhida-Vitim fault systems (Fig. 6, 11, and 14). The first two of them act as the western and eastern borders of the subsided block of the Baikal basin and thus constitute the major area of the lithospheric extension. The second area is the Dzhida-Vitim fault system separating from the first one by the uplifted Khamar-Daban block; within the transect, it is morphologically manifested by the Ivolgino-Uda basin (Fig. 11, and 16). In this area, due to localization of deformation in the South Baikal basin, the process of fracturing is less pronounced, although indicators of the recent activity, such as seismicity, heat flow, gas emanations etc., are clearly at maximums over the Dzhida-Vitim zone, which makes it evident that this zone is distinguished from the adjacent Transbaikalian block (Fig. 15). Each of the three transregional fault systems has a width of about $50 \mathrm{~km}$ and consists of regional interblock zones that undergo the intensive development within the Baikal area wherein the crust is subject to extension (Fig. 6, 11, and 14). By their internal patterns, they represent zones of major faults: the Prikhrebtovy, Primorsky, and Morskoy faults constituting the Obruchevsky fault system, as well as the Bortovoy and Deltovy faults from the Chersky-Barguzin system. The Prikhrebtovy and Bortovoy fault zones are located at the periphery of the systems and flatten out in the direction of the rift axis from depths of about $20 \mathrm{~km}$, and, consequently, the area of the most intensive deformations in the Pribaikalie has a 'bowl-shaped' profile (Fig. 16). Due to the intensive fracturing occurring in the conditions of the overall stretching of the crust, this area is saturated with meteoric water and deep fluids penetrating into the regional fault zones and partially into the adjacent blocks also belonging to the internal pattern of the Obruchevsky and Chersky-Barguzin fault systems. The block represented by the Baikal basin (located between these two fault systems) is no exception as its central part is disturbed by the regional-scale zone wherein fluidization is most intense due to localization of deformation (Fig. 8, and 16). The zone of the anomalously low resistivity has a width of about 7-10 km and shows no trend to any drastic narrowing in the lower crust, which gives grounds to consider it as the main channel for migration of deep fluids towards the surface.

3. As shown by experiences gained during the research at the Shertoy-Krasny Chikoy transect, in East Siberia the applied methods and techniques are informative for identification and analyses of the internal patterns of the interblock zones of different ranks. The methods and techniques used in studies along the transect complement each other and make it possible to investigate different properties of interblock zones. In general, in comparison with blocks, the zones are distinguished by the relief lowering, anomalous water exchange conditions, gas anomalies that are positive and complex in shape, and low resistivity values both near the surface and at depth (Fig. 3-6, 8, and 11-16). Integrated interpretation of the data is challenging: when applied separately, the methods and techniques reveal various specific features of interblock zone that differ in the degree of heterogeneity of the internal patterns depending on conditions of their formation and development. At the current stage of research, the boundaries of the interblock zones can be determined, to a first approximation, from average positions of anomalies, to determine which the deviations of measured parameters from their mean values are used.

In the future, it is necessary to conduct detailed surveys using the above geological and geophysical methods in order to reveal specific features of manifestation of the interblock zones that differ in (1) kinematic types, ranks and degrees of activity, (2) properties of infill material and the surrounding medium, and (3) impacts of external factors (e.g., those of the planetary level). Upon comparison of results of such studies, it will be possible to update and improve the proposed generalized models accounting for manifestation of the interblock zones in the geological and geophysical fields (Fig. 17, 20, and 21) and to ensure that the methods and techniques used can be applied more effectively for identification of interblock zones in regions where rock outcrops are poor or lacking.

Key words: interblock zone, faults, blocks, hierarchy, transect, geological and geophysical methods, East Siberia, the Baikal rift.

Recommended by V.A. San'kov

Citation: Seminsky K.Zh., Kozhevnikov N.O., Cheremnykh A.V., Pospeeva E.V., Bobrov A.A., Olenchenko V.V., Tugarina M.A., Potapov V.V., Zaripov R.M., Cheremnykh A.S. 2013. Interblock zones in the crust of the southern regions of East Siberia: tectonophysical interpretation of geological and geophysical data. Geodynamics \& Tectonophysics 4 (3), 203-278. doi:10.5800/GT-2013-4-3-0099.

\title{
МЕЖБЛОКОВЫЕ ЗОНЫ В ЗЕМНОЙ КОРЕ ЮГА ВОСТОЧНОЙ СИБИРИ: ТЕКТОНОФИЗИЧЕСКАЯ ИНТЕРПРЕТАЦИЯ ГЕОЛОГО- ГЕОФИЗИЧЕСКИХ ДАННЫХ
}

\author{
К. Ж. Семинский ${ }^{1}$, Н. О. Кожевников ${ }^{2}$, А. В. Черемных ${ }^{1}$, Е. В. Поспеева ${ }^{2}$, \\ А. А. Бобров ${ }^{1}$, В. В. Оленченко ${ }^{2}$, М. А. Тугарина ${ }^{3}$, В. В. Потапов ${ }^{2}$, \\ Р. М. Зарипов ${ }^{1}$, А. С. Черемных ${ }^{1}$
}


${ }^{1}$ Институт земной коры СО РАН, Иркутск, Россия

${ }^{2}$ Институт нефтегазовой геологии и геофизики им. А.А. Трофимука СО РАН, Новосибирск, Россия

${ }^{3}$ Национальный исследовательский Иркутский государственный технический университет, Иркутск, Россия

Аннотация: Зонно-блоковая структура литосферы представляет собой иерархически организованную систему стабильных блоков и ограничивающих их подвижных зон, которые отличаются высокой дислоцированностью геологического субстрата (рис. 1). В настоящее время представления о каждом из двух главных элементов структуры литосферы (блоки и зоны) у разных специалистов отличаются друг от друга. Наибольшие разногласия имеют место при определении межблоковых зон, которые в литературе обозначаются различными терминами (деформационная, деструктивная, контактная, мобильная, разломная и др.), что связано с многообразием их проявлений в разных условиях деформации. Очевидно, одним из эффективных подходов к исследованию зонно-блоковой структуры литосферы является разномасштабное геолого-геофизическое изучение тектонотипов межблоковых зон, что позволит выделить наиболее общие закономерности их строения, развития и взаимоотношений друг с другом.

Главные задачи проведенного исследования: 1) выявить зонно-блоковую структуру земной коры юга Восточной Сибири на основе тектонофизического анализа результатов геолого-геофизических работ, проведенных в четырех разных масштабах на трансекте длиной 500 км (Шертой - Красный Чикой), который пересекает краевую часть Сибирского блока, Байкальский рифт и Забайкальский блок (рис. 2); 2) уточнить особенности строения центральной части Байкальского рифта - тектонотипа межблоковой зоны растяжения - путем применения на трансекте Шертой Красный Чикой новых видов исследования (например, эманационная съемка) и реализации ранее использованных методов в более крупном масштабе (например, магнитотеллурические зондирования); 3) исследовать проявление разноранговых межблоковых зон в различных геолого-геофизических полях и установить общие особенности их строения для верхней части земной коры, а также закономерности иерархических и пространственных взаимоотношений друг с другом.

Кроме Байкальской межблоковой зоны глобального уровня (рис. 2, 15, 16), объектами исследования на трансекте Шертой - Красный Чикой при проведении анализа в трансрегиональном масштабе являлись разломные системы (рис. 6, 11, 14), а в региональном и локальном масштабах - разноранговые разломные зоны (рис. 4, 5), активные на позднекайнозойском этапе тектогенеза. В комплекс геолого-геофизических работ были включены такие методы, которые позволяют по разным признакам выделять разрывные структуры, так как сгущения последних представляют межблоковые зоны земной коры. Это структурно-геологические методы изучения разрывов, морфотектонический анализ рельефа (в т.ч. дешифрирование космоснимков), электроразведка методами естественного электрического поля и электропрофилирования, магнитотеллурические зондирования, эманационная съемка, гидрогеологические исследования водопроявлений. В ходе комплексной интерпретации авторских материалов использовались опубликованные данные предыдущих исследований Прибайкалья, являющегося одним из наиболее изученных геодинамически активных регионов России.

Интерпретация полученных данных с единых тектонофизических позиций позволила решить три поставленные задачи и получить в рамках каждой из них результаты, представленные ниже.

1. Уточнены принципиальные особенности геологического строения земной коры вдоль трансекта Шертой Красный Чикой, выявлена картина тектонической делимости, и установлено ее соответствие тектонофизическим представлениям о иерархически организованной зонно-блоковой структуре литосферы (рис. 2, 6, 11, 14, 16). В приповерхностной части разреза и до глубины 30 км отчетливо проявлено деление земной коры на относительно слабонарушенные блоки, которые контактируют по широким субортогональным зонам, отличающимся повышенной дислоцированностью и флюидонасыщенностью. В первом приближении блоки имеют форму плит, занимающих субгоризонтальное положение в стабильных регионах юга Восточной Сибири (например, южная часть Сибирской плиты) и субвертикальное - в областях кайнозойской активизации (например, Байкальский рифт). В рамках такой модели для зонно-блоковой структуры юга Восточной Сибири установлена строгая иерархическая соподчиненность, которая проявляется в пространственных взаимоотношениях межблоковых зон (замкнутость сети зон, вложенный характер блоков) и количественно охарактеризована на глобальном, трансрегиональном и трех региональных уровнях (табл. 1, рис. 2, 22). Среднегеометрические размеры зон, пересеченных трансектом, рассчитаны с учетом глубины их проникновения в земную кору, и показано, что масштабный инвариант 2.2, установленный ранее для площадных оценок, справедлив и при анализе объемов межблоковых структур. При детальном рассмотрении межблоковые структуры обычно расширяются к поверхности и в тектонически активных зонах 1-го порядка могут превышать поперечные размеры смежных слабонарушенных блоков, соответствующих им по уровню иерархии (рис. $6,11,14$, 16). Подобная ситуация, характерная для активно развивающегося Байкальского рифта, определяет особенности его строения с позиций представлений о зонно-блоковой делимости литосферы.

2. Байкальская межблоковая зона относится к глобальному уровню иерархии в зонно-блоковой структуре Азии и развивается в режиме растяжения при контактировании Сибирского и Забайкальского блоков литосферы (рис. 16). Вдоль трассы трансекта она имеет ширину примерно 200 км и на трансрегиональном уровне иерархии состоит из Обручевской, Черско-Баргузинской и Джида-Витимской разломных систем (рис. 6, 11, 14). Первые две из них ограничивают с запада и востока опущенный блок Байкальской впадины и, таким образом, составляют главный участок растяжения литосферы. Второй участок представлен Джида-Витимской разломной системой, отделен от первого высокоподнятым Хамар-Дабанским блоком и в геоморфологическом отношении в пределах трансекта выражен Иволгино-Удинской впадиной (рис. 11, 16). Здесь, вследствие локализации деформации в районе Южно-Байкальской впадины, деструктивный процесс проявляется в меньшей степени, хотя индикаторы современной активности сейсмичность, тепловой поток, газовые эманации и др. - создают в Джида-Витимской зоне явно выраженные максимумы, которые отличают ее от смежной территории Забайкальского блока (рис. 15). Каждая из трех трансрегиональных разломных систем имеет ширину примерно 50 км и состоит из региональных межблоковых зон, интенсивно развивающихся в пределах байкальского участка растяжения земной коры (рис. 6, 11, 14). По типу внутреннего строения они представляют зоны крупных разломов: Прихребтового, Приморского и Морского - в Обручевской 
системе, а также Бортового и Дельтового - в Черско-Баргузинской системе. Прихребтовая и Бортовая разломные зоны, занимая в системах периферийное положение, выполаживаются в направлении оси рифта с глубин примерно 20 км, что придает характерный «чашеобразный» профиль участку наиболее интенсивных деформаций в Прибайкалье (рис. 16). Высокая степень деструкции на фоне общего растяжения коры приводит к насыщению этого участка флюидами за счет проникновения метеорных вод и глубинных растворов в региональные разломные зоны и, частично, в смежные блоки, которые также принадлежат к внутренней структуре Обручевской и Черско-Баргузинской разломных систем. Находящийся между ними блок Байкальской впадины в этом отношении не является исключением, так как нарушен в центре зоной регионального уровня, где вследствие локализации растяжения процесс флюидизации проявлен наиболее интенсивно (рис. 8, 16). Зона аномально низких сопротивлений имеет ширину $\approx 7-10$ км и не обнаруживает тенденции к резкому сужению в низах коры, что позволяет на данном этапе исследований считать ее главным каналом для миграции глубинных флюидов к поверхности.

3. Опыт, приобретенный в ходе исследований по трансекту Шертой - Красный Чикой, показал, что использовавшийся комплекс методов характеризуется высокой информативностью при выделении и анализе внутреннего строения разноранговых межблоковых зон, экспрессностью полевых измерений и возможностью применения в разнообразных условиях юга Восточной Сибири. Он включает методы, которые дополняют друг друга, что позволяет исследовать необходимый набор свойств межблоковых зон. В общем случае зоны выделяются по сравнению с пространствами блоков понижениями в рельефе, аномалиями условий водообмена, положительными и сложными по форме газовыми аномалиями, а также низкими значениями удельного электрического сопротивления как вблизи поверхности, так и на глубине (рис. 3-6, 8, 11-16). Сложность интерпретации комплексных данных заключается в том, что отдельными методами выявляются разные особенности межблоковых зон, которые в зависимости от условий формирования и развития отличаются по степени неоднородности внутреннего строения. На данном этапе исследований границы межблоковых зон могут в первом приближении успешно определяться по усредненному положению разнотипных аномалий, которые при их численном выражении отделяются от фона уровнем среднего арифметического без использования величины среднеквадратичного отклонения.

В дальнейшем необходимо провести детальные исследования, которые позволят установить для каждого из полей специфику проявления межблоковых зон, отличающихся: 1) кинематическим типом, рангом и степенью активности; 2) свойствами заполнителя зон и вмещающего их субстрата; 3) особенностями влияния внешних факторов (например, планетарного характера). Сопоставление результатов работ подобного типа позволит уточнить предложенные в статье обобщенные модели проявления межблоковых зон в отдельных геолого-геофизических полях (рис. 17, 20, 21). Это повысит эффективность применения методического комплекса для выделения межблоковых зон в регионах, характеризующихся недостаточной обнаженностью горных пород.

Ключевые слова: межблоковая зона, разломы, блоки, иерархия, трансект, геолого-геофизические методы, Восточная Сибирь, Байкальский рифт.

\section{ОГЛАВЛЕНИЕ}

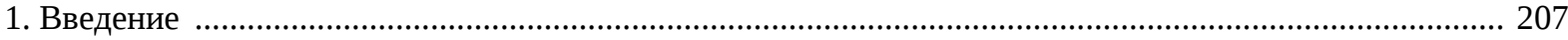

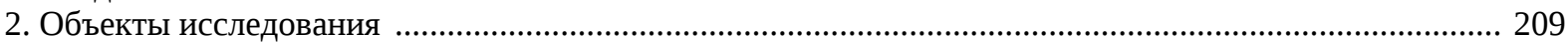

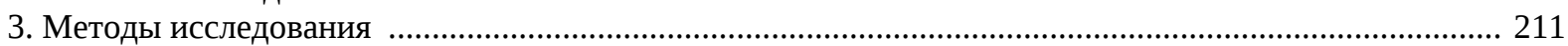

4. Результаты комплексных исследований по трансекту Шертой - Красный Чикой ............................. 213

4.1. Результаты геолого-геофизических исследований межблоковых зон на

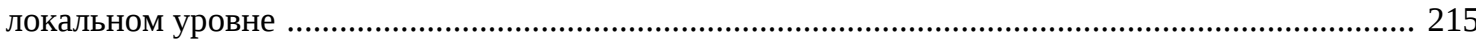

4.2. Результаты геолого-геофизических исследований межблоковых зон на региональном уровне

.3. Результаты геолого-геофизических исследований межблоковых зон на трансрегиональном уровне

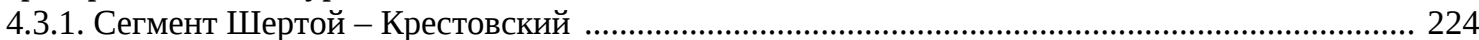

4.3.2. Сегмент Западный берег - Восточный берег .............................................................. 230

4.3.3. Сегмент Кудара - Тарбагатай ................................................................................... 236

4.3.4. Сегмент Тарбагатай - Красный Чикой …....................................................................... 239

4.4. Межблоковые зоны глобального уровня, выделяющиеся по комплексу геолого-геофизических признаков на трансекте Шертой - Красный Чикой ................................ 243

5. Иерархия межблоковых зон юга Восточной Сибири в соответствии с результатами комплексной интерпретации геолого-геофизических данных по трансекту Шертой - Красный Чикой

5.1. Характер проявления межблоковых зон юга Восточной Сибири в геофизических,

гидрогеологических и морфотектонических признаках

5.2. Байкальский рифт в структуре межблоковых зон юга Восточной Сибири ................................... 257

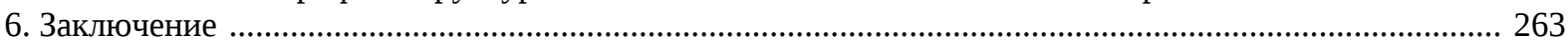

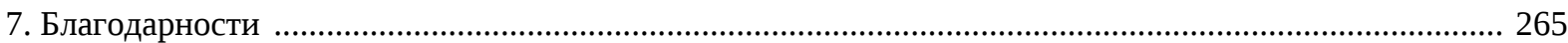

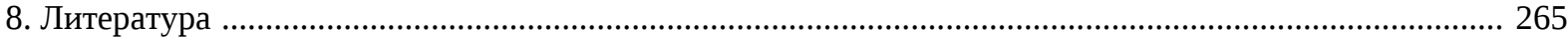




\section{1. ВВЕДЕНИЕ}

Зонно-блоковая структура литосферы представляет собой иерархически организованную систему относительно стабильных блоков и ограничивающих их подвижных зон, которые отличаются высокой дислоцированностью геологического субстрата вследствие перемещений по разломам и сопутствующего складкообразования. Выделение и изучение зонно-блоковой делимости литосферы представляет современное направление исследований, в основе которого лежат результаты работ Л.И. Красного, М.А. Садовского [Krasny, 1984; Sadovsky et al., 1987] и других исследователей. Зонно-блоковая модель делимости твердой оболочки Земли, с одной стороны, учитывает представления тектонистов о блоковом (дискретном) строении литосферы, а с другой - подчеркивает ее принадлежность к реальным физическим телам, фундаментальным свойством которых, согласно законам механики, является структурированность на разных масштабных уровнях.

В настоящее время представления разных специалистов о каждом из двух главных элементов структуры литосферы (блоки и зоны) отличаются друг от друга. Наибольшие разногласия характерны для понимания межблоковых зон, которые в литературе обозначаются различными терминами (деформационная, деструктивная, контактная, мобильная, разломная и др.), а по поперечным размерам считаются малыми [Glasko, Rantsman, 1995; Kostyuchenko et al., 2002; Shebalin et al., 2002; Kurlenya et al., 2005; Kocharyan et al., 2010; and others] либо, наоборот, имеют по отношению к блокам значимую или даже значительную ширину [Krasny, 1984; Sherman et al., 1999; Seminsky, 2001; Seminskii, 2008; Gol'din, 2002; Jacobi, 2002; Viruete et al., 2002; Gatinsky, Rundquist, 2004; Gatinsky et al., 2005, 2007; Makarov, 2007; Sherman, 2012; and others]. Это связано с многообразием проявлений межблоковых зон, которые в тектоническом отношении могут представлять вытянутые области высокой концентрации разломов, зоны повышенной трещиноватости, полосы проявления тектонитов и пр. Кроме того, межблоковая зона иногда внешне по-разному проявляется на отдельных участках вдоль ее простирания, а также в зависимости от стадии эволюционного развития. Очевидно, что отличия будут усиливаться у зон, относящихся к разным масштабным рангам и генетическим типам, а также формирующихся в условиях неравномерного внешнего воздействия, под влиянием структурно-вещественных неоднородностей коры и на ее разных глубинных уровнях.

В связи с вышеизложенным одним из эффективных подходов к исследованию межблоковых зон является комплексное геолого-геофизическое изучение их тектонотипов как характерных представителей группы объектов с аналогичным внутренним строением. Особенно показательны в этом отношении зарубежные исследования межблоковых зон, выраженных круп- ными разломными системами [Unsworth et al., 1997; Schulz, Evans, 2000; Janssen et al., 2002; Weber et al., 2009; Mishra, 2011; and others]. Результаты этих работ представляют добротную основу для выявления в других регионах специфики строения и развития межблоковых структур, формирующихся при растяжении, сжатии и сдвиге. Приращение объема знаний, полученных в ходе реализации такого подхода, позволит создать в дальнейшем обобщение по межблоковым зонам литосферы в целом, в рамках которого будут выделены наиболее общие закономерности их строения, развития и взаимоотношений друг с другом.

В России одним из хорошо изученных в геодинамическом отношении объектов является Байкальский рифт, который представляет собой центральный сегмент одноименной рифтовой зоны, формирующийся в настоящее время в условиях растяжения на границе Сибирского и Забайкальского блоков литосферы (рис. 1). Особенности его строения и развития представлены в серии обобщающих публикаций [Logachev, Florensov, 1977; Sherman, 1977; Gornostaev et al., 1970; Zamaraev et al., 1979; Krylov et al., 1981; Logachev, 1984; Golubev, 1988, 2007; Lysak, 1988; Popov, 1989; Sherman, Dneprovsky, 1989; Logachev, 1992, 2003; Ufimtsev, 1992; Logatchev, Zorin, 1992; Rasskazov, 1993; Mats, 1993; Melnikov et al., 1994; Petit et al., 1996; San'kov et al., 1997, 2009, 2011; Levi et al., 1997a, 1997b; Ruzhich, 1997; Delvaux et al., 1995; 1997; Solonenko et al., 1997; Mel'nikova, Radziminovich, 1998; Lesne et al., 1998; Berdichevsky et al., 1999; Duchkov et al., 1999; Mats et al., 2001; Polyansky, 2002; Suvorov et al., 2002; ten Brink, Taylor, 2002; Calais et al., 2003; Rezanov et al., 2004; Zorin, Turutanov, 2005; Petit, Deverchere, 2006; Mordvinova et al., 2007; Yakovlev et al., 2007; Lunina et al., 2009; Seminsky, 2009; Radziminovich, 2010; and others], из которых, в частности, следует, что, несмотря на относительно хорошую изученность, мнения специалистов по отдельным чертам строения этой крупной межблоковой структуры (поперечные размеры, взаимоотношения элементов, история развития и пр.) зачастую существенно расходятся. В этом плане целесообразно попытаться изучить Байкальский рифт с единых позиций тектонофизики о зонно-блоковом строении литосферы. Подобное исследование подразумевает проведение в его пределах комплекса геолого-геофизических исследований с их распространением на смежные одноранговые элементы делимости, которыми на юге Восточной Сибири являются Сибирский и Забайкальский блоки литосферы. Это, с учетом необходимости реализации методического комплекса в разных масштабах, может быть корректно проведено только на примере отдельных пересечений (трансектов). Таким образом, главные задачи исследования:

1) выявить зонно-блоковую структуру земной коры юга Восточной Сибири на основе тектонофизического анализа результатов геолого-геофизических работ, 


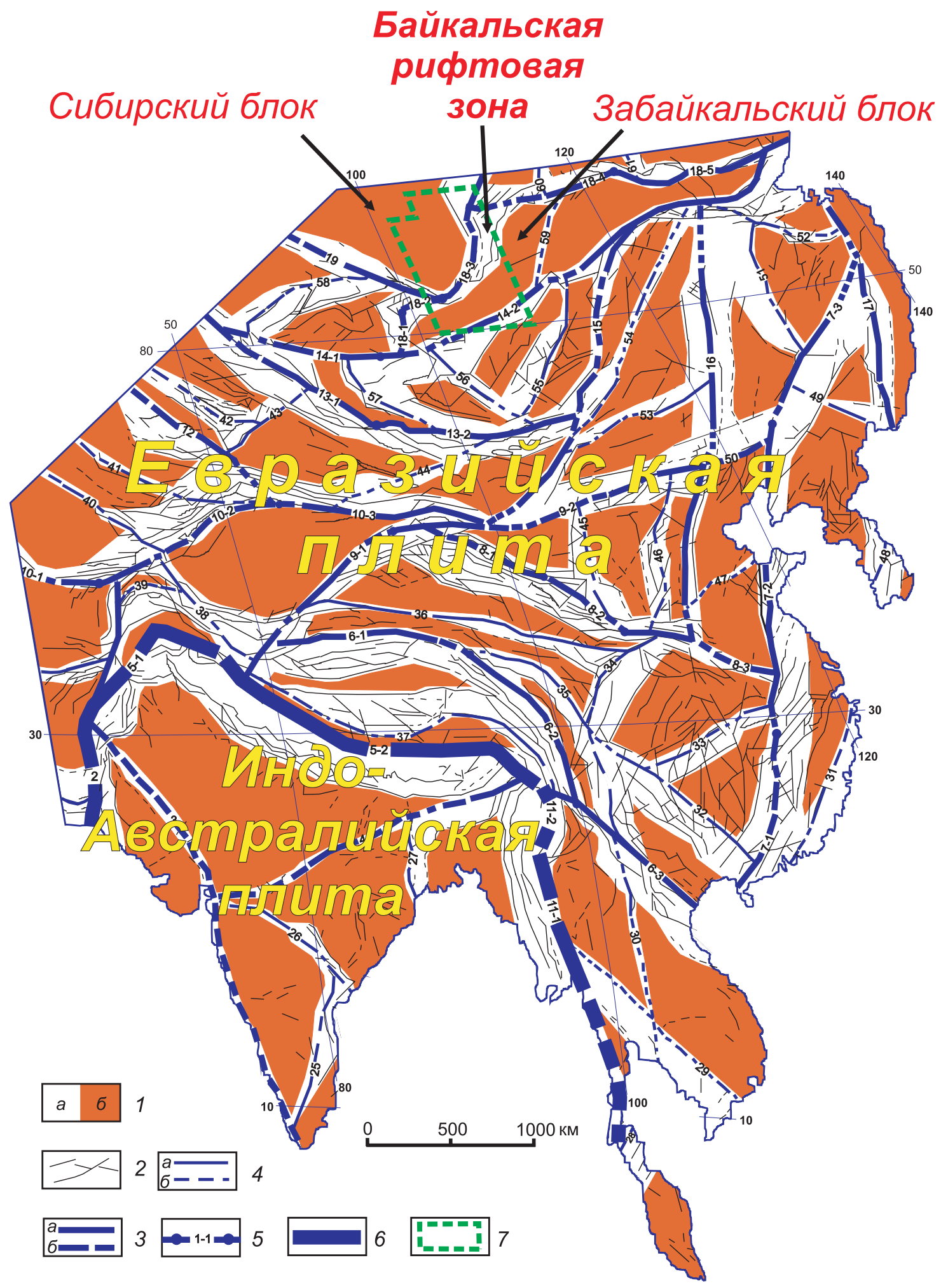

Рис. 1. Схема зонно-блоковой структуры литосферы Центральной Азии [Seminsky, 2001].

1 - площади, занимаемые деструктивными зонами (а) и блоками (б); 2 - разломы по [Khain, 1984]; 3, 4 - магистральные сместители межблоковых зон II (3) и III (4) уровней иерархии, совпадающие (а) и несовпадающие (б) с разломами; 5 - индексация межблоковых зон и их сегментов; 6 - магистральные сместители межблоковой зоны I уровня иерархии; 7 - участок детальных исследований зонно-блоковой структуры земной коры на юге Восточной Сибири (рис. 2).

Fig. 1. A scheme of the zone-block structure of the lithosphere in Central Asia [Seminsky, 2001].

1 - interblock zones (a) and blocks (б); 2 - faults as per [Khain, 1984]; 3, 4 - major fault planes in interblock zones of the 2nd (3) and 3rd (4) hierarchic levels which coincide (a) and do not coincide (b) with faults; 5 - indexation of interblock zones and their segments; 6 - major fault planes in the interblock zone of the $I$ hierarchic level; 7 - site of detailed studies of the zone-block structure of the crust in the southern regions of East Siberia (Fig. 2). 
проведенных в четырех разных масштабах для трансекта (Шертой - Красный Чикой), пересекающего Забайкальский блок, Байкальский рифт и краевую часть Сибирского кратона;

2) уточнить некоторые важные детали строения Байкальской межблоковой зоны путем применения на трансекте Шертой - Красный Чикой некоторых новых видов исследования (например, эманационная съемка) и реализации ранее применявшихся методов в более крупном масштабе (например, магнитотеллурические зондирования);

3) исследовать проявление межблоковых зон в различных геолого-геофизических полях и установить наиболее общие особенности их строения, а также закономерности иерархических и пространственных взаимоотношений на примере земной коры юга Восточной Сибири.

\section{2. ОБЪЕКТЫ ИССЛЕДОВАНИЯ}

В качестве разноранговых представителей подвижных зон взаимодействия плит и блоков в литературе чаще всего фигурируют межплитные границы, разломные системы и разломные зоны разного масштабного ранга. Межплитные границы, как известно, являются зонами контактирования литосферных плит, характеризующимися высокой тектонической активностью, которая проявляется в перемещениях по разломам, сопровождающихся сейсмичностью. Разломные системы являются зонами повышенной концентрации разломов, интегральное перемещение по которым обеспечивает чистые растяжение, сдвиг или сжатие земной коры [Park, 1997]. Разломные зоны, согласно тектонофизической трактовке [Sherman et al., 1983; Seminsky, 2003], представляют не только полосу распространения тектонитов магистрального сместителя (разрыв 1го порядка), но и существенно больший по размерам объем горных пород, в котором имеют место генетически связанные с его формированием пластические и разрывные деформации. Выделяются три дизъюнктивные стадии развития внутренней структуры разломных зон, обусловленные спецификой деформационного поведения участка земной коры под воздействием внешних сил [Seminsky, 2003, 2012]. Разлом на ранней стадии развития - это широкая зона распространения нескольких систем сравнительно мелких разнотипных, но парагенетически связанных разрывов 2-го порядка. Разлом на поздней стадии развития выражен сравнительно узкой зоной ветвящихся, преимущественно однотипных нарушений 2-го порядка, характеризующихся резко неравномерным распределением в продольном направлении: широкие области проявления относительно мелких разрывов чередуются с участками, где зона выражена практически единственным крупным сместителем. Разлом на стадии полного разрушения представлен узкой зоной, где имеет место единый магистральный сместитель и сравнительно мелкие вторичные разрывы оперения, приуроченные главным образом к изгибам его плоскости. В геологической трактовке тектонические нарушения второй и третьей стадий развития являются, соответственно, сложно и более просто построенными разломами, а дизъюнктивы первой стадии развития, как правило, называются зонами повышенной трещиноватости или зонами с высокой плотностью разрывов более крупного масштабного ранга («зоны разломов»). Таким образом, активными в разломной зоне на ранних стадиях являются несколько крупных разрывов (разлом рассредоточенного вида по [Gzovsky, 1963]), а на завершающей стадии - главным образом магистральный сместитель (разлом сосредоточенного вида по [Gzovsky, 1963]).

Главным при формировании межблоковых зон разного масштабного ранга является тектонический фактор. Лишь на уровне межплитных границ дополнительное динамическое воздействие оказывает вещество мантии, поднимающееся к поверхности. Таким образом, характер деструкции в пределах разноранговых межблоковых зон определяется главным образом относительными движениями различных по размерам блоков литосферы. Следовательно, формирование их внутренней структуры должно осуществляться по аналогичным законам механики разрушения, различаясь характером реологического поведения субстрата на разных уровнях иерархии. В связи с этим известные из тектонофизики закономерности разломообразования (стадийность, упорядоченная неравномерность нарушенности субстрата, парагенетические соотношения между разрывами 2-го порядка и др.) были применены для интерпретации разнородных данных, полученных в ходе полевых геолого-геофизических исследований. Реализация такого тектонофизического подхода дала возможность выявить общие закономерности проявления в полях различной природы межблоковых зон, относящихся к существенно разным уровням иерархии в зонно-блоковой структуре литосферы одного из тектонически активных регионов Центральной Азии.

На юге Восточной Сибири удобным для исследования межблоковых структур, проявляющихся в виде разноранговых разломных зон, разломных систем и межплитной границы, является трансект Шертой Красный Чикой, протягивающийся в направлении С3-ЮВ на 500 км. Его положение показано на схеме зонно-блоковой структуры Прибайкалья и смежных регионов (рис. 2). Главным критерием ее построения было выделение межблоковых зон по сгущению спрямленных элементов рельефа (линеаментов), обычно отражающих в геодинамически активных регионах положение разломов, развивавшихся в неоген-четвертичное время. Как следствие, построенная схема соответствует этому периоду, что было подтверждено в итоге комплексных исследований по трансекту Шертой - Красный Чикой. Геолого-геофизические работы проводились в четырех различных масштабах и были 

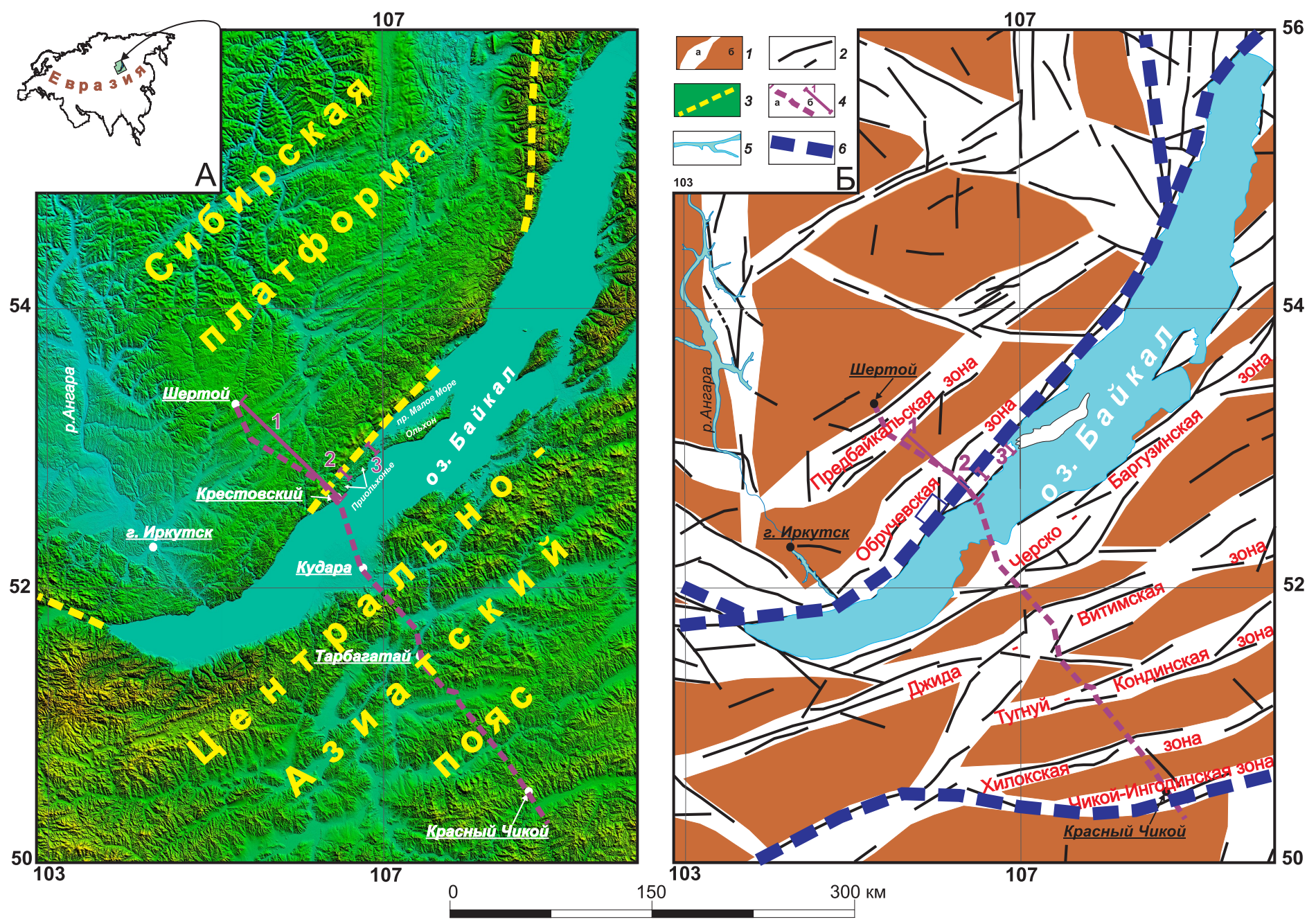

Рис. 2. Трехмерная модель рельефа (А) и построенная на ее основе схема зонно-блоковой структуры земной коры (Б) Прибайкалья и Западного Забайкалья.

1 - межблоковые зоны (а) и блоки (б); 2 - разломы, отчетливо выраженные линеаментами рельефа; 3 - краевой шов Сибирской платформы; 4 - линии транссекта (а) и менее протяженных геолого-геофизических профилей (б); 5 - гидросеть; 6 - границы крупных блоков согласно рис. 1.

Fig. 2. The $3 \mathrm{D}$ topography model $(A)$ and the corresponding scheme of the zone-block structure of the crust $(\bar{D})$ in the Pribaikalie and the Western Transbaikalie.

1 - interblock zones (a) and blocks (б); 2 - faults that are clearly topographically marked; 3 - the marginal suture of the Siberian platform; 4 lines of the transect (a) and shorter geological and geophysical profiles (б); 5 - hydrological network; 6 - boundaries of large blocks according to Fig. 1.

ориентированы на изучение тектонотипов перечисленных выше разновидностей межблоковых зон.

На глобальном уровне трансект пересекает главные элементы поперечного сечения, характерные для межплитной границы Байкальского рифта (периферийные прогибы, плечи, рифтовую долину), а также разноранговые межблоковые зоны северо-восточного простирания. Это позволяет считать, что закономерности, выявленные при исследовании трансекта для центральной части рифта, в первом приближении справедливы и для его флангов. Работы осуществлялись по отдельным сегментам (пос. Шертой-мыс Крестов- ский, Западный берег - Восточный берег, с. Кудара с. Тарбагатай, с. Тарбагатай - с. Красный Чикой) в разные годы; материалы исследований затем были объединены на графиках и разрезах, соответствующих трансекту в целом. На трансрегиональном уровне в пределах трансекта были исследованы внутренняя структура и специфика геофизических полей, связанных с разломными системами, активными на современном этапе тектогенеза. К ним, прежде всего, относится Обручевская система, представляющая западное плечо рифта (рис. 2, Б, профиль 1: сегмент трансекта Шертой-Крестовский), а также межблоковые зоны 
аналогичного иерархического уровня, которые пересекают трансект Шертой - Красный Чикой на его более юго-восточных сегментах: Черско-Баргузинская (или Восточно-Байкальская), Джида-Витимская, Чикой-Ингодинская и др. В рассматриваемом масштабе исследований точки измерений располагались вдоль сегментов трансекта на расстояниях от 2.5 до 5.0 км друг от друга.

На региональном уровне в пределах трансекта исследовались разломные зоны - тектонотипы крупных сбросов, определяющих внутреннюю структуру разломных систем, которые представляют собой западное и восточное плечи рифта в непосредственной близости от котловины оз. Байкал. Это Прихребтовая, Приморская и Морская разломные зоны для Обручевской системы, а также Дельтовая и Бортовая разломные зоны для Черско-Баргузинской системы. С целью достижения необходимой детальности исследований шаг между точками измерений на соответствующих отрезках трансекта сокращался до первых сотен метров. Так, он был равен 250 м на юго-восточном участке профиля 1 (рис. 2, Б), пересекающем Приморскую разломную зону, которая в Западном Прибайкалье отчетливо выражена Бугульдейско-Чернорудским грабеном [Dombrovskaya, 1973; Mats, 1993]. На территории Приольхонья, где прошла трасса трансекта (рис. 2, А), эта структура образована собственно Приморским и Тырганским сбросами, строение которых представляло предмет наиболее детальных исследований.

На локальном уровне в качестве типичных представителей небольших разломных зон было изучено 19 активных тектонических нарушений, проявленных тектонитами в обнажениях горных пород и/или уступами в рельефе Приольхонья. Они исследованы вдоль детальных пересечений (шаг между пунктами геофизических измерений от 5.0 до 2.5 м), располагающихся на отдельных участках в пределах основного трансекта (рис. 2, профиль 1), а также еще двух линий, располагающихся в центральной (рис. 2, профиль 2) и северовосточной (рис. 2, профиль 3) частях Приольхонья. Фактические данные, полученные для небольших межблоковых зон рассматриваемой территории, иллюстрируются в статье на примере одного из сбросов, который отчетливо проявлен в структурных и геоморфологических признаках на мысе Онтхой (рис. 2, A, профиль 3).

Таким образом, комплексные исследования межблоковых зон проводились на юге Восточной Сибири в четырех масштабах, отличаясь друг от друга по степени детальности на 1-2 порядка. Собранный фактический материал обеспечил возможность изучения тектонического строения и геофизических полей, характерных для уровней межплитной границы (Байкальская рифтовая зона), разломных систем (например, Обручевской), а также крупных (например, Приморская) и мелких (например, сброс на м. Онтхой) разломных зон северо-восточного простирания, т.е. позволил получить целостное представление об иерархии межблоковых зон в верхней части коры обширного региона. При этом исследования вдоль трансекта Шертой - Красный Чикой позволили изучить проявление зонно-блоковой структуры на территориях со слабой (юг Сибирского кратона), умеренной (Забайкальский блок) и высокой (Байкальский рифт) современной тектонической активностью. Не случайно многие региональные пересечения тектонических структур юга Восточной Сибири проводились вдоль протяженных профилей с близкими по положению маршрутами [Krylov et al., 1981; Zorin et al., 1994, 2002; Yungsheng et al., 1996;]. Данные предшественников использовались в ходе обсуждения результатов наших исследований, которые в ряде случаев отличались высокой детальностью (например, электро- и магниторазведка, магнитотеллурические зондирования), постановкой некоторых новых видов работ (например, радон-тороновая съемка) или использованием новейшего оборудования (например, для МТЗ).

\section{3. МЕТОДЫ ИССЛЕДОВАНИЯ}

Полный перечень методов, использованных коллективом специалистов для решения поставленных задач, включал изучение разрывов структурно-геологическими методами, морфотектонический анализ рельефа на основе полевых геоморфологических наблюдений и дешифрирования дистанционных материалов, магнитную съемку, электроразведку методами естественного электрического поля (ЕП) и электропрофилирования (ЭП), магнитотеллурические зондирования (МТЗ), гидрогеохимическое опробование водопроявлений и эманационную съемку. Выбранные методы позволили оценить характер нарушенности земной коры разрывами, определяющими внутреннее строение зон активного взаимодействия блоков.

Геолого-структурные исследования проводились в соответствии с методом спецкартирования [Seminsky, 1994] и его последующими разработками [Seminsky, Burzunova, 2007; Seminsky, Cheremnykh, 2011]. Основу метода составляет парагенетический анализ массовых замеров повсеместно распространенной трещиноватости, а также структурных материалов по проявлению более крупных разрывных нарушений земной коры. В итоге вдоль профилей были изучены вариации плотности трещин (для 1 кв. или пог. м массива), выделены и охарактеризованы активные в новейшее время разломы, включая реконструкцию полей напряжений для этапов наиболее масштабных перемещений. Как следствие, в пределах профилей выделялись интенсивно нарушенные интервалы, соответствующие межблоковым зонам, и относительно слабодислоцированные блоки, что являлось результатом геолого-структурного анализа, важным для интерпретации геофизических данных. 
Морфотектонический анализ рельефа проводился путем сопоставления гипсометрических профилей и графиков вариаций параметра плотности линеаментов $(D$ - количество спрямленных элементов рельефа в

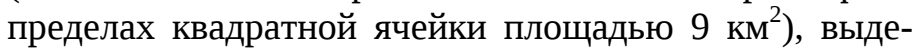
ленных на изучаемых участках с использованием известных методических приемов. Как правило, впадинам и пониженным формам рельефа соответствуют зоны наибольшей нарушенности массива горных пород, а участкам с максимальными отметками - места с меньшей плотностью линеаментов. Таким образом, на гипсометрически пониженных и наиболее нарушенных участках горного массива в наиболее общем случае профили должны пересекать подвижные зоны, по которым контактируют массивные блоки земной коры.

Радон-тороновая съемка проводилась по отработанной для условий Прибайкалья методике [Seminsky, Bobrov, 2009], позволяющей измерять прибором РРА01M-03 для каждой пробы подпочвенного воздуха

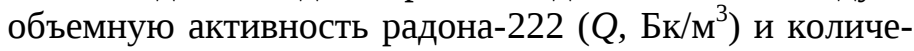
ство распадов торона в рабочей камере радиометра $(N)$. Кроме того, величина параметра $Q$ измерялась, согласно стандартной методике [The Method..., 2004], в поверхностных водопроявлениях, расположенных вблизи изучаемых профилей. В соответствии с предыдущим опытом [Seminsky, Bobrov, 2009] распределение концентраций радона и торона в первом приближении согласуется друг с другом и прямо связано со степенью нарушенности горных пород разрывами. Однако имеют место отклонения от данной закономерности, связанные с неоднородным строением разломных зон, а также слабой проницаемостью участков локализации разломных сместителей, выполненных глинкой трения или перекрытых тонкодисперсными осадками. Это вносит неопределенность в выделение границ межблоковых зон как участков с высокими значениями параметров $Q$ и $N$, хотя само поле газовых эманаций является наиболее значимым для характеристики активных в настоящее время дизъюнктивных структур земной коры.

Гидрогеологические исследования базировались на результатах опробования подземных вод в нескольких десятках точек, которые располагались в непосредственной близости от изученных профилей. Дополнение этих данных материалами Государственной гидрогеологической съемки (м-б 1:200000) позволило получить для северо-западного сегмента трансекта (Шертой Крестовский) представительную сеть из 46 пунктов наблюдения. Этот сегмент был опорным для гидрогеологических исследований, результаты которых заверялись на отдельных участках юго-восточной половины трансекта, где проводилось дополнительное опробование водопроявлений (18 пунктов). Связующим фактором между гидрогеологией и тектонической структурой изучаемого участка земной коры является рельеф, так как его морфология и соответствующие ландшафты во многом обусловливают распределение и гидро- геохимические особенности подземных вод горноскладчатых областей [Pinneker et al., 1968; Stepanov, 1989]. Так, межблоковые зоны, интенсивно нарушенный субстрат которых подвержен глубокому выветриванию с образованием протяженных линейно-эрозионных форм, вблизи поверхности должны характеризоваться специфическими условиями водообмена. В связи с этим особое внимание при обработке данных опробования уделялось анионному составу подземных вод, а точнее - распределению параметра $H$ (сумма сульфат- и хлор-ионов), повышенное значение которого свидетельствует о затрудненных условиях водообмена. Кроме того, субстрат нескольких межблоковых зон локального уровня был изучен на предмет проницаемости для воды при помощи метода наливов в шурфы, согласно стандартной методике, позволяющей определить коэффициент фильтрации $\left(K_{\phi}\right.$, м/сут) [Albul et al., 1979]. Флюидонасыщенность более крупных межблоковых зон изучалась на основе интерпретации данных электроразведки, так как состояние поземной гидросферы в геодинамически активных регионах является определяющим фактором при формировании разнотипных электромагнитных полей. В целом анализ гидрогеологических особенностей трансекта является одним из действенных способов исследования проницаемости и внутренней динамики межблоковых зон.

Съемка методом ЕП выполнялась способом потенциала с использованием неполяризующихся электродов [Semenov, 1980]. Разность потенциалов между опорным и подвижным электродами $(U)$ измерялась с помощью цифрового милливольтметра с входным сопротивлением 10 мОм. При измерении разности потенциалов в диапазоне от нуля до $\pm 200 \mathrm{MB}$ дискретность отсчета оставляла $0.1 \mathrm{mB}$, за пределами этого диапазона - 1 мВ. Ранее [Kozhevnikov, 1998; Kozhevnikov et al., 2004; Kozhevnikov, Tezkan, 1998] эффективность метода была показана на примере выявления разломных зон Прибайкалья, представляющих электронно-проводящие системы, которые в совокупности с вмещающими их ионно-проводящим породами образуют так называемые геобатереи [Bigalke, Grabner, 1997]. Другой причиной аномалий является электрическое поле, возникающее в условиях пересеченного рельефа за счет движения подземных вод [Komarov, 1994]. Таким образом, изучение естественного электрического поля является полезным для выделения в Прибайкалье древних, но активизированных в позднекайнозойское время разломов, которые, с одной стороны, представлены проводящим субстратом, а с другой - выражены депрессиями в рельефе.

Электропрофилирование проводилось с использованием двух установок (А40M20N40B и A100B10M10N); в обоих случаях глубинность исследования составляла первые десятки метров. Для измерения разности потенциалов в приемной и силы тока в питающей линии использовался электронный авто- 
компенсатор АЭ-72. По результатам этих измерений рассчитывалось кажущееся удельное электрическое сопротивление $\left(\rho_{\kappa}\right)$. Минимальные значения данного параметра свидетельствуют о наличии сульфидной и графитовой минерализации, обводненности отдельных участков геологического разреза или его представленности выветрелыми породами. Как следствие, метод электропрофилирования является эффективным для выделения близповерхностных разломов, в зонах динамического влияния которых в той или иной степени присутствуют отмеченные явления.

Магнитная съемка с измерением модуля полного вектора магнитной индукции $(T)$ выполнялась протонным магнитометром ММП-203. Геомагнитное поле отражает преимущественно минеральный состав горных пород и слабо зависит от степени нарушенности массива, поэтому при картировании межблоковых зон данные магниторазведки отличаются наибольшей неоднозначностью интерпретации. Тем не менее во многих случаях субстрат разломных зон вследствие активного проявления магматических и динамометаморфических процессов отличается от окружающего массива горных пород, в т.ч. и магнитными свойствами. Это, в совокупности с экспрессностью реализации метода, явилось причиной для его включения в комплекс работ по исследованию межблоковых зон, пересекаемых трансектом Шертой - Красный Чикой.

Магнитотеллурические зондирования в диапазоне периодов 0.003-10000 с выполялись с применением современной технологии V5 System-2000 и использованием аппаратуры «MTU-5» компании «Phoenix Geophysics» (Канада). Исследования отличались от работ предшественников высокой детальностью с шагом зондирований от 5.0 до 2.5 км. Для обработки полевых материалов использовалось программное обеспечение «Phoenix Geophysics». 1D и 2D инверсия данных MT3 выполнена с помощью программного комплекса «LineInterMT». Описываемый вид исследований является одним из важных составляющих методического комплекса, так как позволяет практически в любых природных обстановках изучать разрез от первых сотен метров до глубин в десятки километров. Он эффективен для выделения нарушенных участков земной коры, которые в связи с флюидизацией маркируются областями низких сопротивлений, что однозначно было показано, например, для крупных межблоковых зон разломного типа [Berdichevskii et al., 1996; Berdichevsky et al., 1999; Unsworth et al., 1999; Ben-Zion, Sammis, 2003; Unsworth, Bedrosian, 2004; Maercklin et al., 2005].

Эффективность охарактеризованного выше методического комплекса обеспечивается сочетанием прямых приемов картирования разломов с косвенными, основанными на повышенной проницаемости разломных зон для магмы и флюидов. Его важным преимуществом является высокая производительность работ, позволившая быстро сформировать банк данных, характеризующих распределение разнотипных полей вдоль трансекта Шертой - Красный Чикой и небольших пересечений межблоковых зон Приольхонья. Комплекс представленных выше методов, реализованных на отдельно взятом профиле, варьировался в зависимости от специфики конкретной межблоковой зоны (ранга, особенностей проявления на местности и пр.). Однако во всех случаях он включал геолого-структурные, морфотектонические, эманационные и электроразведочные исследования (СЭП, ЕП и/или МТЗ), что позволило получить информацию о степени и характере нарушенности земной коры, а затем в ходе ее тектонофизической интерпретации выявить границы и особенности строения межблоковых зон.

Следует отметить, что не всегда измерения параметров разных полей осуществлялись в одних и тех же точках профилей из-за технических сложностей реализации отдельных видов работ. Для равноценного анализа пространственных вариаций разнотипных полей более детальные первичные измерения (рис. 3) осреднялись в окне, размер которого соответствовал одному из четырех масштабов исследования. В некоторых случаях графики, необходимые для сравнительного анализа, строились для трасс изучаемых профилей по полосовидным картам распределения рассматриваемого параметра в изолиниях (например, плотность линеаментов или распределение гидрогеологических показателей).

Попытка выполнить прямую корреляцию параметров, полученных при первичных измерениях или посредством осреднения, не привела к выявлению устойчивых зависимостей между ними. Как следствие, основным способом анализа было сопоставление характера изменчивости разнотипных полей вдоль профилей. При этом выделение связанных с межблоковыми зонами аномалий каждого поля (включая поле плотности разрывов и линеаментов) независимо от его природы осуществлялось по единой методике: аномальная зона трассировалась величинами, большими или меньшими (в полях разного типа), чем среднее по выборке значение рассматриваемого параметра. Отказ от использования величины среднеквадратичного отклонения (б), часто применяемой для выделения аномалий, обусловлен результатами поисковых исследований, проведенных на материалах радоновой съемки [Seminsky, Demberel, 2013]. Они показали, что в большинстве анализируемых случаев однозначно выраженные в структурных и геоморфологических признаках сместители не попадают в границы аномалий, выявленных при уровне фона, соответствующем величине $Q_{c p}+\sigma$ и даже $Q_{c p}+\sigma / 2$.

\section{4. РЕЗУЛЬТАТЫ КОМПЛЕКСНЫХ ИССЛЕДОВАНИЙ ПО ТРАНСЕКТУ ШЕРТОЙ - КРАСНЫЙ ЧИКОЙ}

Ниже последовательно рассматриваются материалы геолого-геофизических исследований межблоковых 

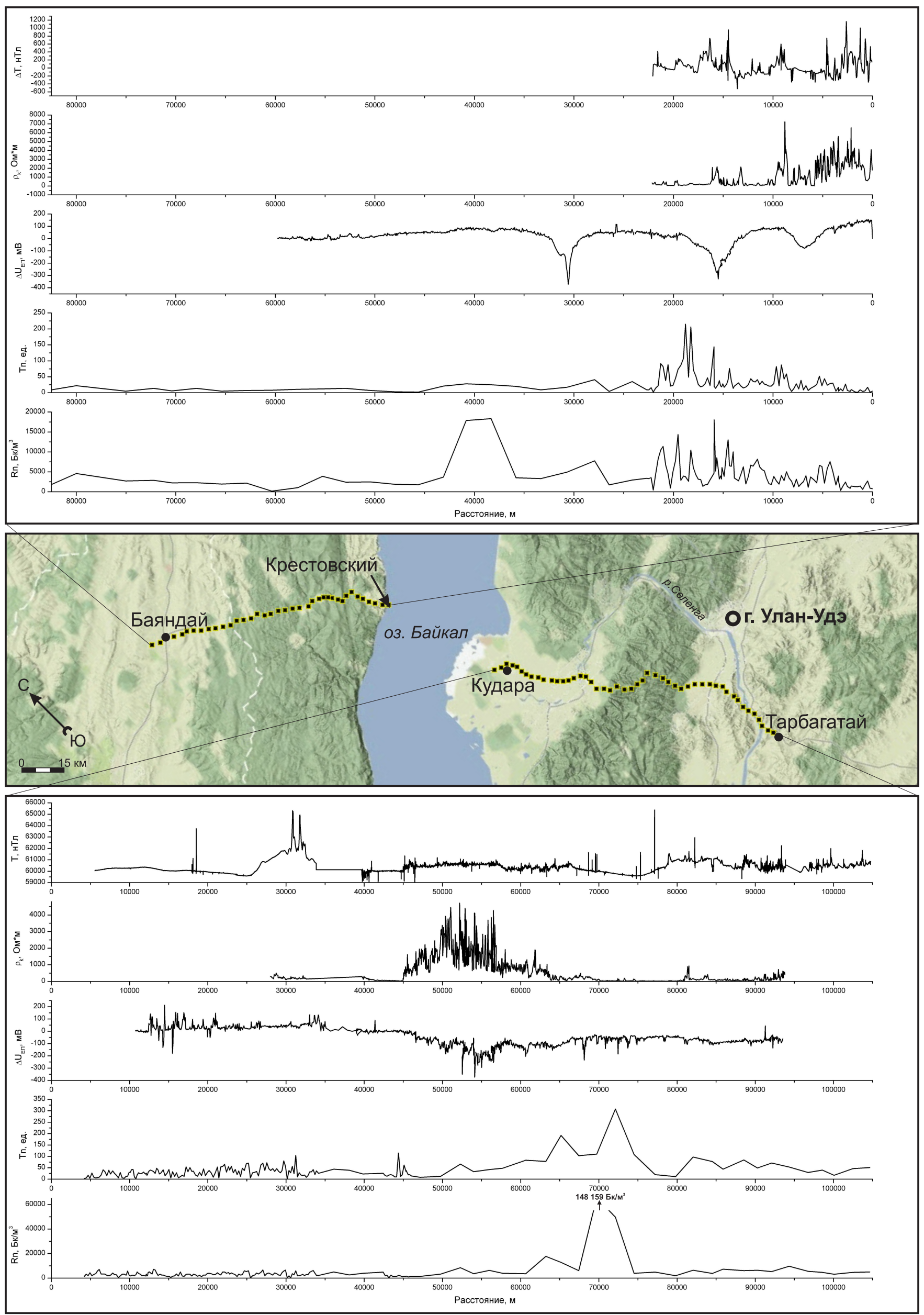
Рис. 3. Первичные графики геофизических полей, измеренных вдоль двух сегментов трансекта Шертой - Крестовский (вверху) и Кудара - Тарбагатай (внизу), положение которых показано на трехмерной модели рельефа (в центре).

$\Delta T$ (вверху), $T$ (внизу) - приращение модуля (вверху) и модуль (внизу) полного вектора магнитной индукции; $\rho_{\kappa}-$ кажущееся удельное электрическое сопротивление; $\Delta U_{E \Pi}$ - потенциал естественного электрического поля; $T n$ - количество распадов торона в камере радиометра; $R n$ - объемная активность радона.

Fig. 3. Initial curves of geophysical fields measured along two segments of the Shertoy - Krestovsky (top) and the Kudara - Tarbagatay (bottom) transect. Positions of the two segments are shown in 3D topography model (centre).

Magnetic induction module: $\Delta T$ (top) - increment, $T$ (bottom) - total; $\rho_{\kappa}$ - apparent resistivity; $\Delta U_{E \Pi}$ - potential of the natural electric field; $T n$ number of thoron decays in the radiometer chamber; $R n$ - soil-radon activity.

зон земной коры, соответствующие локальному, региональному, трансрегиональному и глобальному уровням иерархии.

\section{1. РЕЗУЛЬТАТЫ ГЕОЛОГО-ГЕОФИЗИЧЕСКИХ ИССЛЕДОВАНИЙ МЕЖБЛОКОВЫХ ЗОН НА ЛОКАЛЬНОМ УРОВНЕ}

Фактические данные, полученные в Прибайкалье при детальном изучении серии межблоковых зон локального уровня, иллюстрируются на примере зоны небольшого разлома, пересекающего мыс Онтхой в северо-западной части Приольхонья (рис. 4). Они включают геоморфологические (топоплан) и структурно-геологические (разрез, фотодокументация разломных сместителей, графики вариаций плотности трещин, круговые диаграммы трещиноватости и полей напряжений) материалы. Здесь же представлены результаты радон-тороновой съемки, изучения проницаемости горного массива для воды, а также магнитои электроразведки в виде графиков изменения параметров $Q, N, K_{\phi}, T, \rho_{\text {к }}, D$ по одним и тем же профилям. Рис. 4 иллюстрирует описанные ниже особенности выраженности разломных зон Прибайкалья в разнотипных признаках.

Строение разломных зон. Геолого-структурные и геоморфологические наблюдения, проведенные на 19 изученных участках, в целом подтвердили результаты исследований разломов Приольхонья, опубликованные ранее [Pavlovsky, 1969; Pleshanov, Chernov, 1968; Florensov, 1977; Kashik, 1978; Zamaraev et al., 1979; Pleshanov, Romazina, 1981; Kuklei, 1985; Lobatskaya, 1987; Mazukabzov, Sizykh, 1987; Sherman, Dneprovsky, 1989; Logachev, 1994; Seminsky, 1994; 2003; Levi et al., 1997a; Delvaux et al., 1997; Mats et al., 2001; Lunina et al., 2002; Cheremnykh, Markovtseva, 2007; Seminsky, Cheremnykh, 2011; u dp.]. Учитывая полученные нами данные, следует отметить следующее.

Тектонические нарушения отчетливо проявлены в рельефе Приольхонского плато и в структурных признаках - по его обрывистым берегам. В геоморфологическом отношении это ложбины (рис. 4, Б) или небольшие уступы, представляющие борта более крупных впадин. У уреза воды оз. Байкал разломные зоны, как правило, выделяются нишами и гротами, образо- вавшимися вследствие предпочтительного разрушения и вымывания ослабленных пород разломной зоны в процессе волноприбойной деятельности.

Согласно структурным наблюдениям, породы Приольхонья, принадлежащие к древним полихронным метаморфическим комплексам краевых поднятий Центрально-Азиатского складчатого пояса, в целом интенсивно нарушены трещинами (рис. 4, A-3, B-1). Их плотность в среднем составляет примерно 10 тр./пог.м (20 тр./ $\mathrm{M}^{2}$ ); на ее фоне разломные сместители выделяются значениями, достигающими в среднем 25 тр./пог.м (35-40 тр./м²) (рис. 4, B-2). Ширина зон определяется рангом тектонического нарушения, но при прочих равных условиях зависит от степени зрелости внутренней структуры. Зачастую в разрезе зона представлена единичным сместителем (стадия полного разрушения) или полосой с высокой плотностью трещин, которые имеют существенную протяженность, но не проявляются видимыми смещениями (ранняя дизъюнктивная стадия разломообразования). Однако наиболее часто разлом выражен широкой зоной повышенной трещиноватости с двумя - тремя сместителями, один из которых, судя по мощности тектонитов, является главным (поздняя дизъюнктивная стадия разломообразования). Между этими сместителями, как правило, располагаются узкие блоки достаточно массивных пород, где значение параметра $D$ может соответствовать фону (рис. 4, B-2).

Внешне хаотическая сеть трещин, характерная для изученных разломных зон (рис. $4, A-3)$, образована наложением отдельных парагенезисов, возникших в разные этапы активизации тектонических движений (рис. 4, A-1, A-2). Из нескольких выделяющихся подобным образом этапов наиболее выраженными в породах Приольхонья являются раннепалеозойское сжатие в направлении С3-ЮВ, аналогичным образом ориентированное современное растяжение, а также предшествовавший рифтовой эпохе сдвиг с ориентировкой оси сжатия в меридиональном и оси растяжения в широтном направлении. В этих условиях доминирующая в регионе система северо-восточных разломов последовательно активизировалась в виде надвигов и взбросов, левосторонних сдвигов и, наконец, сбросов. Следует отметить, что многие из изученных разломов су- 
A

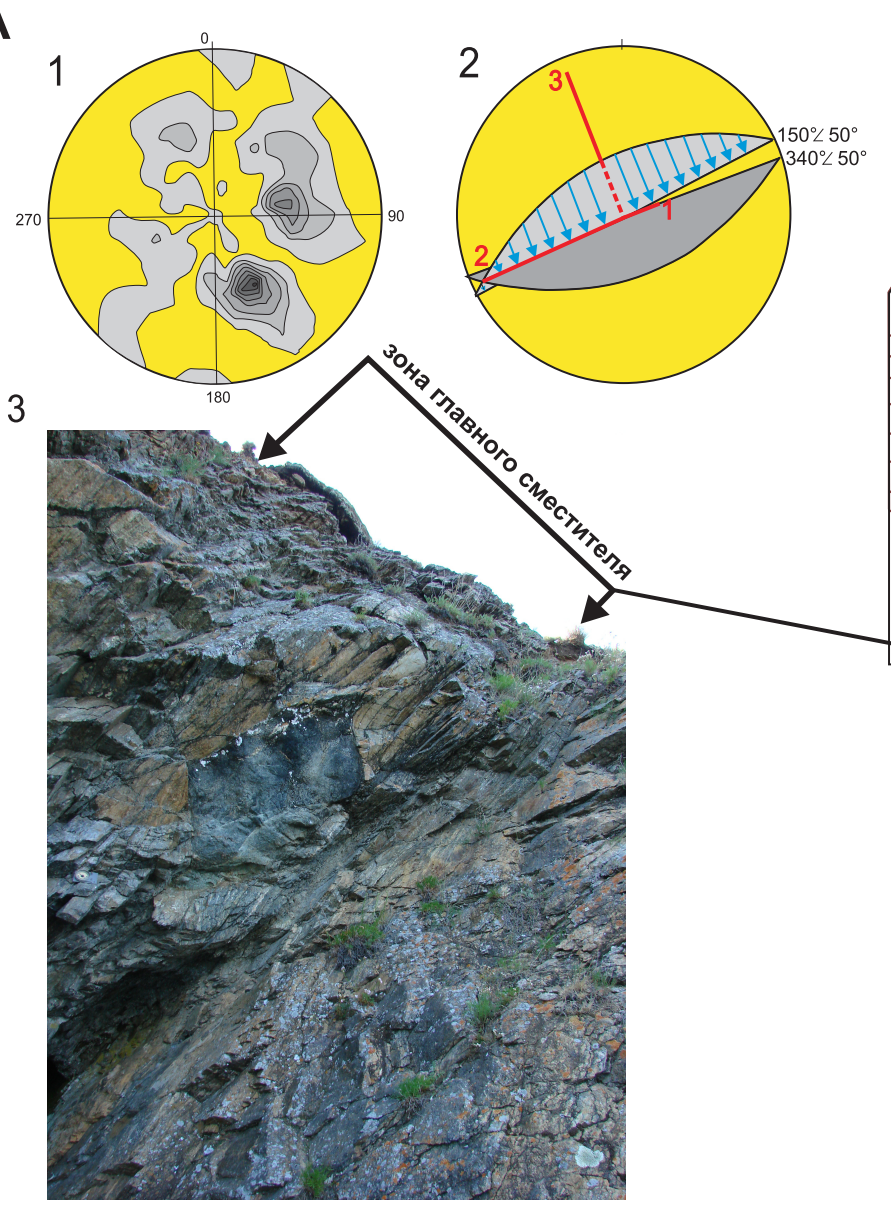

A

$-48071 \stackrel{a=6}{a} \overbrace{3}$

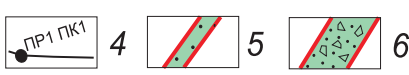

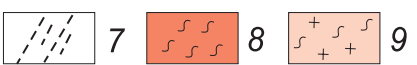

$s_{s^{+} s^{s}} 10 \longrightarrow 112$

I. 13 에 ${ }^{6} N^{15}$

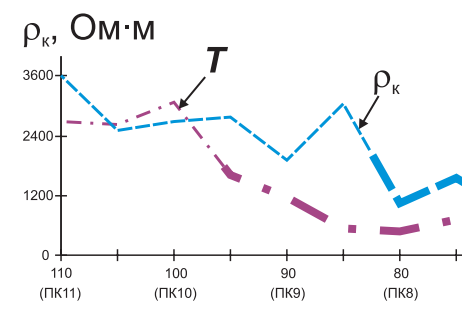

$\rho_{\mathrm{k}}, \mathrm{OM} \cdot \mathrm{M}$

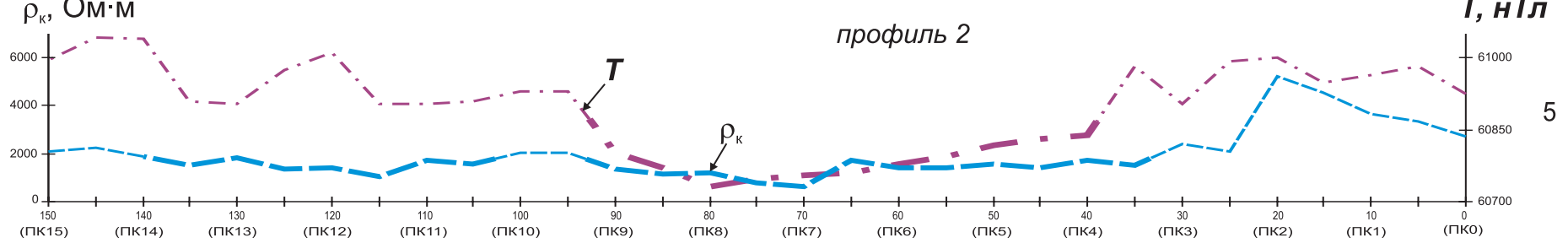

Расстояние, м
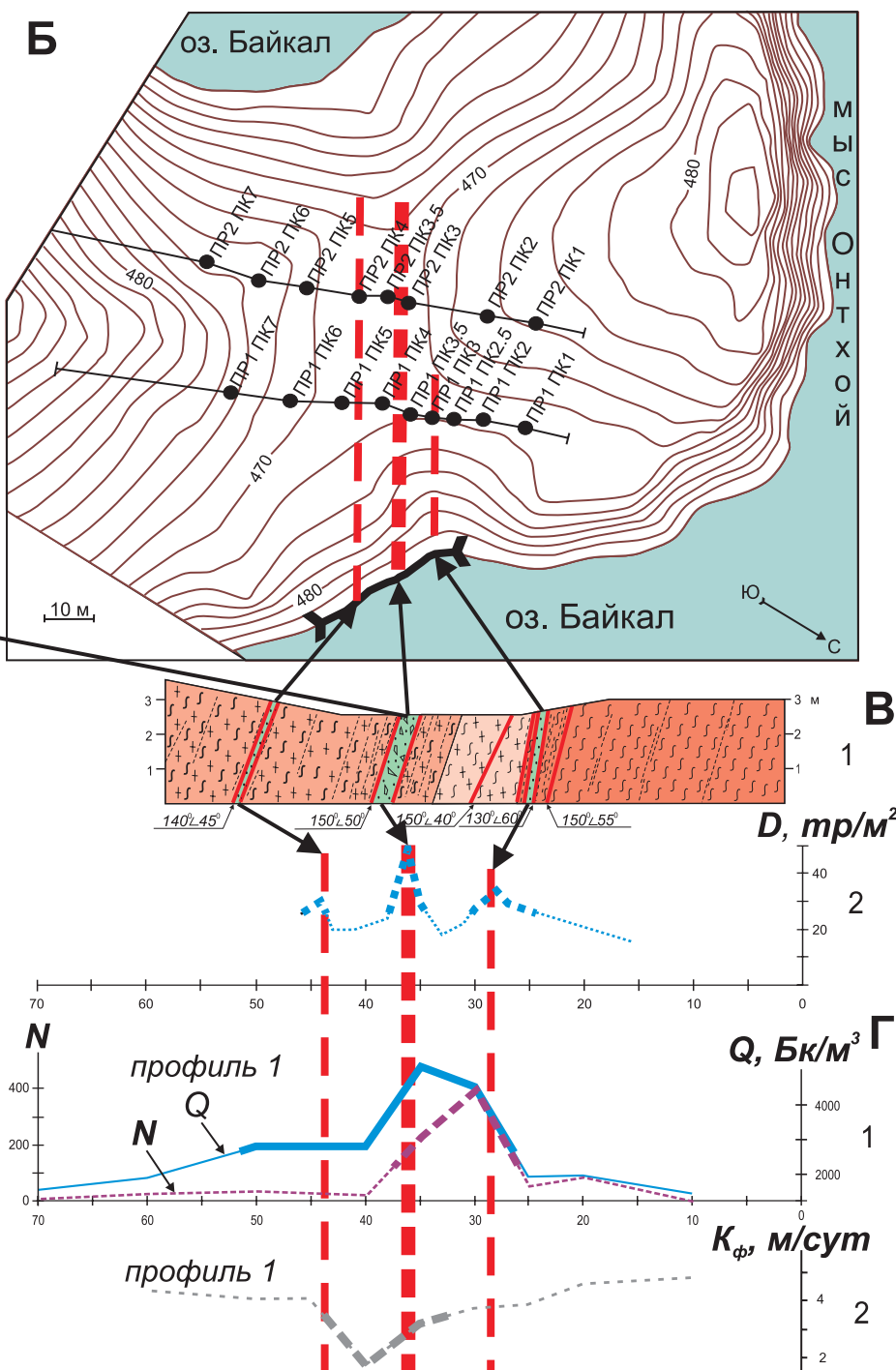

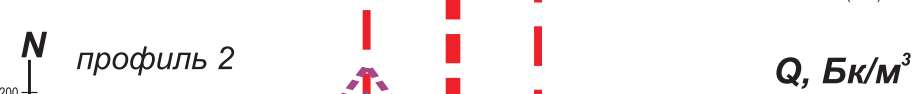

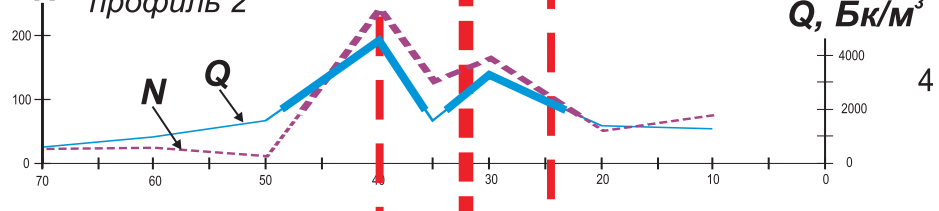

$T, \boldsymbol{H T}$ 
Рис. 4. Результаты профильных геолого-геофизических исследований разломной зоны локального уровня, изученной на мысе Онтхой в Приольхонье.

$A$ - диаграмма трещиноватости (1), решение о поле напряжений (2) и фотография коренного выхода (3), в котором обнажается главный сместитель разломной зоны; $Б$ - расположение геофизических профилей на схеме горизонталей рельефа, построенной для участка исследований при помощи GPS-приемника с шагом между замерами 10 м (данные Е.И. Когута); B - структурно-геологический разрез (1) и график вариаций плотности трещин в $1 \mathrm{~m}^{2}(D)$ коренного выхода (2); $\Gamma$ - объемная активность радона $(Q)$, количество распадов торона $(N)$, кажущееся удельное электрическое сопротивление $\left(\rho_{k}\right)$, полный вектор магнитной индукции $(T)$ и коэффициент фильтрации воды $\left(K_{\phi}\right)$, измеренные вдоль профилей $1(\Gamma, 1-3)$ и $2(\Gamma, 4-5) .1$ - горизонтали рельефа; 2 - главный (а) и второстепенные (б) сместители разломной зоны; 3 - линия структурно-геологических наблюдений вдоль берега; 4 - линии геофизических профилей (индексация пикетов дана для эманационной съемки); 5-6 - второстепенные (5) и главный (6) сместители, представленные разнотипной брекчией дробления; 7 - интенсивно трещиноватые участки; 8 - гнейсы; 9 - гранитогнейсы; 10 - древние милониты; 11-12 - плоскости сопряженных сколов, по которым определялись оси напряжений и направление скольжения (стрелки) по главному сместителю разломной зоны; 13 - оси напряжений (1 - ось сжатия, 2 - промежуточная, 3 - ось растяжения); 14 - диаграмма трещиноватости (100 замеров; уровни - 0.5-1.5-...7,5 \%); 15 - участки графиков с величинами соответствующего параметра, меньшими (а) и большими (б) среднего арифметического значения по профилю.

Fig. 4. Results of geological and geophysical profile studies of the local fault zone located at the Ontkhoy Cape in the Priolkhonie.

$A$ - fracturing diagram (1), stress field solution (2), and photos of the basic rock outcrop (3) with the major fault plane; 5 - positions of geophysical profiles in the topography scheme constructed from GPS data collected in 10-meter intervals (the data are provided by E.I. Kogut); $B$ - the structural cross-section (1), and the curve showing variations in the density of fractures per $1 \mathrm{~m}^{2}$ (D) of the basic rock outcrop (2); $\Gamma$ radon activity $(\mathrm{Q})$, number of thoron decays $(\mathrm{N})$, apparent electric resistivity $\left(\rho_{\mathrm{K}}\right)$, complete vector of magnetic induction (T), and water filtration factor $\left(\mathrm{K}_{\phi}\right)$ which were measured along profiles $(\Gamma, 1-3)$ and $2(\Gamma, 4-5) .1$ - topography horizontal lines; 2 - major (a) and secondary (б) fault planes; 3 - the line of structural observations along the shoreline; 4 - lines of geophysical profiles (indices are given for emanation surveys); 5-6 secondary (5) and major (6) fault planes represented by crush breccias of various types; 7 - intensively fractured areas; 8 - gneiss; 9 - granite gneiss; 10 - ancient mylonite; 11-12 - planes of conjugated joints which were referred to in determinations of stress axes and slip directions (arrows) along the major fault plane; 13 - stress axes ( 1 - compression axis, 2 - transitional axis, 3 - extension axis); 14 - fracturing diagram (100 measurements; levels - 0.5-1.5-...-7.5\%); 15 - segments of curves and values of the corresponding parameter which are smaller (a) and larger (б) than its mean arithmetic value for the profile.

ществовали в земной коре региона до тектонических событий, связанных с перечисленными выше динамическими обстановками. Свойственные последним «рыхлые» тектониты (глинка трения, разломная брекчия) практически повсеместно наследуют мощные выветрелые зоны древних сместителей, которые представлены в обнажениях катаклазитами, милонитами, бластомилонитами и оказались вблизи поверхности в результате длительной истории геологического развития рассматриваемого региона (рис. 4, B-1).

Гидрогеологические особенности. Четыре разломные зоны Приольхонья, приповерхностный субстрат которых изучался на предмет проницаемости для воды при помощи метода наливов в шурфы, выделяются участками минимальных значений коэффициента фильтрации (рис. 4, Г-2). При этом аномально низкие величины $K_{\phi}$ (до $1 \mathrm{M} /$ сут) контролируются положением главного (если судить по ширине зоны тектонитов) сместителя зоны, так как фиксируются непосредственно над ним или, реже, в смежном блоке, что, например, характерно для изученного участка в зоне локального сброса на м. Онтхой. Затруднительная миграция воды в разрывах, представляющих внутреннюю структуру разломной зоны, связана с относительно бо́льшим процентом мелкозернистой фракции, чем это характерно для окружающего массива. Согласно предложенной Н.Н. Масловым [Maslov, Kotov, 1971] классификации грунтов по водопроницаемости, снижение величины $K_{\phi}$ от 5-10 до 1 м/сут при переходе от крыльев зоны к ее приосевой части может свидетель- ствовать о смене скальных трещиноватых пород тонко- и мелкозернистыми грунтами. Очевидной причиной поперечной зональности подобного типа является наличие общей тенденции увеличения нарушенности пород от периферии разломной зоны к оси вследствие механического разрушения при тектонических перемещениях и интенсификации процессов выветривания.

Объемная активность радона. Необходимо отметить, что поле эманаций радона, связанных с разломами Западного Прибайкалья и Центральной Монголии, изучено авторами статьи наиболее детально [Seminsky, Bobrov, 2009; Seminsky, Demberel, 1913]. Это позволяет в данном случае не останавливаться на промежуточных результатах, уделив основное внимание закономерностям отражения межблоковых зон разломного типа в поле объемной активности почвенного радона на локальном уровне исследований.

На каждом из профилей, пересекающих разломные зоны, последние в целом отчетливо фиксируются наибольшими значениями объемной активности радона. Иногда дизъюнктивы выделялись в виде единого максимума с постепенным или ступенчатым повышением параметра $Q$ от периферии к его наибольшему значению в центральной части (рис. $4, \Gamma-1)$. Часто наиболее крупные из сместителей разломной зоны проявляются на участках аномальных значений объемной активности радона в виде локальных экстремумов: максимумов при наличии трещиноватой разломной брекчии (рис. 4, $\Gamma$-4), но чаще - минимумов, поскольку тектонитом является слабопроницаемая для газов глинка 
трения. В то же время проницаемость субстрата является не единственной причиной неравномерности поля почвенного радона над разломными зонами, так как графики вариаций параметра $Q$ и коэффициента фильтрации воды у одних и тех же объектов обычно не совпадают. Увеличенный выход радона при минимуме скорости фильтрации на рассматриваемом участке зоны может объясняться локализацией подвижек по разрывам, в результате которых происходит измельчение субстрата, увеличение свободной поверхности для эманирования и, как следствие, повышение активности радона [Albul et al., 1979].

При чередовании вдоль профиля минимумов и максимумов параметра $Q$ поперечный размер эманационной аномалии (прерывистого типа) оценивался по внешним ограничениям крайних участков аномальных величин объемной активности радона. Установлено, что границы приразломной аномалии радона контролируются границами зоны проявления сместителей и сопутствующей трещиноватости, плотность которой превышает значение, среднее для профиля. Установлено усредненное для всех изученных разломных зон Приольхонья соотношение $M_{D} / M_{Q} \approx 0.7$, где $M_{Q}$ и $M_{D}$ - оценки ширины разломной зоны по размеру участков аномальных значений объемной активности радона и плотности трещин, соответственно.

В целом аномалии почвенного радона над небольшими разломными зонами отличаются пространственной неоднородностью, которая связана с изменчивостью в проницаемости их субстрата. Форма аномалий зависит от структуры разломной зоны, определяющейся стадией ее развития, а также наличия или отсутствия непроницаемого для газа заполнителя (глинка трения, продукты выветривания, перекрывающие осадки). В зависимости от сочетания этих факторов в поперечном сечении аномалий выделяются различные ситуации. В простом случае (незалеченный разлом сосредоточенного типа) имеет место постепенное повышение объемной активности радона от периферии к поверхности смещения. В наиболее сложном случае, т.е. при наличии тонкодисперсного заполнителя и/или системы второстепенных разрывов и блоков с разной проницаемостью, аномалия представлена чередованием участков высоких и низких значений объемной активности радона. Два промежуточных случая дают аналогичную («двугорбую» в разрезе) аномалию с периферийными максимумами и осевым минимумом. Однако в одном из них минимум располагается над главным разломом с глинкой трения, а в другом - над блоком между двумя проницаемыми второстепенными разломами.

Представленные выше закономерности распределения почвенного радона над разломными зонами с известным строением послужили отправным моментом интерпретации данных эманационной съемки, проведенной для тех участков трансекта Шертой - Красный Чикой, на которых структурная ситуация изучена не- достаточно. Однако в регионах со слабой обнаженностью интенсивно нарушенных горных пород такая интерпретация, как было показано выше, не всегда однозначна, что требует привлечения дополнительных методов геофизических исследований для выделения границ межблоковых зон.

Количество распадов торона, измеренное на изученных локальных участках, характеризуется более сложной пространственной изменчивостью по сравнению с объемной активностью радона. Иногда вариации параметра $N$ аналогичны форме изменчивости объемной активности радона на том же профиле (рис. $4, \Gamma-1,4)$. В других случаях графики $N$ и $Q$ в целом подобны при отличии в деталях. Наконец, на некоторых профилях при выделении разломных зон по аномальным значениям обоих параметров обнаруживается несовпадение формы графиков. Иногда их пики приурочены к располагающимся рядом точкам измерений, как это ранее отмечалось предшественниками при изучении наиболее крупных разломов Байкальской рифтовой зоны [Koval et al., 2006]. В других ситуациях выходы радона трассируют главный сместитель, а торона - его крылья. Учитывая, что характер эманаций в обоих случаях определяется проницаемостью субстрата разломной зоны, логично предположить, что несовпадение пространственного распределения эманаций связано с отличием периодов полураспада радона и торона. Поскольку период полураспада торона $\left(\mathrm{T}_{1 / 2}=54.5\right.$ с) в несколько тысяч раз меньше по сравнению с периодом полураспада радона $\left(\mathrm{T}_{1 / 2}=3.8\right.$ сут), более сложное пространственное распределение количества распадов торона отражает близповерхностную ситуацию, для которой степень нарушенности пород, кроме тектонического, зависит и от других факторов (например, приливные явления).

Кажущееся удельное электрическое сопротивление. Изученные разломы выделяются аномалиями $\rho_{\kappa}$, причем, как правило, это аномально низкие значения кажущегося сопротивления (до первых десятков Ом·м). Причиной подобных величин $\rho_{\kappa}$ в разломных зонах является отличие их субстрата от вмещающих пород вследствие интенсивного выветривания древних тектонитов или повышенной обводненности участков с высокой плотностью открытых разрывов. Для изученных сравнительно небольших разломов аномальные участки, выявленные по значениям $Q$ и $\rho_{\text {к }}$ в первом приближении совпадают. Однако размеры приразломных аномалий, выделяемых по распределениям двух рассматриваемых параметров, различны. Рис. 4, $Г$, иллюстрирует случай, когда ширина аномалии $\rho_{\text {к }}$ превышает размер участка аномальных значений $Q$, причем последний занимает краевую часть минимума на графике $\rho_{\text {}}$, центр которого смещен в висячий блок. Вероятной причиной несоответствия является то, что в поле $\rho_{\text {к }}$ отражается крупная зона древнего разлома, тогда как в пределах непротяженного профиля эманационной съемки зафиксирована часть зоны, активизиро- 
ванной на современном этапе рифтогенеза.

Магнитное поле отражает преимущественно минеральный состав горных пород и слабо зависит от степени нарушенности массива. Тем не менее во многих случаях зоны максимумов и минимумов поля $T$ совпадают с участками соответственно повышенных и пониженных значений $\rho_{\mathrm{K}}$ (рис. $4, \Gamma$-3). Хотя причина отмеченной корреляции $\rho_{\mathrm{k}}$ и $T$ в настоящий момент остается невыясненной, тот факт, что разломные зоны Приольхонья, несмотря на «маскирующее» влияние вещественного фактора, находят отражение в геомагнитном поле, не вызывает сомнений.

Применение комплекса экспрессных геологогеофизических методов для изучения небольших разломов Западного Прибайкалья позволило получить уникальную информацию о структуре и физических полях разломных зон земной коры региона, отличающегося многоэтапной историей тектонического развития. Анализ структурных и геофизических данных дал возможность установить, что границы разломных зон отчетливо выделяются в каждом из полей по аномальным, т.е. отличающимся от среднего, значениям характеризующих их параметров. Сопоставление поперечных размеров полученных таким способом аномалий и сравнение на качественном уровне характера выраженности отдельных структурных элементов разломных зон в разных геофизических полях позволили сделать выводы, которые можно считать общими для локального уровня проявления межблоковых зон.

1. Небольшие разломные зоны Прибайкалья представляют сложные, образованные в течение длительной истории тектонического развития региона трехмерные элементы земной коры, которые отчетливо проявляются в особенностях пространственных распределений радона и торона, коэффициента фильтрации, кажущегося удельного электрического сопротивления и модуля полного вектора магнитной индукции. В полях перечисленных параметров разломы выделяются в виде широких аномалий, как правило, имеющих неравномерное строение. Неоднородность распределений обусловливается наличием отдельных сместителей и узких менее нарушенных блоков, т.е. проявлением на локальном уровне зонно-блокового строения земной коры, которое осложняется влиянием нетектонических факторов (вещественный состав горных пород, выветривание, обводненность и др.). Как следствие, детали пространственных распределений геофизических параметров отражают разные особенности внутреннего строения межблоковых зон разломного типа.

2. Наибольшей неоднозначностью в плане структурной интерпретации отличается магнитное поле, поскольку в нем отражается специфическое свойство субстрата, присутствие которого в дислоцированном скальном массиве не является обязательным. Более информативным является поле кажущегося удельного электрического сопротивления, в котором отражаются как структурные, так и вещественные особенности строения земной коры. Аномально низкие значения данного параметра, свойственные разломным зонам у поверхности, не связаны с обводнением, так как характеризуются низкой экспериментально определенной скоростью миграции воды. Они обусловлены повышенной нарушенностью субстрата, связанной с тектоническими подвижками и выветриванием, для которых интенсивность проявления не всегда пространственно совпадает. Как следствие, по аномалиям удельного электрического сопротивления в Приольхонье наиболее отчетливо выделяются широкие интенсивно выветрелые зоны тектонитов, образовавшихся на глубине при масштабных тектонических событиях на докайнозойских этапах развития территории. В их пределах в виде эманационных аномалий проявляются сравнительно узкие полосы интенсивно нарушенных пород, активизированные в ходе кайнозойского рифтогенеза.

3. Наиболее информативными в плане характеристики структуры являются эманации радона, поскольку торон ввиду малого периода полураспада отражает проницаемость преимущественно близповерхностного слоя, которая контролируется в том числе и нетектоническими факторами. Активные разломные зоны находят отчетливое отражение в пространственном распределении радона, так как его концентрация в почвенном воздухе в существенной степени определяется нарушенностью скального массива, разрывами и интенсивностью подвижек в пределах их сетей. Разломы проявляются в виде широких полос аномальных значений объемной активности радона, поперечные размеры которых в Приольхонье примерно в полтора раза превышают ширину зон повышенной трещиноватости, сформировавшихся в результате перемещения крыльев. Радоновые аномалии над разломами демонстрируют ярко выраженную неоднородность: в поперечном профиле выделяется серия локальных максимумов и минимумов, маркирующих положение блоков и отдельных активных сместителей с проницаемыми или непроницаемыми для газа тектонитами. Наличие в разрезе участков интенсивного выветривания пород с высоким содержанием урана или тонкодисперсных осадков осложняет интерпретацию данных эманационной съемки, которая в подобных случаях должна быть дополнена применением других геофизических методов исследования структуры земной коры.

\section{2. РЕЗУЛЬТАТЫ ГЕОЛОГО-ГЕОФИЗИЧЕСКИХ ИССЛЕДОВАНИЙ МЕЖБЛОКОВЫХ ЗОН НА РЕГИОНАЛЬНОМ УРОВНЕ}

Главные черты строения межблоковых структур регионального уровня иллюстрируются ниже на примере Приморской сбросовой зоны. Она является тектонотипом для большинства региональных разломов, пересеченных трансектом Шертой - Красный Чикой, и в связи с этим была исследована полным комплексом геолого-геофизических методов (геолого-структурные и 
геоморфологические наблюдения, ЕП, СЭП, МТЗ, магниторазведка, радон-тороновая съемка и гидрогеохимическое опробование водопроявлений).

Строение разломной зоны. Геолого-структурные и геоморфологические признаки зоны Приморского сброса, выявленные в ходе геолого-геофизических исследований на детально изученном участке трансекта в районе д. Тырган (рис. 5, a), в полной мере отражают особенности строения этого рифтообразующего дизъюнктива, известные из работ предшественников [Pavlovsky, 1969; Dombrovskaya, 1973; Zamaraev et al., 1979; Pleshanov, Romazina, 1981; Lobatskaya, 1987; Sherman, Dneprovsky, 1989; Logachev, 1992; 1994; Mats et al., 2001; Lunina et al., 2002; Seminsky, 2003; Cheremnykh, Markovtseva, 2007; and others]. Это один из выраженных древними тектонитами сегментов краевого шва Сибирской платформы, который не раз активизировался в ходе истории тектонического развития региона. Последние из наиболее значимых интенсивных перемещений блоков вдоль Приморского разлома происходили в раннепалеозойское и кайнозойское время, когда доминирующими динамическими обстановками были, соответственно, сжатие и растяжение в направлении С3-ЮВ.

В ходе кайнозойского рифтообразования Приморский разлом активизировался в качестве одной из ветвей Обручевской системы растяжения с амплитудой вертикального смещения в сотни метров. Ключевым структурным элементом разломной зоны на участке детальных исследований являлся Бугульдейско-Чернорудский грабен шириной 2.5 км, ограниченный с северо-запада собственно Приморским, а с юго-востока Тырганским сбросом (рис. 5, A). Недостаточная обнаженность пород в районе грабена не позволяет детально исследовать его строение при помощи прямых структурных наблюдений. Однако в карьере и подрезках северо-западного борта впадины автодорогой выделяются интенсивно выветрелые породы с высокой плотностью трещин и более крупных разрывов, представляющих осевую часть Приморского разлома. Анализ разрывной сети с использованием тектонофизических методов восстановления поля напряжений [Gzovsky, 1963; Parfenov, 1984; Sherman, Dneprovsky, 1989; Nikolaev, 1992; Seminsky, 1994] позволил реконструировать сбросовые перемещения по разломным плоскостям с элементами залегания $130-150^{\circ} \angle 50-80^{\circ}$, которые имеют на участке исследований преимущественное распространение. В юго-восточном крыле Тырганского разлома зафиксировано противоположное падение разрывов, однако, согласно известным структурным моделям участков активного растяжения земной коры [McCalpin, 1996], можно предположить, что оба разлома наклонены в одну сторону и сочленяются на небольшой глубине. То есть зафиксированное падение в северных румбах разрывов в зоне Тырганского разлома свидетельствует о близповерхностном осложнении оперяющими нарушениями главного сместителя, в целом наклоненного на юго-восток, что подтверждено замерами элементов залегания отдельных сегментов разлома в других участках Приольхонья [Pleshanov, Romazina, 1981; Mats et al., 2001; Seminsky, 2003]. Beроятная причина такого осложнения заключается в том, что на рассматриваемом участке к данному тектоническому нарушению причленяется субперпендикулярный разлом, проявленный в структурных признаках и трассирующийся по спрямленным элементам рельефа вплоть до берега оз. Байкал (рис. 5, A). Центральная часть грабена, судя по изучению небольших коренных выходов, сложена интенсивно трещиноватыми породами, в большей или меньшей степени подверженными выветриванию. Эти наблюдения подтверждают результаты детального геологического картирования, проведенного ранее на некоторых участках с бурением неглубоких скважин [Dombrovskaya, 1973]. Таким образом, кроме бортовых Приморского и Тырганского сбросов региональную разломную зону представляют субпараллельные второстепенные нарушения, которые располагаются внутри грабена, выделяясь участками интенсивной нарушенности за счет повышенной раздробленности и выветривания горных пород.

Кажущееся удельное электрическое сопротивление. На графике вариаций параметра $\rho_{\kappa}$ (рис. 5, E) Приморская разломная зона выделяется участком шириной 3 км, который представлен серией сближенных минимумов и отделен от смежных территорий двумя крупными максимумами значений удельного электрического сопротивления. Величина параметра $\rho_{\kappa}$ в пределах минимумов понижается до первых десятков Ом•м за счет высокого содержания глинистых частиц, образующихся при выветривании интрузивных и метаморфических пород [Palacky, 1989]. Таким образом, материалы СЭП подтверждают и уточняют представленные выше результаты геолого-структурных наблюдений, проведенных в пределах Бугульдейско-Чернорудского грабена на примере отдельных коренных выходов. На изучаемом профиле отчетливо выделяются три широкие зоны интенсивной нарушенности геологического субстрата, две из которых (бортовые) соответствуют собственно Приморскому и Тырганскому сбросам, а третья (центральная) - аналогичному тектоническому нарушению в осевой части грабена. Характерно то, что менее раздробленные блоки, располагающиеся между зонами, уступают последним по поперечному размеру. Данные электропрофилирования, проведенного по трассе рассматриваемого профиля с шагом между пунктами измерения в 50 м, позволили детализировать картину нарушенности субстрата Бугульдейско-Чернорудского грабена. Однако в целом они подтвердили основную закономерность строения Приморской межблоковой зоны в поперечном направлении: чередование интенсивно нарушенных разломных зон и менее раздробленных блоков при общем доминировании первых над вторыми по размеру. 


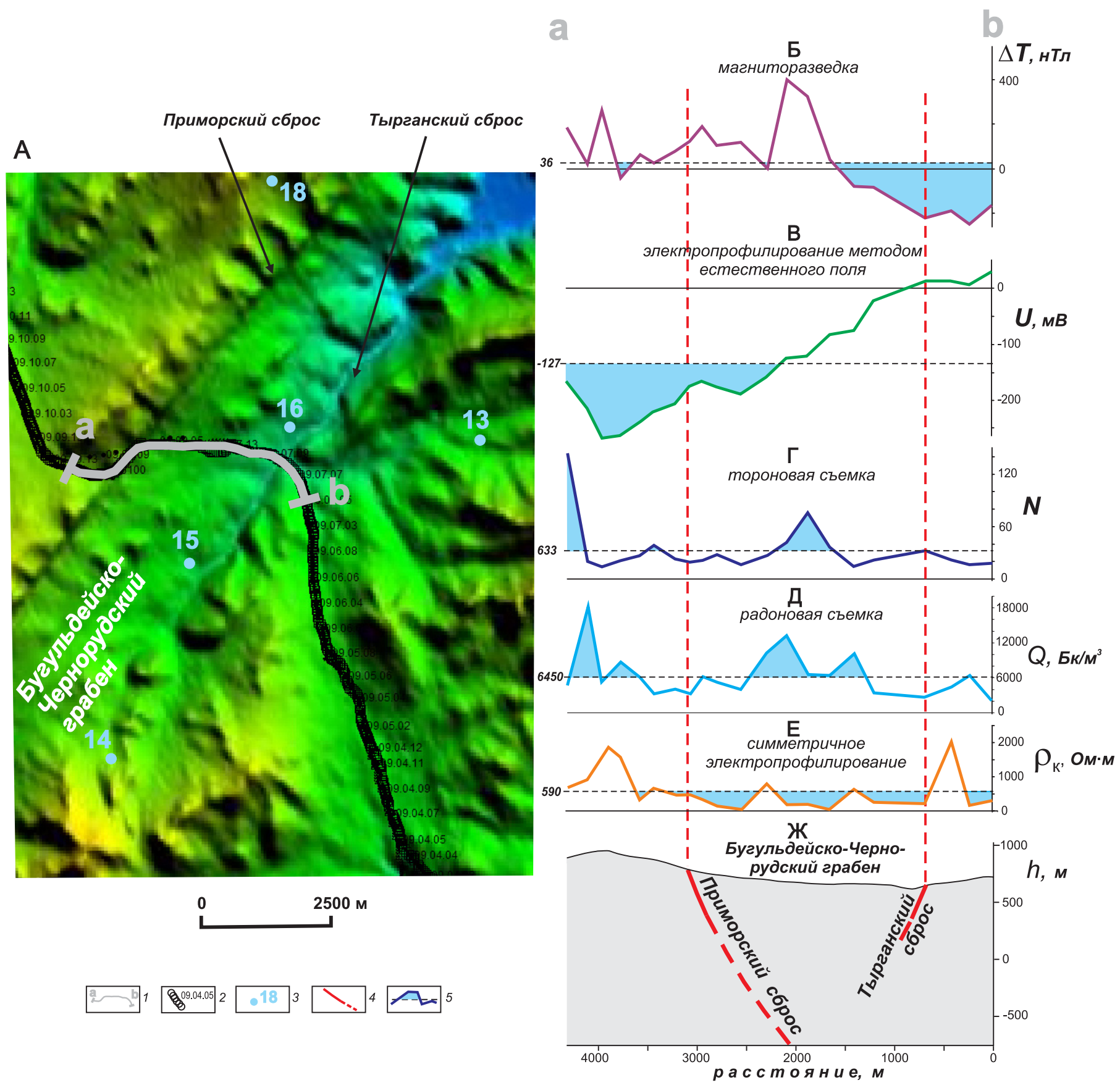

Рис. 5. Результаты геолого-геофизических исследований Приморской региональной межблоковой зоны в Западном Прибайкалье.

$A$ - трехмерная модель рельефа для участка исследований с обозначенными на ней разломными структурами и водопроявлениями, изученными в ходе комплексных работ вдоль профиля a-b; $L-\mathcal{W}$ - графики изменения потенциала естественного электрического поля $(U)$, приращения модуля полного вектора магнитной индукции $(\Delta T)$, количества распадов торона $(N)$, объемной активности радона $(Q)$, кажущегося удельного электрического сопротивления $\left(\rho_{k}\right)$ и абсолютной высоты рельефа $(h)$ вдоль профиля. $l$ - положение профиля $\mathrm{a}-\mathrm{b}$ на трехмерной модели рельефа; 2 - трасса профиля Шертой - Крестовский (индексация приведена для пунктов эманационных измерений; 3 - пункты опробования водопроявлений; 4 - положение в разрезе Приморского и Тырганского сбросов, ограничивающих Бугульдейско-Чернорудский грабен; 5 - области аномальных значений параметров, отличающиеся в большую или меньшую сторону от среднего арифметического (горизонтальный пунктир).

Fig. 5. Results of geological and geophysical studies of the Primorskaya regional interblock zone in the Western Pribaikalie.

$A$ - the 3D topography model for the area under study; it shows faults and water bodies which were comprehensively studied along the a-b profile; $5-\mathcal{K}$ - curves showing changes in the potential of the natural electric field $(U)$, increment of the module of the complete vector of magnetic induction $(\Delta T)$, number of thoron decays $(N)$, radon activity $(Q)$, apparent resistivity $\left(\rho_{\kappa}\right)$, and absolute elevation of the topography $(h)$ along the profile. 1 - position of the a-b profile in the 3D topography model; 2 - route of the Shertoy-Krestovsky profile (indices are shown for emanation measurement sites); 3 - water sampling sites; 4 - positions of the Primorsky and Tyrgansky normal faults in the cross-section; these faults border the Buguldeika-Chernorud graben; 5 - areas of anomalous values of the parameters (smaller or larger than the mean arithmetic value, i.e. horizontal dashed line). 
Объемная активность радона и количество распадов торона. Результаты эманационной съемки, проведенной по пересекающему Приморскую разломную зону профилю, свидетельствуют об интенсивной вариабельности параметров $Q$ и $N$. Наряду с низкими значениями рассматриваемых величин на участках проявления крупных разломных сместителей, в северо-западном крыле Приморского сброса зафиксированы одни из самых высоких для Западного Прибайкалья значения обоих эманационных параметров (рис. 5, Г-Д): первые десятки тысяч Бк/м ${ }^{3}$ для объемной активности радона и первые сотни распадов торона в камере радиометра. Кроме того, вариации рассматриваемых величин вдоль профиля в целом подобны: существенные аномалии радона и торона находятся на северо-западном и центральном участках профиля, тогда как для сместителей собственно Приморского и Тырганского сбросов характерны небольшие значения эманационных параметров. Таким образом, вариации параметров $Q$ и $N$, как и величина $\rho_{\kappa}$, отражают специфику внутреннего строения Приморской разломной зоны, что особенно отчетливо проявляется в поле эманаций радона.

Радоновая аномалия, ассоциирующаяся с Приморской сбросовой зоной, имеет на профиле в районе д. Тырган ширину 4100 м и распространяется на 1200 и 500 м в стороны от бортовых разломов (рис. 5, Д). Она включает пять сближенных отрезков, на которых значение параметра $Q$ превышает среднее арифметическое. Однако эти участки соответствуют не разломам, а блокам, располагающимся между ними. Более высокая проницаемость блоков и участков, располагающихся с внешних сторон крупных бортовых сбросов, объясняется существованием сети открытых трещин, образующихся в горном массиве при активных перемещениях в Приморской разломной зоне. Напротив, отдельные разломы в совокупности с оперяющими их разрывами, представляют собой слабопроницаемые участки, в которых миграция газов затруднена из-за наличия тонкодисперсного заполнителя, которым являются глинка трения и продукты выветривания.

Таким образом, аномалия почвенного радона над Приморской разломной зоной имеет сложный характер. Этот вывод подтверждается материалами электропрофилирования и эманационной съемки, полученными на профиле, который располагался в 3 км югозападнее д. Тырган. Здесь слабонарушенные блоки характеризуются меньшими значениями параметра $Q$, чем разломные зоны грабена, каждый из которых выделяется аномалией с узким минимумом в центральной части, соответствующим главному сместителю. Следовательно, выходу газов в данном случае препятствует только глинка трения, а процессы выветривания развиты в меньшей степени, чем на основном профиле, где их тонкодисперсные продукты существенно осложняют проявление разрывной структуры Приморской разломной зоны в эманационном поле.
Потенциал естественного электрического поля. У северо-западной оконечности изучаемого поля выявлена существенная отрицательная аномалия ЕП (рис. $5, B)$, которая, исходя из опыта предыдущих исследований в Приольхонье [Kozhevnikov, 1998; Kozhevnikov, Tezkan, 1998; Kozhevnikov et al., 2004], по форме и амплитуде может быть обусловлена древним крутопадающим разломом, выполненным графитовой минерализацией. Как видно по положению аномалии на профиле, этим тектоническим нарушением является собственно Приморский разлом, который в качестве составляющего элемента структуры входит в многокилометровую (по ширине проявления древних тектонитов) зону древнего краевого шва Сибирской платформы и был активизирован в процессе кайнозойского рифтинга. Судя по материалам метода ЕП, косвенным подтверждением такой активизации является то, что в районе аномалии график $U$ характеризуется отрицательной корреляцией с рельефом. Вероятно, вклад в аномалию ЕП вносит не только геобатарея, но и электрическое поле, возникающее при фильтрации подземных вод в направлении от высоких отметок рельефа к низким [Komarov, 1994].

Магнитное поле. Вариации параметра $\Delta T$, измеренные на профиле вкрест простирания зоны Приморского разлома (рис. 5,5$)$, не образуют устойчивых взаимосвязей со структурными особенностями рассматриваемого участка земной коры, а также с уже рассмотренными выше геофизическими полями. Исключением в какой-то мере является естественное электрическое поле, вариации которого в первом приближении подобны изменениям параметра $\Delta T$, хотя и противоположны по знаку. Так, зона собственно Приморского разлома, несмотря на частные вариации магнитного поля, в целом выделяется высокими (положительными) значениями величины $\Delta T$ по сравнению с юговосточной частью профиля, где в районе проявления разрывов Тырганской сбросовой зоны имеет место обширный минимум. Это позволяет предполагать, что магнитное поле на рассматриваемом участке, как и распределение величины $U$, в большей степени отражает вещественные свойства древних тектонитов, чем их нарушенность вследствие кайнозойского структурообразования.

Гидрогеологические особенности. Гидрогеохимическое опробование проводилось по стандартной методике и охватило несколько родников, располагающихся в районе д. Тырган (рис. 5, A). Согласно результатам полного химического анализа, проведенного в гидрогеохимической лаборатории Института земной коры СО РАН, все воды классифицируются как магниево-кальциевые, но в зависимости от расположения родников они отличаются по минерализации. Для опробованных вод Приморского хребта, возвышающегося над Бугульдейско-Чернорудской впадиной с северозапада, характерна низкая минерализация $(0.08$ г/дм³), что объясняется значительным количеством атмосфер- 
ных осадков (до 400-500 мм/год), являющихся постоянным источником питания трещинно-грунтовых вод. Воды Приольхонья отличаются большей минерализацией (0.13-0.32 г/дм $\left.{ }^{3}\right)$, так как эта слаборасчлененная территория характеризуется аридным климатом с продолжительным периодом безоблачных дней, малым количеством осадков ( $\approx 160$ мм/год) и частыми разнонаправленными ветрами, не способствующими накоплению снегового покрова. Таким образом, вариации локальных ландшафтно-климатических обстановок в окрестностях изучаемого профиля находят отражение в условиях питания и, как следствие, минерализации подземных вод. Однако более определенные выводы о проявлении межблоковых зон в гидрогеологических особенностях района могут быть сделаны только для структур большего масштабного ранга, у которых размеры областей динамического влияния позволяют привлечь к анализу материалы по необходимому количеству выходов подземных вод.

Подавляющее большинство представленных выше установленных для Приморской разломной зоны закономерностей проявления ее внутренней структуры в разных геолого-геофизических полях свойственно и другим межблоковым зонам регионального уровня, пересеченным трансектом Шертой - Красный Чикой в Прибайкалье. Дельтовая и Бортовая зоны, составляющие внутреннюю структуру Черско-Баргузинской разломной системы (см. рис. 2), также являются дизъюнктивами длительного развития, которые в процессе образования Байкальского рифта активизировались как сбросы и сформировали ступенчатую структуру его юго-восточного плеча. Дизъюнктивы, как правило, проявляются аномалиями изученных параметров, однако только часть из них $\left(h, D, \rho_{\kappa}\right)$ по знаку совпадает с выявленными для Приморской разломной зоны. Причины отсутствия сходных тенденций поведения других параметров различны и важны для решения задач данного исследования.

Распределения объемной активности радона и количества распадов торона оказались практически не информативными для выделения рассматриваемых разломных зон (см. рис. 3): сегмент трансекта Кудара Тарбагатай пересекает их в пределах Усть-Селенгинской депрессии, заполненной тонкодисперсными осадками, которые слабопроницаемы для подземных газов. Потенциал естественного электрического поля на профиле Кудара - Тарбагатай имеет отчетливую обратную связь с рельефом: хребет Хамар-Дабан выделяется минимумом параметра $U$, тогда как с Ингодино-Удинской и Усть-Селенгинской депрессиями ассоциируются максимальные значения потенциала ЕП. Таким образом, в отличие от северо-западного плеча рифта, где активизированные разломы краевого шва Сибирской платформы зачастую выполнены древними проводящими электрический ток тектонитами, естественное поле рассматриваемого участка земной коры образуется в основном под воздействием формирующих кон- трастный рельеф геодинамических факторов. Те же причины могут быть определяющими и в формировании здесь магнитного поля, так как в отличие от собственно Приморского разлома зоны Дельтового, Бортового, Джида-Витимского и других сбросов, пересеченных профилем Кудара - Тарбагатай, отчетливо выделяются участками минимальных значений параметра $T$.

Данные о распределении удельного электрического сопротивления, полученные вдоль профиля Кудара Тарбагатай, подтвердили результаты детальных работ предшественников, проведенных в районе дельты p. Селенги и залива Провал. Н.В Жировой и Г.М. Морозовой с соавторами [Zhirova et al., 1993; Morozova et al., 1999] по материалам электромагнитных зондирований была установлена тесная связь поля электропроводности с тектоническим строением региона, особенностью которого является наличие блоков, разделенных обводненными разрывными нарушениями. Примером отражения дизъюнктивов в поле сопротивлений является сейсмоактивный Дельтовый разлом: широкая (4 км) зона низких сопротивлений (20-50 Ом·м), по которой маркирующие геоэлектрические горизонты сброшены на 4-5 км.

Вышеизложенное позволяет обобщить полученные результаты в виде серии положений, которые отражают закономерности строения и проявления в различных геофизических полях межблоковых зон регионального уровня, развивающихся в Прибайкалье при растяжении земной коры.

1. Межблоковые структуры рассматриваемого уровня иерархии представлены зонами разломов многократной активизации, для которых докайнозойский тектогенез, как правило, был более масштабным по сравнению с позднекайнозойским рифтообразованием. Таким образом, субстратом для формирования изучаемых межблоковых зон Прибайкалья являлись линейно вытянутые участки древних обычно интенсивно выветрелых тектонитов, которые при перемещении блоков в новейшее время целиком или своими контактами послужили неоднородностями, предпочтительными для реализации тектонических напряжений.

2. Процесс активизации разломов северо-восточной ориентировки происходил в режиме растяжения земной коры, что привело к образованию зон интенсивного структурообразования, грабенообразный характер которых отразился впадинами в рельефе Прибайкалья. Пространственная неравномерность деструкции проявилась во внутреннем строении межблоковых зон, у которых в поперечном сечении чередуются сравнительно монолитные блоки земной коры и участки интенсивной нарушенности пород. Последние представляют собой межблоковые структуры локального уровня иерархии, характеризующиеся большими размерами по сравнению со смежными одноранговыми блокаМи.

3. Межблоковые зоны Прибайкалья, изученные 
комплексом методов с соответствующей региональному уровню детальностью, выделяются наиболее интенсивными аномалиями в полях геофизической природы, что косвенно отражает их ведущую роль в процессе деструкции на современном этапе рифтообразования. Значения объемной активности радона и количества распадов торона достигают, соответственно, десятков тысяч Бк/ $\mathrm{M}^{3}$ и десятков единиц, что определяется высокой активностью перемещений блоков, контактирующих по разломам регионального уровня. Вследствие интенсивных процессов разрывообразования, выветривания и обводнения значения кажущегося удельного электрического сопротивления опускаются в межблоковых зонах до единиц Ом·м. Минимумы приращения модуля полного вектора магнитной индукции и потенциала ЕП достигают отрицательных величин в первые сотни, соответственно, нТл и мВ, причем природа магнитного и естественного электрического полей в региональных межблоковых зонах Прибайкалья не является однозначной.

4. Аномалии геофизических полей, связанных с региональными межблоковыми зонами, характеризуются сложной формой даже при рассмотрении только пространственного аспекта их проявления. Внутренняя неравномерность распределения геофизических параметров отражает, прежде всего, структурную неоднородность субстрата, т.е. наличие блоков и зон локального уровня, состояние сети которых обычно изменяется в продольном направлении. Важную роль играет вещественная составляющая, причем для исследованных геофизических полей главным является наличие, тип и пространственное распределение тонкодисперсных продуктов выветривания и рыхлых осадков, как правило, присутствующих в геологическом разрезе разломных зон земной коры. Этот фактор в совокупности с миграцией подземных вод и наличием магнитных пород существенно осложняет характер аномальных распределений геофизических параметров, связанных со структурой разломной зоны.

5. Фактором, повышающим неоднозначность интерпретации связанных с разломными зонами геофизических материалов, является чувствительность определенного поля к разным свойствам объекта исследований, которые иногда находятся друг с другом в сложных взаимоотношениях. Такими свойствами для полей радона и торона являются проницаемость и раздробленность (повышение эманирующей способности) субстрата разломной зоны, для поля кажущегося удельного электрического сопротивления - степень обводнения, выветривания и трещиноватости, для естественного электрического и магнитного полей - наличие «компетентных» (высокопроводящих и/или магнитных) пород и миграция подземных вод. Таким образом, эффективным инструментом исследования структуры межблоковых зон на закрытых для структурного анализа территориях является комплекс охарактеризованных выше методов, направленных на по- лучение достоверных сведений об отдельных особенностях нарушенности массива горных пород, что снижает неоднозначность структурной интерпретации до приемлемого уровня.

\section{3. РЕЗУЛЬТАТЫ ГЕОЛОГО-ГЕОФИЗИЧЕСКИХ ИССЛЕДОВАНИЙ МЕЖБЛОКОВЫХ ЗОН НА ТРАНСРЕГИОНАЛЬНОМ УРОВНЕ}

При проведении комплексных исследований вдоль трансекта Шертой - Красный Чикой было пересечено несколько разломных систем, являющихся представителями межблоковых зон трансрегионального уровня на юге Восточной Сибири. Учитывая разную степень их активности, а также отличия в геологическом строении Забайкалья, Северо-Западного и Юго-Восточного Прибайкалья, полученные результаты рассмотрим ниже отдельно для каждого из трех крупных сегментов трансекта (см. рис. 2, A). При этом северо-западный сегмент (Шертой - Крестовский) будет представлен более подробно, так как на его примере иллюстрируются особенности тектонофизического подхода к интерпретации геолого-геофизических данных, использованные далее при анализе других отрезков трансекта (Западный берег - Восточный берег, Кудара - Тарбагатай, Тарбагатай - Красный Чикой).

\subsection{1. Сегмент Шертой - Крестовский}

Удобное расположение района проведения профильных работ для исследования зоны сочленения Сибирской платформы и Центрально-Азиатского складчатого пояса предопределило его хорошую изученность специалистами разного научного профиля [Florensov, 1960; Zamaraev, 1967; Pinneker et al., 1968; Pavlovsky, 1969; Gornostaev et al., 1970; Pospeev, Mikhalevsky, 1975; Florensov, 1977; Sherman, 1977; Zamaraev et al., 1979; Krylov et al., 1981; Lobatskaya, 1987; Bashkuev u дp., 1989; Popov, 1989; Alexandrov, 1990; Logachev, 1992, 1994, 2003; Ufimtsev, 1992; Rasskazov, 1993; Zorin et al., 1994; Melnikov et al., 1994; Yungsheng et al., 1996; Petit, Deverchere, 1996; Levi et al., 1997a, 1997b; Ruzhich, 1997; Fedorovsky, 1997; Delvaux et al., 1995; 1997; San'kov et al., 1997, 2009, 2011; Solonenko et al., 1997; Kozhevnikov, Tezkan, 1998; Berdichevsky et al., 1999; Duchkov et al., 1999; Perevoznikov, 1999; Mats et al., 2001; Lunina et al., 2002; 2009; Suvorov et al., 2002; ten Brink, Taylor, 2002; Zorin et al., 2002; Seminsky, 2003, 2009; Sklyarova et al., 2004; Sklyarov, 2005; Goldin et al., 2006; Mordvinova et al., 2007; Sklyarov et al., 2007; Yakovlev et al., 2007; Radziminovich, 2010; Seminskii, Radziminovich, 2011; Seminsky, Tugarina, 2011; Sherman, Zlogodukhova, 2011; Seminsky et al., 2012; Epov et al., 2012; and others]. Peзультаты их работ учтены при интерпретации оригинальных материалов, полученных нами в ходе комплексных исследований, которые в большинстве случаев отличает детальность и оптимальное сочетание 
дополняющих друг друга методов профильной съемки. Следует отметить, что подробное описание результатов геолого-геофизических работ, проведенных вдоль описываемого профиля, представлено в недавних публикациях авторского коллектива [Seminsky et al., 2012; Epov et al., 2012; Seminsky, Tugarina, 2011]. Ниже внимание акцентируется на структуре земной коры и геофизических полях, ассоциирующихся с наиболее крупными межблоковыми зонами, которые пересекают профиль Шертой - Крестовский.

Главные вещественно-структурные и морфотектонические особенности рассматриваемого участка земной коры отражены на принципиальном геологическом разрезе (рис. 6, Б) и фрагменте трехмерной модели рельефа Прибайкалья (см. рис. 2, А). На северозападном фланге профиля распространены разнотипные комплексы Сибирского кратона, которые относительно спокойно залегают на периферии сегмента и интенсивно дислоцированы в его центральной части (Прибайкальский краевой прогиб). Здесь они контактируют с полихронными метаморфическими комплексами краевых поднятий Центрально-Азиатского пояса, обнажающимися на поверхности в юго-восточной (приольхонской) части профиля. Контакт происходит по системе разломов краевого платформенного шва (Приморский сегмент), который представлен широкой полосой бластомилонитов и интрузивных проявлений, включая гранитоиды приморского комплекса. Кайнозойская активизация тектонических нарушений на рассматриваемой территории привела к формированию контрастного рельефа. Его характерной особенностью является чередование относительно приподнятых и опущенных форм: Предбайкальский прогиб, Прибайкальский краевой выступ (флексура), Онотское плоское поднятие, Прихребтовая депрессия, Приморское глыбовое поднятие, Бугульдейско-Чернорудская впадина, Приольхонская краевая ступень. Сопоставление гипсометрического профиля и графика вариаций параметра плотности линеаментов $D$ показало (рис. 6,5 , $B)$, что впадинам и пониженным формам рельефа соответствуют зоны наибольшей нарушенности горного массива, а участкам с максимальными отметками места с меньшей плотностью линеаментов. Следовательно, на гипсометрически пониженных и наиболее нарушенных участках горного массива профили пересекают подвижные зоны, по которым контактируют массивные блоки земной коры. Согласно геологоструктурным данным (рис. 6, Б), ключевыми элементами зон являются наклоненные к оз. Байкал сбросы северо-восточного простирания, активные на современной - рифтовой - стадии развития региона: Морской (или Ольхонский) - 0 км профиля, Приморский 15 км профиля, Прихребтовый (Прибайкальский) - 31 км профиля. Исключение составляют участки на северо-западном фланге сегмента Шертой - Крестовский, где, согласно нашим предварительным реконструкциям, в позднекайнозойских отложениях преобладает поле напряжений с ориентировокой оси сжатия в направлении СЗ-ЮВ. В соответствии с геолого-структурными данными западная граница Байкальского рифта пересечена профилем в районе отметки 40 км, что подтверждает взгляды тех исследователей, которые проводят ее по северо-восточным сегментам долин рек Анга, Бугульдейка и Куртун. Этот вывод, в совокупности с уточнением геометрии и типов подвижек по крупным разломам изученного сегмента, является результатом геолого-структурного анализа, важным для последующей интерпретации геофизических данных.

Пространственное распределение и гидрогеохимические особенности проявлений подземных вод в окрестностях сегмента Шертой - Крестовский имеют отчетливую связь с особенностями рельефа изучаемой территории. По существующим классификациям это пресные воды средне- и предгорных районов главным образом поверхностного происхождения [Pinneker et al., 1968; Seminsky, Tugarina, 2011], в анионном составе которых преобладают гидрокарбонат- и сульфатионы, а среди катионов - кальций, магний и, реже, калий и натрий. Областями питания вод являются приподнятые участки рельефа, а разгрузки - располагающиеся между ними линейно вытянутые депрессии. Ввиду того, что последние приурочены к активным разломам, воды в их пределах относятся к классу трещинно-жильных и могут изменяться под воздействием глубинных флюидов, переходя в класс минерализованных, а зачастую и термальных. В позднем неоплейстоцене такая ситуация была характерна для территории Приольхонья, принадлежащего к западному участку исследований, где сравнительно недавно были обнаружены гейзериты [Sklyarova et al., 2004]. Результаты опробования подземных вод в нескольких десятках точек, которые располагались в непосредственной близости от изученного профиля [Seminsky, Tugarina, 2011], дополненные материалами Государственной гидрогеологической съемки (м-б 1:200000), позволили подтвердить упомянутые выше выводы предшественников, а также установить, что определяющую роль в гидрогеологии региона играет тектонический фактор. В качестве отчетливого гидрогеологического рубежа 1-го порядка выступает западная граница Байкальского рифта, которая отделяет слабоминерализованные и пресные воды платформенного блока от ультрапресных и пресных вод горной области. Что же касается более мелких аномалий минерализации, анионного состава и распределения естественных выходов подземных вод, то они приурочены к нарушенным, часто гипсометрически пониженным участкам профиля Шертой - Крестовский. Данная особенность определяется наличием сильновыветрелых пород, а также сочетанием проницаемых и непроницаемых (в случае заполнения глинкой трения) для воды разломных сместителей. Это создает затрудненные условия для водообмена, индикатором которых является повышенное 
K.Zh. Seminsky et al.: Interblock zones in the crust of the southern regions of East Siberia...

A

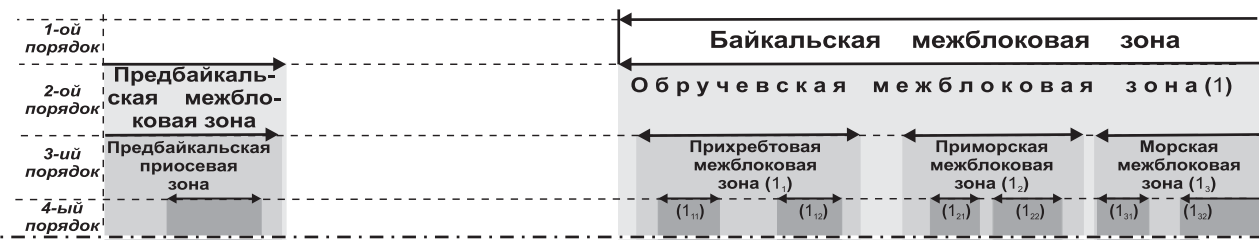

Б

B
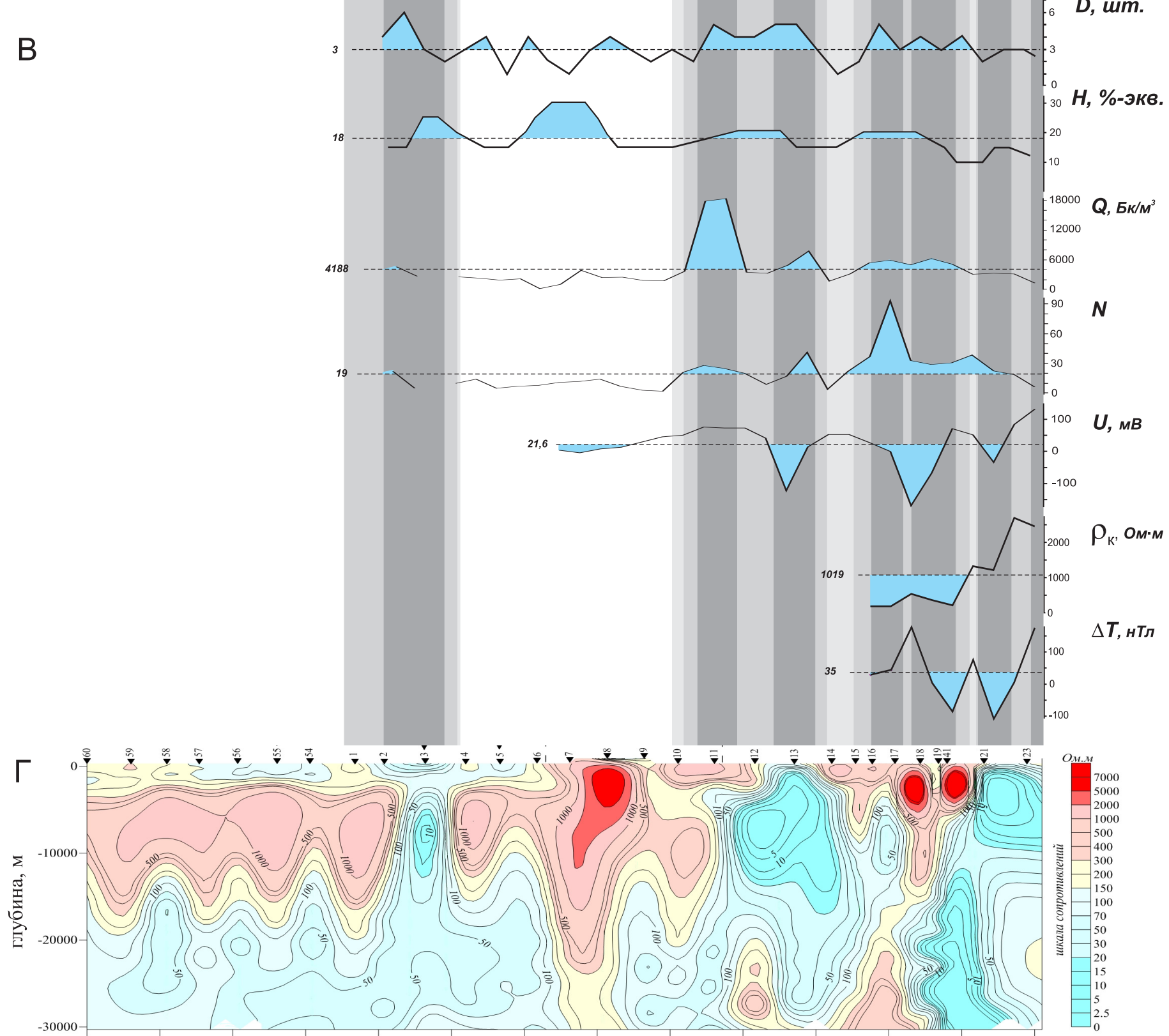

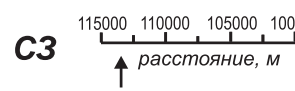

\section{Шертой}

$\because \because 1$

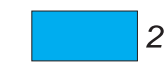

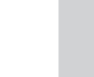

Предбайкальский

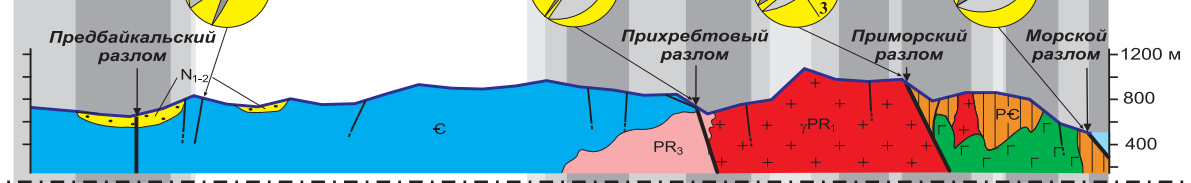

(1)

Прибайкальский
выступ Предбайкальский прогиб

Прихребтовая Бугульдейско-Чер- Байкальская Предбайкальский прогиб 3 ${ }_{3}^{c}$ 
Рис. 6. Результаты геолого-структурных, геофизических, морфотектонических и гидрогеологических исследований на сегменте трансекта Шертой - Крестовский.

$A$ - иерархия межблоковых зон в пределах четырех порядков (границы зон, отмеченные вертикальными полосами с разными оттенками серого цвета, определены по результатам комплексного анализа данных); Б - схематичный геолого-структурный разрез и основные морфоструктурные единицы профиля (на диаграммах - плоскости сместителя разлома (темно-серая) и сопряженной системы разрывов (светло-серая), а также положение осей главных нормальных напряжений: 1 - сжатия, 2 - промежуточная, 3 - растяжения); $B$ - изменения вдоль профиля плотности линеаментов рельефа $(D)$, суммарного количества хлор- и сульфат-ионов в подземных водах $(H)$, объемной активности радона $(Q)$, количества распадов торона $(N)$, потенциала ЕП $(U)$, кажущегося удельного электрического сопротивления $\left(\rho_{k}\right)$ и приращения модуля полного вектора магнитной индукции $(\Delta T) ; \Gamma$ - геоэлектрический разрез, построенный по данным магнитотеллурических зондирований. 1 - аллювиально-озерные отложения (пески, глины, галечники и др.); 2 - породы верхней части осадочного чехла платформы (песчаники, доломиты, известняки, алевролиты, углисто-глинистые сланцы, каменная соль и др.); 3 - породы краевого прогиба платформы (кварциты, метаморфизованные кварцевые порфиры, известняки и др.); 4 - метаморфизованные породы складчатого пояса (разнотипные гнейсы и сланцы, амфиболиты, кристаллические известняки, кварциты и др.); 5-6 - интрузии гранитов (5) или габбро, габбро-диоритов, диоритовых порфиров и др. (6); 7 - крупные и более мелкие разломы; 8 - изолинии значений удельного электрического сопротивления, Ом·м; 9 - пункты МТЗ; 10 - аномальные значения параметров, отличающиеся в большую или меньшую сторону от среднего арифметического (горизонтальный пунктир).

Fig. 6. Results of geological structural, geophysical, morphotectonical and hydrogeological studies of the Shertoy - Krestovsky transect's segment.

$A$ - the hierarchy of interblock zones within the four orders of magnitude (boundaries of the zones, which are marked by vertical stripes in different shades of grey, were determined from results of the complex data analysis); 5 - the schematic structural cross-section, and the main morphology units of the profile. In the diagrams - planes of the fault (dark grey) and the system of conjugated joints (light grey), and positions of axes of the principal normal stresses: 1 - compression, 2 - transitional, 3 - extension; $B$ - along-the-profile changes of density of topography lineaments $(D)$, total number of chloride and sulphate ions in underground water $(H)$, radon activity $(Q)$, number of thoron decays $(N)$, potential of the natural electric field $(U)$, apparent resistivity $\left(\rho_{\kappa}\right)$, and increment of the module of the complete magnetic induction vector $(\Delta T) ; \quad \Gamma-$ geoelectrical cross-section according to magnetotelluric sounding data. 1 - alluvial-lacustrine sediments (sand, clay, gravel etc.); 2 - rocks of the upper part of the sedimentary cover of the platform (sandstone, dolomite, limestone, siltstone, carbonaceous shale, rock salt etc.); 3 - rocks of the marginal trough of the platform (quartzite, metamorphosed quartz porphyrite, limestone etc.); 4 - metamorphosed rocks of the folded belt (gneiss and schist of various types, amphibolite, crystalline limestone, quartzite, etc.); 5-6-intrusions of granite (5) or gabbro, gabbro-diorite, diorite porphyry etc. (6); 7 - large and smaller faults; 8 - isoline of resistivity, ohm.m; 9 - MT sites; 10 - anomalous values of the parameters (smaller or larger than the mean arithmetic values, i. e. - horizontal dashed line).

содержание суммы сульфат- и хлор-ионов (Н) при соответствующем понижении уровня гидрокарбонатиона (рис. 6, В). В отличие от опущенных участков гипсометрически поднятые блоки образуют области питания подземных вод, которые, являясь пресными или ультрапресными (из-за непродолжительного взаимодействия с породой), богаты атмосферным гидрокарбонат-ионом.

Концентрации почвенных радона и торона закономерно изменяются вдоль профиля Шертой - Крестовский, причем их вариации характеризуются определенной аналогией (рис. $6, B$ ). Аномалии параметров $Q$ и $N$ располагаются в юго-восточной части профиля, за исключением приуроченной к интервалу 75-80 км. Они подобны по форме и размеру: аномалия на 40-м км профиля имеет ширину 7 км, на 29-м км профиля 5 км, на 16-м км профиля - около 14 км. Такое распределение газовых эманаций в целом согласуется с характером нарушенности горных пород разрывами, установленным в ходе геолого-структурных и морфотектонических исследований. В рассматриваемой, наиболее дислоцированной, части профиля двум наиболее широким аномалиям плотности линеаментов $D$ соответствуют четыре попарно сближенных участка высоких значений $Q$ и $N$, причем положение локальных минимумов в пределах этих участков совпадает с положением крупных сместителей. В отличие от формы аномалий, их интенсивность в полях радона и торона существенно различается, что, вероятно, обусловлено отличием периодов полураспада радона (3.8 сут) и торона (54.5 с). По радону лучше других выделяется участок, приуроченный к Прихребтовой депрессии, тогда как в поле торона наибольшая интенсивность отмечается в пределах юго-восточной аномалии. Эта аномалия пространственно связана с Приморской региональной межблоковой зоной, неоднородное внутреннее строение которой детально представлено в предыдущем разделе статьи.

Магнитное и электрическое поля были изучены лишь в пределах наиболее нарушенной юго-восточной части профиля Шертой-Крестовский (рис. 6, В). Съемка естественного электрического поля способом потенциала выявила три интервала на профиле с отрицательными аномалиями большой амплитуды. По форме и амплитуде они аналогичны, и, с учетом интерпретации, данной в предыдущем разделе для центральной из них (14 км профиля), эти аномалии отражают положение древних крутопадающих разломных зон, активизированных в позднем кайнозое. Согласно данным электропрофилирования, значительную часть измеренного профиля занимают участки, где кажущееся сопротивление падает до первых десятков Ом·м. Это трудно объяснить исключительно различием электрических свойств минеральной матрицы обнажаю- 
щихся горных пород. Низкие значения $\rho_{\text {к }}$ в значительной мере контролируются интенсивным выветриванием и обводненностью горного массива, нарушенного разрывами, как это было показано ранее для Приморской разломной зоны. Геомагнитное поле отражает преимущественно минеральный состав горных пород и слабо зависит от степени нарушенности массива. Тем не менее на изученной части профиля участки максимумов и минимумов поля $T$ совпадают с отрезками, где были зафиксированы, соответственно, повышенные и пониженные значения $\rho_{\mathrm{\kappa}}$. Причина отмеченной корреляции $\rho_{\text {к }}$ и $T$ в настоящий момент остается невыясненной. Однако тот факт, что магнитное поле, наряду с полями распределения параметров $\rho_{\text {к }}$ и $U$, отчетливо выделяет крупные межблоковые зоны в юговосточной части сегмента Шертой - Крестовский, не вызывает сомнений.

Глубинное строение региона, судя по результатам мелкомасштабных данных предшествующих магнитотеллурических зондирований [Gornostaev et al., 1970; Gornostaev, 1972, 1979; Pospeev, Mikhalevsky, 1975; Pospeev et al., 1978; Popov, 1987, 1989; Glinsky et al., 1991; Berdichevsky et al., 1999], отличается наличием системы проводящих субгоризонтальных слоев и субвертикальных зон флюидной природы. Наиболее значимая из субвертикальных зон имеет ширину 10-20 км и отождествляется со сбросовой разломной системой западного борта Байкальского рифта, уходящей в верхнюю мантию. Кровля внутрикорового слоя с низким удельным электрическим сопротивлением в пределах рассматриваемого региона, судя по цитированным публикациям, располагается на глубине примерно 12 км. Согласно более детальным магнитотеллурическим зондированиям, проведенным нами на профиле Шертой - Крестовский (рис. $6, \Gamma$ ), геоэлектрический разрез здесь по характеру распределения удельного электрического сопротивления (УЭС) делится на две части. Это северо-западный участок, соответствующий Сибирскому кратону, и юго-восточный участок, к которому относятся приграничные платформенные структуры, а также приольхонский фрагмент, представленный древними полихронными метаморфитами (Ольхонская коллизионная зона - по [Fedorovsky, 1997]). Различие этих участков геоэлектрического разреза в большей степени обусловлено не вещественным составом горных пород, а присутствием здесь субвертикальных интенсивно нарушенных и, как следствие, проницаемых для флюидов зон с аномально низким (5-30 Ом·м) сопротивлением. На юго-востоке профиля (интервал 0-40 км) группируется серия таких 3он, тогда как на северо-западе выделяется лишь одна подобная зона. Низкие сопротивления рассматриваемых участков и их секущее положение по отношению к выявленным вещественным комплексам (рис. 6, Б) свидетельствуют, что эти зоны сформировались в результате активных тектонических процессов на границах блоков.
В юго-восточной части профиля положение зон отчетливо соотносится с крупнейшими сбросами, нарушающими западное плечо современного рифта (рис. 6, $Б, \Gamma)$. Из трех зон повышенной проводимости наиболее важной в структурном отношении является первая (08 км профиля), которая на разрезе выделяется в виде широкой области с сопротивлением ниже 10 Ом·м и, видимо, продолжается на юго-восток под акваторию озера. Положение второй крупной зоны в близповерхностной части совпадает с Прихребтовой депрессией (28-33 км профиля). На геоэлектрическом разрезе она проявляется в виде области аномально низких (до 4-7 Ом·м) сопротивлений, ширина которой существенно увеличивается на удалении $\approx 3$ км от поверхности. Третья проводящая зона «просматривается» на глубине в районе измерительных пунктов МТ3-18 и МТ3-19 и характеризуется сопротивлением порядка 30 Ом·м. По масштабу и характеру проявления эта зона уступает двум первым, однако ее пространственное совпадение с зоной Приморского сброса и БугульдейскоЧернорудским грабеном свидетельствует о генетической связи с процессом кайнозойского разломообразования.

Северо-западная часть геоэлектрического разреза отличается преимущественно высокими значениями УЭС, обусловленными составом земной коры в пределах кратонного блока (рис. 6, Г). В отличие от юговосточной части профиля, здесь отчетливо фиксируется проводящий внутрикоровый слой, причем положение его кровли на разрезе образует волнистую линию, варьируясь по глубине на смежных участках от 12 до 20 км. Это свидетельствует об определенной аналогии с полем УЭС юго-восточной (рифтовой) части профиля, т.е. обусловленности приподнятых участков кровли разломными зонами, а опущенных - сравнительно монолитными блоками. Отличие заключается в меньшей тектонической активности краевого участка платформы, в пределах которого разломные зоны обладают меньшей флюидопроводимостью и лишь сравнительно редко выражаются на геоэлектрическом разрезе широкими зонами низких значений УЭС, как это, например, характерно для баяндаевского участка профиля (70-75 $\mathrm{KM})$.

В целом магнитотеллурические зондирования по профилю Шертой - Крестовский впервые позволили детально изучить глубинную структуру области сочленения Сибирского кратона и Центрально-Азиатского пояса в центральной части Западного Прибайкалья. Ее сложность определяется тесным соседством структурно-вещественных комплексов, отражающих разные этапы активизации древней тектонической границы. В то же время кайнозойская структура территории достаточно отчетливо проявляется в виде системы зон повышенной нарушенности субстрата, проникающих до глубин 30 км. На северо-западном фланге профиля (в пределах платформы) такая зона сечет древние пологозалегающие толщи до глубин, на кото- 
рых располагается внутрикоровый проводящий слой. Юго-восточный фланг представлен серией нарушенных зон, которые наследуют неоднородности краевого шва, формируя проницаемую структуру западного плеча Байкальского рифта, вследствие чего здесь комплексы пород с высоким сопротивлением (порядка $10^{3}-10^{4}$ Ом·м) имеют сравнительно ограниченное распространение.

Совместная интерпретация геолого-геофизических данных проводилась путем сопоставления пространственного положения и размеров разнотипных аномалий на профиле Шертой - Крестовский. Установлено (рис. 6), что, несмотря на различие в происхождении изученных полей, их аномалии приурочены к одним и тем же участкам. При этом, судя по характеру количественных показателей и структурных особенностей таких участков, они представляют собой межблоковые зоны изучаемого региона. Субстрат зон вследствие нарушенности разрывами является высокопроницаемым для флюидов, миграция которых - одна из основных причин, приводящих к возникновению геофизических аномалий. Как правило, зонам соответствуют понижение в рельефе, максимум плотности линеаментов, пики объемной активности радона и количества распадов торона, максимум общей минерализации подземных вод и аномальные условия водообмена, минимум удельного электрического сопротивления, а также - в отдельных случаях - минимумы потенциала естественного электрического поля и модуля полного вектора магнитной индукции. Материалы по изученному сегменту позволяют рассмотреть с тектонофизических позиций иерархические взаимоотношения межблоковых зон с целью характеристики трансрегионального уровня, который представляют такие их разновидности, как разломные системы.

На рис. $6, A-B$, каждому рангу межблоковых структур соответствует определенный оттенок серого цвета, причем положение границ зон усреднено по нескольким признакам. Шесть из семи комплексных аномалий располагаются в юго-восточной части профиля Шертой - Крестовский, и только одна находится на северозападе и приурочена к осевой части Предбайкальского прогиба. Степень проявления шести зон в изученных полях характеризуется определенными качественными и количественными особенностями. Для второй $\left(1_{31}\right)$, четвертой $\left(1_{21}\right)$ и шестой $\left(1_{11}\right)$ зон, считая с юговостока (рис. 6, A), по сравнению с тремя другими в большинстве случаев свойственны более выраженные положительные аномалии $D, H, Q$ и $N$. C другой стороны, в рельефе эти зоны проявлены менее отчетливыми впадинами и представлены небольшими разломами разных морфогенетических типов. В отличие от них, первая $\left(1_{32}\right)$, третья $\left(1_{22}\right)$ и пятая $\left(1_{12}\right)$ зоны образованы крупными наклоненными на юго-восток сбросами (Прихребтовый, Приморский и Морской), перемещения по которым привели к формированию глубоких грабенов.

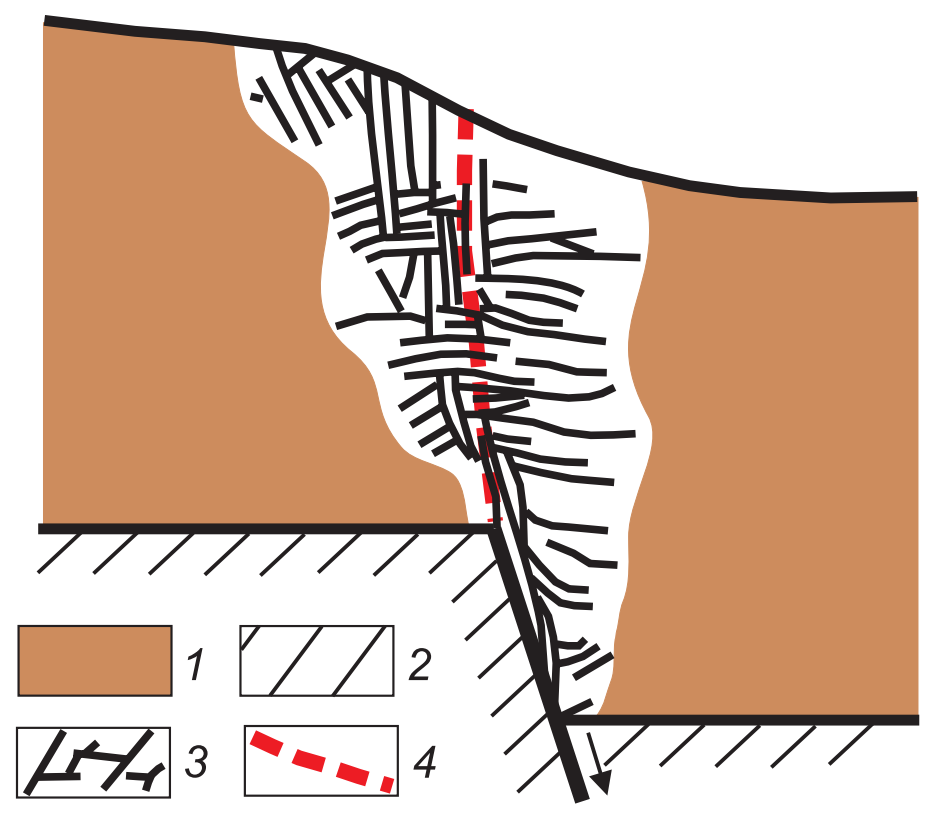

Рис. 7. Зона сбросового разлома, образовавшаяся в физическом эксперименте [Bokun, 1985].

1 - ненарушенные части модели из глинистой пасты; 2 - штампы экспериментальной установки (стрелкой показано направление смещения подвижного штампа); 3 - разрывы 2-го порядка, составляющие внутреннюю структуру сбросовой зоны; 4 - поверхность формирующегося сбросового сместителя (1-го порядка).

Fig. 7. The normal fault zone that occurred in the physical experiment [Bokun, 1985].

1 - undisturbed parts of the clay model; 2 - walls of the experimental module (the arrow shows the direction of displacement of the movable wall); 3 - fractures of the 2 nd order comprising the internal structure of the normal fault zone; 4 - the surface of the emerging normal fault plane (1st order).

Это свидетельствует о том, что зоны $1_{32}, 1_{22}$ и $1_{12}$ представлены глубинными, а три другие $\left(1_{31}, 1_{21}\right.$ и $\left.1_{11}\right)$ - близповерхностными дизъюнктивными структурами. Зоны образуют структурные пары, причем те из них, которые наиболее отчетливо выражены во всех изученных полях $\left(1_{22}-1_{21}\right.$ и $\left.1_{12}-1_{11}\right)$, расположены настолько близко друг к другу, что две аномалии на некоторых графиках объединяются в одну с двумя близко расположенными экстремумами. Описанные выше признаки свидетельствуют, что каждая из выделенных пар представляет крупную разломную зону сбросового типа, строение которой не раз воспроизводилось в тектонофизических экспериментах на упругопластичных моделях [Sherman et al., 1983; Bokun, 1985; Grigoriev et al., 1987] (рис. 7). Такие зоны расширяются снизу вверх и на поверхности по особенностям внутреннего строения делятся на две подзоны. Главным структурным элементом первой из них (фронтальной) является крупный сброс магистрального типа, тогда как вторая (тыловая) выражена системой сравнительно небольших продольных сбросов и косоориентированных к 
ним право- и левосторонних сдвигов. На ранних этапах разломообразования в приповерхностной части деформируемого объема подзоны отделены друг от друга практически ненарушенным участком, который обычно исчезает по мере развития процесса. Глубинное строение рассматриваемой половины профиля Шертой-Крестовский также не противоречит представленной модели (см. рис. 6, Г). Зоны трех крупных сбросов на геоэлектрическом разрезе выделяются областями с очень низким (4-30 Ом·м) сопротивлением вследствие обводнения интенсивно нарушенных участков земной коры. Две из трех пар межблоковых зон, объединяющихся по данным малоглубинных методов $\left(1_{32}-1_{31}\right.$ и $\left.1_{12}-1_{11}\right)$, выделяются в виде широких полос минимальных удельных сопротивлений. В отличие от них Приморская зона (участки $1_{22}-1_{21}$ ) маркируется у поверхности лишь небольшим минимумом под Приморским сбросом, однако на глубинах 12-30 км ей может соответствовать полосовидный в разрезе участок низких сопротивлений, выполаживающийся в юго-восточном направлении.

Таким образом, в юго-восточной части профиля Шертой - Крестовский выделяются три межблоковые структуры регионального уровня, которые в тектонофизическом отношении представляют классические примеры крупных разломных зон. Ключевую роль в их строении играют зоны главных рифтообразующих сбросов - Прихребтового, Морского и Приморского, закономерности проявления последнего из которых в разнотипных геолого-геофизических полях были детально рассмотрены в предыдущем разделе статьи. Эти круто наклоненные разрывные структуры приурочены к полосам распространения древних тектонитов и, уходя на глубину, пересекают палеозойские надвиги ( $\approx 30$ км профиля), положение которых оказалось менее благоприятным для активизации при рифтообразовании в кайнозое. В тылу каждого из трех глубинных дизъюнктивов имеют место близповерхностные, но соизмеримые по мощности зоны растяжения. Деструкция земной коры в их пределах происходит менее интенсивно за счет активизации древней сети сопряженных меридиональных и широтных сдвигов, а также сравнительно небольших северо-восточных сбросов. Возможно, на глубине тыловые зоны не сочленяются с главными дизъюнктивами, но в любом случае они отражают внутреннее строение трех региональных межблоковых структур разломного типа - Морской, Приморской и Прихребтовой.

На следующем трансрегиональном уровне иерархии логично объединить три рассмотренные разломные зоны в единую межблоковую структуру, охватывающую всю юго-восточную (0-45 км) половину профиля Шертой - Крестовский (см. рис. 6, A). Основанием для такого объединения является то, что участки, занимаемые здесь межблоковыми зонами, по размерам превалируют над участками, которым соответствуют менее нарушенные блоки, представленные Приоль- хонской краевой ступенью и Приморским глыбовым поднятием (см. рис. 6, Б). Согласно данным геологогеофизических методов, эта закономерность в наибольшей степени проявлена в приповерхностной части земной коры (см. рис. 6, B), но может быть свойственна и более глубоким горизонтам коры (см. рис. 6, Г). Кроме данного критерия, основанного на результатах анализа комплекса геофизических съемок, объективность отнесения юго-восточной части профиля к крупной (трансрегиональной) межблоковой структуре подтверждается единством ее внутреннего строения. В пределах зоны отчетливо проявлена закономерность локализации деформаций, выраженная в виде тенденции уменьшения расстояния между одноранговыми зонами регионального уровня с северо-запада на юговосток, что свидетельствует о характерном возрастании интенсивности нарушенности субстрата от периферии к главной поверхности сбросовых смещений (Морской разлом). При этом три зоны регионального уровня имеют близкую пространственную ориентировку, характеризуются сбросовым типом перемещений и, как следствие, - общими чертами внутреннего строения. Кроме того, Приморский и Морской разломы, сочленяясь у п. Бугульдейка, образуют связную разрывную сеть. Перечисленные признаки позволяют, согласно [Gibbs, 1990; Park, 1997], отнести всю юговосточную половину профиля к Обручевской разломной системе растяжения (extensional fault system). По сравнению с представлениями предшественников [Mats, 1993], объединивших ранее Морской и Приморский сбросы в единую систему, ее поперечный размер увеличился почти в два раза.

Обручевская межблоковая зона - разломная система растяжения - занимает соответствующее место в иерархии зонно-блокового строения литосферы Западного Прибайкалья (см. рис. 6, A). С одной стороны, она состоит из трех региональных разломных зон (Прихребтовая, Приморская и Морская), а с другой - образует северо-западное плечо Байкальского рифта как представителя межблоковых структур глобального уровня. В рамках трансрегионального уровня Обручевская разломная система контактирует с крупным слабонарушенным блоком, другой границей которого является Предбайкальская межблоковая зона, причем два последних структурных элемента относятся к платформе.

\subsection{2. Сегмент Западный берег - Восточный берег}

Профиль пересекает центральную часть акватории оз. Байкал и, как следствие, отличается от других сегментов трансекта малой протяженностью и ограниченным количеством методов исследования, реализованных в его пределах авторами статьи. Вместе с тем реализованные виды работ (изучение зоны Морского разлома на подводном склоне с борта глубоководного обитаемого аппарата (ГОА) «Мир-2», МТЗ со льда 
озера со средним шагом между пунктами измерений $\approx 3$ км) отличаются новизной и оригинальностью, а их результаты в совокупности с данными предшественников позволяют получить важную информацию о проявлении межблоковых зон в пределах этой труднодоступной для исследования территории.

Известные батиметрические данные и материалы многоканального сейсмопрофилирования [Hutchinson et al., 1992; Scholz et al., 1993; Levi et al., 1995; Kaz'min et al., 1995; Moore et al., 1997; ten Brink, Taylor, 2002] свидетельствуют о достаточно простом в целом строении Байкальской впадины, соответствующем в окрестностях изучаемого профиля крупному грабену. При некоторой асимметрии впадина в целом отличается наличием крутых бортов, которые представлены зонами региональных разломов. Интенсивные позднекайнозойские перемещения по этим разломам, происходящие в условиях растяжения земной коры, частично скомпенсированы процессом формирования байкальских осадков, мощность которых в районе трансекта составляет примерно 7 км [Ten Brink, Taylor, 2002]. Поверхность осадков по сравнению с бортовыми зонами имеет слаборасчлененный рельеф, обусловленный небольшими (у поверхности) подвижками по разломам, схемы которых составлялись разными исследователями на основе главным образом интерпретации данных многоканального сейсмопрофилирования (например [Levi et al., 1997b]). Преобладание широтных, меридиональных, северо-западных и северо-восточных нарушений сбросового и сдвигового типов свидетельствует о подобии разрывных сетей, формирующихся в пределах береговой и подводной территорий под действием растяжения земной коры в направлении С3ЮB [Seminsky, 2003].

Несмотря на существенно менее контрастное в сравнении с бортовыми частями проявление разрывов в рельефе дна Байкальской впадины, признаком интенсивных современных смещений по разломам в окрестностях трансекта является высокая сейсмичность с очагами на глубинах 10-22 км [Suvorov, Tubanov, 2008; Tat'kov, 2009]. При этом эпицентры землетрясений с $\mathrm{K} \geq 7$, произошедших в районе исследований в 20002005 гг., сосредоточены в пределах трех полос северовосточного простирания, характеризующихся сдвигосбросовыми и раздвиговыми деформациями. Северозападная полоса (рис. 8, A) может быть связана с перемещениями на сейсмогенных глубинах блоков по сегментам Морского разлома - главного сместителя Обручевской системы, поверхность которого наклонена на юго-восток. Вторая из полос также находится в границах акватории озера, пространственно тяготея к осевой части Байкальского рифта (рис. 8, A). Третья полоса повышенной концентрации эпицентров землетрясений располагается главным образом в береговой части и на юго-западе ассоциируется с Дельтовой разломной зоной, которая составляющим элементом входит в Черско-Баргузинскую разломную систему на восточ- ном плече рифта. Несмотря на то, что по ширине и количеству землетрясений с $\mathrm{K} \geq 7$ центральная полоса доминирует над бортовыми, ранг обусловливающей ее появление межблоковой зоны не может быть выше регионального. В этом статусе она нарушает опущенный блок Байкальской впадины, который вместе с Обручевской и Черско-Баргузинской системами представляет трансрегиональный уровень в зонно-блоковой структуре региона.

Таким образом, наиболее значимой структурой, входящей в состав межблоковой зоны трансрегионального уровня и пересеченной профилем Западный берег - Восточный берег, является Морской сброс, так как в его зоне происходит большая часть вертикальных смещений, реализующихся в пределах Обручевской разломной системы. Протягиваясь вдоль побережья Приольхонья и о. Ольхон, он в настоящее время скрыт под водами оз. Байкал и вследствие этого может быть изучен только посредством привлечения геофизических и глубоководных методов исследования. Авторы работы [San'kov et al., 2009] связывают с этим разломом максимум современных горизонтальных деформаций растяжения вкрест Байкальской впадины, рассчитанных по данным GPS-геодезии.

Основным источником представленных ниже сведений о близповерхностном строении зоны Морского сброса являются структурно-геологические материалы нескольких погружений в районах Приольхонья (падь Бегул - мыс Бирхин) и о. Ольхон (мыс Ижимей) в 1990-1991 гг. ГОА «Пайсис», которые были обработаны и опубликованы их участниками А.А. Бухаровым и В.А. Фиалковым [Bukharov, Fialkov, 1996]. Они иллюстрируются на рис. 9, составленном одним из авторов статьи по результатам погружения на ГОА «МИР-2», проведенного в рамках проекта «МИРы на Байкале» (2008-2010 гг.) в районе пр. Ольхонские Ворота с целью исследования внутреннего строения зоны Морского сброса (рис. 9, В).

Подводный материковый склон вследствие присутствия активной сбросовой зоны характеризуется значительной крутизной: между пологой прибрежной отмелью и глубоководной равниной, находящимися примерно в 1 км друг от друга, глубина изменяется практически на километр. Как следствие, склон подвержен интенсивному эрозионно-тектоническому разрушению, формирующему ступенчато-глыбовый рельеф. Эрозия склона проявляется в виде подводных обвалов, осыпей и оползней, которые распространены в большей степени, чем это характерно для аналогичных ситуаций на береговой территории Западного Прибайкалья. Несмотря на наличие многочисленных разноранговых и разноориентированных уступов, трогов, рвов, поднятых и опущенных блоков, в качестве доминирующих выделяются северо-западные гряды и троги, а также уступы северо-восточного простирания, которые у подножия часто осложнены достаточно глубокими рвами (рис. 9, B). 


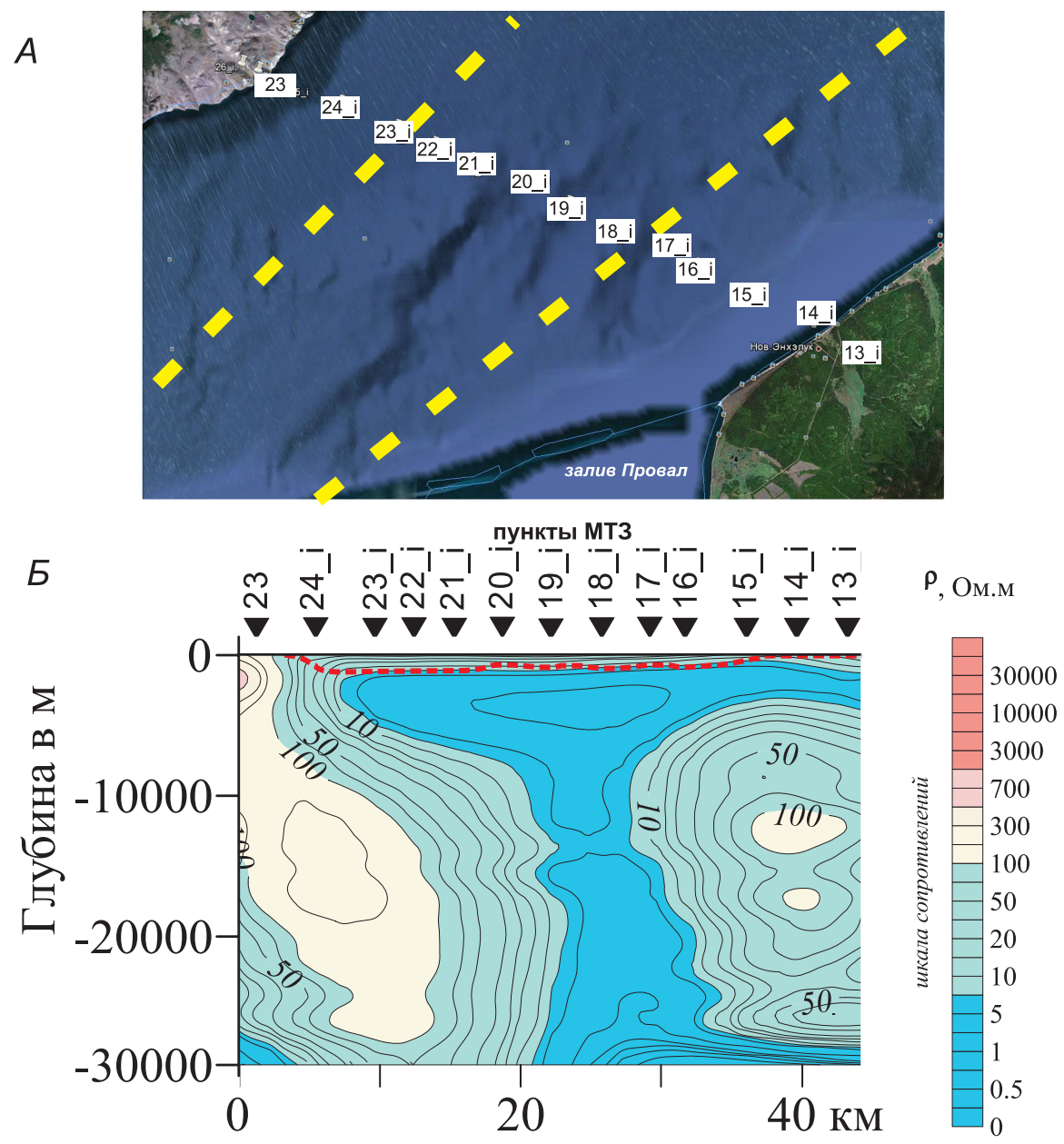

Рис. 8. Положение пунктов измерения на льду оз. Байкал (А) и геоэлектрический разрез (Б), построенный по данным магнитотеллурических зондирований для сегмента трансекта Западный берег - Восточный берег.

Желтый пунктир - положение осей двух полос высокой плотности эпицентров землетрясений, согласно [Suvorov, Tubanov, 2008].

Fig. 8. Locations of measurements sites on ice of Lake Baikal (A), and the geoelectric profile $(Б)$ constructed according to magnetotelluric sounding data on the Western shore - Eastern shore transect's segment.

The yellow dashed line shows positions of axes of two bands of the high density of earthquakes epicentres according to [Suvorov, Tubanov, 2008].

Эти геоморфологические элементы подводного склона формируются в результате активных перемещений по системе разрывов, определяющих внутреннюю структуру зоны Морского разлома. Среди них преобладают разноранговые сбросы, которые, обнажаясь в бортах рвов и трогов (рис. 9, Г), образуют ступенчатый выполаживающийся с глубиной поперечный профиль (рис. 9, Б). Выделяются два наиболее крупных продольных сместителя, зафиксированных по структурным и геоморфологическим признакам на всех участках погружения на глубинах 350-450 и 650700 м. В пределах отмеченных интервалов отмечаются выходы подземных вод, субвертикальные штрихи скольжения, а также высокая степень выветривания древних пород, которые при попытке отбора образца манипулятором аппарата «МИР-2» обычно рассыпаются до дресвы. Это свидетельствует, с одной сторо- ны, об открытости разломов, а с другой - о наследовании позднекайнозойскими сбросами зон более древних нарушений, существовавших на рассматриваемой территории в период интенсивного формирования латерит-каолиновой коры выветривания.

Еще одной крупной продольной структурой в зоне Морского сброса является флексурообразный перегиб на переходе от склона к глубоководной равнине, который, вероятно, представляет собой главную плоскость вертикальных перемещений, осуществляющихся в настоящее время. Сместитель недоступен для непосредственных структурных наблюдений, так как перекрыт слоем современных осадков, однако в ряде мест были зафиксированы специфические сейсмогенные структуры (сочетание рвов и валов), свидетельствующие о недавних импульсных подвижках по его поверхности. Что касается проявления в толще рых- 


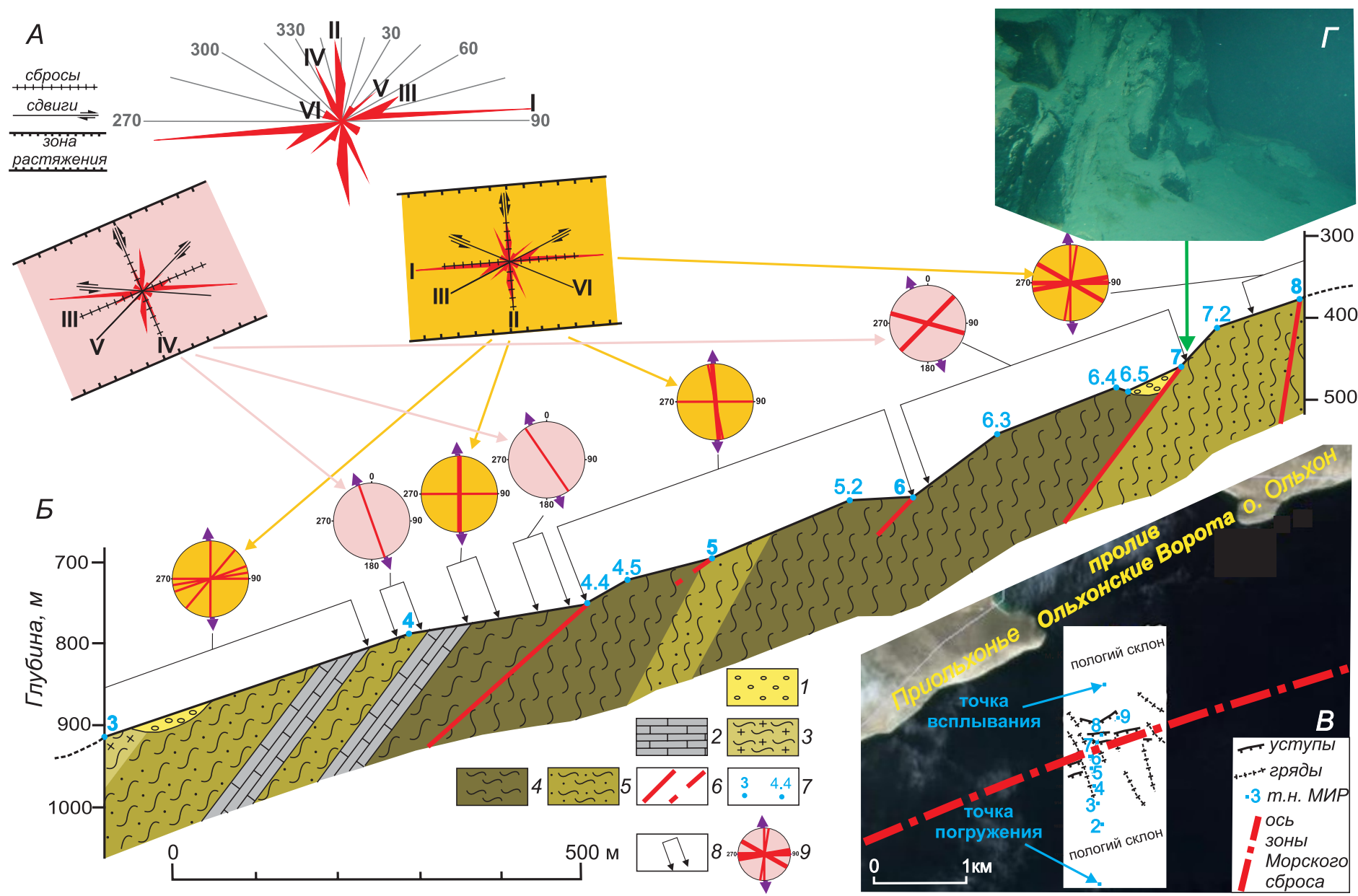

Рис. 9. Результаты подводных структурно-геологических исследований по профилю, пересекающему сместитель Морского сброса в районе пролива Ольхонские Ворота.

$A$ - роза-диаграмма зафиксированных на подводном склоне разломов и трещин, пять основных систем которых образуют парагенезисы двух зон растяжения северо-восточной и широтной ориентировок (полный набор разрывных систем зоны растяжения приведен согласно [Seminsky, 2003; Seminsky, Cheremnykh, 2011]); Б - схематичный геолого-структурный разрез по маршруту ГОА «Мир-2» с отраженными на круговых диаграммах результатами парагенетического анализа разрывов: 1 - глинистые и илистые осадки с глыбами скальных пород; 2 - мраморы; 3 - мигматиты; 4 - гранитогнейсы; 5 - выветрелые гранитогнейсы; 6 - зафиксированные и предполагаемые разломы; 7 номера точек наблюдения; 8 - границы участка измерений разрывов, представленных на одной диаграмме; 9 - круговые диаграммы простираний разломов (жирные линии) и крупных трещин (тонкие линии), формирующихся, согласно данным парагенетического анализа, при растяжении (фиолетовые стрелки); $B$ - схема расположения уступов, гряд и точек наблюдения на подводном склоне в пределах участка исследований; $\Gamma$ - фотография одного из продольных сбросов зоны Морского разлома, сформировавших уступ на подводном склоне.

Fig. 9. Results of underwater structural geophysical studies along the profile across the Morskoy fault plane near the Olkhon Gate Strait.

$A$ - the rose diagram of faults and fractures recorded at the underwater slope; these five main systems comprise two extension zones oriented in the north-eastern and latitudinal directions (a complete set of the fault systems of this extension zone is described in [Seminsky, 2003; Seminsky, Cheremnykh, 2011]); 5 - the schematic structural geological cross-section along the route of Mir-2 submarines, and circle diagrams showing results of the paragenetic analysis of faults. 1 - clayey and silty sediments with rocky lumps; 2 - marble; 3 - migmatite; 4 - granite-gneiss; 5 weathered granite-gneiss; 6 - recorded and assumed faults; 7 - numbers of observation sites; 8 - boundaries of sites wherein faults were measured and then shown in one diagram; 9 - circle diagrams of strikes of faults (thick lines) and large joints (thin lines) which occur due to extension (purple arrows), according to the paragenetic analysis of the data; $B$ - the scheme showing positions of benches, ledges, and observation sites at the underwater slope within the area under study; $\Gamma$ - the photo shows a longitudinal normal fault in the Morskoy fault zone; a set of such faults comprises a bench at the underground slope. 
лых отложений отдельных разломов, составляющих крупные зоны подобного типа, то они могут быть аналогичны изученным в керне скважины BDP-96, которая была пройдена на склоне подводного Академического хребта. Участок глубоководного бурения располагался на продолжении в акваторию озера Приморской сбросовой зоны, один из сместителей которой был пересечен стволом скважины. Согласно результатам наших исследований [Seminsky et al., 2001], в керне зафиксированы разноранговые разрывы, слабо выраженные по сравнению с проявлениями аналогичных нарушений в более литифицированной породе. В пластичном осадке даже активные трещины имеют латентный вид, а пассивные и вовсе ассимилируют в течение непродолжительного времени (рис. 10, в-л). Наиболее нарушенный участок разреза (180-500 м) представляет наклонную разрывную зону (главный максимум на рис. $10, a$, построенном по большому интервалу вычисления плотности разрывов), которая состоит из серии аналогичных зон 2-го порядка (пронумерованные максимумы на рис. 10 , б, построенном с меньшим почти на порядок интервалом вычисления плотности разрывов). Внутренняя структура последних (рис. 10, $u$ ) на периферии представлена в основном трещинами отрыва, а в приосевой части - трещинами скола, которые ориентированы в соответствии с известными для зон скалывания закономерностями, свидетельствующими в данном случае о сбросовых перемещениях (рис. 10, м). Судя по слабой дислоцированности осадка, воздействие тектонических сил в данном случае было не настолько интенсивным и продолжительным, чтобы привести к возникновению единого, сравнительно крупного разломного сместителя. Следовательно, строение этого разлома в осадочной толще соответствует ранней дизъюнктивной стадии.

Важной особенностью извилистой в плане зоны Морского сброса является осложнение ее внутреннего строения в местах резкого изменения простирания, как это, например, было установлено при изучении подводного склона в районе пр. Ольхонские Ворота. Здесь разлом меняет ориентировку от северо-восточной до субширотной, что проявляется в виде наложения сбросовых парагенезисов, соответствующих каждому из этих направлений зоны растяжения (см. рис. 9, А-B). Роза-диаграмма, построенная по результатам замеров простираний разломов и крупных трещин вдоль маршрута ГОА «МИР-2», позволяет выделить шесть значимых направлений разрывов, которые можно, основываясь на эталонном парагенезисе структур 2-го порядка в зонах растяжения [Seminsky, 2003; Seminsky, Cheremnykh, 2011], разделить на две группы (см. рис. 9, A). Доминирование совокупности разрывов субширотной зоны растяжения (системы I-II-III-VI) над северо-восточной (системы III-IV-V) не является однозначным свидетельством существования здесь регионально значимой обстановки меридионального растяжения. Согласное с частью сбросовых разломов суб- широтное залегание пород в районе исследования, скорее всего, свидетельствует о пассивном изменении первичной северо-восточной ориентации структур, которое обусловлено вращением по часовой стрелке о. Ольхон и северо-восточной части Приольхонья как единого блока в результате неравномерного растяжения коры в ходе образования рифта [Seminsky, 1994].

Дополнительной структурной особенностью рассматриваемого участка подводных исследований, установленной ранее для сухопутной территории [Logachev, 1994; Seminsky, 1994], является широкое развитие поперечных разрывов (см. рис. 9, А-Б), представляющих борта субмеридиональных и северо-западных гряд и трогов. Это, наряду с нескомпенсированностью литогенетическими процессами и локализованностью деформаций в узкой полосе материкового склона, свидетельствует о высокой интенсивности растяжения в зоне Морского сброса, превышающей масштабы аналогичного процесса, характерного для других рифтообразующих дизъюнктивов Центрального Прибайкалья. Судя по материалам погружений на подводном аппарате «Пайсис» [Bukharov, Fialkov, 1996], отмеченное выше относится и к разломам восточного берега. Известная асимметрия поперечного профиля Байкальского рифта в данном случае выражается в том, что на его восточном плече растяжение реализуется по нескольким дизъюнктивам Дельтовой разломной зоны, которая представляет северо-западную часть ЧерскоБаргузинской разломной системы (см. рис. 2, Б).

Таким образом, на сегменте трансекта Западный берег - Восточный берег выявлены определенные особенности структурного проявления крупных разрывных зон, представляющих разломные системы западного и восточного плечей рифта. Однако по большому счету они определяются не специфическими условиями локализации в Байкальской впадине, а высокой интенсивностью процесса деструкции. Это отражается в больших амплитудах вертикальных перемещений, сконцентрированных в сравнительно узкой зоне Морского сброса, представляющего Обручевскую разломную систему, а также сейсмичности, наиболее интенсивные проявления которой тяготеют к северо-западной части Черско-Баргузинской системы, а также, собственно, к оси рифта.

Отмеченные особенности близповерхностного строения в полной мере отражаются в глубинной структуре земной коры (см. рис. 8), изученной геофизическими методами непосредственно под оз. Байкал вдоль профиля Западный берег (мыс Крестовский) Восточный берег (пос. Энхалук). Следует отметить, что геоэлектрические исследования по близким профилям, проложенным в том числе и по льду озера, осуществлялись двумя группами специалистов. Первая из них [Glinsky et al., 1991; Morozova et al., 1998] интерпретировала данные глубинного зондирования становлением электромагнитного поля и метода зондирования становлением поля в ближней зоне (ЗСБ). В 


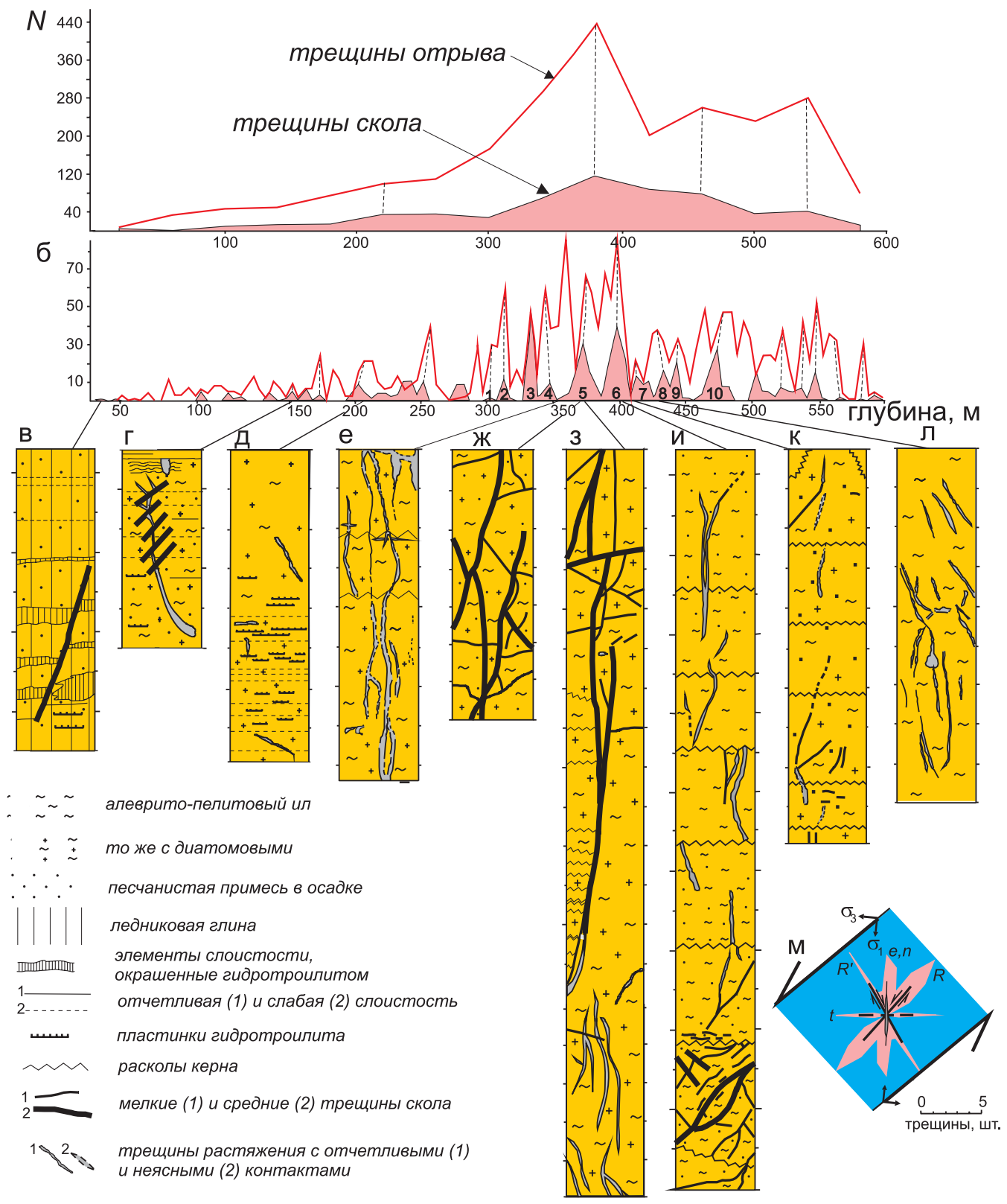

Рис. 10. Результаты исследования разнотипных разрывов в донных осадках оз. Байкал района Академического хребта, полученные по данным документирования керна глубоководной скважины BDP-98.

$a-\sigma$ - графики изменения плотности $(N)$ трещин растяжения и скола (залито розовым цветом) с глубиной $(Z)$, построенные для разных интервалов осреднения: $a-40$ м; $\sigma-5$ м (пунктир - совпадающие максимумы плотности трещин скола и отрыва); в-л - примеры характерных структурных ситуаций в керне на основе первичной документации, выполненной Е.Б. Карабановым, А.Н. Гвоздковым, К. Накамурой и А.А. Прокопенко (расстояние между рисками на вертикальной шкале - 5 см); м - интерпретация (разрез) структуры в наиболее нарушенном трещинами участке керна “и”: системы трещин в керне, выявленные по розе-диаграмме (розовый цвет), соответствуют разрывам 2-го порядка ( $R$-, $R^{\prime}-, n-, t-, e$-типов) в зоне скалывания (синий цвет) сбросового типа (стрелки - направление движения висячего и лежачего крыльев), образовавшейся в поле напряжений с горизонтальным положением оси растяжения и вертикальным - оси сжатия.

Fig. 10. Results of the studies of different types of fractures in the bottom sediments of Lake Baikal in the area of the Akademichesky ridge, according to data from core sampling of deep-water well BDP-98.

$a-\sigma-$ curves showing changes of density (N) of extension joints and shear fractures (filled in pink) with depth (Z). The curves are constructed for different averaging intervals: $a-40 \mathrm{~m} ; \sigma-5 \mathrm{~m}$ (the dotted line shows similar maximum values of density of shear fractures and separation joints); B- $\Omega$ - examples of typical structural patterns in the core samples on the basis of data from original documents issued by E.B. Karabanov, A.N. Gvozdkov, K. Nakamura and A.A. Prokopenko ( $5 \mathrm{~cm}$ distance between reference points at the vertical scale); $\boldsymbol{M}-$ interpretation (cross-section) of the structural pattern of the core's segment ("и") which is most disturbed by fractures: the systems of fractures in the core which are identified from the rose diagram (pink) correspond to joints of the $2 n d$ order ( $R$-, $R^{\prime}-, n-, t-, e$-types) in the shear zone (blue) of normal type (arrows show movement directions of the hanging wall and the foot wall); this zone occurred in the stress field which extension axis is horizontal and the compression axis is vertical. 
районе восточного окончания профиля на глубинах 10-12 км ими были выделены фрагменты проводящего слоя с удельным сопротивлением в первые десятки Ом·м, а также серия субвертикальных разломов, с которыми совпадают зоны шириной 2-4 км с высокой проводимостью геологического субстрата (сопротивление - 10-55 Ом·м). По профилю до глубин 10 км был реконструирован неоднородный в геоэлектрическом отношении разрез с сопротивлением 200-300 Ом·м в верхней части и УЭС $\approx 2000$ Ом·м - в нижней. Вторая группа специалистов [Moroz Yu.F., Moroz T.A., 2012] использовала данные МТЗ с 14 пунктами, 5 из которых принадлежали собственно акватории озера, и реконструировала горизонтально-слоистый в целом геоэлектрический разрез до глубин 400 км.

Проведенные нами магнитотеллурические зондирования в плане детальности профилирования (12 пунктов в акватории) занимают по отношению к предшествовавшим работам промежуточное положение. Они не претендуют на детализацию геоэлектрического разреза под оз. Байкал, свойственную построениям исследователей из первой группы. Напротив, генерализация измеренных величин позволила выявить главные особенности поля УЭС для рассматриваемого участка земной коры, причем они в существенной мере дополняют закономерности, выявленные специалистами из второй группы. Так, геоэлектрический разрез впадины, представленный на рис. 8, Б, свидетельствует в целом о крайне низких сопротивлениях изучаемого участка земной коры, которые в направлении от прибрежных районов к оси впадины уменьшаются от 100-150 до 0.5 Ом·м. Исключение составляет верхний, ограниченный на рисунке красным пунктиром, тонкий слой с сопротивлением 100-300 Ом·м, который можно отождествить с пресными водами оз. Байкал. Особое значение имеет осевая (в разрезе) часть низкоомной аномалии, которая в первом приближении состоит из двух основных сегментов. Один из них располагается сразу под водой и имеет форму горизонтально вытянутой линзы мощностью примерно 7 км. Второй сегмент представляет низкоомную зону шириной 7-10 км, которая наклонена на юго-восток под углом $\approx 75^{\circ}$ и присоединяется к горизонтальной линзе у ее основания. Параметры низкоомной аномалии, высокая нарушенность субстрата и условия растяжения земной коры позволяют предположить, что происхождение низких сопротивлений связано, во-первых, с телом байкальских осадков (субгоризонтальный сегмент) и, во-вторых, с флюидизированной зоной (субвертикальный сегмент), причем, согласно известным предположениям [Pinneker et al., 1998; Berdichevsky et al., 1999; Golubev, 2007], в этой зоне может происходить миграция как поверхностных, так и глубинных потоков.

Объединяя структурные и электроразведочные данные, полученные по профилю Западный берег - Восточный берег, необходимо отметить, что, несмотря на специфические условия деструкции, особенности зон- но-блокового строения земной коры в районе котловины оз. Байкал проявляются достаточно отчетливо. Наиболее интенсивно процесс протекает в межблоковых структурах, которые являются ближними к оси рифта региональными зонами - Морской и Дельтовой, принадлежащими, соответственно, к Обручевской и Черско-Баргузинской разломным системам. Морская зона выделяется локализованностью сбросовых перемещений, которая проявляется в контрастности подводного рельефа, а также формировании густой сети разноранговых разрывов в скальных породах и слабосцементированных осадках. В Дельтовой межблоковой зоне эти характеристики существенно ниже вследствие рассредоточенности процесса деструкции на восточном плече рифта, развитие которого на современном этапе отличается сравнительно высокой сейсмической активностью. Главным элементом трансрегионального уровня, занимающим большую часть изученного профиля, является блок Байкальской впадины, опущенный в результате активных перемещений по Обручевской и Черско-Баргузинской разломным системам. Его центральную часть нарушает межблоковая зона, которая по размерам относится к региональному рангу, а по некоторым показателям современной активности соизмерима со смежными зонами плечей рифта - Морской и Дельтовой или превосходит их. При небольшом наклоне на юго-восток и ширине 7-10 км зона контролирует большинство землетрясений в регионе с $K \geq 7$ и, судя по низким величинам удельных электрических сопротивлений, характеризуется высокой флюидонасыщенностью. Учитывая эти особенности в совокупности с раздвиговым характером деформации [Suvorov, Tubanov, 2008; Tat'kov, 2009] и сравнительно слабой выраженностью зоны на поверхности осадков дна оз. Байкал, следует предположить, что при одновременной реализации в ее пределах отрыва и скалывания первый механизм (особенно при наличии давления флюидов) играет главную роль в структурообразовании.

\subsection{3. Сегмент Кудара - Тарбагатай}

В основу выделения межблоковых зон трансрегионального уровня на данном участке трансекта положены результаты полного комплекса исследований, включая геолого-структурные и морфотектонические наблюдения, электроразведку методами ЕП, СЭП и MT3, магниторазведку, радон-тороновую съемку и гидрогеохимическое опробование водопроявлений. На рис. 3 представлены вариации параметров, измеренных в поле, а на рис. 11 - кривые, построенные по выборке данных с шагом, соответствующим выбранному масштабу исследования разломных систем.

Как видно из геологического разреза (рис. 11, Б) профиль Кудара - Тарбагатай проходит в пределах Центрально-Азиатского пояса и охватывает область распространения интрузивных образований протеро- 
зоя и палеозоя, а также (в северо-западной части) метаморфических пород докембрия. В мезокайнозойское время на этом геологическом субстрате образовались впадины за счет вертикальных перемещений по разломам, главными из которых являются Дельтовый, Бортовой (Хамар-Дабанский), Джида-Удинский и др. В итоге сформировался рельеф с чередованием в направлении СЗ-ЮВ отрицательных и положительных форм: Усть-Селенгинская впадина, Фофановская кристаллическая перемычка, Селенгино-Итанцинская впадина, поднятие хребта Хамар-Дабан, Иволгино-Удинская впадина и поднятие Ганзуринского хребта. Впадинам, а особенно их прибортовым участкам, соответствуют максимумы плотности линеаментов рельефа (рис. $11, B$ ), отражающие контрастные перемещения в пределах крупных разломных зон.

Тектонофизические реконструкции, осуществленные в итоге полевых наблюдений за разломами и трещинами, подтвердили известные для региона особенности формирования его структуры на последнем этапе тектогенеза, приведшем к формированию Байкальского рифта. В обстановке доминирующего растяжения земной коры в направлении С3-ЮВ произошли перемещения по крупным сбросам, поверхности которых наклонены главным образом по направлению к оси рифта. Исключение составляет зона регионального Джида-Удинского разлома, характеризующегося падением в противоположную сторону. Руководствуясь важностью исследования этого дизьюнктива в плане принятия решения о принадлежности рассматриваемого участка земной коры к Байкальскому рифту, результаты тектонофизического анализа для соответствующего отрезка трансекта приведем ниже несколько подробнее, чем это было сделано для других разломных зон аналогичного ранга. В зоне Джида-Удинского разлома было изучено 13 выходов разновозрастных горных пород, в пределах которых основу геологоструктурных наблюдений составлял массовый замер элементов залегания трещин и мелких разломов. Эти данные были обработаны при помощи авторской разновидности структурно-парагенетического анализа [Seminsky, 2003; Seminsky, Burzunova, 2007; Seminsky, Cheremnykh, 2011], которая, кроме реконструкции в отдельных точках локальных полей напряжений, позволяет провести их поранговый анализ и определить разновидности региональных динамических обстановок, внесших наибольший вклад в формирование внутренней структуры разломной зоны. Не останавливаясь на деталях анализа, подробно описанных в цитированных публикациях, необходимо отметить, что в итоге его проведения было выявлено три главных типа динамических обстановок формирования Джида-Витимской разломной зоны (рис. 12). Это сжатие (12 \%), левый сдвиг (8\%), а также растяжение, которое делится на три разновидности, связанные с формированием северо-восточных (33 \%), восток-северо-восточных (33 \%) и субширотных (14\%) сегментов Джида-
Удинского разлома. Подобные обстановки, согласно данным предшествовавших исследований полей напряжений [Logachev, 1994; Seminsky, 1994, 2003, 2009; Petit et al., 1996; Levi et al., 1997a; Delvaux et al., 1997], доминируют в центральной части Байкальского рифта и связываются с раннепалеозойским (сжатие), раннекайнозойским (сдвиг) и позднекайнозойским (растяжение) этапами развития земной коры Прибайкалья. Кроме того, это соответствует реконструкциям позднекайнозойского полеонапряженного состояния, выполненными впервые для Хамбинского, Темникского, Тугнуй-Кондинского и Боргой-Большеречинского разломов в работе [San'kov et al., 2003]. Таким образом, тектонофизические данные не противоречат решению об отнесении изученного участка земной коры к Байкальскому рифту.

Данные опробования источников подземных вод подтверждают результаты гидрогеологических исследований, полученные для сегмента Шертой - Крестовский и, в первую очередь, - о связи анионного состава с рельефом. Так, областями питания поверхностных вод являются поднятые участки рельефа, а разгрузки располагающиеся между ними линейно вытянутые депрессии. Однако на рассматриваемом участке в пределах разломных зон состав вод более интенсивно, чем это было характерно для западного плеча Байкальского рифта, меняется за счет глубинной составляющей, переходя в класс минерализованных, а зачастую и термальных (источники в районе п. Энхалук, п. Горячинск и др.). Положение терм, в первом приближении коррелирующее с распределением эпицентров землетрясений, определяется степенью современной тектонической активности, которая в этом отношении выше на рассматриваемом сегменте трансекта по сравнению с северо-западным.

Геофизические поля, согласно графикам изменения их параметров (см. рис. 3, 11, B), интенсивно варьируются вдоль профиля. При этом на фоне малоамплитудных колебаний значений каждого из показателей прослеживаются отчетливые тенденции изменений изученных полей, которые отражают неоднородное строение земной коры в трансрегиональном масштабе. Характерно то, что эти тенденции подобны, с одной стороны, для полей электромагнитной (см. рис. $11, \Gamma$, рис. $11, B$ : параметры $\rho_{\kappa}, U$ и $\left.T\right)$, а с другой - эманационной (рис. $11, B$ : параметры $Q$ и $N$ ) природы. В полях первой группы отчетливая неоднородность вылеляется в центральной части изученного профиля (45-65 км), которой в рельефе земной поверхности соответствует хр. Хамар-Дабан. В магнитном поле и поле удельного электрического сопротивления (в т.ч. - до глубины 30 км) она выражена максимумами, а в поле потенциала ЕП - минимумом, причем два последних параметра на данном участке характеризуются экстремальными значениями.

Для второй группы полей часть профиля, располагающаяся северо-западнее хр. Хамар-Дабан, не являет- 

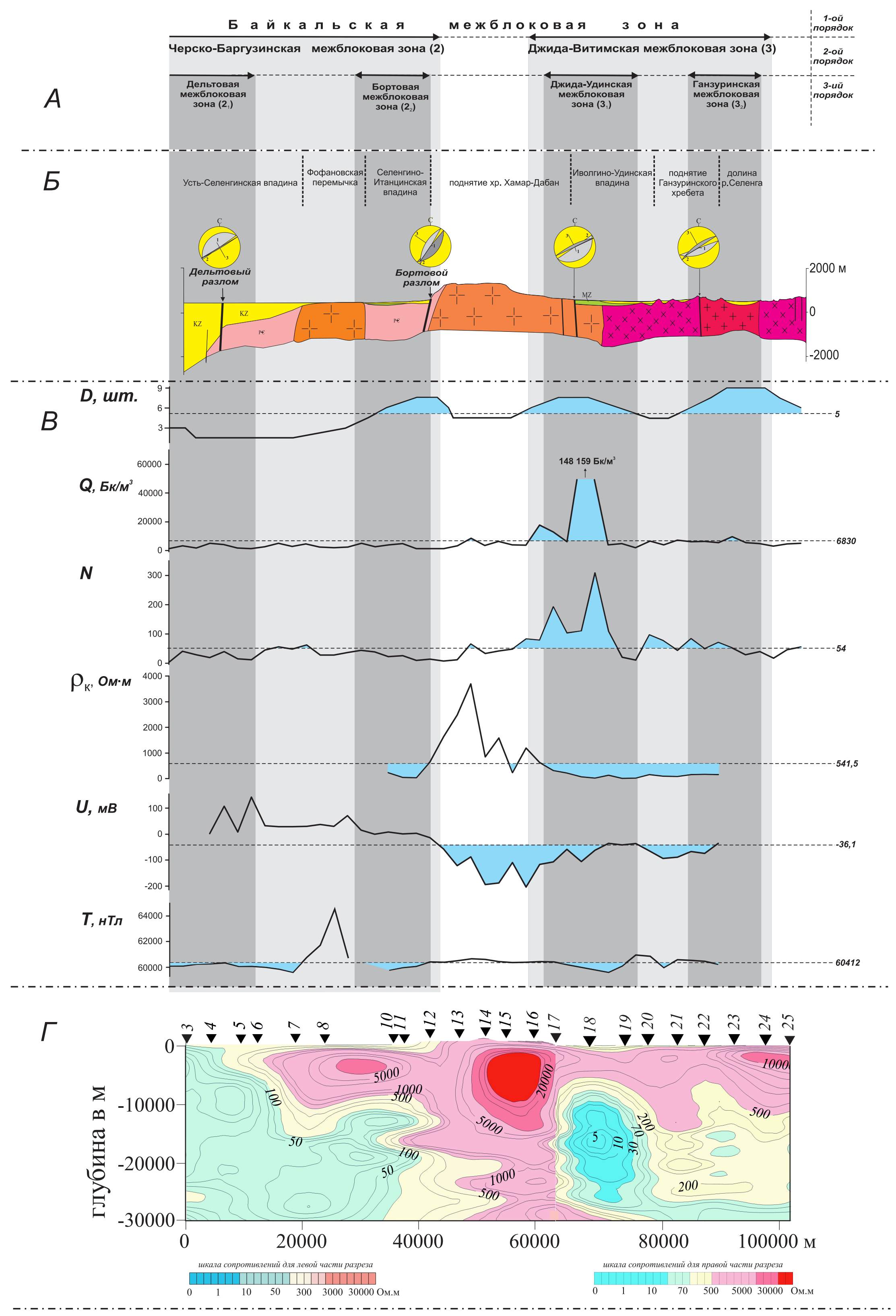

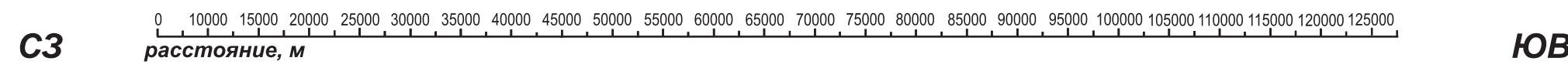

$$
\stackrel{\uparrow}{\uparrow}
$$

Тарбазатай

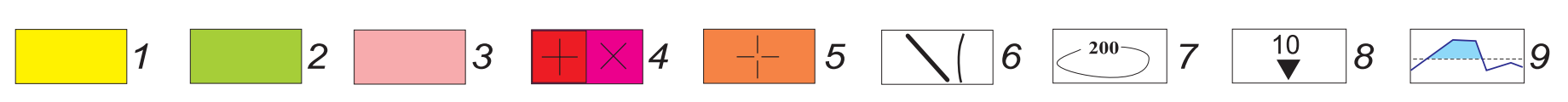

Рис. 11. Результаты геолого-структурных, геофизических и морфотектонических исследований на сегменте трансекта Кудара - Тарбагатай.

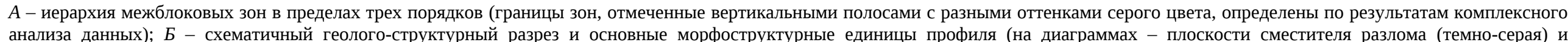

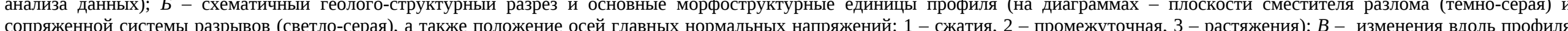

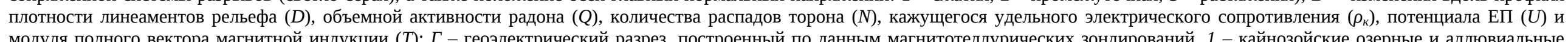

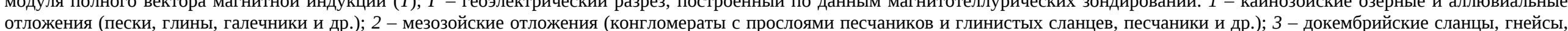
кристаллические известняки и доломиты; $4-5$ - интрузии гранитов и сиенитов палеозоя (4) и протерозойские граниты, граносиениты, гранодиориты, сиениты, диориты и диоритовые

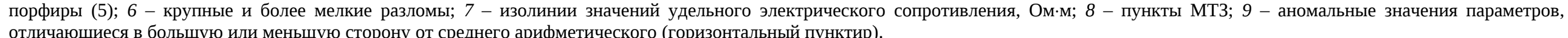

Fig. 11. Results of structural, geophysical and topography studies of the Kudara-Tarbagatay transect's segment.

A - the hierarchy of interblock zones within the three orders of magnitude (boundaries of the zones, which are marked by vertical stripes in different shades of grey, were determined from results of the

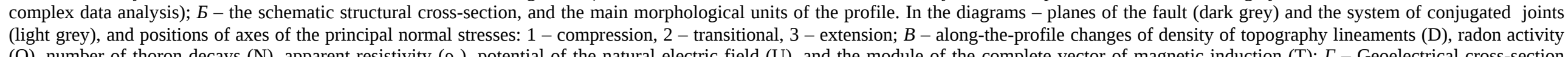
according to magnetotelluric sounding data. 1 - the Cenozoic lacustrine and alluvial sediments (sand, clay, gravel etc). 2 - the Mesozoic sediments (conglomerates with sandstone and clayey shale interbeds, sandstone etc.); 3 - the Precambrian schist, gneiss, crystalline limestone and dolomite; $4-5$ - intrusions of the Paleozoic granite and syenite (4) and the Proterozoic granite, granosyenite, granodiorite, syenite, diorite and diorite porphyrite (5); 6 - large and smaller faults; 7 - isolines of resistivity, ohm-m; 8 - MT sites; 9 - anomalous values of the parameters (smaller or larger than the mean arithmetic 
b

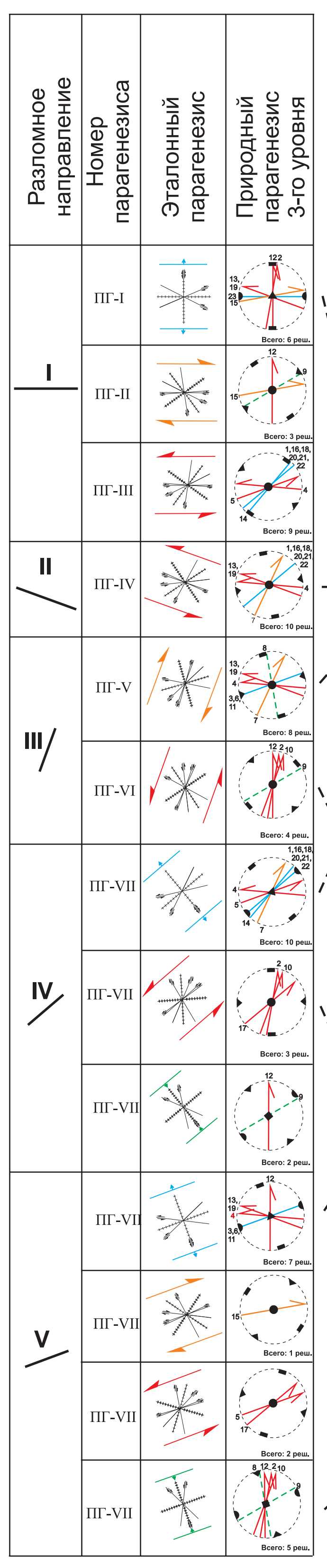

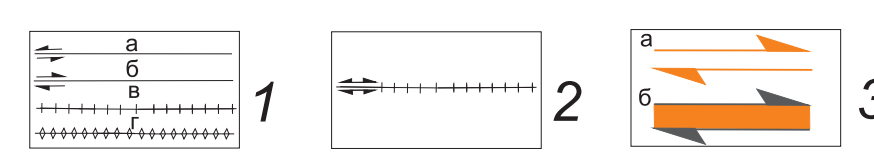

4

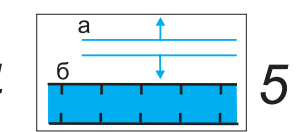

$\frac{a}{\frac{a}{2}} 7 \sqrt{\frac{a}{6-3}} 8$

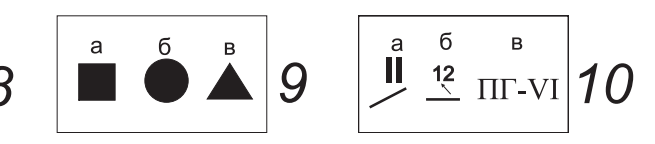

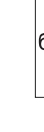

$\frac{1}{2 \cdots} 6$
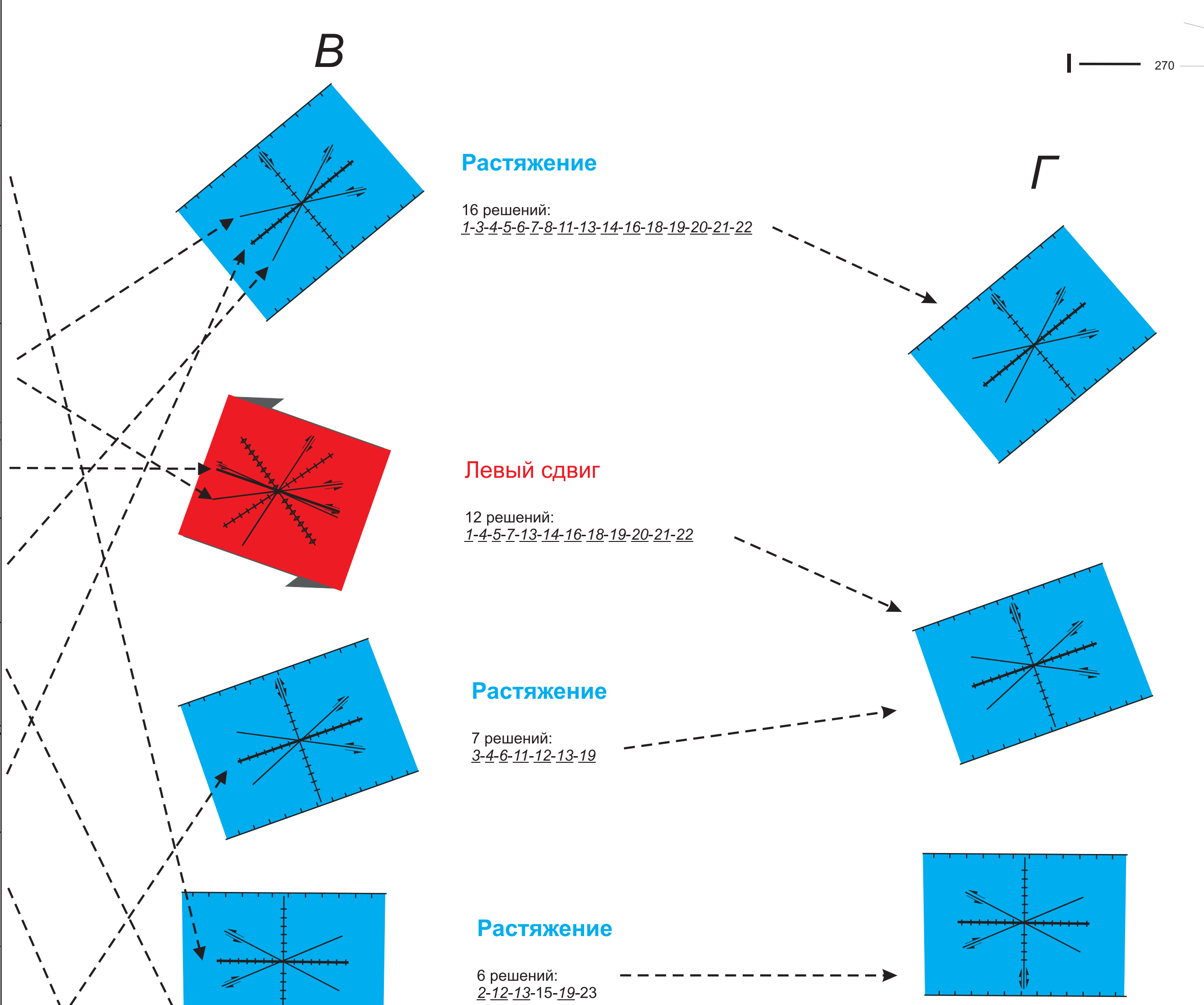

6.

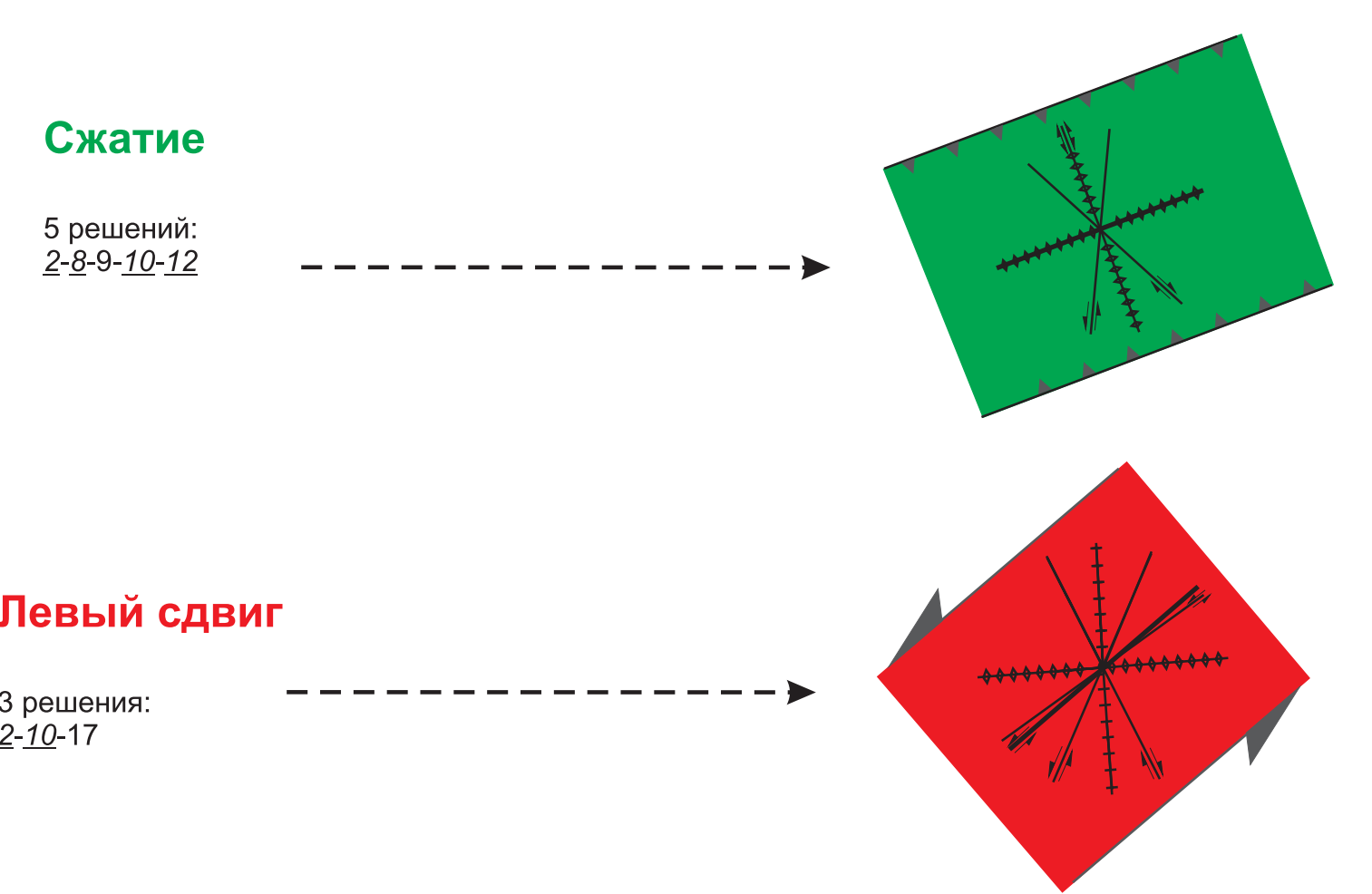

Растяжение

6 решени

$1-3-4-5-6-7-11-12-13-14-16-18-19-20-21-22-33 \%$

\section{6 решений:}

$1-3-4-5-6-7-8-11-13-14-16-18-19-20-21-22-33 \%$

\section{Растяжение}

6 решений:

2-12-13-15-19-23

Сжатие

5 решений:

2-8-9-9-10-12 -

$12 \%$

Левый сдвиг

2-10-17 -

Рис. 12. Результаты структурно-парагенетического анализа разрывов Джида-Удинской зоны, проведенного на основе наблюдений в окрестностях трансекта. A - роза-диаграммма простираний разнотипных зон скальвания, реконструированных в результате структурно-парагенетического анализа трецинных сетей в отдельных коренных выходах; 5
- результаты синтеза парагенезисов разрывных структур, существование которых на изученном участке принципиально возможно для пяти выделенных по розе-диаграмме разломных направлений; $B-\Gamma$ - парагенезисы разрывных структур, относящихся к двум смежным рангам регионального уровня. 1 - система разрывных структур с левосдвиговым (а), правосдвиговым (б), сбросовым (в) и взбросовым (г) перемещением крыльев; 2 - системы разрывов одинаковой ориентировки, но с разным характером перемещения крыльев; 3-6- зоны разломов локального

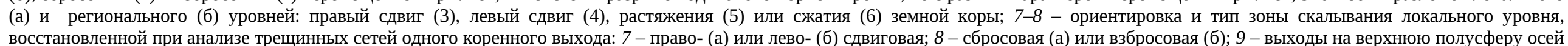

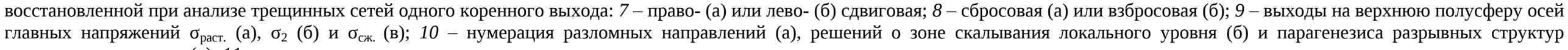

Fig. 12. Results of the paragenetic analysis of fractures in the Dzhida-Uda zone based on observation data collected in the vicinity of the transect.

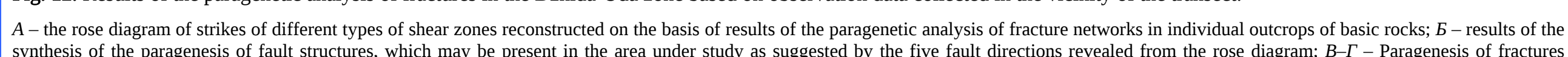
belonging to the two neighbouring ranks of the regional level. 1 - the system of fractures with left-side (a), right-side (6), normal (B) and reverse (r) displacements of the wings; 2 - systems of fractures of

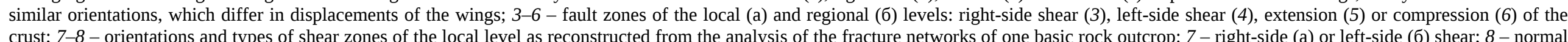

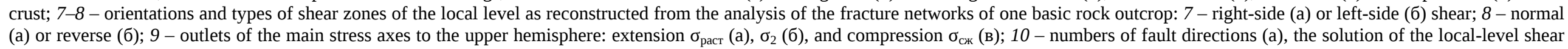
zone (б), and paragenesis of the regional-level fault structures (B); 11 - analysis stages. 
ся представительной в плане оценки объемной активности радона и торона, поскольку тонкодисперсные осадки дельты р. Селенга снижают возможность выхода газов к поверхности (рис. $11, B$ ), что в целом подтверждает выводы предшественников, изучавших потоки почвенного радона над разломами Усть-Селенгинской депрессии [Plyusnin et al., 2009]. В противоположность этому в пределах оставшегося отрезка профиля нами были зафиксированы самые высокие для трансекта значения концентрации почвенных радона $\left(148159\right.$ Бк/ $\left.\mathrm{M}^{3}\right)$ и торона. Участок их проявления имеет на профиле длину 15 км и ассоциируется с ДжидаУдинской разломной зоной, отделяющей хр. ХамарДабан от Иволгинской впадины. Источник подземных вод - «Халютинский Аршан», располагающийся в пределах рассматриваемого участка, характеризуется одним из наиболее высоких содержаний растворенного радона (349 Бк/л) среди водопроявлений обширной территории Прибайкалья. Роль структурного фактора в формировании аномалии не вызывает сомнений, поскольку в пределах заверочного профиля эманационной съемки, располагающегося в 20 км северо-восточнее трансекта (рис. 13), зона разлома также выделилась отрезком аномальных значений объемной активности радона. При этом максимальное значение параметра $Q\left(\approx 12000 \mathrm{Бk} / \mathrm{m}^{3}\right)$ соизмеримо с экстремумами, зафиксированными у северо-западной границы Байкальского рифта на сегменте трансекта Шертой - Крестовский (см. рис. 6, В). Эманационная аномалия протягивается далее на северо-восток, где разломная зона отделяет Удинскую впадину от хр. Улан-Бургасы. Материалы предшественников [Chernykh, Astakhov, 1981; Plyusnin et al., 2009] свидетельствуют, что причиной формирования радоновых вод на рассматриваемом участке являются эманирующие коллекторы в зонах разломов, оперяющих Джидино-Витимский шов, который нарушает породы с высоким содержанием радиоактивных элементов.

Опыт интерпретации разнородных геофизических данных на сегменте Шертой - Крестовский позволяет считать, что выявленная по вариациям рассматриваемых параметров неравномерность деструкции земной коры свидетельствует о существовании в центральной части профиля слабонарушенного блока (хр. ХамарДабан), ограниченного с обеих сторон межблоковыми зонами трансрегионального уровня (см. рис. 11). Эти зоны представлены Черско-Баргузинской и ДжидаВитимской разломными системами, для которых в отличие от блока характерны аномально низкие удельное сопротивление пород (в т.ч. и на глубине) и модуль полного вектора магнитной индукции, а также высокие значения объемной активности радона и количества распадов торона. Системы не выделяются экстремально низкими величинами потенциала ЕП, так как, по-видимому, не содержат протяженных (для выделения при профильной съемке рассматриваемого масштаба) участков распространения высокопроводя- щих пород. Как следствие, самые низкие значения параметра $U$ характерны для гипсометрически поднятого блока хр. Хамар-Дабан, где они связаны со сравнительно интенсивным нисходящим потоком метеорных вод.

Рассмотрение наряду с вариациями геофизических параметров результатов анализа геолого-структурных и морфотектонических наблюдений, представленных выше, позволяет установить особенности внутреннего строения выделенных разломных систем, относящихся к региональному уровню (см. рис. $11, A-Б)$. Обе они состоят из двух периферийных разломных зон и сравнительно массивного блока в центральной части, который в Черско-Баргузинской системе приурочен к Фофановской перемычке, а в Джида-Витимской системе - к Ганзуринскому хребту. Региональные межблоковые зоны в системе, представляющей борт Байкальской впадины, в параметрах близповерхностных геофизических полей практически не выделяются по разным причинам, главной из которых является осложняющее влияние осадков дельты р. Селенга. Однако в данном случае это не имеет принципиального значения, так как существующие геолого-структурные, морфотектонические и геоморфологические признаки, в совокупности с особенностями распределения землетрясений и удельного электрического сопротивления на глубине, а также данными предшественников [Solonenko, 1968; Zhirova et al., 1993; Morozova et al., 1999], позволяют вполне определенно выделить границы межблоковых зон. Их главные сместители Дельтовый и Бортовой разломы - являются в рассматриваемом регионе известными рифтообразующими сбросами, наклоненными в сторону оси Байкальского рифта [Rezanov et al., 2004]. Вследствие вертикальных перемещений в сотни метров образовались УстьСеленгинская и Селенгино-Итанцинская впадины, являющиеся выражением межблоковых зон в современном рельефе.

Ключевыми элементами двух региональных межблоковых зон, входящих в состав Джида-Витимской разломной системы, являются Джида-Удинский и Ганзуринский разломы, с подвижками по которым связаны понижения в рельефе - Иволгино-Удинская впадина и долина, которую здесь сформировала р. Селенга (см. рис. 11, А-Б). Объективность выделения рассматриваемых межблоковых зон в этой юго-восточной половине профиля подтверждается закономерными вариациями таких параметров, как плотность спрямленных элементов рельефа, объемная активность радона, количество распадов торона и потенциал ЕП (см. рис. $11, B)$. Кроме того, зоны отчетливо проявлены на геоэлектрическом разрезе участками пониженного сопротивления (см. рис. 11, Г: пункты МТ3-18 и 19, а также MT3-22 и 23), характеризующимися наклоном на юговосток, что совпадает с положением плоскостей Джида-Удинского и Ганзуринского разломов, определенным по геолого-структурным данным на поверхности 

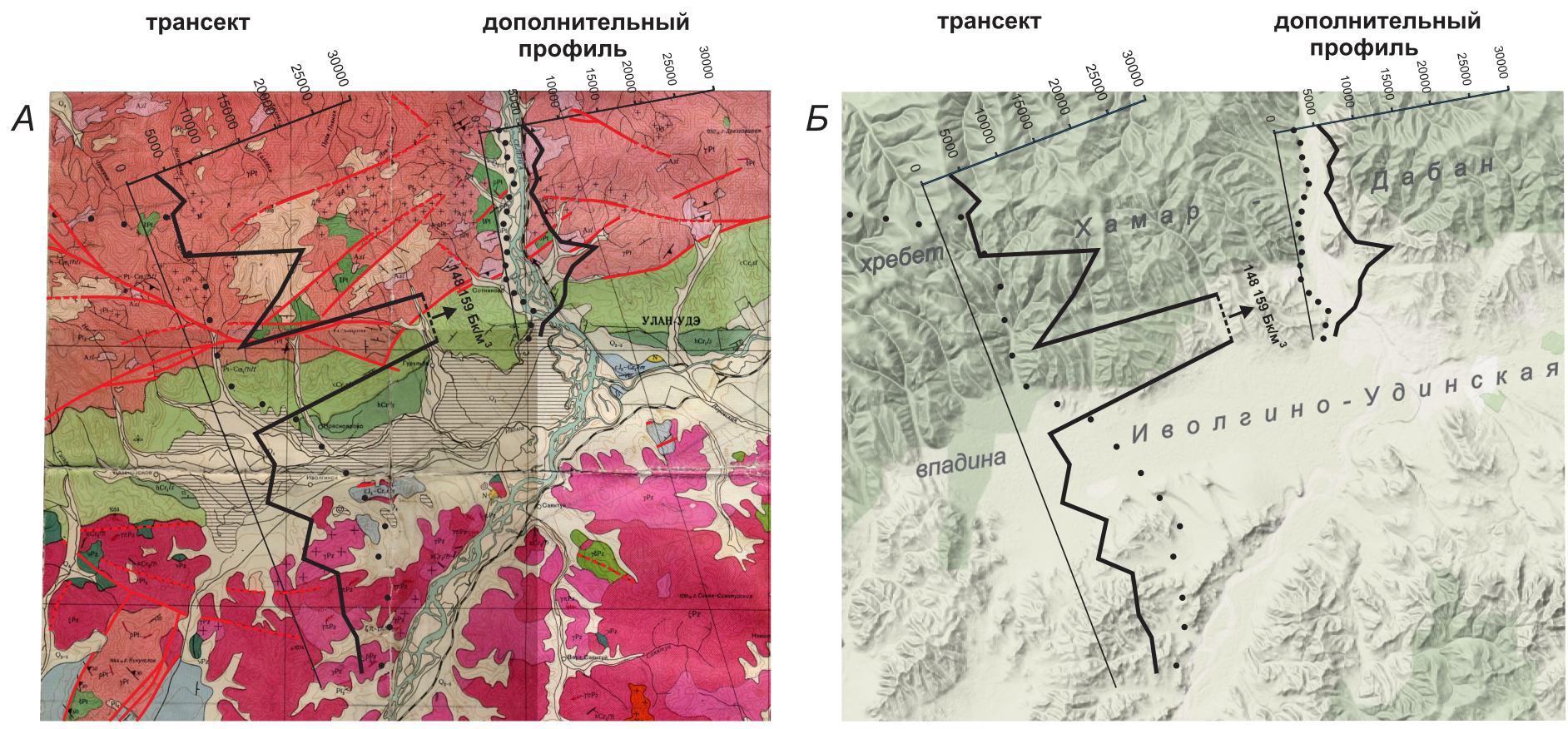

Рис. 13. Графики вариаций объемной активности радона (Бк/м³) вдоль пересекающих Джида-Удинскую разломную зону трансекта и дополнительного профиля, размещенные на фрагменте Государственной геологической карты масштаба 1:200000 (А) и трехмерной модели рельефа (Б).

Разным цветом показаны площади, занимаемые разнотипными горными породами региона, красными линиями - разломы, черными точками - пункты измерений концентраций почвенного радона.

Fig. 13. Curves showing variations of radon activity $\left(\mathrm{Bq} / \mathrm{m}^{3}\right)$ along the Dzhida-Uda transect and additional profiles across the fault zone, which are shown in a fragment of the State Geological Map (1:200000 scale) $(A)$ and in the 3D topography model $(5)$.

Areas of rocks varying in types are shown in different colours; red lines show faults; black circles show soil radon concentration measurement sites.

(см. рис. 11, Б).

Таким образом, трансрегиональный уровень зонноблоковой структуры земной коры на профиле Кудара Тарбагатай представлен тремя элементами: ЧерскоБаргузинской и Джида-Витимской разломными системами, а также находящимся между ними Хамардабанским блоком (см. рис. 11, А). Последний можно считать эталоном среди пересеченных трансектом элементов рассматриваемого типа, так как он однозначно выделяется во всех изученных геолого-геофизических полях. Это, во-первых, высокое гипсометрическое положение и, соответственно, низкий потенциал естественного электрического поля и, во-вторых, относительная монолитность и обусловленная этим низкая проницаемость для воды и газов, проявляющаяся в слабых эманациях радона и торона, повышенных значениях модуля полного вектора магнитной индукции, а также высоких величинах удельного электрического сопротивления пород во всем изученном здесь разрезе земной коры. Разломные системы, ограничивающие Хамардабанский блок, выделяются по комплексу признаков, причем некоторые из аномалий (например, концентраций почвенных радона и торона) имеют самую высокую интенсивность из выявленных на тран- секте. Согласно данным комплексного анализа геолого-геофизических полей, каждая из систем на региональном уровне состоит из двух крупных сбросовых зон и блока между ними. При однотипном зонноблоковом строении и развитии в условиях единой обстановки растяжения земной коры они имеют существенное отличие: региональные разломные зоны и Черско-Баргузинская система в целом наклонены на северо-запад, а Джида-Витимская система и составляющие ее межблоковые зоны характеризуются противоположным падением.

\subsection{4. Сегмент Тарбагатай - Красный Чикой}

На крайнем юго-восточном сегменте трансекта проведены геолого-геофизические съемки теми методами, которые оказались наиболее эффективными при выделении межблоковых зон на трансрегиональном уровне. $\mathrm{K}$ ним относятся геолого-структурные наблюдения за разломами и трещиноватостью в обнажениях горных пород, дистанционное и полевое изучение рельефа, а также эманационная съемка и магнитотеллурические зондирования в качестве инструментов для исследования, соответственно, близповерхностных и глубинных 

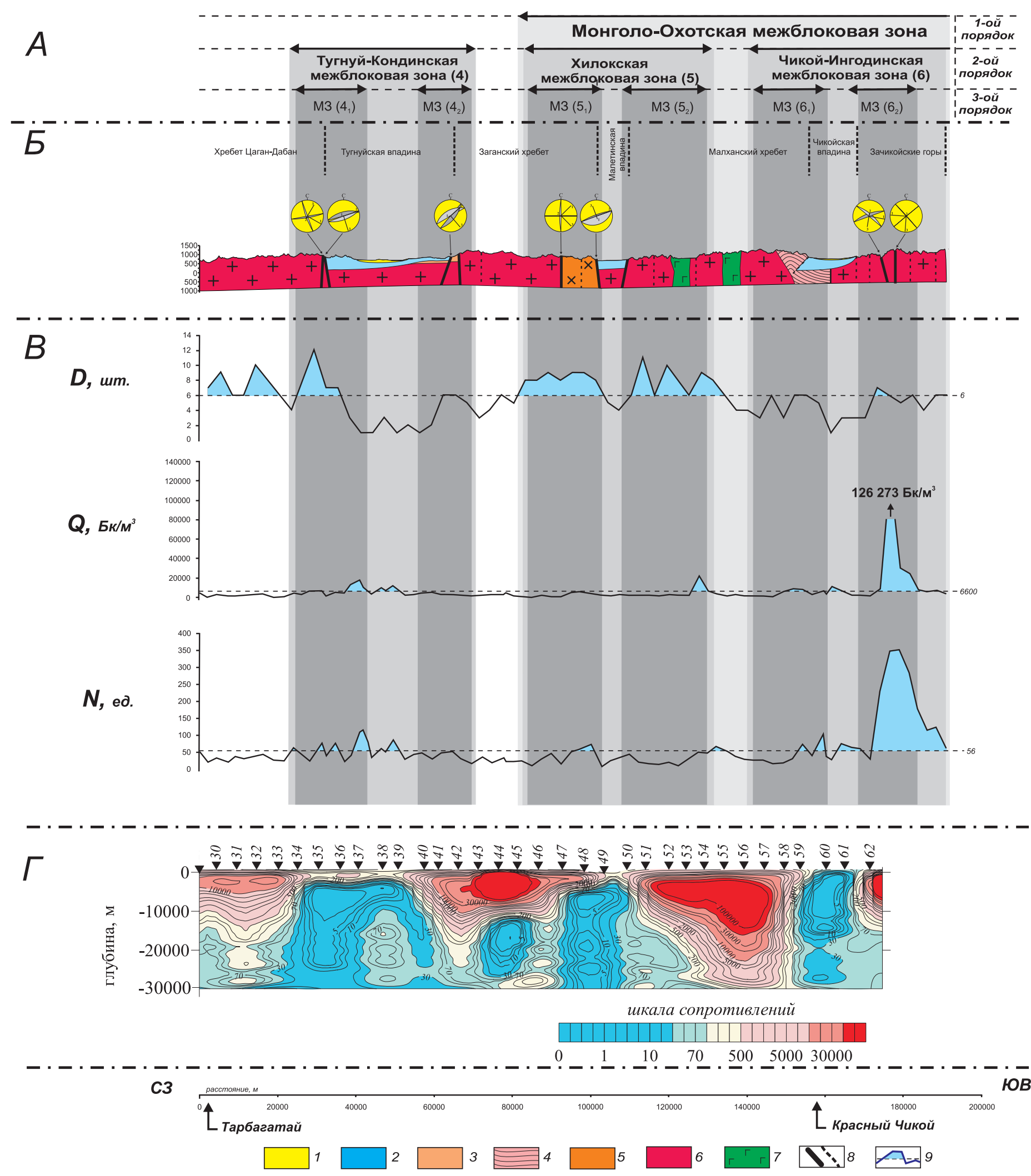

геофизических полей в земной коре. Интерпретация полученных материалов (рис. 14) показала, что использованный комплекс методов в данном случае менее эффективен для выявления границ разломных систем и их иерархической соподчиненности, чем это характерно для уже описанных сегментов трансекта. В какой-то мере полученный результат обусловлен не- достатком сведений о естественном электрическом и магнитном полях, однако главной причиной является существенно меньшая тектоническая активность региона по сравнению с изученной ранее областью современного рифтообразования, что отразилось на контрастности проявления межблоковых зон в некоторых природных полях. 
Рис. 14. Результаты геолого-структурных, геофизических и морфотектонических исследований на сегменте трансекта Тарбагатай - Красный Чикой.

$A$ - иерархия межблоковых зон в пределах трех порядков (границы зон, отмеченные вертикальными полосами с разными оттенками серого цвета, определены по результатам комплексного анализа данных); Б - схематичный геолого-структурный разрез и основные морфоструктурные единицы профиля (на диаграммах - плоскости сместителя разлома (темно-серая) и сопряженной системы разрывов (светло-серая), а также положение осей главных нормальных напряжений: 1 - сжатия, 2 - промежуточная, 3 - растяжения); $B$ - изменения вдоль профиля плотности линеаментов рельефа $(D)$, объемной активности радона $(Q)$ и количества распадов торона $(N) ; \Gamma-$ геоэлектрический разрез, построенный по данным магнитотеллурических зондирований. 1 - кайнозойские аллювиально-озерные отложения (пески, глины, галечники и др.); 2 - мезозойские вулканогенно-осадочные отложения (конгломераты, песчаники, алевролиты, базальтовые порфириты, туфы, фельзит-порфиры и др.); 3 - позднепалеозойские осадочно-вулканогенные породы (фельзит-порфиры, туфы, туфопесчаники, туфоконгломераты, туфогенные алевролиты и т.п.); 4 - докембрийские кристаллические сланцы, гнейсы, кристаллические известняки; 5 - мезозойские интрузии граносиенитов; 6-7 - палеозойские интрузии гранитов (6) или габбро-диоритов (7); 8 - крупные и более мелкие разломы; 9 - аномальные значения параметров, отличающиеся в большую сторону от среднего арифметического (горизонтальный пунктир).

Fig. 14. Results of geological structural, geophysical and morphological studies of the Tarbagatay-Krasny Chikoy transect's segment.

$A$ - the hierarchy of interblock zones within the three orders of magnitude (boundaries of the zones, which are marked by vertical stripes in different shades of grey, were determined from results of the complex data analysis); $\overline{-}$ - the schematic structural cross-section, and the main morphological units of the profile. In the diagrams - planes of the fault (dark grey) and the system of conjugated joints (light grey), and positions of axes of the principal normal stresses: 1 - compression, 2 - transitional, 3 - extension; $B$ - along-the-profile changes of density of topography lineaments (D), radon activity (Q), and number of thoron decays (N); $\Gamma$ - geoelectrical cross-section according to magnetotelluric sounding data. 1 - the Cenozoic lacustrine and alluvial sediments (sand, clay, gravel etc.); 2 - the Mesozoic volcanic-sedimentary deposits (conglomerate, sandstone, siltstone, basalt porphyrite, tuff, felsite porphyrite etc.); 3 - the Late Paleozoic sedimentary volcanic rock (felsite porphyrite, tuff, tuff sandstone, tuff conglomerate, tuffaceous siltstone etc.); 4 - the Precambrian crystalline schist, gneiss, crystalline limestone; 5 - the Mesozoic intrusions of granosyenite; $6-7$ - the Paleozoic intrusions of granite (6) or gabbro-diorite (7); 8 - large and smaller faults; 9 - anomalous values of the parameters (smaller or larger than the mean arithmetic values, i. e. - horizontal dashed line).

Вместе с тем геолого-структурные и морфотектонические методы позволили получить вполне определенные результаты, которые с учетом опыта исследований на более северо-западных сегментах трансекта дали возможность выявить разноранговые нарушенные зоны и относительно массивные блоки на отрезке Тарбагатай - Красный Чикой (рис. 14, Б). Блокам соответствуют вытянутые в северо-восточном и субширотном направлениях относительно поднятые участки рельефа: хребет Цаган-Дабан, Заганский и Малханский хребты, а также Зачикойские горы. Они представлены магматическими и метаморфическими образованиями палеозоя, включая Заганский комплекс метаморфического ядра, согласно Е.В. Склярову и др. [Sklyarov et al., 1997; Mazukabzov et al., 2011]. Ядра отделены от покровных вулканогенно-осадочных образований верхнего палеозоя и мезозоя пологой зоной милонитов, образовавшейся в условиях северо-запад юго-восточного растяжения. Покровный комплекс и зона милонитов в дальнейшем претерпели хрупкие деформации при растяжении в пределах крутопадающих зон разрывов и повышенной трещиноватости. Кроме того, существует мнение о том, что блоковое строение Забайкалья сформировалось в результате активизации долгоживущих глобальных и региональных дизъюнктивных структур северо-восточного простирания [Ochirov, 1976; Bulgatov et al., 1978], которые по геофизическим данным характеризуются субвертикальным или крутопадающим положением в разрезе земной коры и распространяются до значительных глубин (20-75 км).
Наши исследования показали (рис. 14), что в каждой из впадин новейшие разломы нарушают оба борта, оперяются нарушениями 2-го порядка и, таким образом, по аналогии с уже описанными региональными межблоковыми зонами, представляют внутреннюю структуру разломных систем: Тугнуй-Кондинскую, Хилокскую и Чикой-Ингодинскую (рис. 14, A). Данное предположение подтверждает анализ типов тензоров напряжений, реконструированных для региональных разломных зон в нескольких точках и отраженных в виде преобладающих решений на представленном геолого-структурном разрезе (рис. 14, Б). Кроме характерной для впадин обстановки поперечного растяжения, в зонах прибортовых дизъюнктивов реконструирован режим правосдвиговых перемещений (с учетом парагенетически связанных движений по крупным разломам $R$-типа). Это отличает данный регион от Байкальской межблоковой зоны, где, кроме доминирующих современного растяжения и древнего сжатия, отчетливо реконструируется обстановка левосдвиговых перемещений по разломам северо-восточной ориентировки. На данном этапе исследований можно предположить, что Хилокская и Чикой-Ингодинская системы являются составляющими Монголо-Охотской межблоковой структуры глобального уровня иерархии [Seminskii, 2008], так как на схеме зонно-блокового строения региона (см. рис. 2, Б) юго-западнее трансекта эти системы сочленяются друг с другом.

Положение границ межблоковых зон определялось на основе распределений количественных параметров, представленных на рис. $14, B-\Gamma$. График изменения 
плотности линеаментов рельефа $D$ являлся опорным для выделения межблоковых зон регионального уровня, тогда как эманационные параметры $(Q, N)$ и удельное электрическое сопротивление дополняли эти оценки на отдельных участках. Однако по большому счету параметры рассматриваемых геофизических полей, как и для уже описанных ранее сегментов трансекта, позволяли фиксировать положение межблоковых зон главным образом трансрегионального уровня. При этом интенсивность выделенных аномалий для обеих групп параметров на рассматриваемом сегменте трансекта характеризуется высоким уровнем. Для эманационных параметров вторые (после ДжидаУдинской зоны) по интенсивности максимумы (126273 Бк/м ${ }^{3}$ для $Q$ и 352 распада для $N$ ) были зафиксированы для региональной разломной зоны в Зачикойских гоpax, a аномально низкие значения удельного электрического сопротивления трассируют на глубину каждую из разломных систем. Аномалия проводимости под Чикойской впадиной наиболее близка к поверхности, что, вероятно, согласуется с отмеченными выше, связанными с одноименной разломной системой экстремальными значениями параметров $Q$ и $N$. По ширине участков высокой проводимости выделяется аномалия Тугнуй-Кондинской системы, однако отражающиеся в разрезе большие размеры и специфичность формы данной структуры связаны с ее пересечением профилем под сравнительно острым углом (см. рис. 2), а не с высокой тектонической активностью недр.

Таким образом, проведенные в пределах крайнего юго-восточного сегмента трансекта исследования показали, что, несмотря на удаленность от области Байкальского рифта с высокой современной активностью, характер делимости земной коры принципиально не изменился. С наибольшей степенью достоверности на профиле Тарбагатай - Красный Чикой выделяются три межблоковые зоны трансрегионального уровня. Это Тугнуй-Кондинская, Хилокская и Чикой-Ингодинская разломные системы, представляющие собой наиболее нарушенные и проницаемые участки земной коры, выраженные в рельефе линейными депрессиями, а на глубине - участками высокой проводимости, для которых наиболее вероятной причиной образования является насыщенность коры флюидами и газами. Анализ геолого-структурных и морфотектонических материалов позволяет с большой долей уверенности сделать вывод о том, что каждая их трансрегиональных межблоковых зон на региональном уровне состоит из опущенного центрального блока и ограничивающих его бортовых разломных зон. Парагенетический анализ тектонических нарушений, составляющих внутреннюю структуру этих зон, свидетельствует, что наиболее отчетливо в описанной выше юго-восточной части трансекта проявлены подвижки сбросового и правосдвигового типа. В совокупности с ориентировкой, размерами, характером глубинного строения и другими дополнительными признаками можно предположить, что Тугнуй-Кондинская система нарушает блок между глобальными Байкальской и МонголоОхотской межблоковой зонами, причем последняя включает Хилокскую и Чикой-Ингодинскую системы трансрегионального уровня.

\section{$* * *$}

Общие закономерности строения межблоковых зон трансрегионального уровня могут быть сформулированы в нескольких положениях, являющихся результатом сопоставления особенностей их проявления в различных геолого-геофизических полях на отдельных сегментах трансекта Шертой - Красный Чикой.

1. Межблоковые зоны трансрегионального иерархического уровня представлены в литосфере юга Восточной Сибири разломными системами шириной от 40 до 60 км. Из семи пересеченных трансектом зон наибольшими поперечными размерами обладают Обручевская и Чикой-Ингодинская разломные системы, представляющие приосевые части Байкальской и Монголо-Охотской межблоковых структур, относящихся к следующему (глобальному) уровню иерархии.

2. Внутреннее строение разломных систем определяется сочетанием блоков и региональных разломных зон, закономерные пространственные соотношения которых зависят от динамической обстановки развития земной коры в позднекайнозойское время. В системах северо-западной половины трансекта эти региональные структуры являются зонами наклоненных на юго-восток (Обручевская, Джида-Витимская системы) или северо-запад (Черско-Баргузинская система) сбросов, которые развиваются в режиме растяжения литосферы. В трех системах юго-восточной части трансекта (Тугнуй-Кондинской, Хилокской и Чикой-Ингодинской) реконструированы растяжение и сдвиг. У подавляющего большинства изученных систем сдвига главными элементами строения являются две региональные разломные зоны и центральный блок, представляющий впадину в современном рельефе.

3. Межблоковые структуры трансрегионального уровня в целом и составляющие их региональные разломные зоны в частности характеризуются интенсивной нарушенностью и, как следствие, высокой проницаемостью для флюидов, что определяет их характерную выраженность в разнотипных геолого-геофизических полях. Вблизи поверхности разломные системы выделяются максимумами эманаций радона и торона, минимумами кажущегося удельного электрического сопротивления и, зачастую, модуля полного вектора магнитной индукции. Потенциал естественного электрического поля в пределах систем обычно характеризуется повышенными значениями, но существенно понижается, если в состав тектонитов входят проводящие минералы. На глубинах в первые десятки километров изученные разломные системы представлены широкими участками высокой электропроводности, в 
пределах которых могут обособляться региональные разломные зоны с аномально низким удельным электрическим сопротивлением (до 0.5 Ом·м).

4. Закономерная выраженность разломных систем в геофизических полях осложняется действием факторов, главными из которых являются характер динамической обстановки (интенсивность и направленность внешних сил), а также состояние деформируемого субстрата (состав и реологические свойства). Особенно важен первый фактор, так как он определяет структуру межблоковой зоны, т.е. степень неравномерности ее разломного строения, а значит, и интенсивность действия на разных участках сопутствующих процессов (флюидизации, накопления осадков, выветривания, эрозии и др.), что и обусловливает конкретные формы проявления разломной системы в том или ином геофизическом поле.

\section{4. МЕЖБЛОКОВЫЕ ЗОНЫ ГЛОБАЛЬНОГО УРОВНЯ, ВЫДЕЛЯЮЩИЕСЯ ПО КОМПЛЕКСУ ГЕОЛОГО- ГЕОФИЗИЧЕСКИХ ПРИЗНАКОВ НА ТРАНСЕКТЕ ШЕРТОЙ - КРАСНЫЙ ЧИКОЙ}

Как следует из результатов предыдущих исследований зонно-блоковой структуры Центральной Азии [Seminsky, 2001; Seminskii, 2008], трансект охватывает две межблоковые зоны глобального ранга: Байкальскую и Монголо-Охотскую. Задачей представленных в данном разделе исследований было установить, какие разломные системы входят в каждую из этих зон и, таким образом, определить пространственные границы элементов зонно-блоковой структуры на глобальном уровне иерархии. Данная задача решается ниже сначала путем анализа близповерхностных геолого-геофизических полей, а затем на базе изучения глубинного геоэлектрического разреза. Для удобства рассмотрения в обоих случаях материалы съемок, проведенных в пределах отдельных сегментов, были объединены для всего трансекта (рис. 15, 16). При этом из малоглубинных исследований к анализу привлечены результаты методов (см. рис. 15, Г-Ж), которые при рассмотрении отдельных сегментов были наиболее эффективны для выделения межблоковых зон (распределение УЭС, данные о положении и морфогенетическом типе крупных разломов, вариации высоты рельефа и концентрации почвенного радона), а также дополнительные материалы из литературы (см. рис. $15,5-B)$, свидетельствующие об их активности на современном этапе тектогенеза (распределение теплового потока и суммарной энергии землетрясений). В основу изучения глубинного строения были положены результаты только одного геофизического метода - МТЗ, но для их углубленного анализа использовались разные способы представления данных (рис. 16, $B-\Gamma$ ).

Из глобальных межблоковых структур главным объектом комплексных исследований являлась Байкальская рифтовая зона, которая в центральной части пересечена трансектом полностью (см. рис. 15). Ее западное плечо представлено Обручевской разломной системой, состоящей из трех региональных межблоковых зон, у которых ключевыми элементами являются крупнейшие сбросы Прибайкалья (Прихребтовый, Приморский и Морской), наклоненные в сторону оси рифта. Восточный борт Байкальской впадины представлен Черско-Баргузинской разломной системой с Дельтовой и Бортовой сбросовыми зонами, падающими в противоположную сторону. Эти традиционно выделяемые элементы рифта попадают на линии трансекта в пределы главных максимумов логарифма суммарной энергии землетрясений с $\mathrm{K} \geq 7.7$, произошедших в период 1960-2005 гг., а также теплового потока, для которого график был построен с использованием карты из статьи [Duchkov et al., 1999]. Региональным разломным зонам, входящим в состав рассматриваемых систем, соответствуют повышенный выход радона (за исключением Морской зоны) и минимумы удельного электрического сопротивления (за исключением Приморской зоны).

Кроме того, полученные на трансекте Шертой Красный Чикой комплексные материалы свидетельствуют о необходимости включения в состав Байкальской межблоковой зоны Джида-Витимской разломной системы. В рельефе она выражена Иволгино-Удинской впадиной, днище которой располагается на одном уровне с пририфтовой Итанцино-Селенгинской депрессией и, таким образом, примерно на 250 м глубже Тугнуйской и, тем более, других аналогичных отрицательных форм поверхности, располагающихся юговосточнее (см. рис. 15, Д). Это является результатом рифтового растяжения в направлении СЗ-ЮВ, реализующегося на региональном уровне в двух бортовых сбросовых зонах (см. рис. 15, E), каждая из которых выделяется высокими концентрациями радона у поверхности и пониженными электрическими сопротивлениями на глубине (см. рис. 15, Г, Ж). Кроме того, Джида-Витимской разломной системе соответствуют отчетливые максимумы теплового потока и логарифма суммарной энергии землетрясений (см. рис. $15,5-B$ ), причем эти признаки современной активности процесса деструкции в ее пределах, согласно площадным материалам разных авторов [Suvorov, Tubanov, 2008; Klyuchevskii, Zuev, 2011; Seminskii, Radziminovich, 2011; Sherman, Zlogodukhova, 2011; Zherebtsov, 2012], трассируются на северо-восток и юго-запад от трансекта. Судя по амплитудам перемещений, сейсмической активности, величинам теплового потока, активности эрозионных процессов и другим показателям, интенсивность деструкции здесь ниже, чем в Обручевской и Черско-Баргузинской разломных системах, однако процесс протекает в сходных условиях деформирования земной коры. Таким образом, полученные материалы подтверждают взгляды тех исследователей, которые включают рассматриваемый регион в границы Байкальской рифтовой зоны [Levi, 


\begin{tabular}{|c|c|c|c|c|c|c|c|c|c|c|c|}
\hline 1-oü & Сибирский блок & & Байкальская & межблоковая & зона & & & айкальский бл & & Монголо-Охо & кая межблоковая зона \\
\hline 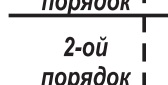 & 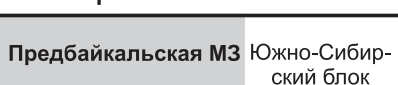 & Обручевская Мз & 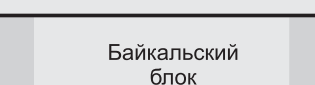 & Черско-Баргузинская м3 & 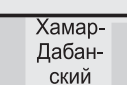 & Джида-Витимская М3 & 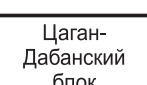 & Туггуй-кондинская М3 & 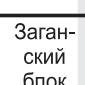 & Хилокская Мз & 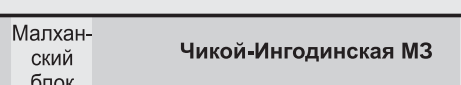 \\
\hline
\end{tabular}

LgIE 3-ий !
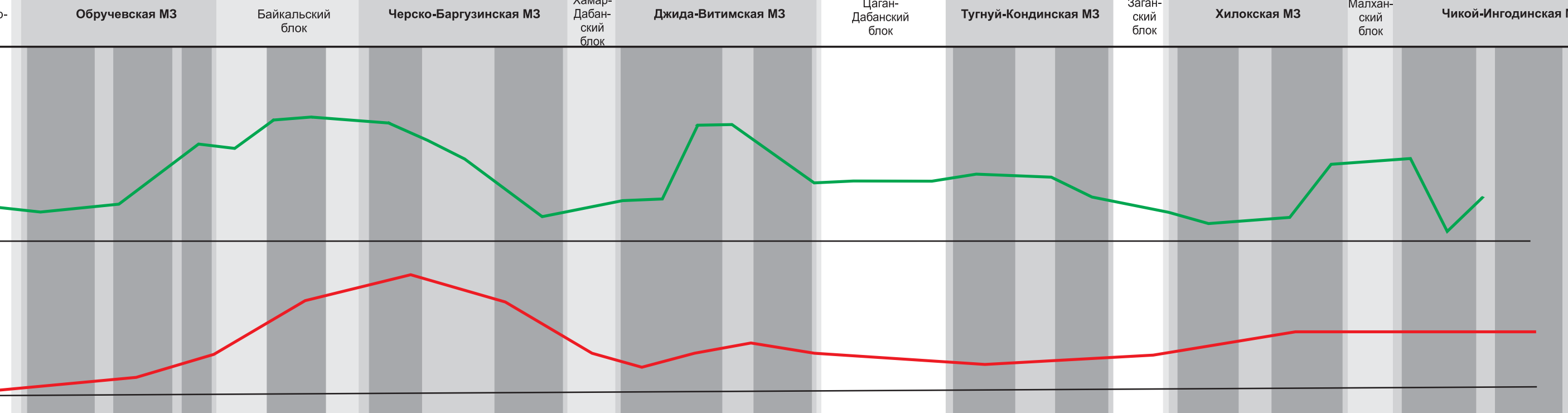

Б

$\overline{\mathbf{q}}, \mathrm{MBm} / \mathrm{M}^{2}$

Q, $5 \kappa / M^{3}$

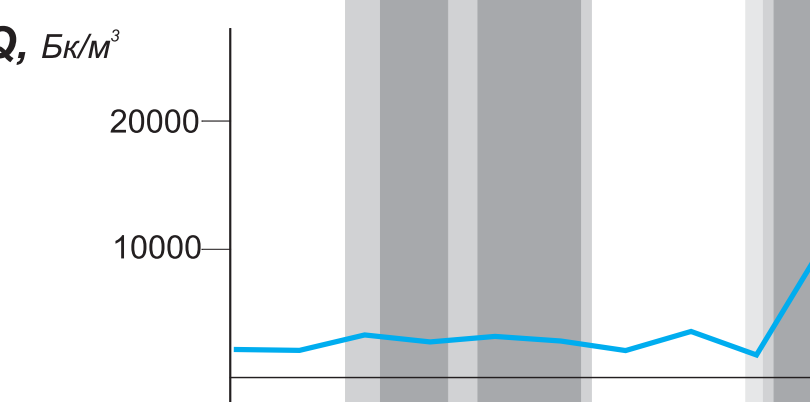

h, $M \quad 1350-$

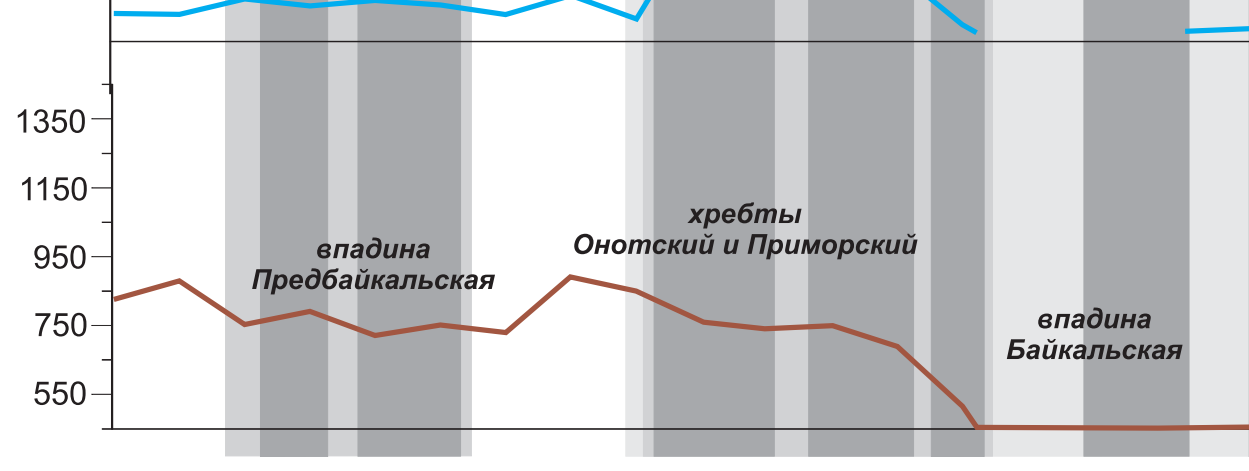

C3

(4)

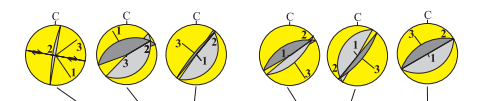

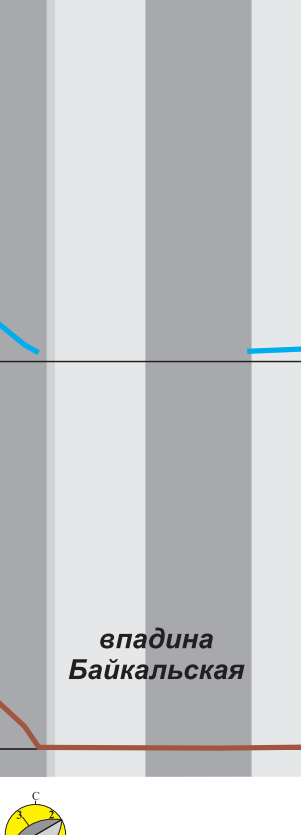

$2000 \mathrm{M}]$

7 कोण L-1- оз.Байкал

Q

8

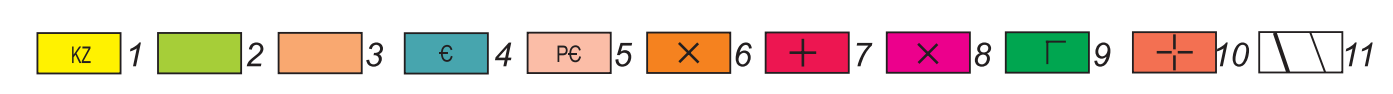

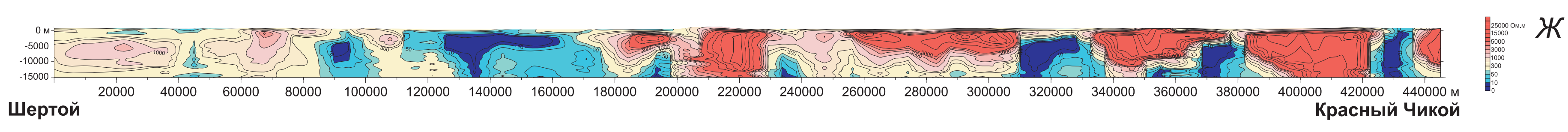

Рис. 15. Иерархия межблоковых зон, выявленная для верхней части земной коры при тектонофизической интерпретации результатов комплексных исследований вдоль трансекта Шертой - Красный Чикой.

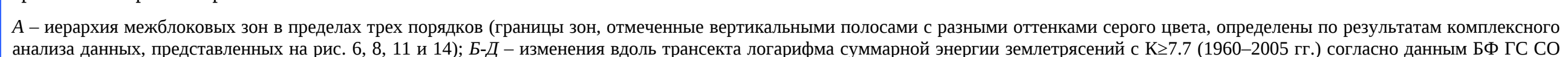

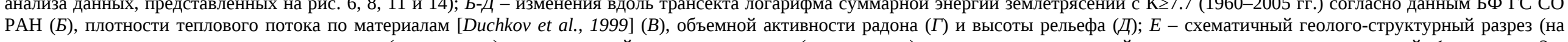

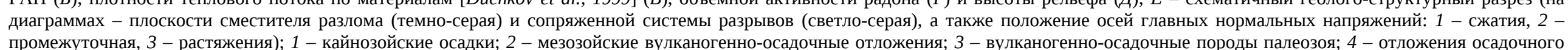

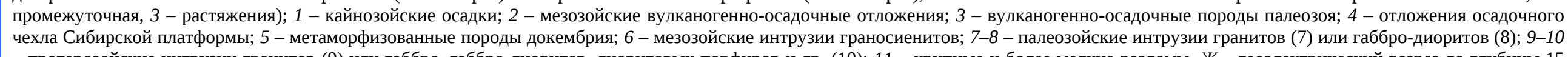

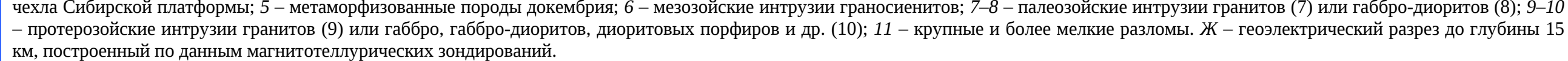

Fig. 15. The hierarchy of interblock zones in the upper crust according to tectonophysical interpretation of results of complex studies along the Shertoy-Krasny Chikoy transect.

$A-$ the hierarchy of interblock zones within the three orders of magnitude (boundaries of the zones, which are marked by vertical stripes in different shades of grey, were determined from results of the
complex analysis of data given in Figures $6,8,11$, and 14); $5-\not$ - along-the-transect changes of the logarithm of the total energy of earthuakes with $K \geq 7.7$ (from 1960 to 2005 ) according to data published by the Baikal Branch of the Geophysical Survey, Siberian Branch of RAS (E), heat flow density according to data from [Duchkov et al., 1999] (B), radon activity ( $(\Gamma)$, and elevations (I); $E-$ the schematic structural cross-section. In the diagrams - planes of the fault (dark grey) and the system of conjugated joints (light grey), and positions of axes of the principal normal stresses: 1 - compression,
2 - transitional, 3 - extension; $\$$ - the geoelectric profile to a depth of $15 \mathrm{~km}$, according to MT data. 1 - the Cenozoic sediments; 2 - the Mesozoic volcanic-sedimentary deposits; 3 - volcano-sedimen-

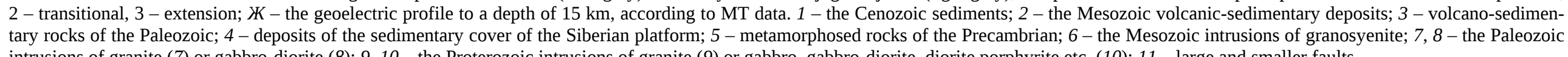




\begin{tabular}{|c|c|c|c|c|c|c|c|c|c|c|c|c|}
\hline $\begin{array}{l}\text { 1-pü } \\
\text { nорядок } 1\end{array}$ & Сибирский блок & & Байкальская & межблоковая & зона & & \multicolumn{3}{|c|}{ Забайкальский блок } & Монголо-Ох & кая м & блоковая зон \\
\hline \begin{tabular}{c|}
$2-0 и ̆$ \\
חорядок \\
\end{tabular} & $\begin{array}{l}\text { Предбайкальская Мз Южно-Сибир- } \\
\text { ский блок }\end{array}$ & Обручевская М3 & $\begin{array}{l}\text { Байкальский } \\
\text { бпок }\end{array}$ & Черско-Баргузинская МЗ & 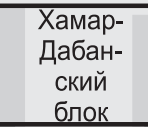 & Джида-Витимская М3 & $\begin{array}{l}\text { पаган- } \\
\text { Дабанскй } \\
\text { блок }\end{array}$ & Тугнуй-Кондинская МЗ & $\begin{array}{l}3 \text { 3аган- } \\
\text { crny } \\
6 \text { пок }\end{array}$ & Хилокская М3 & 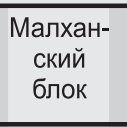 & Чикой-Ингодинская М3 \\
\hline $\begin{array}{c}\text { 3-ий } \\
\text { порядок } \\
1\end{array}$ & & & & & & & & & & & & \\
\hline
\end{tabular}

\section{h, м 2000 оз.Байкал}

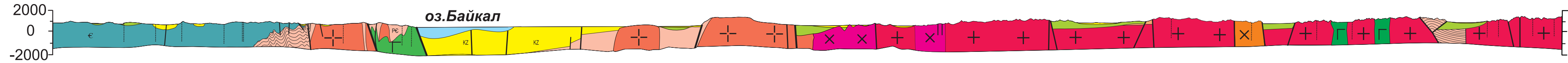

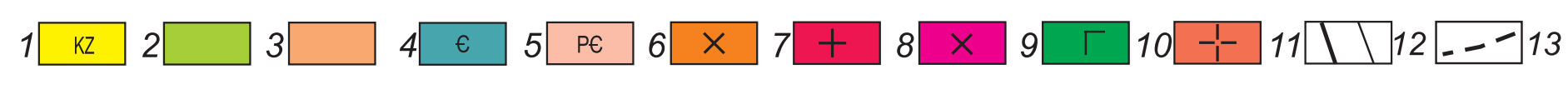
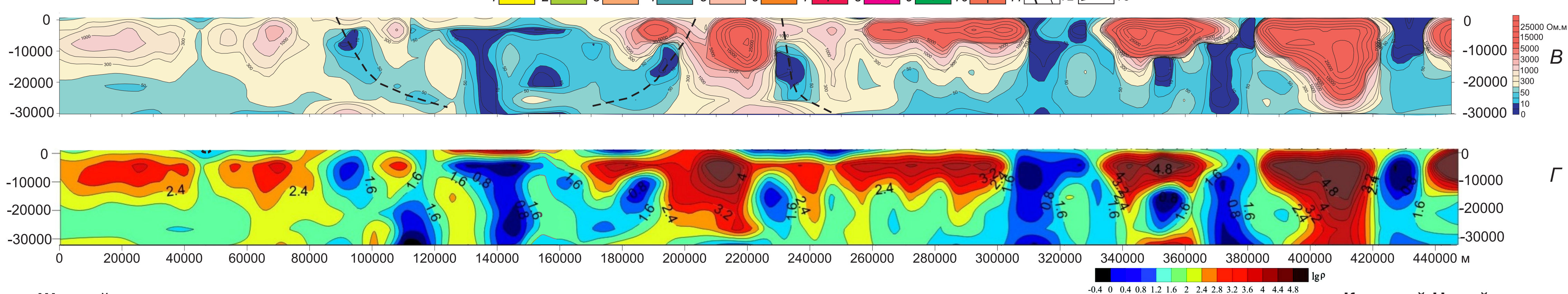

Шертой

Красный Чикой

Рис. 16. Проявление иерархии межблоковых зон в глубинном строении земной коры по трансекту Шертой - Красный Чикой.

А - иерархия межблоковых зон в пределах трех порядков (границы зон, отмеченные вертикальными полосами с разными оттенками серого цвета, определены по результатам комплексного
анализа данных, представленных на рис. $6,8,11,14$ и 15); 5 - схематичный геллого-струкуурный разрез: $1-12$ - см. на рис. 15; 13 - оси разломных зон, занимающцих периферийное

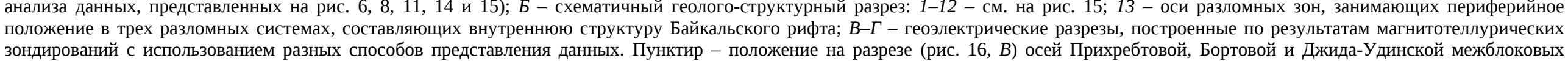
зондирований с
разломных зон.

Fig. 16. Manifestation of the hierarchy of interblock zones in the deep structure of the crust along the Shertoy-Krasny Chikoy transect.

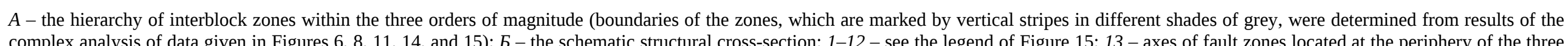

fault systems comprising the structure of the Baikal rift; $B-\Gamma$ - geoelectric profiles based on MT data. To construct the profiles, different data presentation methods were applied. Dotted lines show

tault systems comprising the structure of the Baikal rift; $B-\Gamma$ - geeelectric proffiles based on $\mathrm{MT}$ data. To construct the prof
positions of axes of the Prikhrebtovaya, Bortovaya and Dzhida-Uda interblock fault zones in the cross-section (see figure 16 B). 
1980; Popov, 1989; Yungsheng et al., 1996; Gol'din et al., 2006; San'kov et al., 2009; Seminskii, Radziminovich, 2011; and others], увеличивая ее поперечные размеры до 200 км.

Проявление Монголо-Охотской межблоковой зоны глобального уровня в приповерхностных геологогеофизических полях может быть рассмотрено только на примере ее северо-западной части, пересеченной трансектом. При этом граница зоны по имеющимся материалам не может быть проведена однозначно. Как уже отмечалось ранее, на данном этапе исследований к Монголо-Охотской зоне достаточно определенно относятся Чикойская и Хилокская разломные системы, которые характеризуются субвертикальным положением в пространстве, доминированием растяжения и проявлением правосдвиговых перемещений (см. рис. $15, E)$, высокими концентрациями почвенного радона и минимумами УЭС (см. рис. 15, Г, Ж), а также при имеющейся детальности измерений - единым максимумом плотности теплового потока (рис. 15, B). Кроме того, эти системы при рассмотрении в плане сливаются на юго-западе рассматриваемой территории в одну широкую зону (рис. 2, Б). Тугнуй-Кондинская система занимает обособленное пространственное положение, характеризуется, кроме сбросовых, правосдвиговыми перемещениями и, скорее всего, нарушает блок (Забайкальский), располагающийся между двумя соседними зонами глобального уровня (рис. $15, A$ ).

Сделанные по характеру приповерхностных геолого-геофизических полей выводы подтверждаются при анализе геоэлектрического разреза, построенного для трансекта до глубин в 30 км в разных видах (рис. 16, $B$ - распределение УЭС; рис. $16, \Gamma$ - распределение $\lg \rho_{\kappa}$ ). При этом полученные результаты уточняют геоэлектрическое строение области сочленения Сибирской платформы и Центрально-Азиатского складчатого пояса, охарактеризованное ранее по результатам проведения МТЗ в мелком масштабе. Единый проводящий коровый слой, поверхность которого, по данным предшественников [Popov, 1989], отмечалась на глубинах 22 км в платформенной области, 12 км - под оз. Байкал и 16-22 км - в Забайкалье, по результатам проведенных нами зондирований выделен лишь фрагментарно. Это в совокупности с проявлением субвертикальных и наклонных проводящих структур отчетливо отражает блоковый характер делимости земной коры, представленный, в частности, на материалах МТЗ М.Н. Бердичевским и др. [Berdichevsky et al., 1996, 1999]. В то же время описанная ниже специфика геоэлектрического разреза Шертой - Красный Чикой (рис. 16, B-Г) свидетельствует о правомерности использования введенного нами [Seminsky, 2001] термина «зонно-блоковая структура». Он акцентирует внимание на значимости флюидизированных зон, размеры которых в активной области сочленения платформы и складчатого пояса соизмеримы, а иногда и превышают размеры смежных блоков.
Как видно из рис. $16, B-\Gamma$, Байкальская межблоковая зона, имеющая по данным исследований вдоль трансекта близповерхностных геолого-геофизических полей ширину 200 км, выделяется на глубине как область в целом низких УЭС. На этом фоне имеют место полосы и цепочки минимумов сопротивления (0.5-10.0 Ом·м), распределение которых контролируется строением разломных систем, выделенных ранее. Это свидетельствует о справедливости представлений предшественников о флюидной природе аномалий проводимости [Popov, 1987; Berdichevsky et al., 1999], неотъемлемой составляющей которой является наличие проницаемых зон, представленных сетью сообщающихся разноранговых разрывов, включая мелкую повсеместно распространенную трещиноватость. Байкальская зона глобального уровня «прорывает» проводящий слой, фрагменты которого (с кровлей на глубине $\approx 15$ км) достаточно отчетливо фиксируются на платформе (отрезок трансекта 0-85 км) и в складчатом поясе (отрезок трансекта 260-360 км), маркируя блоки глобального уровня иерархии. Данные блоки также имеют зонно-блоковую структуру, но, судя по геоэлектрическому разрезу, ширина флюидизированных зон на каждом уровне иерархии существенно меньше по сравнению с соседними относительно монолитными участками коры. Это видно на примере Предбайкальской и Тугнуй-Кондинской разломных систем, представляющих собой широкие флюидизированные зоны, которые рассекают, соответственно, Сибирский и Забайкальский блоки на всю мощность. Кроме описанных структур трансрегионального уровня, сплошность блоков нарушают более мелкие зоны разломного типа, положение которых в рассматриваемом масштабе исследований маркируется подъемами кровли корового проводящего слоя, что ранее отмечалось предшественниками для более мелких структур в районе Усть-Селенгинской депрессии [Morozova et al., 1999]. Рассматриваемая черта геоэлектрического разреза особенно отчетливо видна на примере Забайкальского блока, где разломы более активны на современном этапе тектогенеза по сравнению с краевой частью платформы. При этом УЭС пород в пределах смежных слабонарушенных частей блоков достигают величин 1500 Ом·м в краевой части платформы и более 35000 Ом·м в Забайкалье, что в последнем случае связано с их представленностью магматическими комплексами с низкой проводящей спобабнбебянњном уровне изучения межблоковых зон проводящий коровый слой не фиксируется в виде единой структуры, что повторяет ситуацию, установленную ранее на основе данных МТЗ для Провинции Бассейнов и Хребтов [Park, Wernicke, 2003]. В пределах трансекта на глубинах, где слой был выделен предшественниками (см. выше), зачастую имеет место сужение субвертикальных и наклонных зон проводимости, а наиболее крупные блоки (Хамар-Дабанский в Байкальской зоне и Малханский в Монголо-Охотской зо- 
не) сохраняют высокое сопротивление (рис. 16, В). Зонно-блоковая структура, отражающаяся в поле УЭС, определяется характером взаимодействия литосферных блоков, что особенно отчетливо проявляется на примере Байкальской межблоковой зоны. Участки низких сопротивлений, маркирующие положение крупных разломных зон, преобладают по размерам над менее нарушенными блоками, а по взаимному расположению отвечают обстановке растяжения земной коры. В отличие от субвертикального положения в Монголо-Охотской зоне (косвенно свидетельствующего о сдвиговом режиме разломообразования), здесь доминируют наклонные структуры, причем некоторые из них выполаживаются с глубиной, что проявляется на геоэлектрических разрезах независимо от способов представления данных распределения УЭС (рис. 16, $B$ $\Gamma$ ). Изменение углов наклона особенно явно выражено начиная с глубины $\approx 20$ км, у краевых разломных зон, представляющих каждую из трех входящих в состав рифта разломных систем (см. пунктир на рис. 16, В): Прихребтовую для Обручевской системы, Бортовую для Черско-Баргузинской системы и Джида-Удинскую для Джида-Витимской системы. Данная особенность, впервые отчетливо установленная для Байкальского рифта по материалам детальных съемок МТЗ, характерна для структур, формирующихся при растяжении земной коры в других природных регионах, а также при воспроизведении процесса растяжения в экспериментах [Cloos, 1968; Logachev, 1992; McClay et al., 1992; Withjack et al., 1995; Bahroudi et al., 2003; Schreurs et al., 2006; and others]. Известный факт отсутствия для Байкальского рифта сейсмологических данных о разрядке упругих напряжений при подвижках по наклонным плоскостям может, в частности, объясняться приуроченностью пологих сместителей главным образом 1) к периферии зоны, где напряжения понижены, а также 2) достаточно глубоким уровням коры (более 20 км), где вследствие повышенных давлений, температур и флюидизации господствуют криповые подвижки по разломным поверхностям.

Сопоставляя представленные выше результаты с материалами предшественников по трансектам с близким пространственным положением [Zorin et al., 1994, 2002], следует отметить, что принципиальная картина делимости земной коры на низком уровне иерархии подобна. Крупным блокам, выделенным на трансекте Шертой - Красный Чикой, соответствуют террейны со специфическим набором вещественных комплексов, описанным в цитированных публикациях с позиций тектоники плит. Вместе с тем проведенные работы позволили уточнить размеры и пространственное положение крупных межблоковых зон в земной коре до глубины 30 км, а также выявить их зонно-блоковое строение. В отдельных случаях можно отметить частичное совпадение фрагментов региональных межблоковых структур с положением древних послойных срывов, однако сеть палеосубдукционных зон и поло- гих сутурных границ, выделенных предшественниками в земной коре Забайкалья [Zorin et al., 1994, 2002], в представленных выше данных MT3 по большому счету не отражается. Активная на новейшем этапе тектогенеза система крупных межблоковых структур в верхней части коры отличается генерализованным субвертикальным и субгоризонтальным положением отдельных зон, которые имеют существенные поперечные размеры. Вероятной причиной отмеченных несоответствий (кроме расположения трансектов в 130 км друг от друга в районе оз. Байкал) является то, что разные методы и способы интерпретации разнотипных геофизических материалов подчеркивают особенности строения коры, сформировавшиеся в эпохи тектогенеза, отличающиеся по времени проявления и типу внешнего воздействия.

Таким образом, тектонофизическая интерпретация геолого-геофизических данных, полученных по всей трассе Шертой - Красный Чикой, позволяет сделать серию выводов об особенностях строения межблоковых структур глобального уровня, используя для этого в качестве примеров Монголо-Охотскую и, особенно, Байкальскую зоны (последняя была пересечена трансектом полностью).

1. Байкальская и Монголо-Охотская межблоковые зоны глобального иерархического уровня являются юго-восточными границами, соответственно, Сибирской плиты и Забайкальского блока. Они протягиваются в северо-восточном направлении на тысячи километров, характеризуются поперечными размерами в первые сотни километров и нарушают литосферу юга Восточной Сибири на всю мощность. На трансрегиональном уровне иерархии глобальные зоны состоят из разломных систем, в развитии которых доминирует единая динамическая обстановка, тип которой (растяжение - для Байкальской и сдвиг - для Монголо-Охотской зон) определяется характером относительных перемещений блоков, а условия реализации - влиянием мантийных флюидов.

2. Высокая флюидизация и проницаемость разломных систем выделяют глобальную зону (межплитную границу) практически в любом геолого-геофизическом поле по известным признакам: характерный набор вещественных комплексов, а также высокие сейсмичность, тепловой поток, дегазация, электропроводность и др. Вместе с тем существует сложность в определении границ зоны и особенностей ее строения, которая обусловлена неравномерным распределением поискового признака в пространстве, что связано с наличием крупных слабонарушенных блоков, характеризующихся аномальными, но обычно прямо противоположными значениями геолого-геофизических показателей. Эти особенности свойственны Байкальской межблоковой зоне, для которой некоторые существенные детали проявления в земной коре юга Восточной Сибири удалось установить в ходе комплексных исследований по трансекту Шертой - Красный Чикой. 
3. Байкальская межблоковая зона глобального уровня отделяет Сибирскую плиту от Забайкальского блока и имеет вдоль трансекта ширину 200 км. Она характеризуется зонно-блоковым строением, главными элементами которого являются Обручевская, Черско-Баргузинская и Джида-Витимская системы растяжения земной коры, каждая из которых состоит из 2-3 разломных зон регионального уровня. Между системами располагаются два крупных блока, один из которых (Хамардабанский) характеризуется высоким гипсометрическим положением и массивным строением, тогда как второй (Байкальский) представляет прямую противоположность, так как вмещает котловину оз. Байкал и в центральной части нарушен широкой слабонаклоненной к юго-востоку зоной повышенной проницаемости и флюидонасыщенности. Зоны регионального уровня, составляющие каждую из разломных систем, являются сбросовыми и наклонены под разными углами в одну сторону, обеспечивая в целом растяжение земной коры региона в направлении С3ЮВ. В Обручевской и Черско-Баргузинской системах растяжения, представляющих борта Байкальской впадины, региональные сбросы «падают», соответственно, на юго-восток и северо-запад, причем разломы, ближние к оси рифта, имеют субвертикальное положение, а периферийные характеризуются явно выраженным наклоном, значение которого особенно заметно увеличивается на глубинах более 20 км. Подобная форма характерна и для Джида-Удинской региональной разломной структуры, входящей в состав Джида-Витимской системы, подвижки в пределах которой, хотя и в меньшей степени, но способствуют реализации растяжения в Байкальской межблоковой зоне.

\section{5. ИЕРАРХИЯ МЕЖБЛОКОВЫХ ЗОН ЮГА ВОСТОЧНОЙ СИБИРИ В СООТВЕТСТВИИ С РЕЗУЛЬТАТАМИ КОМПЛЕКСНОЙ ИНТЕРПРЕТАЦИИ ГЕОЛОГО- ГЕОФИЗИЧЕСКИХ ДАННЫХ ПО ТРАНСЕКТУ ШЕРТОЙ - КРАСНЫЙ ЧИКОЙ}

Результаты комплексного исследования земной коры вдоль трансекта Шертой - Красный Чикой касаются двух главных аспектов. Во-первых, это особенности проявления межблоковых зон в разнотипных, прежде всего геофизических, полях с выходом на эффективный комплекс методов их выделения в глубине коры и на поверхности, когда по разным причинам в исследуемом регионе не могут быть реализованы прямые геолого-структурные наблюдения. Во-вторых, это установление на основе тектонофизической интерпретации геолого-геофизических материалов по трансекту закономерностей организации зонно-блоковой структуры земной коры юга Восточной Сибири с акцентом на строении межблоковых зон разных уровней иерархии. В соответствии с отмеченными аспектами ниже приводится обсуждение материалов, полученных в ходе комплексных исследований.

\section{1. ХАРАКТЕР ПРОЯВЛЕНИЯ МЕЖБЛОКОВЫХ ЗОН ЮГА \\ ВОСТОЧНОЙ СИБИРИ В ГЕОФИЗИЧЕСКИХ, ГИДРОГЕОЛОГИЧЕСКИХ И МОРФОТЕКТОНИЧЕСКИХ ПРИЗНАКАХ}

Порядок рассмотрения особенностей отражения межблоковых зон изучаемого региона в разнотипных полях продиктован возможностью методов выявлять наиболее активные тектонические структуры.

Эманационное поле при прочих равных условиях отражает современное состояние разрывной сети. Судя по нашим наблюдениям и литературным данным [Albul et al, 1979; Sultankhodzhaev et al., 1979; Seminsky, Bobrov, 2012], его аномалии, обусловленные наличием межблоковых зон, определяются двумя тесно связанными факторами. Первым из них является существование в близповерхностной части коры сети проницаемых (открытых) разрывов, а вторым - активных смещений, повышающих за счет дробления эманирующую способность субстрата. Полученные для трансекта Шертой - Красный Чикой результаты (см. рис. 3-6, 11, 14-15) свидетельствуют о принципиальном подобии, но отличиях в деталях распределений почвенных радона и торона в разноранговых межблоковых зонах. Таким образом, на данном этапе при выборе оптимального комплекса исследований зонноблоковой структуры земной коры можно ограничиться анализом поля радона, так как в силу большего по сравнению с тороном периода полураспада он в плане глубинности обладает большей «разрешающей способностью».

Аномальными для выделения межблоковых зон являются высокие значения концентраций почвенного радона, что обусловлено самим характером факторов эманирования, таких как проницаемость и раздробленность. Однако полученные для трансекта данные свидетельствуют о крайне неравномерном распределении параметра $Q$. Это определяется, с одной стороны, высокой мобильностью газов, а с другой - характером проявления межблоковой зоны, т.е. 1) неоднородностью строения и неравномерностью тектонической активности, а также 2) наличием пород (заполнитель), слабопроницаемых для газов (рыхлые глинистые тектониты, продукты выветривания, тонкодисперсные осадки). Как следствие, по форме поперечного профиля можно выделить четыре главных типа радоновых аномалий, связанных с межблоковыми зонами. Их разновидности, согласно двум отмеченным выше факторам, определяются наличием/отсутствием заполнителя в межблоковых зонах сосредоточенного/рассредоточенного типа, которые отличаются, соответственно, наличием или отсутствием главного сместителя. На рис. 17 типы аномалий проиллюстрированы на приме- 


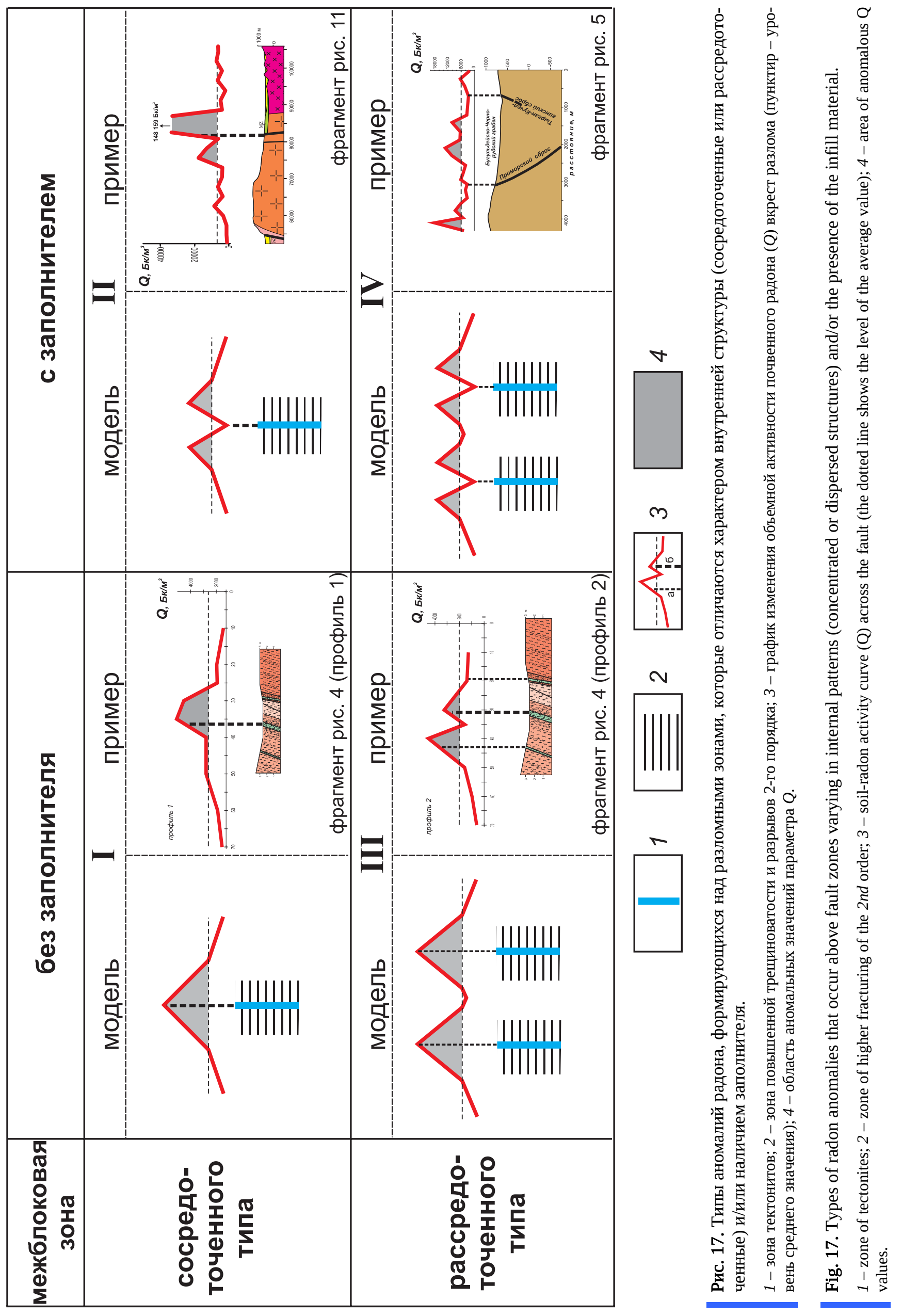



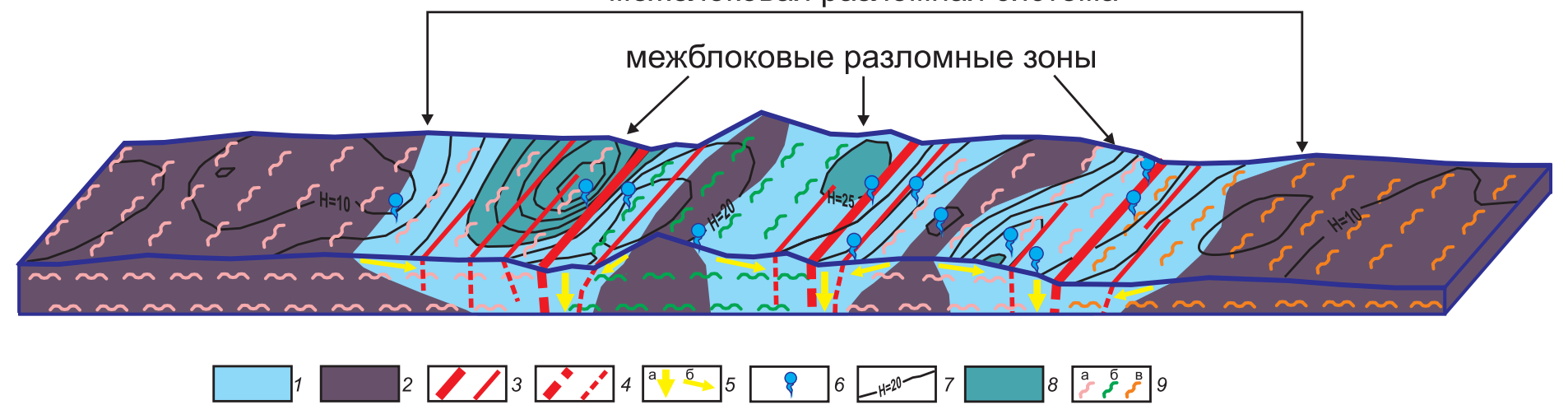

Рис. 18. Принципиальная модель приповерхностной части подземной гидросферы в Прибайкалье, основным структурным элементом которой является межблоковая разломная система.

1 - флюидопроницаемые межблоковые зоны; 2 - слабопроницаемые блоки; 3-4 - крупные и мелкие разломы в разрезе (3) и на земной поверхности (4); 5 - направление миграции метеорных вод: а - субвертикальный нисходящий поток по зонам крупных разломов, б субгоризонтальный близповерхностный поток от области питания к местам разгрузки; 6 - естественный выход подземных вод на поверхность; 7 - распределение параметра $H$ (содержание в пробе воды суммы ионов сульфата и хлора, \%) в изолиниях; 8 - участки затрудненного водообмена (максимумы параметра $H$ ); 9 - разнотипные приповерхностные воды: а - кальций-магниевые, б - преимущественно натриево-калиевые, в - магниево-кальциевые.

Fig. 18. The principal model of the near-surface part of the subsurface hydrosphere in the Pribaikalie. Its main structural element is the interblock fault system.

1 - fluid-permeable interblock zones; 2 - block of low permeability; 3-4 - faults in the cross-section (3) and on the ground surface (4); 5 directions of meteoric water migration: a - subvertical downward flow in zones of large faults, $\sigma$ - subhorizontal subsurface flow from feed areas to offloading areas; 6 - natural outlet of underground water; 7 - distribution of parameter $\mathrm{H}$ (sulphate and chlorine ions contained in water samples, \%) in isolines; 8 - areas of hindered water exchange (maximum values of parameter $\mathrm{H}$ ); 9 - near-surface water of different types: a - calcium-magnesium, 6 - mainly sodium-potassium, в - magnesium-calcium.

рах межблоковых зон разных иерархических уровней, изученных в пределах трансекта и представленных на иллюстрациях к данной статье. В простом случае с проницаемой зоной сосредоточенного типа (I) имеет место постепенное повышение объемной активности радона от периферии к главной поверхности смещения. В самом сложном случае (IV), т.е. при наличии тонкодисперсного заполнителя (глинка трения, выветрелые породы, глинистые осадки) и/или системы второстепенных разрывов и блоков с разной проницаемостью, аномалия представлена чередованием участков высоких и низких значений объемной активности радона. Два промежуточных случая (II-III) дают аналогичную («двугорбую» в разрезе) аномалию с периферийными максимумами и осевым минимумом. Однако в одном случае (II) минимум располагается над главным разломом с глинкой трения, а в другом (III) - над блоком между двумя проницаемыми второстепенными разломами.

Таким образом, достоинством радоновой съемки при исследовании межблоковых зон земной коры является возможность выделения структуры, активной на современном этапе тектогенеза. Недостатки связаны с мобильностью газов, которые чутко реагируют на изменения напряженно-деформированного состояния приповерхностной части коры под действием перечис- ленных выше факторов. Как следствие, неоднозначность интерпретации данных радоновой съемки возрастает в геодинамически активных регионах, где для выделения границ и особенностей строения межблоковых зон необходимо сочетать данный вид исследований с другими методами полевой геофизики.

Гидрогеологические особенности межблоковых зон определяются особенностями рельефа, вещественным составом, а также проницаемостью их субстрата, которая прямо связана с состоянием разрывных сетей в верхней части земной коры. Исследования, представленные в данной статье и более подробно - в нашей предыдущей публикации [Seminsky, Tugarina, 2011], позволили отразить роль перечисленных факторов в формировании свойств подземных вод изучаемого региона в виде обобщающей модели (рис. 18). В качестве основы для ее построения использовались результаты анализа минерализации, анионного и катионного состава подземных вод, а также распределения их естественных источников в пределах северо-западного сегмента трансекта. Согласно модели, зонно-блоковая структура через специфику рельефа и нарушенности массива горных пород определяет гидрогеологические особенности верхней части земной коры в геодинамически активном регионе. Межблоковые зоны как наиболее нарушенные и пониженные в рельефе участки 
коры являются аномалиями по общей обводненности и режиму водообмена, что выделяет их в сравнении с блоками с бо́льшим количеством естественных выходов подземных вод трещинно-жильного типа с высоким процентным содержанием суммы сульфат- и хлорионов (см. рис. 6, B), а зачастую и повышенной минерализацией.

Специфика вещественного состава горного массива, определяющая его способность к растворению, служит звеном, осложняющим проявление ведущей роли структуры земной коры в формировании основных свойств подземных вод в геодинамически активном регионе. Пространства отдельных блоков, которые при тектоническом контактировании обычно отличаются по петрографическому составу, характеризуются катионными соотношениями, отличающимися от таковых для аналогичных смежных элементов структуры (рис. 18). Эта закономерность широко известна для регионов с отчетливо выраженной разломно-блоковой структурой [Bastrakova, 1985; 1990; Stepanov, 1989; Khaustov, Grabar, 1999; Sorokina et al., 2011; and others], где, согласно нашим представлениям, межблоковые зоны относятся к структурам поздней дизъюнктивной стадии развития с явно выраженным главным сместителем, который слабопроницаем для подземных вод. Результаты исследования фильтрационных свойств субстрата разломов Приольхонья методом наливов (см. рис. 4, Г) свидетельствуют о том, что в Прибайкалье межблоковые зоны локального уровня вследствие наличия продуктов выветривания характеризуются низкой проницаемостью по сравнению со смежными участками крыльев. Учитывая широкую распространенность в регионе линейной латерит-каолиновой коры выветривания, следует предполагать, что большинство разноранговых межблоковых зон Прибайкалья должны выполнять роль водоупоров. Таким образом, подземные воды, мигрируя со стороны приподнятых блоков к впадинам, выходят на поверхность у крупного сместителя или/и сбрасываются на более глубокие уровни коры (на десятки километров, согласно [Pinneker et al., 1998]) по смежному с водоупором проницаемому участку межблоковой зоны с густой сетью разрывов оперения и открытой трещиноватости (рис. 18).

Достоинством гидрогеологических методов исследования межблоковых зон является возможность прямого наблюдения за агентом - подземными водами, который в большей или меньшей степени определяет характер многих связанных с ними геофизических полей. Среди недостатков выделяется неоднозначный практически для каждого гидрогеологического показателя характер аномалий, обусловленный различием проницаемости отдельных структурных элементов межблоковой зоны, а также осложняющим влиянием вещественного фактора. Это в совокупности с обычным для природных условий недостатком проявлений естественных выходов подземных вод позволяет счи- тать гидрогеологические методы хотя и значимым, но второстепенным элементом комплекса по исследованию межблоковых зон земной коры.

Электромагнитное поле, отдельные характеристики которого были получены в ходе работ по трансекту посредством реализации методов МТЗ, электропрофилирования и ЕП, в значительной степени для изученного региона обусловливается распределением, составом и миграцией подземных вод и других флюидов в земной коре.

Геоэлектрические разрезы, построенные по результатам магнитотеллурических зондирований (см. рис. 6, $\Gamma ; 8, Б ; 11, \Gamma ; 14, \Gamma ; 15, Ж ; 16, B-\Gamma)$, позволяют выделять в земной коре юга Восточной Сибири крупные межблоковые зоны в виде участков аномально низкого УЭС (0.5-100 Ом·м). Аномалии характеризуются неравномерным распределением проводимости, которая для межблоковых зон обусловлена их внутренним зонно-блоковым строением. Как видно на примере Обручевской разломной системы (см. рис. 6, Г), проводящие участки представляют межблоковые зоны регионального уровня, распространяющиеся до низов коры. Эти участки пространственно совпадают с близповерхностными аномалиями водообмена, но, судя по отличию размеров (см. рис. 6, B), - по-разному. Для Морской зоны, несмотря на дефицит гидрогеологических данных, можно говорить об удовлетворительном соответствии. Поперечные размеры разнотипных аномалий, приуроченных к Прихребтовой зоне, примерно одинаковы за исключением верхней части геоэлектрического разреза (до глубины 3 км), где ширина зоны пониженных сопротивлений уменьшается почти вполовину. Наибольшие отличия характерны для Приморской межблоковой зоны, которая не проявлена непрерывным в разрезе участком низких УЭС. Упомянутые несоответствия объясняются близповерхностным характером изученных подземных вод и не противоречат принципиальному выводу о том, что глубинные аномалии проводимости в самой верхней части коры представлены нарушенными обводненными зонами. Этот результат в совокупности с такими признаками аномалий проводимости, как значительные поперечные размеры и плавные границы, слабые анизотропия и градиенты поля УЭС, подтверждает на более представительном фактическом материале вывод предшественников [Popov, 1987; Berdichevsky et al., 1999; Kissin, Ruzaikin, 2000] о флюидной природе зон и слоев в земной коре изучаемого региона. Флюиды, привнесенные или образовавшиеся при метаморфической дегидратации, заполняют пустоты, трещины и более крупные разрывы в зоне блоковых взаимодействий, причем их сеть, судя по минимальным УЭС, характеризуется наибольшей густотой в осевых частях межблоковых структур.

Предполагаемая природа геоэлектрических аномалий подтверждается при сопоставлении геодинамической и флюидной активности межблоковых зон изу- 
ченного региона. В Байкальском рифте, где позднекайнозойская тектоническая активность проявлена наиболее интенсивно, выходы термальных вод приурочены к тем региональным межблоковым зонам, у которых глубинные аномалии проводимости наиболее близко подходят к поверхности (см. рис. $16, B-\Gamma$ ). Это Обручевская система на западном плече рифта, где вдоль северо-восточных разломов зафиксированы выходы травертин и гейзеритов позднего неоплейстоцена [Sklyarov et al., 2007], а также Черско-Баргузинская разломная система с современными источниками термальных вод на его восточном плече (районы пос. Энхалук, Горячинск и др.). Кроме того, основной канал для миграции глубинных флюидов располагается вблизи осевой части рифта, где по данным МТЗ выделена аномалия проводимости, имеющая сквозькоровый характер, высокую интенсивность и наибольшие поперечные размеры. С функционированием этого канала могут быть связаны выходы газов (и, возможно, термальных вод) на дне озера Байкал, для которых проводящими структурами являются зоны повышенной трещиноватости в рыхлых осадках (см. рис. 10). С другой стороны, тесная связь степени геодинамической активности и флюидизации коры косвенно подтверждается тем, что Предбайкальская субвертикальная межблоковая зона, фиксирующаяся для слабоактивизированного в позднем кайнозое южного края Сибирского блока, не отмечается предельно низкими УЭС. То же относится к фиксирующемуся здесь и в Забайкальском блоке субгоризонтальному проводящему слою, флюидная природа которого в связи с предполагаемым питанием поверхностными [Pinneker et al., 1998] или глубинными [Pospeev, 1998] потоками отмечалась в процитированных работах.

Согласно вышеизложенному, главные особенности поля удельного электрического сопротивления, полученные для Прибайкалья в результате интерпретации материалов МТ3, могут быть представлены в виде обобщенного разреза участка земной коры, нарушенного разломной системой (рис. 19). Он относительно прост по сравнению с аналогичными структурами из других активных регионов мира [Hoffmann-Rothe et al., 2004; Bataleva, 2005; Chen et al., 2007; Xiao et al., 2011], но однозначно подтверждает справедливость тех представлений, которые, хотя и были предложены на основе анализа разнотипных (геофизических [Kissin, 1996; Gutmanis et al., 1998; Berdichevsky et al., 1999; Neubauer et al., 2005; Becken et al., 2008; and others] или гидрогеологических [Stepanov, 1989; Khaustov, Grabar, 1999; Bastrakova, 1985, 1990; and others]) данных, но исходили из единой разломно-блоковой модели земной коры. Поле УЭС определяется характером (растяжение для Прибайкалья) и степенью (высокая) тектонической активности региона, которая в совокупности с изначальной структурно-вещественной спецификой субстрата формирует неоднородный по нарушенности объем земной коры, в существенной степени заполненный флюидами. Как следствие, геодинамически активная разломная система является, по существу, системой флюидной с нисходящей и восходящей миграцией близповерхностных вод и глубинных растворов, которая в поле УЭС отражается сетью зон с аномально низкими сопротивлениями (<100 Ом·м). Доминируют субвертикальные зоны, в центральных частях которых УЭС может опускаться до 0.5-5.0 Ом·м, однако присутствуют и субгоризонтальные проводящие слои, которые в структурном плане представляют необходимый элемент для автономного перемещения блоков в ходе тектогенеза. Ширина зон и слоев является значимой в связи с глубоким проникновением флюидов в блоки, у которых лишь центральные, сравнительно слабодислоцированные части характеризуются низкой проводимостью (УЭС=100010000 Ом·м). Особенно отчетливо это проявляется у свободной поверхности в связи с разгрузкой напряжений, способствующей «разрыхлению» массива, что приводит к расширению межблоковых зон, размеры которых в геодинамически активных регионах соизмеримы с пространствами блоков или превышают их.

Таким образом, магнитотеллурические зондирования представляет эффективный инструмент выявления в глубоких горизонтах коры межблоковых зон, которые развиваются в режимах растяжения и сдвига, способствующих проникновению флюидов в проницаемые участки. Несмотря на сложности проведения детальных съемок и неоднозначность интерпретации некоторых структурных ситуаций, МТЗ образуют необходимую часть методического комплекса для изучения зонно-блоковой делимости земных недр в тектонически активных регионах.

Электропрофилирование, реализованное на трансекте для всех масштабов исследования, позволило оценить геоэлектрические свойства самой верхней части коры, нарушенной разноранговыми межблоковыми зонами. Интерпретация многочисленных графиков вариаций кажущегося удельного электрического сопротивления вкрест простирания изучаемых структур (см. рис. $4, \Gamma$; 5, $E$; $6, B ; 11, B$ ) подтвердила результаты предшественников, согласно которым они трассируются участками пониженных величин $\rho_{\kappa}$. Факторами, обеспечивающими низкие величины кажущего электрического сопротивления и значимых для изученного региона, являются обводненность и нарушенность субстрата в межблоковой зоне. Следует отметить, что первый фактор играет ведущую роль в формировании специфики геоэлектрического разреза межблоковой зоны на глубинах, больших по сравнению с теми, которые изучаются методами электропрофилирования. Об этом свидетельствуют, с одной стороны, данные МТЗ, а с другой - выделение разломных зон низкими значениями коэффициента фильтрации воды, установленными путем проведения натурных экспериментов в Приольхонье на примере структур локального уровня (см. рис. 4, Г-2). Как следствие, до 


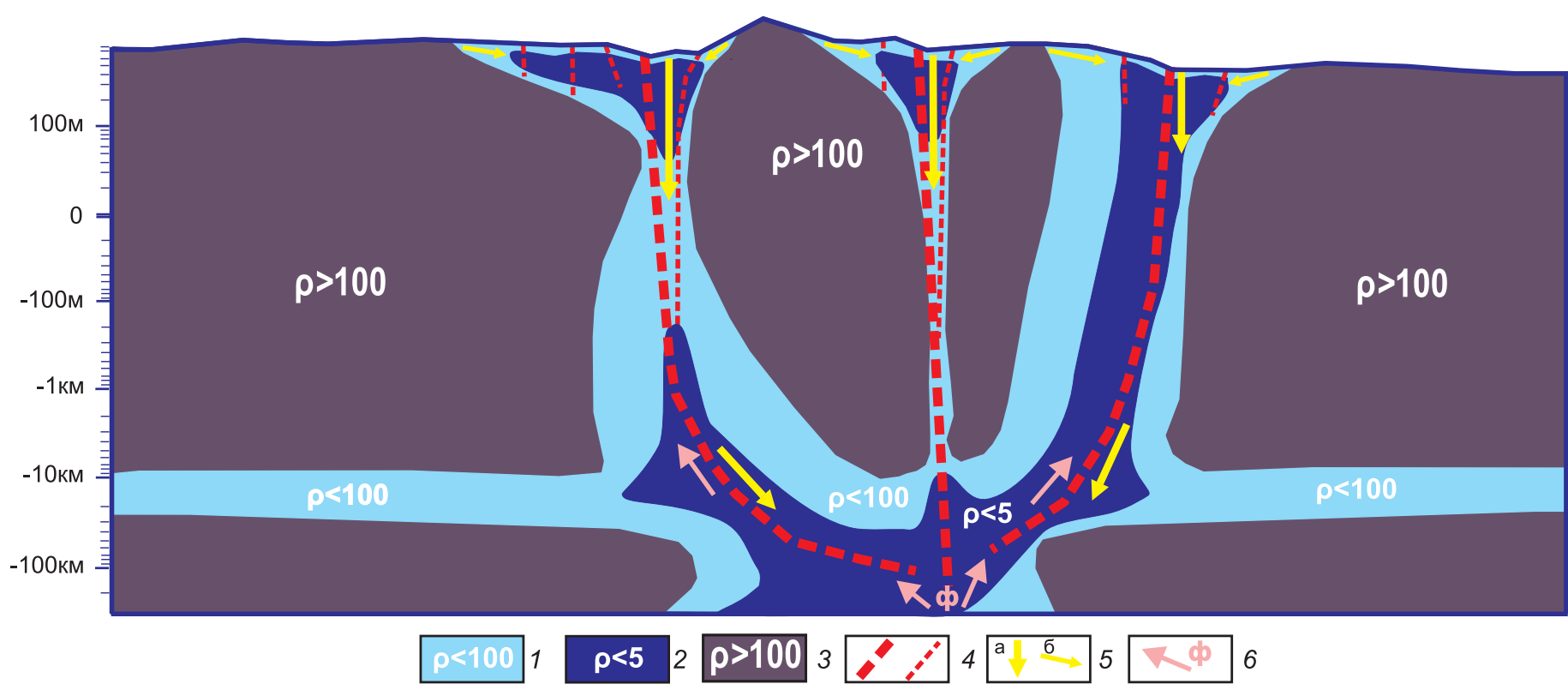

Рис. 19. Обобщенный геоэлектрический разрез типичного для Прибайкалья участка земной коры, главным структурным элементом которого является межблоковая разломная система.

1 - флюидопроницаемые межблоковые зоны с низким удельным электрическим сопротивлением ( $\rho<100$ Ом·м); 2 - наиболее нарушенные и флюидонасыщенные участки межблоковой зоны с $\rho$, меньшим 5 Ом·м; 3 - слабопроницаемые блоки с высоким $\rho$; 4 - крупные и мелкие разломы; 5 - направление миграции метеорных вод: а - субвертикальный нисходящий поток по зонам крупных разломов, б субгоризонтальный близповерхностный поток от области питания к местам разгрузки; 6 - восходящий флюидный поток по проницаемым зонам.

Fig. 19. The generalized resistivity profile of a segment of the crust which is typical of the Pribaikalie. Its main structural element is the interblock fault system.

1 - fluid-permeable interblock zones with low resistivity $(\rho<100 \mathrm{ohm} \cdot \mathrm{m}) ; 2$ - the most disturbed areas and fluid-saturated segments of the interblock zone where $\rho$ is below $5 \mathrm{ohm} \cdot \mathrm{m}$; 3 - poorly permeable zone with high $\rho ; 4$ - faults; 5 - directions of meteoric water migration: a subvertical downward flow in zones of large faults, 6 - subhorizontal subsurface flow from feed areas to offloading areas; 6 - ascending flow of fluids in permeable zones.

глубин в первые десятки метров поле $\rho_{\kappa}$ определяется степенью нарушенности субстрата межблоковых зон, причем в Прибайкалье ведущую роль в его формировании играет не столько плотность разрывных нарушений, сколько степень выветривания, продукты которого для магматических и метаморфических пород характеризуются низкими сопротивлениями (2-1200 Ом·м, согласно [Palacky, 1989]). Для Прибайкалья это связано преимущественно с тем, что вызванная рифтингом активизация перемещений произошла в зонах древних разломов, субстрат которых подвергнут глубокому выветриванию в эпоху мел-палеогеновоой планации рельефа [Logachev et al., 1964; Logachev, 2003].

Принципиальные особенности аномалии $\rho_{\kappa}$, связанной с типичной для Прибайкалья межблоковой зоной разломного типа, отражены на рис. 20. Геолого-геофизическую основу для формирования обобщенных представлений составили данные изучения региональной разломной зоны Приморского сброса (см. рис. 5). Показано, что в условиях Прибайкалья межблоковые зоны вследствие структурной неоднородности внут- реннего строения выделяются сложнопостроенными аномалиями, для которых характерно наличие нескольких диапазонов кажущегося электрического сопротивления. Абсолютные значения уровней, маркирующих эти диапазоны, отличаются для разных участков исследования в связи с отличиями проводящих свойств горных пород, нарушенных конкретной межблоковой зоной. Однако в качественном отношении для многих детально изученных разломных зон отчетливо выделяются три характерных значения $\rho_{\kappa}$. Первый уровень отделяет приразломную аномалию от высокоомных крыльев, причем во внутренней структуре самой зоны он соответствует трещиноватым блокам. Последние представлены сравнительно небольшими участками, тогда как основное пространство занимают выветрелые зоны с высокой плотностью разноранговых поверхностей смещения (сколовых трещин и разломов), где сопротивление уменьшается в два раза. Наконец, внутри этих зон могут иметь место участки аномально низких значений $\rho_{\kappa}(2-5$ Ом·м), обусловленных высокой степенью выветривания (рис. 20, B) или/и наличием крупных сместителей, представлен- 

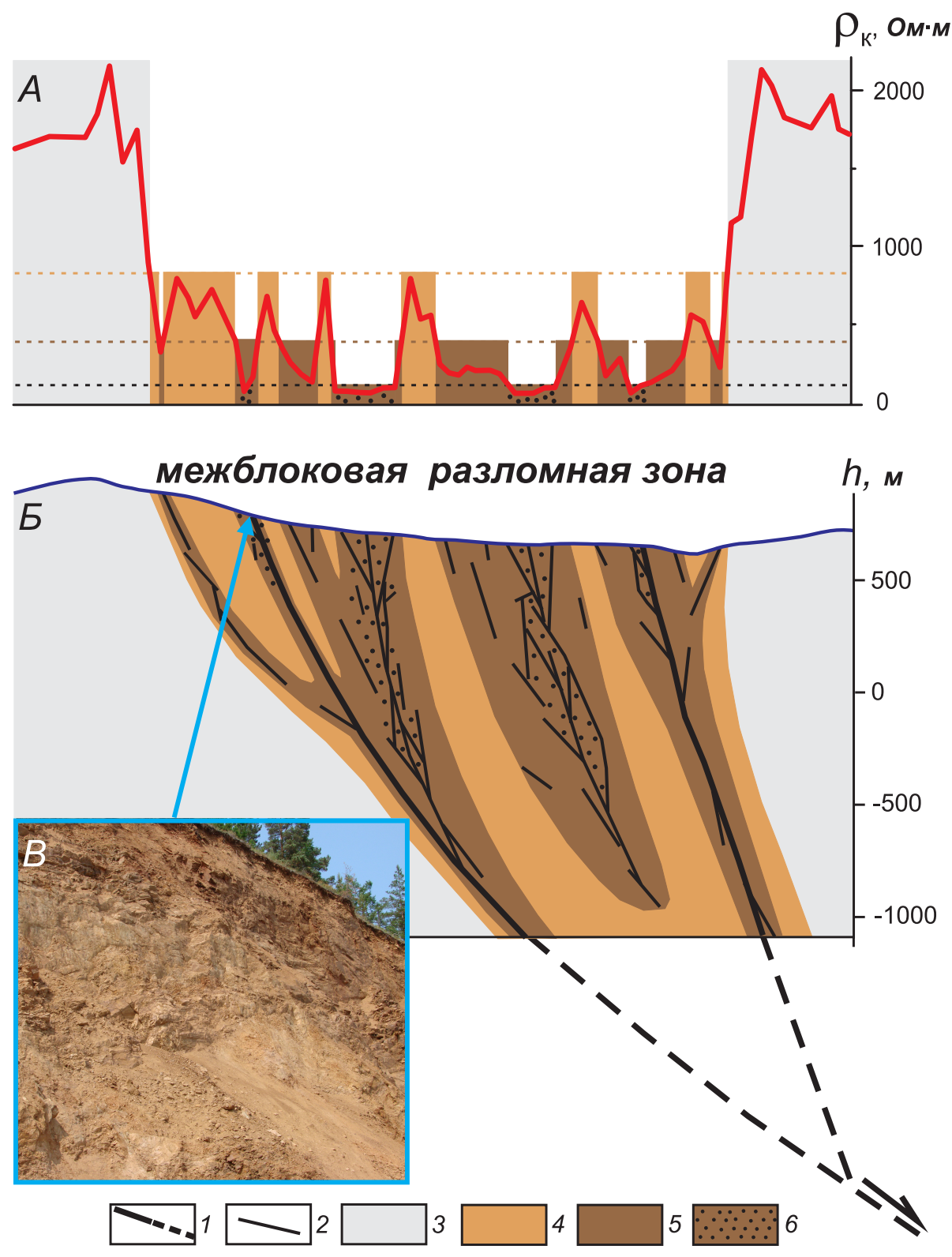

Рис. 20. Характерные особенности аномалии $\rho_{\kappa}$, связанные с межблоковыми зонами разломного типа в геодинамически активных районах Прибайкалья.

$A$ - график приразломных вариаций $\rho_{\kappa}$, на котором разными оттенками коричневого цвета и точечным крапом показаны различные уровни аномальных значений параметра; $Б$ - принципиальный структурный разрез межблоковой зоны сбросового типа, на котором разными оттенками коричневого цвета и точечным крапом показаны участки, отличающиеся степенью нарушенности вследствие различий в интенсивности действия процессов выветривания и разрывообразования; $B$ - фотография коренного выхода с высокой степенью нарушенности, обусловленной интенсивным выветриванием зоны магистрального разломного сместителя. 1 - крупные разломные сместители; 2 - более мелкие разрывные нарушения; 3 - высокоомные участки за границами разломной зоны; 4 - области на графике и блоки внутри разломной зоны на разрезе, которым соответствует аномальная, но сравнительно низкая степень нарушенности пород; 5 - области на графике и разломные зоны 2-го порядка на разрезе, которым соответствует высокая степень нарушенности горных пород; 6 - области на графике и приосевые части разломных зон 2-го порядка, которые отличаются наибольшей степенью нарушенности пород (с глинкой трения).

Fig. 20. Specific features of the anomaly $\rho_{\mathrm{k}}$ which are associated with interblock fault zones of various types in geodynamically active regions of the Pribaikalie.

$A$ - the curve showing near-fault variations of $\rho_{\mathrm{k}}$ values. Different levels of anomalous values of the parameter are shown by different shades of brown and dotted patterns; $\overline{-}$ - the principal structural cross-section of the interblock zone of normal-fault type. Different shades of brown and dotted patterns are used to show segments that differ in the degree of disturbance due to differences in the intensity of weathering and faulting; $B$ the photo shows an outcrop with a high degree of disturbance caused by intense weathering of the zone of the major fault plane. 1 - large faults; 2 - fractures; 3 - areas with high ohm values outside the fault zone; 4 - areas at the curve and blocks within the fault zone in the cross-section, which rock disturbance is anomalous yet relatively low; 5 - areas at the curve and fault zones of the 2nd order in the cross-section, which rock disturbance is high; 6 - areas at the curve and near-axial segments of the fault zones of the 2 nd order, which rock disturbance is the highest (with gouge). 
ных глинкой трения (рис. 20, Б). Следовательно, в материалах электропрофилирования по различию уровней нарушенности может определяться внутренняя зонно-блоковая структура межблоковых зон.

Таким образом, достоинством электропрофилирования, кроме экспрессности и невысокой стоимости работ, является возможность выделения нарушенных и обводненных участков в самой верхней части коры. Вместе с тем сложность строения межблоковых зон многократной активизации приводит к формированию аномалий $\rho_{k}$, достоверная интерпретация которых возможна только после приобретения достаточного опыта работ в изучаемом регионе, причем дополнительная сложность возникает при вычленении в выветрелом массиве участка проявления интенсивных позднекайнозойских перемещений. Таким образом, изучение поля кажущегося удельного электрического сопротивления вблизи земной поверхности должно быть неотъемлемой составляющей исследований разломных межблоковых зон земной коры и осуществляться в комплексе с другими геофизическими методами. При этом в настоящее время целесообразно вместо СЭП использовать более современный метод электротомографии [Dahlin, 2001], позволяющий без потерь в экспрессности и достоверности оценок получать двумерные и трехмерные (при площадной съемке) распределения параметра $\rho_{\kappa}$ в массиве горных пород.

Метод ЕП эффективен при изучении зонно-блоковой структуры земной коры, поскольку составляющие ее элементы в изученном регионе отражаются характерными минимумами потенциала естественного электрического поля. Во-первых, это активизированные при рифтогенезе межблоковые зоны, которые, например, в Западном Прибайкалье (см. рис. $5, B ; 6, B$ ), представлены древними тектонитами с повышенным содержанием графита [Kozhevnikov, 1998; Kozhevnikov et al., 2004]. Во-вторых, это блоки, которые при высоком положении в современном рельефе (например, хр. Хамар-Дабан) являются причиной активной нисходящей миграции метеорных вод, создающей естественное электрическое поле с низким потенциалом ЕП (см. рис. $11, B$ ). Таким образом, реализация метода ЕП дает важные сведения о вещественной составляющей межблоковых зон, а также позволяет определять положение их границ при переходе к смежным относительно высокоподнятым блокам. Однако при изучении межблоковых зон эта информация носит второстепенный характер, что позволяет рекомендовать применение ЕП в качестве вспомогательного метода, целесообразного при исследовании происхождения связанных с разломами геоэлектрических аномалий.

Магнитное поле при исследованиях по трансекту для отдельных межблоковых зон обнаружило подобие с полями кажущегося удельного сопротивления и потенциала ЕП. В большинстве случаев межблоковые зоны в магнитном поле выделяются минимумами, что согласуется с данными предшественников [Glinsky et al., 1991; Morozova et al., 1998]. Характер и причины установленных особенностей требуют постановки специальных исследований, так как они прямо не связаны с распространением в пределах разломных зон магнитных геологических образований (исключая обогащение при разрушении). Это в настоящее время не позволяет рекомендовать магниторазведку для включения в комплекс работ по изучению внутреннего строения межблоковых зон земной коры Прибайкалья.

Морфотектонические особенности проявления межблоковых зон имеют в условиях юга Восточной Сибири исключительную важность для выделения их границ и деталей внутреннего строения. Это связано, прежде всего, с тем, что межблоковые структуры рассматриваемой территории на всех уровнях иерархии, как правило, отчетливо проявляются пониженными формами рельефа по отношению к более высокостоящим блокам (см. рис. 4, $A-3 ; 4,5 ; 5, A ; 6,5 ; 9,5 ; 11,5$; 14,$5 ; 15$, Д). Данная закономерность обусловлена режимом растяжения земной коры, господствующим в последнюю эпоху тектогенеза на большей части изученной территории, а также интенсивной эрозией нарушенного субстрата зон по сравнению с относительно массивными блоками. Следует отметить, что полученные материалы на новом уровне исследований лишь подтверждают закономерность, по большому счету известную для рассматриваемого региона после трудов Н.А. Флоренсова и его последователей. Н.А. Флоренсовым [Florensov, 1960], в частности, для отдельных детально изученных регионов (например, Приольхонья) показана ведущая роль нарушенных за счет тектонических процессов и выветривания разрывных зон в формировании рельефа и береговой линии оз. Байкал, а также обосновано разломное происхождение крупных впадин Прибайкалья и Забайкалья.

Работы по трансекту в прямом и переносном смысле углубили эти представления, показав, с одной стороны, специфику проявления в рельефе деталей внутреннего строения разноранговых межблоковых зон, а с другой - факт парагенетической взаимосвязи крупных впадин Прибайкалья и Забайкалья, пересеченных трансектом Шертой - Красный Чикой, с аномалиями проводимости, трассирующимися на геоэлектрическом разрезе до глубин в первые десятки километров (см. рис. 16). Это позволяет с большой долей уверенности использовать рельеф юга Восточной Сибири для предварительного прогноза особенностей глубинного строения земной коры. Кроме того, спрямленные элементы земной поверхности, отчетливо фиксирующиеся на топографических картах и трехмерных моделях, в большинстве случаев для рассматриваемой территории отражают положение разломов, активных в позднем кайнозое. Как следствие, максимумы их плотности соответствуют зонам, а минимумы - слабонарушенным блокам земной коры (см. рис. $6, B ; 11, B ; 14, B$ ). Именно поэтому положение межблоковых зон, границы которых на предварительно построенной схеме 
зонно-блоковой структуры изучаемого региона (см. рис. 2, Б) были проведены в соответствии с распределением крупных линеаментов рельефа, по большому счету подтвердилось при детальном исследовании, выполненном на основе комплекса полевых геологогеофизических методов по трансекту Шертой - Красный Чикой (см. рис. 6, 11, 14).

Таким образом, анализ рельефа земной поверхности разными морфометрическими способами является неотъемлемой частью комплекса исследований межблоковых зон юга Восточной Сибири. Данное заключение тем более справедливо с учетом прогресса в области современных методов съемки земной поверхности, а также возможности работы со многими материалами подобного типа в открытом доступе и с использованием мощной вычислительной техники. В целом анализ рельефа в том или ином виде должен быть опережающим по отношению к другим методам изучения межблоковых зон земной коры. Он позволяет в первом приближении обозначить их границы и оценить степень нарушенности субстрата, а также в какой-то мере определиться с видами последующих геофизических и гидрогеологических методов, поскольку результаты их применения, как было представлено на обобщающих моделях (см. рис. 18-20), тесно связаны с контрастностью современного рельефа.

Сопоставление результатов применения перечисленных видов исследований для одних и тех же участков земной коры проводилось по материалам, представленным на рис. 3-6, 11, 14-16, и показало, что располагающиеся в их пределах межблоковые зоны выделяются практически в каждом из изученных полей, хотя и с индивидуальными особенностями. В силу отличий оцениваемых показателей их аномалии поразному подчеркивают элементы внутреннего строения одной и той же зоны. Использованные методы можно разделить на две группы по степени направленности на выделение собственно разрывной структуры как ключевой составляющей межблоковых зон. К прямым методам относится анализ рельефа с целью выделения линеаментов-разломов и эманационная съемка, позволяющая выявлять современные зоны распространения открытых нарушений сплошности, а также разрывы с активными перемещениями крыльев. Остальные методы следует считать косвенными, поскольку они направлены на выделение заполнителя межблоковых 3он, в большей или меньшей степени свойственного их представителям. Это жидкий заполнитель для гидрогеологических и электроразведочных методов и твердая составляющая (глинистый, графитовый, сульфидный и другие заполнители) для электро- и магниторазведки.

Первая группа методов в принципе предпочтительнее для исследования разломных зон, однако достоверность интерпретации результатов этих методов зависит от некоторых важных особенностей их применения. Во-первых, необходимо представление о том, в каком объеме выделяется межблоковая структура по анализируемому признаку. Если в качестве примера взять эманационную съемку, то, как было установлено ранее [Seminsky, Bobrov, 2009], поперечный размер приразломной аномалии радона в 1.4 раза превышает аналогичную по типу оценку, полученную по распределению плотности разрывов, т.е. собственно структурному признаку. Это, по-видимому, связано с тем, что выход газов происходит, в том числе, и в периферийной зоне микротрещиноватости, которая обычно не учитывается при подсчете плотности составляющих зону мелких разрывов. Во-вторых, даже для прямых методов выявления разрывов существует неоднозначность интерпретации, так как рассматриваемый признак, кроме выявления разрывов, может давать аномалию от присутствия других, в том числе и неструктурных, элементов. Это очевидно для линеаментного анализа рельефа, а также может быть связано с присутствием радиоактивных пород на участке проведения эманационной съемки.

Кроме рассмотренной выше специфики использованных методов, степень различия в проявлении одной и той же межблоковой зоны в том или ином поле зависит: 1) от индивидуальных особенностей межблоковой структуры и 2) от условий ее существования в земной коре. Первый фактор определяется масштабом, интенсивностью, направленностью и длительностью однотипного воздействия тектонических сил, которые приводят к формированию межблоковых зон, отличающихся, соответственно, масштабным рангом (локальные, региональные и другие зоны), геодинамической активностью (зоны высокой, умеренной или низкой активности), типом (зоны растяжения, сжатия или сдвига) и стадией развития внутренней структуры (для разломных зон - ранняя, поздняя или полного разрушения). Специфика отражения каждого из перечисленных видов межблоковых зон почти для всех обсуждаемых методов требует проведения отдельного целенаправленного исследования. Исключение составляет эманационная радоновая съемка, особенности которой в приложении к разломным зонам юга Восточной Сибири и Монголии были детально изучены до постановки работ на трансекте [Seminsky, Bobrov, 2009]. Так, крупные разломные зоны характеризуются большей радоновой активностью по отношению к мелким, а разломы с высокой геодинамической активностью при прочих равных условиях создают самые интенсивные в сравнении с фоном аномалии. Очевидно, что выход радона происходит более интенсивно в условиях растяжения, чем при сдвиге и, тем более, - сжатии, что в одной из цитированных статей было показано на примере сопоставления разломов сбросового и сдвигового типов. Наконец, коренные отличия в строении аномалий у зон рассредоточенного типа, к которым в первую очередь относятся разломы ранней стадии развития, от проявления в поле радона сосредоточенных структур, например разломов стадии полного разру- 
шения, были описаны в данной статье и представлены в обобщенной форме на рис. 17.

Второй фактор - условия существования межблоковой зоны в земной коре - придает специфические особенности ее проявлению в любом из рассматриваемых полей. В связи с эманационным полем обобщение по данному вопросу представлено в одной из наших работ [Seminsky, Bobrov, 2012] на основе анализа мировых данных и результатов собственных детальных исследований концентраций почвенного радона вблизи разломов Прибайкалья и Забайкалья, многие из которых расположены в пределах трансекта Шертой Красный Чикой. Показано, что в рассматриваемом аспекте наиболее значимыми являются три группы процессов: эрозионные, планетарные и геохимические. Эрозионные процессы и выветривание контролируют распределение и размеры участков разломной зоны, заполненных тонкодисперсным материалом, что корректирует размеры, форму и амплитуду радоновой аномалии. Процессы планетарных взаимодействий (Земли с Луной и Солнцем) обусловливают вариации атмосферного давления, которые приводят к периодическим изменениям проницаемости и, следовательно, концентрации почвенного радона в пределах активных разломных зон земной коры. Геохимические факторы (содержание урана во вмещающих породах или тектонитах) также влияют на формирование аномалий почвенного радона, хотя их роль является значимой только для отдельных участков земной коры.

Материалы разнотипных исследований на трансекте показали, что некоторые из перечисленных для радона процессов также оказывают существенное влияние на формирование вблизи межблоковых зон полей другой природы. Для эрозионных процессов это происходит через формирование рельефа, который, как было показано выше, имеет самостоятельное значение в исследовании межблоковых зон, играет важную роль в миграции и формировании состава подземных вод, создании аномалий потенциала ЕП. Процесс выветривания определяет поле $\rho_{\kappa}$ в близповерхностной части земной коры Прибайкалья, где вдоль разломов развита линейная латерит-каолиновая кора, сформировавшаяся в мел-палеогеновое время. Планетарные воздействия для большинства изученных полей приводят к их временным вариациям, что является темой специальных исследований, которые особенно перспективны в плане оценки степени активности межблоковых зон на современном этапе тектогенеза. Кроме этих процессов, существенную роль в проявлении межблоковых зон на всех уровнях коры играет степень ее флюидизации. Как было показано при характеристике отдельных методов исследования, она определяет гидрогеологические особенности межблоковых зон Прибайкалья, играет важнейшую роль при формировании связанных с ними на всех уровнях коры глубинных аномалий удельного электрического сопротивления и приповерхностных аномалий потенциала ЕП, влияет на рас- пределение газовых потоков, в том числе хорошо растворимого радона. Представляется, что развитие геофизических методов картирования межблоковых зон в значительной степени связано с прогрессом дальнейших целенаправленных исследований по изучению роли флюидов и газовой составляющей в формировании их свойств.

Следствием сложности внутреннего строения межблоковых зон, специфики условий их существования и особенностей использованных методов исследования является определенная неоднозначность в проведении границ этих структурных элементов. Очевидно, что для одной и той же зоны они будут несколько отличаться в зависимости от типа использованных для анализа признаков. Комплексные исследования по трансекту Шертой - Красный Чикой показали, что отправным моментом для установления границы «блок-зона» является примерное совпадение переходов от аномалии к фону, определенное по двум-трем признакам. При этом для всех полей в качестве порога «фонаномалия» может с успехом использоваться значение среднего арифметического без его увеличения или уменьшения (в зависимости от типа анализируемого поля) на величину среднеквадратичного отклонения. Именно такой подход использовался при интерпретации данных по всем сегментам трансекта (см. рис. 6, $11,14)$. Окончательное решение о положении границы каждой межблоковой зоны принималось после анализа конкретной ситуации и оценки возможности отражения ее внутренней структуры в отдельных полях с учетом описанных ранее внешних факторов.

Опыт подобных построений показал, что опорными для определения поперечных размеров межблоковых зон являются оценки, полученные по вариациям плотности линеаментов и высоты рельефа, суммы в подземных водах сульфат- и хлор-ионов, концентрациям в почвенном воздухе радона и торона, а в разрезе - по величинам удельного электрического сопротивления (см. рис. 6, 11, 14). Отличия в размерах межблоковых зон, установленные по распространению аномальных значений перечисленных параметров, не являются принципиальными. Как следствие, именно эти признаки фигурировали в концептуальной модели структуры земной коры, представленной в одной из предыдущих публикаций на базе интерпретации геолого-геофизических материалов по сегменту Баяндай - Крестовский [Seminsky, Tugarina, 2011]. После анализа полного объема материалов по трансекту эта модель изменилась лишь в деталях (рис. 21), что следует из описания, представленного выше для двух главных составляющих блок-диаграммы: модели в плане (см. рис. 18) и модели в разрезе (см. рис. 19). Рис. 21 наглядно иллюстрирует, что межблоковые зоны земной коры юга Восточной Сибири выделяются по сравнению с пространствами блоков понижениями в рельефе, аномалиями условий водообмена, положительными и сложными по форме газовыми аномалиями, а также низки- 


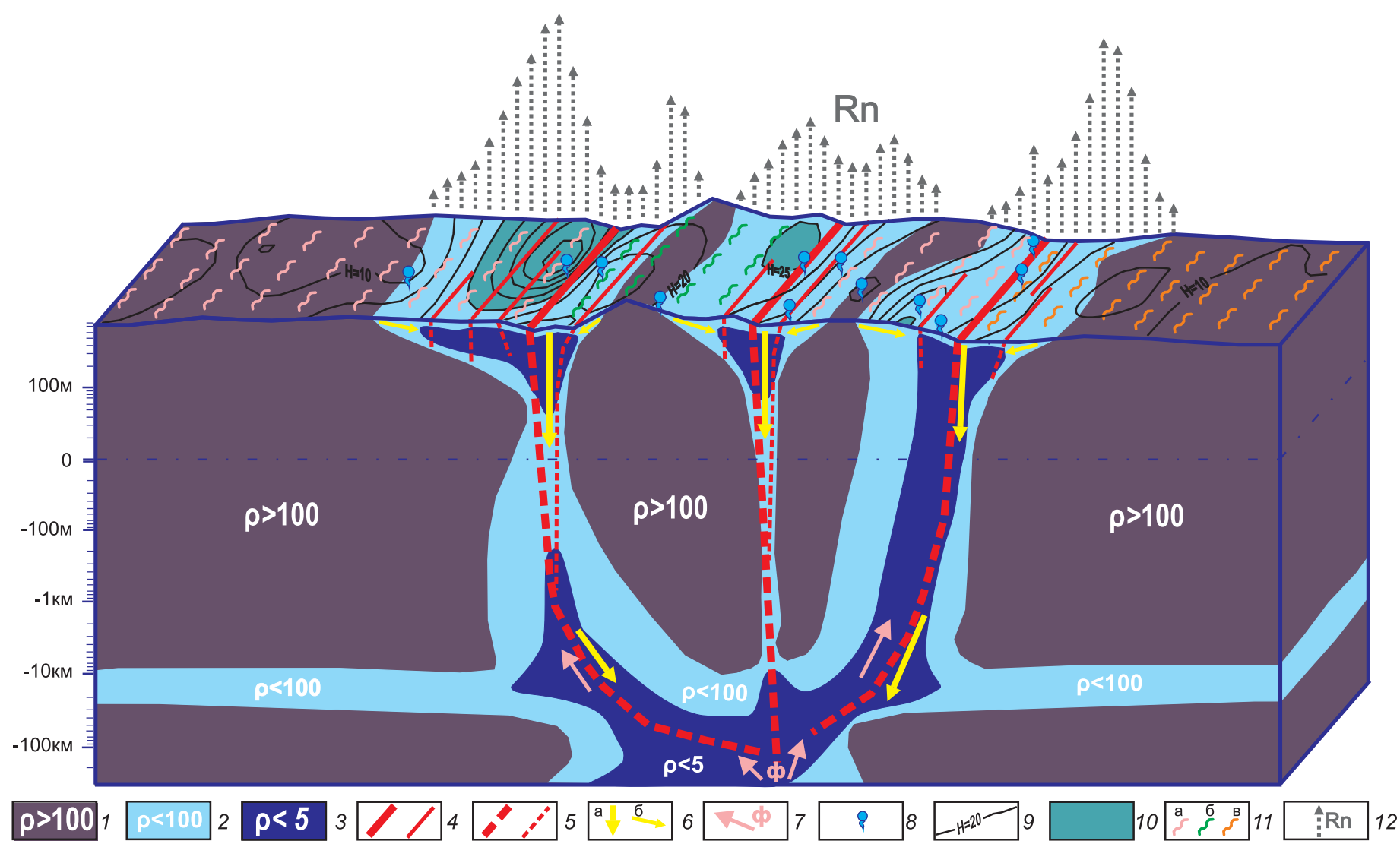

Рис. 21. Концептуальная геолого-геофизическая модель типичного для юга Восточной Сибири геодинамически активного участка земной коры, главным структурным элементом которого является межблоковая разломная система.

1 - слабонарушенные блоки; 2 - флюидопроницаемые межблоковые зоны; 3 - наиболее нарушенные и флюидонасыщенные участки межблоковых зон; 4-5 - крупные и мелкие разломы в разрезе (4) и на земной поверхности (5); 6 - направление миграции метеорных вод: a - субвертикальный нисходящий поток по зонам крупных разломов, б - субгоризонтальный близповерхностный поток от области питания к местам разгрузки; 7 - восходящий поток флюидов; 8 - естественный выход подземных вод на поверхность; 9 - распределение параметра $H$ (содержание в пробе воды суммы ионов сульфата и хлора, \%) в изолиниях; 10 - участки затрудненного водообмена (максимумы параметра $H$ ); 11 - разнотипные приповерхностные воды: а - кальций-магниевые, б - преимущественно натриево-калиевые, в магниево-кальциевые; 12 - выход радона (длина стрелки пропорциональна интенсивности эманаций).

Fig. 21. The conceptual geological-geophysical model of a segment of the crust which is typical of the southern regions of East Siberia. Its main structural element is the interblock fault system.

1 - slightly disturbed blocks; 2 - fluid-permeable interblock zones; 3 - highly disturbed, fluid-saturated segments of interblock zones; 4-5 - faults in the cross-section (4) and on the ground surface (5); 6 - directions of meteoric water migration: a - subvertical downward flow in zones of large faults, 6 - subhorizontal subsurface flow from feed areas to offloading areas; 7 - ascending flow of fluids; 8 - natural outlet of underground water; 9 - distribution of parameter $\mathrm{H}$ (sulphate and chlorine ions contained in water samples, \%) in isolines; 10 - areas of hindered water exchange (maximum values of parameter $\mathrm{H}$ ); 11 - near-surface water of different types: a - calcium-magnesium, 6 - mainly sodium-potassium, в magnesium-calcium; 12 - radon emanation (longer arrows show higher emanation intensity).

ми значениями удельного электрического сопротивления как вблизи поверхности, так и на глубине.

В итоге проведенный анализ показал, что использованные на трансекте Шертой - Красный Чикой методы, за редким исключением, оказались эффективны для изучения межблоковых зон земной коры. Это стало следствием привлечения в состав комплекса геофизических, гидрогеологических и морфометрических способов и приемов исследования земной коры, направленных на выявление ее структурных особенностей. Полученные каждым из методов результаты в той или иной степени отразили существование на юге
Восточной Сибири иерархически построенной системы нарушенных зон, по которым контактируют относительно массивные блоки. Вместе с тем вследствие многообразия условий проявления разнотипных и разноранговых межблоковых зон в земной коре они поразному отражаются в отдельных геофизических, морфотектонических и гидрогеологических признаках.

Анализ особенностей отдельных методов в плане выявления разломной структуры позволил установить, что в качестве необходимых составляющих методического комплекса по изучению межблоковых зон юга Восточной Сибири на данном этапе исследований сле- 
дует рекомендовать анализ современного рельефа с выделением его спрямленных элементов, малоглубинную электроразведку (СЭП или электротомография), глубинные магнитотеллурические зондирования и эманационную съемку. Исследование рельефа на количественной основе позволяет выделять пониженные участки с высокой степенью нарушенности приповерхностной части земной коры. Малоглубинная электроразведка и магнитотеллурические зондирования дают возможность выделить и оконтурить в широком диапазоне глубин проводящие зоны, которые представлены участками земной коры, нарушенными и проницаемыми для разнотипных флюидов. Эманационная съемка выделяет зоны интенсивной дегазации, причем локальные максимумы и минимумы объемной активности радона маркируют положение отдельных сместителей с проницаемыми или непроницаемыми для газа тектонитами. В зависимости от специфики поставленных задач в комплекс могут привлекаться дополнительные методы, позволяющие выявить природу тех или иных аномалий для углубленной интерпретации результатов основных видов исследования. Так, опробованный в пределах трансекта метод естественного электрического поля и гидрогеологические исследования позволяют понять природу геоэлектрических полей, оценить специфику проницаемости отдельных участков земной коры. В перспективе имеет смысл на эталонных участках наряду с основными видами геолого-геофизических работ провести сейсмические исследования, что позволит оценить целесообразность их использования для картирования внутренней структуры межблоковых зон.

\section{2. БАЙКАЛЬСКИЙ РИФТ В СТРУКТУРЕ МЕЖБЛОКОВЫХ ЗОН ЮГА ВОСТОЧНОЙ СИБИРИ}

Использование геофизических, морфотектонических и гидрогеологических данных по трансекту Шертой - Красный Чикой в совокупности с известными и собственными геолого-структурными материалами позволило получить новые сведения о тектоническом строении юга Восточной Сибири, что составляет предмет рассмотрения в данном разделе. Поскольку наиболее отчетливо структурные особенности земной коры проявляются на геодинамически активных участках, ниже выявленные закономерности иллюстрируются на примере Байкальского рифта. Главным при этом является рассмотрение структуры его центральной части с позиций зонно-блокового строения земной коры. Кроме того, преимущества комплексных исследований, а также проведение некоторых видов съемок с большей детальностью по сравнению с аналогичными работами предшественников позволили получить новые данные о глубинном строении рифта, параметрах и взаимоотношениях его отдельных структурных элементов.

Ширина рифта в районе трансекта составляет при- мерно 200 км, из которых две трети принадлежат юговосточному крылу и только одна треть - северо-западному (см. рис. 16). Это подчеркивает общую асимметрию глобальной границы между Сибирским и Забайкальским блоками литосферы, толщина которых составляет соответственно 130 и 90 км [Petit, Deverchere, 2006]. На трансрегиональном уровне Байкальский рифт представляют три разломные системы растяжения (Обручевская, Черско-Баргузинская и ДжидаВитимская), нарушающие земную кору на всю мощность, которая, согласно [Mats et al., 2001; Suvorov et al., 2002], увеличивается от 40 до 45 км при переходе от платформы к складчатому поясу. Поперечные размеры у трех межблоковых зон трансрегионального уровня вдоль трансекта примерно одинаковы ( $\approx 50$ км), но вклады в реализацию растяжения отличаются. Джида-Витимская зона отделена от разломных систем центральной части рифта высокоподнятым блоком хребта Хамар-Дабан и характеризуется общим наклоном к юго-востоку. Сбросовые перемещения, произошедшие по разломам древнего заложения, отличаются меньшей величиной и современной активностью по сравнению с двумя другими зонами трансрегионального уровня. Это выразилось в формировании относительно неглубокой Иволгино-Удинской впадины, повышенном тепловом потоке и умеренной современной сейсмичности. Джида-Витимская межблоковая зона представляет пример сателлитного участка растяжения, подобного тем, которые имеют место на северовосточном продолжении Байкальского рифта (например, Баргузинская впадина), а также в пределах других структур аналогичного типа в связи с дискретностью проявления деформаций в пространстве [Lesne et al., 2000; Gol'din et al., 2006]. Степень современной активности данного участка меньше, чем района Баргузинской впадины, что, вероятно, связано с интенсивным процессом локализации деформации, произошедшим в ходе растяжения земной коры по линии трансекта в Южно-Байкальской впадине [Seminsky, 2009]. Это сейсмически активная и самая глубокая из приосевых рифтовых впадин, образовавшаяся при интенсивных вертикальных перемещениях по Обручевской и Черско-Баргузинской разломным системам, которые наклонены навстречу друг другу и также относятся к пересеченным трансектом межблоковым зонам трансрегионального уровня.

На региональном уровне разломные системы представлены двумя-тремя крупными межблоковыми 30нами разломного типа, ширина которых в среднем составляет 15 км, а глубина проникновения оценивается величиной $\approx 20$ км. В сравнительно стабильных крупных блоках это глубина кровли регионально проявленного низкоомного слоя, а в пределах активных регионов - уровень проводящих участков у региональных зон, располагающихся на периферии разломных систем: Прихребтовой, Бортовой, Джида-Удинской и других (см. рис. 16, Г). В центральных частях Байкаль- 
ского рифта или Монголо-Охотской межблоковой границы глубина региональных разломных зон не может быть определена, так как они входят в состав магистральных сместителей трансрегионального или глобального уровня, которые проникают до подошвы коры или литосферы. На геоэлектрическом разрезе такие зоны представлены широкими проводящими участками, поскольку за счет интенсивной деструкции флюиды проникают в контактирующие блоки на большие расстояния. Как следствие, разломные системы в тектонически активном регионе, являясь одновременно и системами флюидными, представляют в целом электропроводящие области со сравнительно небольшими менее нарушенными участками (блоками), где сопротивление повышается до 1000 Ом·м.

Крайнее выражение данная закономерность имеет в приосевой части Байкальского рифта, что является следствием специфики его внутреннего строения. Вопервых, располагающийся между Обручевской и Черско-Баргузинской разломными системами собственно Байкальский блок рассекается в осевой части зоной регионального уровня, представляющей собой флюидопроводящий канал шириной $\approx 7-10$ км. На геоэлектрическом разрезе непрерывный участок самых низких сопротивлений (до 0.5 Ом·м) соединяет низы коры и слой электропроводящих осадков, заполняющих Байкальскую впадину (см. рис. 16, В-Г). Во-вторых, высокая степень флюидизации центральной части рифта в значительной степени определяется архитектурой сети и густотой региональных межблоковых зон, представляющей в разрезе типичный пример участка растяжения земной коры. Так, по обе стороны от крутонаклоненного флюидизированного канала располагаются региональные разломные зоны, которые принадлежат к Обручевской и Черско-Баргузинской системам, «падают» навстречу друг другу, причем периферийные Прихребтовая и Бортовая зоны создают чашеобразный внешний контур области интенсивного растяжения за счет заметного выполаживания начиная с глубин $\approx 20$ км. Подобная архитектура сети региональных разломов и существенные размеры зон их влияния в совокупности с доминированием условий растяжения коры приводят к ее интенсивной флюидизации в пределах выделяющегося естественного контура за счет подтока растворов из мантии и проникновения метеорных вод с поверхности.

Характерной особенностью строения межблоковых дизъюнктивов регионального уровня, выделяющейся на западном плече Байкальского рифта в связи с доминированием перемещений сбросового типа, является наличие фронтальных и тыловых разломных зон, имеющих в среднем ширину $\approx 5$ км и разделенных менее деформированными блоками (см. рис. $6, A-B)$. Интенсивные подвижки по главному сместителю вызывают деструкцию поднятого блока, которая от поверхности проникает в глубину, стремясь достичь фронтальной зоны главных смещений (см. рис. 7). Судя по положению участков пониженных сопротивлений под каждой из тыловых зон в Прихребтовой, Приморской и Морской региональных зонах (см. рис. 6, Г), это происходит на глубинах $\approx 10$ км. Представляется, что данный процесс, наряду с разрушением зацепов на фронтальных поверхностях смещения, может быть причиной существования двух полос эпицентров землетрясений, попадающих в контуры оз. Байкал и приуроченных к Морской и центральной региональным разломным зонам на глубинах 10-22 км.

На локальном уровне каждая из описанных зон повышенной концентрации разрывов представлена иерархией разломов, ряд которых был детально изучен на территории Приольхонья. Поисковый характер геофизических и гидрогеологических работ предопределил выбор в качестве объектов исследования разломов, доступных для непосредственного наблюдения в береговых обрывах оз. Байкал и поэтому в большинстве своем уже изученных предшественниками [Pavlovsky, 1969; Pleshanov, Chernov, 1968; Florensov, 1977; Kashik, 1978; Zamaraev et al., 1979; Pleshanov, Romazina, 1981; Kuklei, 1985; Lobatskaya, 1987; Mazukabzov, Sizykh, 1987; Sherman, Dneprovsky, 1989; Logachev, 1994; Seminsky, 1994, 2003; Melnikov et al., 1994; Levi et al., 1997a; Delvaux et al., 1997; Mats et al., 2001; Lunina et al., 2002; Cheremnykh, Markovtseva, 2007; Cheremnykh, 2010; Seminsky, Cheremnykh, 2011; and others]. Наши наблюдения подтвердили их основные выводы о древнем заложении, многоэтапности подвижек и высокой нарушенности горных пород вследствие выветривания и активизации перемещений на современном рифтовом этапе развития. В связи с этим главной структурной особенностью региона является высокая средняя плотность трещин (10 тр./пог. м), на фоне которой значениями $\approx 25$ тр./пог. м выделяются разломные зоны, относящиеся по специфике внутреннего строения, как правило, к зрелым стадиям развития - поздней дизъюнктивной или стадии полного разрушения (см. рис. 4). Несмотря на высокую степень нарушенности, проницаемость разломных зон имеет крайне неравномерный характер. Обычно она низка в приосевых участках проявления крупных сместителей из-за широкого распространения продуктов выветривания и глинки трения и высока на периферии разломной зоны, где господствуют разрывы оперения и открытая трещиноватость.

Оригинальный характер носят результаты исследований локальных разломных зон на дне оз. Байкал, полученные в процессе наблюдений с борта обитаемых подводных аппаратов, а также данные глубоководного бурения осадочной толщи. Однако в плане изучения коренного подводного склона структурные особенности разломов на качественном уровне аналогичны выявленным в пределах сухопутной территории Западного Прибайкалья. В зоне Морского сброса они по большей части также наследуют древние выветрелые зоны и проявляются в виде крупных плоскостей скольжения 
с субвертикальными штрихами и бороздами скольжения (см. рис. 9). Главным отличием является более высокая интенсивность процесса деструкции, свойственная приосевой части рифта и проявляющаяся в широком распространении сбросов не только продольной, но и поперечной ориентировки, а также их контрастной выраженностью в рельефе в виде крутых уступов, осложненных массовыми проявлениями гравитационных процессов (обвалы, осыпи, оползни). Выходы активных разломов к поверхности в пределах осадочной ванны отчетливо проявлены уступами в рельефе дна для бортовых разломных зон и менее контрастно - на субгоризонтальном ложе. Непосредственно в самой толще слабосцементированных отложений это закономерно организованные зоны повышенной трещиноватости, представляющие раннюю стадию развития разлома (см. рис. 10), который в кристаллическом основании может быть проявлен в виде единой поверхности сбросовых или сдвиговых смещений. Вследствие тонкодисперсного характера слабосцементированных осадков трещины и более крупные разрывы в разломных зонах находятся в латентном состоянии, что, вероятно, отражается на проницаемости толщи. Вопрос о масштабах разгрузки на дне оз. Байкал флюидов, проникающих по центральной зоне растяжения из глубин земной коры к подошве осадков, может быть решен обоснованно лишь после проведения дополнительных глубоководных исследований. Что же касается выхода газов, то о его значительных объемах можно судить по приуроченности к данной зоне грязевых вулканов, включая «К-2», который располагается практически на трассе профиля «Западный берег - Восточный берег» [Isaev, 2001; Klerkx et al., 2006; Schmid et al., 2007].

Как следует из приведенного выше описания, основной количественной характеристикой межблоковых зон, изученных в каждом из масштабов при комплексных исследованиях на трансекте, была их ширина. Это позволило установить место изученного ряда разноранговых структур в иерархии межблоковых зон, выявленной ранее для Центральной Азии в целом [Seminskii, 2008] и приведенной в верхней части таблицы. Она была выявлена в результате анализа распределения величины среднегеометрического размера зон $\left(l_{c p}\right)$, рассчитываемого для каждой из них как квадратный корень из площади $(s)$, занимаемой зоной на одной из схем зонно-блоковой структуры, две из которых приводятся в данной статье (рис. 1 и 22). Иерархия включает 11 уровней (3 глобальных, трансрегиональный, 3 региональных и 4 локальных), причем отношение среднегеометрического размера последующей по рангу зоны к размеру предыдущей колеблется около значения $\mu_{s}=2.2$ (где $\mu_{s}$ - масштабный инвариант).

В рассматриваемом Азиатском регионе к глобальному рангу I относится граница между Евразийской и Индо-Австралийской литосферными плитами. Гло- бальный ранг II представлен серией межблоковых зон, в том числе той, которая является северной границей Амурской плиты (см. рис. 1, № 18) и протягивается из Монголии на северо-восток до побережья Охотского моря. В ее состав входят сегменты - глобальные зоны III ранга, развивающиеся в позднем кайнозое в режимах левого сдвига или растяжения. Одной из зон растяжения является Байкальский рифт, пересеченный трансектом Шертой - Красный Чикой, что позволяет выделенную в его пределах непрерывную ранговую последовательность крупных межблоковых зон считать соответствующей $I V-V I$ рангам, как это представлено в нижней части таблицы. Использование определенных для Центральной Азии величин площади межблоковых зон каждого ранга и ширины их представителей на трансекте $\left(M_{c p}\right)$ позволяет перейти к длине $\left(L_{c p}\right)$, оценив на некоторых примерах достоверность рангового соответствия с помощью схемы (рис. 22). Действительно, положение и протяженность осей у четырех выбранных для примера межблоковых зон III-VI рангов (таблица) не противоречат структурной ситуации, которая отражена на схеме зонно-блоковой делимости Прибайкалья, построенной на базе карты [The Neotectonic Map..., 1982].

Таким образом, на данном этапе исследования, когда исходные для несложных вычислений оценки площадей являлись усредненными для территории Центральной Азии в целом, можно считать, что место изученных на трансекте структур в общей иерархии межблоковых зон определено правильно. Более того, с использованием, кроме площади, средних глубин проникновения структур в земную кору $\left(H_{c p}\right)$, которые обычно контролируются существующими в ней субгоризонтальными неоднородностями [San'kov, 1989; Logachev, 1991], в пределах трансекта для межблоковых зон III-VI рангов вычислены среднегеометрические размеры как кубический корень из их объема $\left(V_{c p}\right)$ (таблица). Эти величины в силу различия в значениях входящих параметров меньше размеров зон, определенных для тех же рангов по площади. В то же время изменение в 2.2 раза среднегеометрического размера зон при переходе от ранга к рангу имеет место и при рассмотрении их объемов. Совпадение величины масштабного инварианта $\left(\mu_{V}\right)$ до десятых долей для зон III и $I V, I V$ и $V, V$ и $V I$ рангов, а также со средней величиной $\mu_{s}$ можно считать случайным, однако существование общей закономерности, впервые подтвержденной при анализе объемов для широкого спектра межблоковых структур Прибайкалья, сомнений не вызывает.

Полученные параметры зон, а также среднегеометрические размеры и величина масштабного инварианта для блоков (2.1), определенные ранее при количественной обработке разномасштабных схем делимости Центральной Азии [Seminskii, 2008], являются необходимой основой для создания иерархической модели зонно-блоковой структуры литосферы на количественной базе. Однако на данном этапе исследований 
K.Zh. Seminsky et al.: Interblock zones in the crust of the southern regions of East Siberia...

Положение крупных дизъюнктивных структур, пересеченных трансектом Шертой - Крестовский, в общей иерархии межблоковых зон Центральной Азии

Positions of large faults (crossed by the Shertoy - Krestovsky transect) in the overall hierarchy of interblock zones of Central Asia

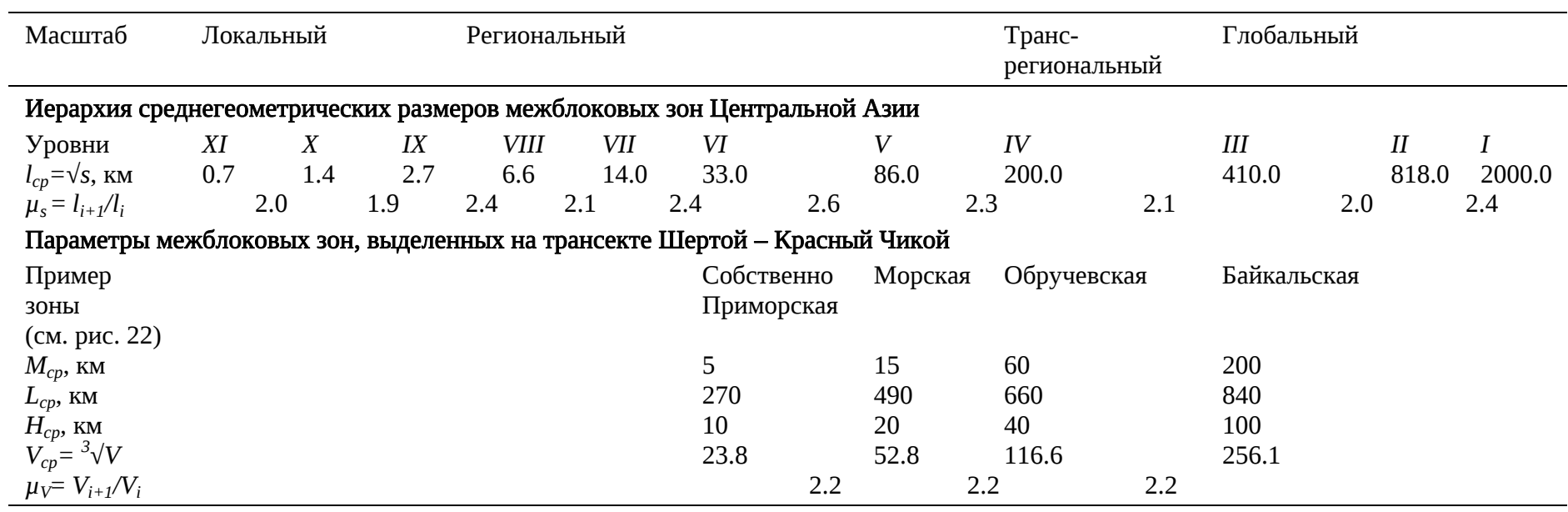

она была бы слишком упрощенной, поскольку, кроме численных соотношений, в ее базу должны закладываться принципиальные особенности делимости литосферы в геодинамических обстановках, отличающихся параметрами действующих внешних сил (направленность, интенсивность и пр.) и характеристиками деформируемого субстрата (реология, степень структурно-вещественной неоднородности и пр.). Эти сведения могут быть получены и обобщены на основе проведения исследований, подобных представленным выше, но при этом охватывающим необходимое разнообразие геодинамических обстановок, характерных для межплитных взаимодействий.

Как следствие, на данном этапе целесообразно обобщить особенности взаимоотношений зон и блоков, характерные для ключевого на юге Восточной Сибири Байкальского региона, считая их необходимой составляющей для построения в дальнейшем тектонофизической модели зонно-блоковой структуры литосферы Земли. По данным многолетних исследований Н.А. Логачева [Logachev, 2003], поздний этап тектогенеза начался в Прибайкалье 70-65 млн лет назад и, судя по результатам тектонофизических исследований [Seminsky, 2009], мог продолжаться вплоть до настоящего времени в едином режиме блоковых перемещений. Определяющей особенностью геодинамической обстановки формирования зонно-блоковой структуры региона можно в первом приближении считать относительное перемещение Забайкальского блока литосферы в генерализованном восточном направлении (см. рис. 1). Это приводит к активным, сопровождающимся высокой сейсмичностью, левосдвиговым перемещениям на его границе с северными блоками (зона № 18) и менее выраженным движениям правого знака на южной границе (зона 14-2). Важную роль в этой ситуации играет структурно-вещественная неоднородность деформируемого субстрата, которая, предопре- деляя форму блоков, формирует в соответствии с направлениями их движения закономерные динамические обстановки на контакте со смежными блоками. Так, форма южного выступа древнего Сибирского кратона предопределила северо-восточную ориентировку и условия растяжения на Байкальском фрагменте межблоковой границы, который был пересечен трансектом Шертой - Красный Чикой (см. рис. 2, Б). Как следствие, многие крупные и мелкие межблоковые зоны изученного региона представляют собой древние разломы, активизированные в кайнозое.

Главной особенностью зонно-блоковой структуры, выделенной на юге Восточной Сибири при совместной интерпретации площадных морфотектонических (см. рис. 1, 2) и комплексных профильных (см. рис. 4-6; 11, $14,15)$ исследований, является ее принципиальное соответствие фундаментальной модели делимости литосферы, предложенной М.А. Садовским [Sadovsky et al., 1987]. Это заключение не является тривиальным, поскольку выделение зонно-блоковой структуры в данном виде представляется непростой задачей для многих регионов. Причиной ее успешного решения на территории юга Восточной Сибири стало не только применение эффективного методического комплекса. Главным в данном случае является характер тектонического развития региона, результаты которого получили отчетливое выражение в современном рельефе и подземной гидросфере, исследование которых было определяющим для выявления зонно-блоковой структуры на разных уровнях земной коры. На поверхности и геоэлектрических разрезах (см. рис. 2, 15-16) отчетливо видна система широких интенсивно нарушенных и насыщенных флюидами зон, между которыми располагаются относительно массивные высокоомные блоки. Если судить о строении других активных регионов мира, то столь отчетливо картина зонно-блоковой структуры земной коры в материалах МТЗ про- 


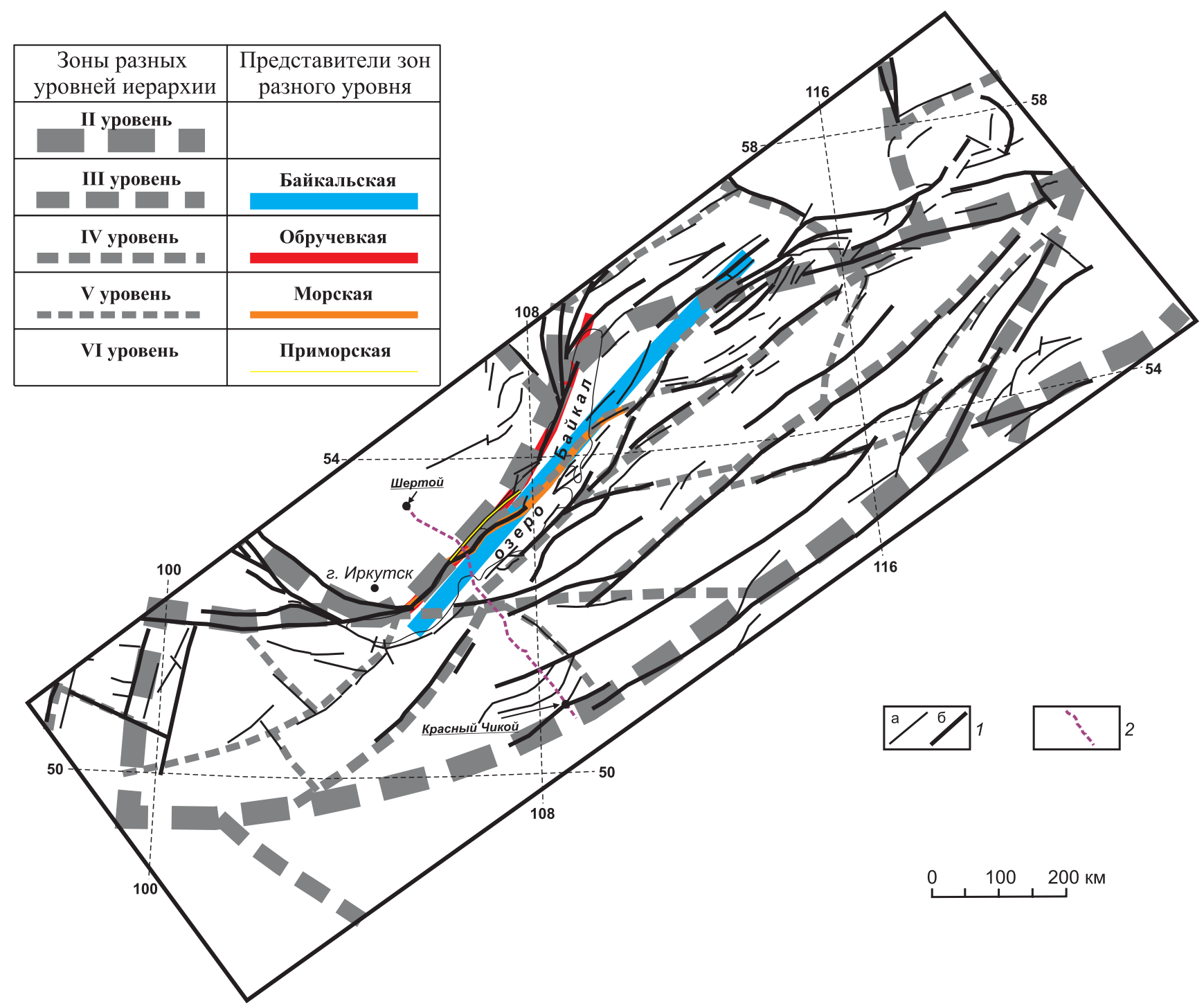

Рис. 22. Положение на схеме блоковой делимости Прибайкалья [Seminskii, 2008] осей разноранговых межблоковых зон (цветные линии), размеры которых были определены в ходе интерпретации исследований на трансекте Шертой - Красный Чикой.

1 - разноранговые разломы согласно карте [The Neotectonic Map..., 1982]; 2 - линия трансекта.

Fig. 22. Positions of axes of interblock zones of various ranks (coloured lines) in the scheme of block divisibility of the Pribaikalie published in [Seminskii, 2008]. Dimensions of the interblock zones were determined by interpretation of data obtained at the Shertoy-Krasny Chikoy transect.

1 - faults according to [The Neotectonic Map..., 1982]; 2 - transect.

является далеко не всегда [Hoffmann-Rothe et al., 2004; Bataleva, 2005; Chen et al., 2007; Xiao et al., 2011]. B этом плане имеет смысл в заключении данного раздела подчеркнуть главные черты делимости литосферы юга Восточной Сибири, выявленные в ходе комплексных исследований на трансекте Шертой - Красный Чикой и схематично отраженные в виде простой геолого-геофизической модели на рис. 21.

Важной особенностью сети межблоковых зон земной коры является ее замкнутость. Этот вывод согласуется с ранее полученными данными по блоковому строению земной коры [Krasny, 1984, 2003; Sadovsky et al., 1987; Glasko, Rantsman, 1995; Gol'din, 2002; Cheremnykh, 2003; Gatinsky, Rundquist, 2004; Seminskii, 2008; Sherman, 2012; and others] и структуре деформированных эквивалентных материалов [Kondratiev et al., 1985; Rodionov et al., 1986; Sobolev, Asatryan, 1990; Ponomarev et al., 1995; Makarov, 2007; and others]. Вместе с тем замкнутость зонно-блоковой структуры проявляется не в каждом из полей, обычно используемых для решения различных задач геодинамики, включая и поле нарушенности верхней части коры в 
областях сочленения межблоковых зон (см. рис. 2, Б). Это является одним из главных факторов неактивного использования концепции зонно-блоковой делимости в большом диапазоне масштабов, располагающихся между глобальным уровнем крупных литосферных плит и локальным уровнем делимости коренных выходов скальных пород. Наиболее отчетливо данная особенность зонно-блоковой структуры выражена в полях распределения самых подвижных агентов - воды и газов, что в отношении флюидов подтверждается распределением УЭС в разрезе верхней коры на примере трансекта Шертой - Красный Чикой (см. рис. 16, $B)$. Как следствие, модели строения земной коры, представленные блоками и окружающими их со всех сторон зонами, наиболее активно используются специалистами, занимающимися углубленными исследованиями распределений подземных вод, флюидов и газов [Stepanov, 1959; Kissin, 1996; Gufeld et al., 2011; and others].

Среди сетей межблоковых зон могут выделяться их виды, отличающиеся предпочтительной ориентировкой ключевых элементов. Материалы, полученные по трансекту Шертой - Красный Чикой, схематично отраженные на рис. 21, подтверждают представления М.Н. Бердичевского [Berdichevsky et al., 1999] о доминировании в регионе ортогональной сети нарушенных зон. Как показали наши более детальные исследования, это предопределяет плитообразную в первом приближении форму блоков, занимающих субвертикальное и субгоризонтальное положения внутри, соответственно, подвижных зон (например, Байкальская) и блоков (например, Сибирский) 1-го порядка. Наклонные зоны имеют подчиненное значение и главным образом проявляются в специфических условиях деформации (например, растяжение) на участках выполаживания крутых зон у горизонтальных границ (например, граница Мохо).

Еще одной важной особенностью зонно-блоковой структуры является ее строгая иерархическая соподчиненность, которая отражается в полученных для юга Восточной Сибири материалах на качественном и количественном уровнях. В качественном отношении это структурная организация, основу которой составляет система блоков, вложенных друг в друга. Как следствие, существуют характерные размеры зон и блоков, соответствующие определенным уровням иерархии зонно-блоковой структуры. В количественном отношении это выражается в существовании масштабного инварианта, согласно которому среднегеометрические размеры характерных элементов зонно-блоковой структуры, располагающиеся на смежных уровнях, отличаются друг от друга примерно в два раза. На материалах трансекта, где имелась возможность приближенно оценить вертикальный размер разноранговых межблоковых зон (т.е. глубину проникновения в земную кору), показано, что выявленная ранее для территории Центральной Азии закономерность [Seminskii,
2008] справедлива в трехмерном выражении.

Значения масштабных инвариантов, среднегеометрические размеры зон и блоков, полученные для Центральной Азии в целом и юга Восточной Сибири в частности, являются статистическими оценками, усредненными для больших групп элементов зонно-блоковой структуры, и в этом качестве имеют преимущественно теоретическое значение. Однако в практическом плане более важными являются соотношения размеров зон и блоков, характерные для участков земной коры, отличающихся условиями формирования и развития зонно-блоковой структуры. Таблица дает представление об уровнях количественных оценок, характерных для территории юга Восточной Сибири. Кроме этого, следует остановиться на характеристике соотношений размеров зон и блоков на качественном уровне, поскольку эти наблюдения справедливы и для других природных регионов.

Соотношение размеров зон и блоков на одном уровне иерархии определяется степенью геодинамической активности рассматриваемого участка земной коры (см. рис. 21). В слабоактивных регионах блоки по размерам доминируют над зонами. На участках с интенсивными проявлениями тектонических перемещений межблоковые зоны соизмеримы с блоками и даже могут превосходить их по размерам, что особенно характерно для верхней части земной коры вследствие «разрыхления» массива горных пород при разгрузке напряжений у свободной поверхности (например, юговосточная половина сегмента Шертой - Крестовский на рис. 6). Наглядным примером подобной структурной ситуации на локальном уровне является коренной выход, в котором обнажается разломная зона, представленная интенсивно нарушенными породами с включениями сравнительно массивных блоков (см. рис. 4, A-3).

В общем случае параметры и строение межблоковых зон определяются направлением, интенсивностью и продолжительностью действия сил, приложенных к деформируемому объему земной коры, при подчиненном влиянии его структурно-вещественного наполнения. В кайнозойской геодинамической обстановке юга Восточной Сибири они являются следствием деструктивного, а не конструктивного процесса. На глобальном и трансрегиональном уровне это разломные системы растяжения и сдвига, первые из которых отличаются продвинутыми стадиями зрелости внутренней структуры и высокой геодинамической активностью. В региональном и локальном масштабах межблоковые структуры представляют собой разломные (сбросовые и сдвиговые) зоны в широком понимании термина, когда в их границы входят разрывы 2-го порядка, генетически связанные с формированием главного сместителя (1-го порядка). В зависимости от активности и продолжительности однонаправленного перемещения смежных блоков разграничивающая их зона может представлять раннюю, позднюю дизъюнктивные ста- 
дии развития разлома, а также стадию полного разрушения с явно выраженным магистральным сбросом или сдвигом.

Представленная выше тектонофизическая трактовка межблоковых зон, основанная на конкретных геолого-геофизических материалах по югу Восточной Сибири, обусловливает существование широких зон контактирования блоков, границы которых, как правило, не являются резкими. Эта особенность принятой модели зонно-блоковой структуры не противоречит данным об узких границах контактирования блоков, исследованных многими предшественниками [Glasko, Rantsman, 1995; Kostyuchenko et al., 2002; Shebalin et al., 2002; Kurlenya et al., 2005; Kocharyan et al., 2010; and others]. Последние представляют собой наиболее зрелые стадии развития межблоковых структур, характеризующиеся явно выраженной локализованностью перемещений и деформаций в узкой полосе магистрального сместителя. Процент подобных межблоковых зон в конкретных структурных ситуациях различен, зависит от продолжительности однонаправленного внешнего воздействия и в общем случае увеличивается сверху вниз в зонно-блоковой иерархии, т.е. от глобального масштаба к локальному [Seminskii, 2008]. Предельной в данном случае является структурная ситуация, которая характерна для скальных выходов пород в геодинамически активных регионах: ширина открытых и, тем более, латентных трещин несоизмеримо меньше размеров ненарушенных блоков, вычленяемых этими трещинами. Необходимо отметить, что в проблеме выделения межблоковых зон существуют и методические сложности. Поскольку истинными являются границы, которые выделяются по распространенности разрывов 2-го по отношению к зоне порядка, анализируемый признак должен отражать положение именно таких структур. В других случаях оценка ширины занижается, что необходимо учитывать при решении задач, поставленных перед исследованием.

\section{6. ЗАКЛЮЧЕНИЕ}

Исследования вдоль трансекта Шертой - Красный Чикой были направлены на выделение и анализ внутреннего строения разноранговых межблоковых зон на юге Восточной Сибири в области контактирования Сибирского и Забайкальского блоков литосферы. По сравнению с предшествующими, проведенными по близким трассам геолого-геофизическими исследованиями, комплекс методов, реализованных в пределах трансекта, был ориентирован на выделение активных структур, которые проявлены в открытых разрывах и трещиноватости и, как следствие, характеризуются высокой проницаемостью для воды и газов. Кроме того, в рамках отдельных методов работы отличались большей детальностью (СЭП, ЕП, магниторазведка, MT3, линеаментный анализ рельефа) или применени- ем новой аппаратуры (МТ3). Радон-тороновая съемка в пределах трансекта Шертой - Красный Чикой выполнена впервые. Интерпретация полученных данных с единых тектонофизических позиций позволила решить три поставленные перед исследованием задачи и получить в рамках каждой из них результаты, представленные ниже.

1. Уточнены принципиальные особенности геологического строения земной коры вдоль трансекта Шертой - Красный Чикой, выявлена реальная картина тектонической делимости, и установлено ее соответствие тектонофизическим представлениям о иерархически организованной зонно-блоковой структуре литосферы. В приповерхностной части и в разрезе коры до глубины 30 км отчетливо проявлено ее деление на относительно слабонарушенные блоки, которые контактируют по широким зонам и слоям, отличающимся повышенной дислоцированностью и флюидонасыщенностью. Высокая интенсивность процессов деструкции и флюидизации коры изученного региона на последнем этапе тектогенеза стала главной причиной проявления зонно-блоковой делимости в ее относительно простом виде, отчетливо отражающемся в плане и на разрезах. В геофизических полях разной природы (в первую очередь, чувствительных к наличию воды и газов) межблоковые зоны образуют замкнутую сеть, отличительной особенностью которой в вертикальном разрезе является ортогональность. Блоки по своей форме в первом приближении являются плитами, занимающими субгоризонтальное положение в относительно стабильных регионах юга Восточной Сибири (например, южная часть Сибирской плиты) и субвертикальное - в областях кайнозойской активизации (например, Байкальский рифт). В то же время при более детальном рассмотрении межблоковые структуры обычно расширяются к поверхности и в тектонически активных зонах 1-го порядка могут превышать поперечные размеры смежных слабонарушенных блоков, соответствующих им по уровню иерархии.

Зонно-блоковая структура литосферы юга Восточной Сибири характеризуется строгой иерархической соподчиненностью, которая проявлена на качественном и количественном уровнях в пространственных взаимоотношениях межблоковых структур. Сравнительно крупные зоны оконтуривают соответствующий им по рангу блок, который разделен меньшими по размеру зонами на более мелкие составляющие, что в единой иерархии образует систему блоков, как бы «вложенных» друг в друга. На основе комплексной интерпретации геолого-геофизических материалов по трансекту Шертой - Красный Чикой для земной коры юга Восточной Сибири выявлены и количественно охарактеризованы один из глобальных (III), трансрегиональный $(I V)$ и три региональных $(V-V I I)$ уровня межблоковых зон в единой иерархии аналогичных структур литосферы Центральной Азии. Для обозначенных выше уровней среднегеометрические размеры 
зон впервые рассчитаны с учетом глубины их проникновения в земную кору и показано, что масштабный инвариант 2.2, установленный ранее для площадных оценок, справедлив и при рассмотрении объемов межблоковых структур.

Специфика внутреннего строения межблоковых зон земной коры юга Восточной Сибири определяется направленностью, продолжительностью и интенсивностью действия внешних сил и в меньшей степени структурно-вещественной неоднородностью субстрата земной коры. На кайнозойском этапе они развивались главным образом в режимах растяжения и сдвига, что привело к формированию иерархии структур, представленной межплитной границей, разломными системами и разноранговыми разломными зонами в широком тектонофизическом понимании. Состояние внутренней структуры межблоковых зон в основном соответствует поздним стадиям структурообразования, характеризующимся наличием магистральных сместителей или их сегментов, что явилось следствием унаследованного развития древних крутопадающих дизъюнктивов в однотипных условиях деформирования. На современном этапе тектогенеза деструкция земной коры происходит наиболее интенсивно в пределах Байкальского рифта, что, наряду с большим объемом опубликованной геолого-геофизической информации по хорошо изученному региону, позволило выявить особенности его строения с позиций представлений о зонно-блоковой делимости литосферы.

2. Байкальская межблоковая зона принадлежит к нижнему из глобальных уровней иерархии в зонноблоковой структуре Азии и развивается в режиме растяжения при контактировании Сибирского и Забайкальского блоков литосферы. Вдоль трассы трансекта она имеет ширину примерно 200 км и на трансрегиональном уровне иерархии выражена Обручевской, Черско-Баргузинской и Джида-Витимской разломными системами. Первые две из них ограничивают с запада и востока опущенный блок Байкальской впадины и, таким образом, составляют главный участок растяжения литосферы. Второй участок представлен Джида-Витимской разломной системой, отделен от первого высокоподнятым Хамар-Дабанским блоком и в геоморфологическом отношении на трассе трансекта выражен Иволгино-Удинской впадиной. Вследствие локализации деформации в смежном районе ЮжноБайкальской впадины деструктивный процесс здесь проявляется в меньшей степени, хотя индикаторы современной активности - сейсмичность, тепловой поток, газовые эманации и др. - создают в Джида-Витимской зоне явно выраженные максимумы, которые отличают ее от смежной территории Забайкальского блока.

Каждая из разломных систем имеет ширину примерно 50 км и состоит из региональных межблоковых зон, наиболее интенсивно развивающихся в пределах байкальского участка растяжения земной коры. По типу внутреннего строения они представляют зоны крупных разломов: Прихребтового, Приморского и Морского - в Обручевской системе, а также Бортового и Дельтового - в Черско-Баргузинской системе. Прихребтовая и Бортовая разломные зоны, занимающие периферийное положение в каждой из систем, выполаживаются в направлении оси рифта с глубин примерно 20 км, что придает характерный «чашеобразный» профиль участку наиболее интенсивного растяжения в Прибайкалье. Высокая степень деструкции на фоне общего разуплотнения коры приводит к насыщению этого чашеобразного участка флюидами за счет проникновения воды и глубинных растворов в региональные разломные зоны и, частично, в смежные блоки, которые также принадлежат к внутренней структуре Обручевской и Черско-Баргузинской разломных систем. Находящийся между ними блок Байкальской впадины в этом отношении не является исключением, так как по оси нарушен зоной регионального уровня, где вследствие локализации растяжения процесс флюидизации, если судить по высокой электрической проводимости субстрата, проявлен наиболее интенсивно. Зона аномально низких сопротивлений имеет ширину порядка 7-10 км и не обнаруживает тенденции к резкому сужению в низах коры, что позволяет на данном этапе исследований считать ее главным каналом для миграции глубинных флюидов к поверхности.

Локальные межблоковые зоны Прибайкалья составляют внутреннее строение активных структур регионального уровня и также являются разломами в их широком тектонофизическом понимании. В осадках оз. Байкал они выражены закономерно организованными зонами повышенной трещиноватости, отражающими раннюю стадию развития разлома, а на подводном склоне и береговых территориях - дизъюнктивами поздних стадий, представленных сместителями магистрального типа или их сегментами. Как правило, эти разломы наследуют более древние тектонические нарушения, выраженные линейными корами выветривания, что создает сложные для интерпретации геофизические аномалии. В наиболее общем случае приосевые части таких зон, слабопроницаемые для воды и газов, характеризуются средними или даже фоновыми значениями геофизических параметров, тогда как аномалии располагаются в крыльях, нарушенных сетью открытых разрывов. Общий рисунок осложняют частные вариации параметров, связанные с наличием межблоковых зон 2-го порядка.

3. Опыт, приобретенный в ходе исследований по трансекту Шертой -Красный Чикой, показал, что реализованный комплекс методов характеризуется высокой информативностью при выделении и анализе внутреннего строения разноранговых межблоковых зон, экспрессностью полевых измерений и возможностью применения в разнообразных условиях юга Восточной Сибири, отличающихся недостаточной обнаженностью пород для проведения прямых геолого- 
структурных наблюдений. Он включает методы, которые удачно дополняют друг друга, позволяя исследовать необходимый набор свойств межблоковых зон. Анализ рельефа, в т.ч. и линеаментный, дает возможность выявить пониженные участки с высокой степенью нарушенности земной коры. Гидрогеологические исследования позволяют оконтуривать приповерхностные участки выходов подземных вод трещинножильного типа с высоким процентным содержанием суммы сульфат- и хлор-ионов, которые соответствуют нарушенным проницаемым зонам. Эманационная съемка выявляет зоны интенсивной дегазации и активных перемещений, причем локальные максимумы и минимумы объемной активности радона маркируют положение отдельных сместителей с проницаемыми или непроницаемыми для газа тектонитами. Электропрофилирование и магнитотеллурическое зондирование позволяют выделить и оконтурить в широком диапазоне глубин проводящие зоны, которые представлены нарушенными вследствие блоковых взаимодействий и проницаемыми для флюидов участками земной коры. Отрицательными аномалиями естественного электрического поля выделяются древние разломы с графитовой минерализацией, по которым нередко происходят современные тектонические перемещения.

Сложность интерпретации комплексных данных заключается в том, что отдельными методами выявляются разные особенности межблоковых зон, которые в зависимости от условий формирования и развития могут отличаться по степени неоднородности внутреннего строения. На данном этапе исследований границы межблоковых зон могут в первом приближении определяться по усредненному положению разнотипных аномалий. При этом в отличие от традиционной методики, основанной на использовании среднеквадратичного отклонения, эффективным критерием, определяющим наличие аномалии, является отклонение геофизического поля от его среднего значения. В дальнейшем необходимо проведение детальных исследований, позволяющих установить специфику проявления в каждом из полей межблоковых зон, отличаю- щихся 1) типом, рангом и степенью активности; 2) свойствами заполнителя зон и вмещающего их субстрата; 3) особенностями влияния внешних факторов (например, планетарного характера). Сопоставление результатов работ подобного типа позволит уточнить представленные в статье концептуальные модели проявления межблоковых зон в отдельных геолого-геофизических полях. Это максимально приблизит их к действительности и повысит эффективность применения в регионах, где обнаженность пород недостаточна для использования прямых методов выделения межблоковых зон земной коры.

\section{7. БЛАГОДАРНОСТИ}

Авторы благодарны руководителю программы СО РАН ОНЗ-7 академику РАН М.И. Эпову и заведующему лабораторией геоэлектрики ИНГГ СО РАН, доктору физ.-мат. наук Е.Ю. Антонову за неизменные поддержку, внимание и интерес к полученным результатам. Большую помощь в организации и проведении исследований оказали генеральный директор Восточного геофизического треста, доктор геол.-мин. наук A.В. Поспеев и генеральный директор Иркутского электроразведочного предприятия, канд. геол.-мин. наук Ю.А. Агафонов. В геолого-геофизических работах активное участие принимали сотрудник НППГА «Луч» Ю.Н. Колычев, сотрудники ИЗК СО РАН канд. геол.-мин. наук С.А. Борняков, канд. геол.-мин. наук Я.Б. Радзиминович, ведущий инженер Ю.П. Бурзунова и ст.-лаборант А.А. Решилова, а также студентыгеофизики Читинского государственного университета под руководством канд. геол.-мин. наук Д.Л. Авгулевича, которым авторы статьи выражают искреннюю благодарность.

Работы выполнены при поддержке РФФИ (проект № 12-05-00322), программы фундаментальных исследований СО РАН (ОН3-7.6) и ФЦП «Научные и научно-педагогические кадры инновационной России на 2009-2013 годы» (соглашение № 14.В37.21.0583).

\section{8. ЛИТЕРАТУРА}

Albul S.P., Babushkin V.D., Borevsky B.V., Verigin N.N., Volod'ko I.F., Ivanov V.N., Kerkis E.E., Kiryukhin V.A., Klimentov P.P., Kononov V.M., Konoplyantsev A.A., Kruglikov N.M., Lekhtimyaki E.V., Maksimov V.M., Marshalov A.F., Matveev B.K., Matveeva E.S., Novozhylov V.N., Ogilvi A.A., Odnopozov V.L., Onin N.M., Ostroumov B.P., Padukov V.A., Plotnikov N.I., Pozin E.P., Semenov S.M., Khokhlovkin D.M., Yazvin L.S., Yakovlev A.M., 1979. Guidebook for Hydrogeologist. Nedra, Leningrad, Volume 1. 512 p. (in Russian) [Албул С.П., Бабушкин В.Д., Боревский Б.В., Веригин Н.Н., Володько И.Ф., Иванов В.Н., Керкис Е.Е., Кирюхин В.А., Климентов П.П., Кононов В.М., Коноплянцев А.А., Кругликов Н.М., Лехтимяки Э.В., Максимов В.М., Маршалов А.Ф., Матвеев Б.К., Матвеева Э.С., Новожилов В.Н., Огильви А.А., Однопозов В.Л., Онин Н.М., Остроумов Б.П., Падуков В.А., Плотников Н.И., Позин Э.П., Семенов С.М., Хохловкин Д.М., Язвин Л.С., Яковлев А.М. Справочное руководство гидрогеолога. Л.: Недра, 1979. T. 1.512 c.].

Albul S.P., Babushkin V.D., Borevsky B.V., Verigin N.N., Volod'ko I.F., Ivanov V.N., Kerkis E.E., Kiryukhin V.A., Klimentov P.P., Kononov V.M., Konoplyantsev A.A., Kruglikov N.M., Lekhtimyaki E.V., Maksimov V.M., Marshalov A.F., Matveev B.K., Matveeva E.S., Novozhylov V.N., Ogilvi A.A., Odnopozov V.L., Onin N.M., Ostroumov B.P., Padukov V.A., Plotnikov N.I., Pozin E.P., Semenov S.M., Khokhlovkin D.M., Yazvin L.S., Yakovlev A.M., 1979. Guidebook for 
Hydrogeologist. Nedra, Leningrad, Volume 2. 295 p. (in Russian) [Албул С.П., Бабушкин В.Д., Боревский Б.В., Веригин Н.Н., Володько И.Ф., Иванов В.Н., Керкис Е.Е., Кирюхин В.А., Климентов П.П., Кононов В.М., Коноплянцев А.А., Кругликов Н.М., Лехтимяки Э.В., Максимов В.М., Маршалов А.Ф., Матвеев Б.К., Матвеева Э.С., Новожилов В.Н., Огильви А.А., Однопозов В.Л., Онин Н.М., Остроумов Б.П., Падуков В.А., Плотников Н.И., Позин Э.П., Семенов С.М., Хохловкин Д.М., Язвин Л.С., Яковлев А.М. Справочное руководство гидрогеолога. Л.: Недра, 1979. T. 2. 295 c.].

Alexandrov V.K., 1990. Thrust and Overthrust Structures of the Pribaikalie. Nauka, Novosibirsk. 102 p. (in Russian) [Александров B.К. Надвиговые и шарьяжные структуры Прибайкалья. Новосибирск: Наука, 1990. 102 с.].

Bahroudi A., Koyi H.A., Talbot C.J., 2003. Effect of ductile and frictional decollements on style of extension. Journal of Structural Geology 25 (9), 1401-1423. http://dx.doi.org/10.1016/S0191-8141(02)00201-8.

Bashkuev Yu.B., Khaptanov V.B., Tsydypov Ch.Ts., Buyanova D.G., 1989. The Natural Electromagnetic Field in the Transbaikalie. Nauka, Moscow. 112 p. (in Russian) [Башкуев Ю.Б., Хаптанов В.Б., Цыдыпов Ч.Ц., Буянова Д.Г. Естественное электромагнитное поле в Забайкалье. М.: Наука, 1989. 112 с.].

Bastrakova N.V., 1985. The information content of water-helium surveys in consideration of the issues of groundwater formation. Razvedka i okhrana nedr 12, 42-46 (in Russian) [Бастракова Н.В. Информативность водно-гелиевой съемки при изучении вопросов формирования подземных вод // Разведка и охрана недр. 1985. № 12. С. 42-46].

Bastrakova N.V., 1990. The information content of water-helium surveys in hydrogeological studies of the platform areas. In: Methods of regional hydrogeological studies. VSEGINGEO, Moscow, p. 22-28 (in Russian) [Бастракова Н.В. Информативность водно-гелиевой съемки при гидрогеологическом изучении платформенных областей // Методы региональных гидрогеологических исследований. М.: ВСЕГИНГЕО, 1990. С. 22-28].

Bataleva E.A., 2005. The Deep Structure of the Major Fault Zones of the Western Part of the Kyrgyz Tien Shan and Modern Geodynamics (According to Magnetotelluric Sounding Data): Synopsis of PhD Thesis (Candidate degree in geology and mineralogy), Novosibirsk, 20 p. (in Russian) [Баталева Е.А. Глубинная структура крупнейших разломных зон западной части Киргизского Тянь-Шаня и современная геодинамика (по данным магнитотеллурических зондирований): Автореф. дис. ... канд. геол.-мин. наук. Новосибирск, 2005. 20 с.].

Becken M., Ritter O., Park S.K., Bedrosian P.A., Weckmann U., Weber M., 2008. A deep crustal fluid channel into the San Andreas Fault system near Parkfield, California. Geophysical Journal International 173 (2), 718-732. http://dx.doi.org/ 10.1111/j.1365-246X.2008.03754.x.

Ben-Zion Y., Sammis C.G., 2003. Characterization of fault zones. Pure and Applied Geophysics 160 (3-4), 677-715. http:// dx.doi.org/10.1007/PL00012554.

Berdichevskii M.N., Borisova V.P., Golubtsova N.S., Ingerov A.I., Konovalov Yu.F., Kulikov A.V., Solodilov L.N., Chernyavskii G.A., Shpak I.P., 1996. Interpretation of magnetotelluric soundings in the Lesser Caucasus. Izvestiya, Physics of the Solid Earth 32 (4), 365-370.

Berdichevsky M.N., Vanyan L.L., Koshurnikov A.V., 1999. Magnetotelluric sounding in the Baikal rift zone. Izvestiya, Physics of the Solid Earth 35 (10), 793-814.

Bigalke J., Grabner E.W., 1997. The Geobattery model - a contribution to large scale electrochemistry. Electrochimica Acta 42 (23-24), 3443-3452. http://dx.doi.org/10.1016/S0013-4686(97)00053-4.

Bokun A.N., 1985. The development and character of fractures in flexure-type bending models. In: Experimental tectonics in theoretical and applied geology. Nauka, Moscow, p. 230-237 (in Russian) [Бокун А.Н. Развитие и характер трещин в моделях флексурообразного изгиба // Экспериментальная тектоника в теоретической и практической геологии. М.: Наука, 1985. С. 230-237].

Bukharov A.A., Fialkov V.A., 1996. The Geological Structure of the Bottom of Lake Baikal. Nauka, Novosibirsk, 117 p. (in Russian) [Бухаров А.А., Фиалков В.А. Геологическое строение дна Байкала. Новосибирск: Наука, 1996. 117 с.].

Bulgatov A.N., Bulnaev K.B., Ochirov Ts.P., Turunkhaev V.I., 1978. Tectonic Faults of the Transbaikalia. Nauka, Novosibirsk, 112 p. (in Russian) [Булгатов А.Н., Булнаев К.Б., Очиров Ц.О., Турунхаев В.И. Тектонические разломы Забайкалья. Новосибирск: Наука, 1978. 112 с.].

Calais E., Vergnolle M., San'kov V., Lukhnev A., Miroshnitchenko A., Amarjargal S., Deverchere J., 2003. GPS measurements of crustal deformation in the Baikal-Mongolia area (1994-2002): Implications for current kinematics of Asia. Journal of Geophysical Research: Solid Earth 108 (B10). http://dx.doi.org/10.1029/2002JB002373.

Chen C.-C., Chi S.-C., Chen C.-S., Yang C.-H., 2007. Electrical structures of the source area of the 1999 Chi-Chi, Taiwan, earthquake: Spatial correlation between crustal conductors and aftershocks. Tectonophysics 443 (3-4), 280-288. http://dx.doi.org/10.1016/j.tecto.2007.01.018.

Cheremnykh A.V., 2003. The fault-block structure of the crust in the southern part of East Siberia and the tectonic activity of blocks // Vestnik Tomskogo Gosudarstvennogo Universiteta 3, 187-189 (in Russian) [Черемных А.В. Разломно-блоковое строение земной коры юга Восточной Сибири и тектоническая активность блоков // Вестник Томского государственного университета. 2003. № 3. С. 187-189].

Cheremnykh A.V., 2010. Internal structures of fault zones in the Priolkhonie and evolution of the state of stresses of the upper crust of the Baikal rift. Geodynamics \& Tectonophysics 1 (3), 273-284. http://dx.doi.org/10.5800/GT-2010-1-3-0021.

Cheremnykh A.V., Markovtseva O.V., 2007. Fracturing and the state of stresses of the Primorsky fault zone (Western Pribai- 
kalie). Izvestiya Sibirskogo otdeleniya, sektsii nauk o Zemle RAEN. Geologiya, poiski i razvedka rudnykh mestorozhdeniy 30 (4), 70-76 (in Russian) [Черемных А.В., Марковцева О.В. Трещиноватость и напряженное состояние в зоне Приморского сброса (Западное Прибайкалье) // Известия Сибирского отделения, секции наук о Земле РАEН. Геология, поиски и разведка рудных месторождений. 2007. Т. 30. № 4. С. 70-76].

Chernykh V.T., Astakhov N.E., 1981. Natural radioactive elements in rocks and waters of the western part of the IvolginoUda basin. In: Geochemical studies of rocks, minerals and waters in the Transbaikalia. Buryatian Division, Siberian Branch of the USSR Acad. Sci., Ulan-Ude, p. 33-44 (in Russian) [Черных B.T., Астахов Н.Е. Естественные радиоактивные элементы в породах и водах западной части Иволгино-Удинской впадины // Геохимические исследования горных пород, минералов и вод Забайкалья. Улан-Удэ: БФ СО АН СССР, 1981. С. 33-44].

Cloos E., 1968. Experimental analysis of Gulf Coast fracture patterns. American Association of Petroleum Geologists Bulletin 52 (3), 420-444.

Dahlin T., 2001. The development of electrical imaging techniques. Computers and Geosciences 27 (9), 1019-1029. http:// dx.doi.org/10.1016/S0098-3004(00)00160-6.

Delvaux D., Moyes R., Stapel G., Melnikov A., Ermikov V., 1995. Paleostress reconstruction and geodynamics of the Baikal region, Central Asia. Part I: Palaeozoic and Mesozoic pre-rift evolution. Tectonophysics 252 (1-4), 61-101. http://dx.doi. org/10.1016/0040-1951(95)00090-9.

Delvaux D., Moyes R., Stapel G., Petit C., Levi K., Miroshnitchenko A., Ruzhich V., San'kov V., 1997. Paleostress reconstruction and geodynamics of the Baikal region, Central Asia. Part II: Cenozoic rifting. Tectonophysics 282 (1-4), 1-38. http://dx.doi.org/10.1016/S0040-1951(97)00210-2.

Dombrovskaya Zh.V., 1973. The Paleogenic Weathering Crust of the Central Pribaikalie. Nauka, Moscow. 153 p. (in Russian) [Домбровская Ж.В. Палеогеновая кора выветривания Центрального Прибайкалья. М.: Наука, 1973. 153 c.].

Duchkov A.D., Lysak S.V., Golubev V.A., Dorofeeva R.P., Sokolova L.S., 1999. Heat flow and geothermal field of the Baikal region. Geologiya i geofizika 40 (3), 287-303 (in Russian) [Дучков А.Д., Лысак С.В., Голубев В.А., Дорофеева Р.П., Соколова Л.С. Тепловой поток и геотемпературное поле Байкальского региона // Геология и геофизика. 1999. T. 40. № 3. С. 287-303].

Epov M.I., Pospeeva E.V., Vitte L.V., 2012. Crust structure and composition in the southern Siberian craton (influence zone of Baikal rifting), from magnetotelluric data. Russian Geology and Geophysics 53 (3), 293-306. http://dx.doi.org/10.1016 /j.rgg.2012.02.006.

Fedorovsky V.S., 1997. Dome tectonics in the Caledonian collision system of Western Cisbaikalia. Geotectonics 31 (6), 483 497.

Florensov N.A., 1960.The Mesozoic and Cenozoic Basins of the Pribaikalie. Publishing House of the USSR Acad. Sci., Moscow-Leningrad, 257 p. (in Russian) [Флоренсов Н.A. Мезозойские и кайнозойские впадины Прибайкалья. М.Л.: Изд-во АН СССР, 1960. 257 с.].

Florensov N.A. (Ed.), 1977. The Role of Rifting in the Geological History of the Earth. Nauka, Novosibirsk, 224 p. (in Russian) [Роль рифтогенеза в геологической истории Земли / Под ред. Н.А. Флоренсова. Новосибирск: Наука, 1977. 224 c.].

Gatinsky Yu.G., Rundquist D.V., 2004. Geodynamics of Eurasia: Plate tectonics and block tectonics. Geotectonics 38 (1), $1-16$.

Gatinsky Yu.G., Rundquist D.V., Tyupkin Yu.S., 2005. Block structures and kinematics of Eastern and Central Asia from GPS data. Geotectonics 39 (5), 333-348.

Gatinsky Yu.G., Rundquist D.V., Tyupkin Yu.S., 2007. Block structures and kinematics of Western Eurasia according to GPS data. Geotectonics 41 (1), 26-37. http://dx.doi.org/10.1134/S0016852107010049.

Gibbs A.D., 1990. Linked fault families in basin formation. Journal of Structural Geology 12 (5-6), 795-803. http://dx.doi. org/10.1016/0191-8141(90)90090-L.

Glasko M.P., Rantsman E.Ya., 1995. The impact of the modern block structure of the crust of flat areas on safety of technical facilities. Izvestiya RAN. Seriya geograficheskaya 3, 76-80 (in Russian) [Гласко М.П., Ранцман Е.Я. Влияние современной блоковой структуры земной коры равнинных территорий на сохранность технических объектов // Известия РАН. Серия географическая. 1995. № 3. С. 76-80].

Glinsky B.M., Dikhter I.Ya., Zeigarnik V.A., El'tsov I.N., Ivanov V.M., Mandelbaum M.M., Morozova G.M., Shamal' A.I., 1991. The complex of methodological and instrumental methods and results of electromagnetic soundings with a powerful energy source at the Baikal prognostic polygon. Doklady AN SSSR 308 (1), 59-62 (in Russian) [Глинский Б.М., Дихтер И.Я., Зейгарник В.А., Ельцов И.Н., Иванов В.М., Мандельбаум М.М., Морозова Г.М., Шамаль А.И. Комплекс методических, аппаратурных средств и результаты электромагнитных зондирований с мощным энергоисточником на Байкальском прогностическом полигоне // Доклады АН СССР. 1991. Т. 308. № 1. С. 59-62].

Gol'din S.V., 2002. Destruction of the lithosphere and physical mesomechanics. Fizicheskaya Mezomekhanika 5 (5), 5-22 (in Russian) [Гольдин С.В. Деструкция литосферы и физическая мезомеханика // Физическая мезомеханика. 2002. Т. 5. № 5. C. 5-22].

Gol'din S.V., Suvorov V.D., Makarov P.V., Stefanov Yu.P., 2006. An instability gravity model for the structure and stress- 
strain state of lithosphere in the Baikal rift. Russian Geology and Geophysics 47 (10), 1079-1090.

Golubev V.A., 1988. The hydrothermal flow and the thermal field of the Baikal rift zone // Doklady AN SSSR 302 (3), 575578 (in Russian) [Голубев B.А. Гидротермальный сток и тепловое поле Байкальской рифтовой зоны // Доклады АН CССР. 1988. T. 302. № 3. С. 575-578].

Golubev V.A., 2007. Conductive and convective heat loss in the Baikal rift zone. GEO Branch, Publishing House of SB RAS, Novosibirsk, 222 p. (in Russian) [Голубев B.А. Кондуктивный и конвективный вынос тепла в Байкальской рифтовой зоне. Новосибирск: Изд-во СО РАН, Филиал «ГЕО», 2007. 222 с.].

Gornostaev V.P., 1972. About the deep geoelectrical model of the Pribaikalie. Geologiya i Geofizika 6, 98-102 (in Russian) [Горностаев В.П. О глубинной геоэлектрической модели Прибайкалья // Геология и геофизика. 1972. № 6. С. 98102].

Gornostaev V.P., 1979. Magnetotelluric surveys of the Lake Baikal basin. Fizika Zemli 6, 99-103 (in Russian) [Горностаев В.П. Магнитотеллурические исследования впадины оз. Байкал // Физика Земли. 1979. № 6. С. 99-103].

Gornostaev V.P., Mikhalevsky V.I., Pospeev V.I., 1970. The deep magnetotelluric sounding in the southern part of the Siberian platform and the Baikal rift zone. Geologiya i Geofizika 4, 111-118 (in Russian) [Горностаев В.П., Михалевский В.И., Поспеев В.И. Глубинные магнитотеллурические зондирования на юге Сибирской платформы и в зоне Байкальского рифта // Геология и геофизика. 1970. № 4. С. 111-118].

Grigoriev A.S., Volovich I.M., Mikhailova A.V., Rebetsky Yu.L., Shakhmuradova Z.E., 1987. The study of the state of stresses, kinematics and development of discontinuities of the sedimentary cover above active faults of the foundation (combination of mathematical simulation and physical modelling under plane-strain conditions). In: Fields of stresses and deformation in the Earth's crust. Nauka, Moscow, p. 5-41 (in Russian) [Григорьев А.С., Волович И.М., Михайлова А.В., Ребецкий Ю.Л., Шахмурадова З.Е. Исследование напряженного состояния, кинематики и развития нарушений сплошности осадочного чехла над активными разломами фундамента (при сочетании математическго и физического моделирования в условиях плоской деформации) // Поля напряжений и деформаций в земной коре. М.: Наука, 1987. С. 5-41].

Gufeld I.L., Matveeva M.I., Novoselov O.N., 2011. Why we cannot predict strong earthquakes in the Earth's crust. Geodynamics \& Tectonophysics 2 (4), 378-415. http://dx.doi.org/10.5800/GT-2011-2-4-0051.

Gutmanis J.C., Lanyon G.W., Wynn T.J., Watson C.R., 1998. Fluid flow in faults: a study of fault hydrogeology in Triassic sandstone and Ordovician volcaniclastic rocks at Sellafield, north-west England. Proceeding of the Yorkshire Geological Society 52 (2), 159-175. http://dx.doi.org/10.1144/pygs.52.2.159.

Gzovsky M.V., 1963. Main Issues of Tectonophysics and Tectonics of the Baydzhansayskoe Anticlinorium. Publishing House of the USSR Academy of Sciences, Moscow, Parts III-IV, 544 p. (in Russian) [Гзовский М.В. Основные вопросы тектонофизики и тектоника Байджансайского антиклинория. М.: Изд-во АН СССР, 1963. Ч. III-IV. 544 с.].

Hoffmann-Rothe A., Ritter O., Janssen C., 2004. Correlation of electrical conductivity and structural damage at a major strike-slip fault in northern Chile. Journal of Geophysical Research: Solid Earth 109 (B10). http://dx.doi.org/10.1029/ 2004JB003030.

Hutchinson D.R., Golmshtok A.Ya., Zonenshain L.P., Moore T.C., Scholz C.A., Klitgord K.D., 1992. Depositional and tectonic framework of the rift basins of Lake Baikal from multichannel seismic data. Geology 20 (7), 589-592. http:// dx.doi.org/10.1130/0091-7613(1992)020<0589:DATFOT>2.3.CO;2.

Isaev V.P., 2001. About gas paleo-volcanism at Baikal. Geologiya nefti i gaza 5, 45-50 (in Russian) [Исаев В.П. О газовом палеовулканизме на Байкале // Геология нефти и газа. 2001. № 5. С. 45-50].

Jacobi R.D., 2002. Basement faults and seismicity in the Appalachian Basin of New York State. Tectonophysics 353 (1-4), 75-113. http://dx.doi.org/10.1016/S0040-1951(02)00278-0.

Janssen C., Hoffmann-Rothe A., Tauber S., Wilke H., 2002. Internal structure of the Precordilleran fault system (Chile) insights from structural and geophysical observations. Journal of Structural Geology 24 (1), 123-143. http://dx.doi.org/ 10.1016/S0191-8141(01)00053-0.

Kashik S.A. (Ed.), 1978. Dynamics of the Earth's Crust in Eastern Siberia. Nauka, Novosibirsk, 127 p. (in Russian) [Динамика земной коры Восточной Сибири / Отв. ред. С.А. Кашик. Новосибирск: Наука, 1978. 127 с.].

Kaz'min V.G., Gol'mshtok A.Ya., Klitgord K., Moore T., Hutchinson D., Scholz K., Weber I., 1995. The structure and development of the Academic ridge area according to seismic and submarine survey data (Baikal rift). Geologiya i Geofizika 36 (10), 164-176 (in Russian) [Казьмин В.Г., Гольмшток А.Я., Клитгорд К., Мур Т., Хатчинсон Д., Шольц К., Вебер И. Строение и развитие района Академического хребта по данным сейсмических и подводных исследований (Байкальский рифт) // Геология и геофизика. 1995. Т. 36. № 10. С. 164-176].

Khain V.E., 1984. International Tectonic Map of the World (Scale 1:15000000). Mingeo, Moscow.

Khaustov A.P., Grabar A.V., 1999. Ground waters of block structures and methods for their identification in crystalline massifs. Izvestiya vuzov, Geologiya i Razvedka 3, 85-96 (in Russian) [Хаустов А.П., Грабарь А.В. Подземные воды блоковых структур и методы их идентификации в кристаллических массивах // Известия вузов, Геология и разведка. 1999. № 3. С. 85-96].

Kissin I.G., 1996. Fluid saturation, electrical conductivity, and seismicity of the crust. Izvestiya, Physics of the Solid Earth 32 (4), 295-303. 
Kissin I.G., Ruzaikin A.I., 2000. Earthquake sources in the field of geoelectric inhomogeneities in the crust of the Baikal rift zone. Izvestiya, Physics of the Solid Earth 36 (7), 589-596.

Klerkx J., De Batist M., Poort J., Hus R., Van Rensbergen P., Khlystov O., Granin N., 2006. Tectonically controlled methane escape in Lake Baikal. In: Lombardi S., Altunina L.K., Beaubien S.E. (Eds.), Advances in the geological storage of carbon dioxide. Springer, Netherlands, Part III, p. 203-219. http://dx.doi.org/10.1007/1-4020-4471-2_17.

Klyuchevskii A.V., Zuev F.L., 2011. Fractal assessments of seismic process in the Baikal region lithosphere. Litosfera 1, 143149 (in Russian) [Ключевский А.В., Зуев Ф.Л. Фрактальные оценки сейсмического процесса в литосфере Байкальского региона // Литосфера. 2011. № 1. С. 143-149].

Kocharyan G.G., Kishkina S.B., Ostapchuk A.A., 2010. Seismic picture of a fault zone. What can be gained from the analysis of fine patterns of spatial distribution of weak earthquake centers? Geodynamics \& Tectonophysics 1 (4), 419-440. http://dx.doi.org/10.5800/GT-2010-1-4-0027.

Komarov V.A., 1994. Geoelectrochemistry. Textbook. St. Petersburg State University, St. Petersburg, 136 p. (in Russian) [Комаров В.А. Геоэлектрохимия / Учебное пособие. СПб.: СПбГУ, 1994. 136 с.].

Kondratiev V.N., Kulyukin A.M., Ponomarev V.S., Romashov A.N., 1985. The study of a two-layer model of the Earth's crust under conditions of biaxial stretching of the lower layer // Izvestiya AN SSSR. Fizika Zemli 3, 17-28 (in Russian) [Кондратьев В.Н., Кулюкин А.М., Пономарев В.С., Ромашов А.Н. Исследование двухслойной модели земной коры при двухосном растяжении нижнего слоя // Известия АН СССР. Физика Земли. 1985. № 3. С. 17-28].

Kostyuchenko V.N., Kocharyan G.G., Pavlov D.V., 2002. Deformation characteristics of interblock sections of various scales. Fizicheskaya mezomekhanika 5 (2), 23-42 (in Russian) [Костюченко В.Н., Кочарян Г.Г., Павлов Д.В. Деформационные характеристики межблоковых промежутков различного масштаба // Физическая мезомеханика. 2002. Т. 5. № 5. C. 23-42].

Koval P.V., Udodov Yu.N., San'kov V.A., Yasenovskii A.A., Andrulaitis L.D., 2006. Geochemical activity of faults in the Baikal rift zone (mercury, radon, and thoron). Doklady Earth Sciences 409 (6), 912-915. http://dx.doi.org/10.1134/S1028334 X06060171.

Kozhevnikov N.O., 1998. Structural peculiarities of Priolkhonye by the electrical survey data (West Transbaikalia). Geologiya i Geofizika 39 (2), 271-276 (in Russian) [Кожевников Н.O. Некоторые особенности структуры Приольхонья по данным электроразведки (Западное Прибайкалье) // Геология и геофизика. 1998. Т. 39. № 2. С. 271-276].

Kozhevnikov N.O., Bigalke J., Kozhevnikov O.K., 2004. Geoelectrical surveys in the Olkhon region; methods, results, and tectonic implications. Russian Geology and Geophysics 45 (2), 235-246.

Kozhevnikov N.O., Tezkan B., 1998. The main structure and tectonic features of the Chernorud-Mukhor site on the western shore of Lake Baikal from TEM and SP measurements. Journal of Applied Geophysics 39 (4), 237-250. http://dx.doi.org/ 10.1016/S0926-9851(98)00005-6.

Krasny L.I., 1984. The global divisibility of the lithosphere under the geo-blocks concept. Sovetskaya geologiya 7, 17-32 (in Russian) [Красный Л.И. Глобальная делимость литосферы в свете геоблоковой концепции // Советская геология. 1984. № 7. С. 17-32].

Krasny L.I., 2003. The Evolution of Tectonic Ideas from the Middle of the 19th Century to the Present. Ocean Geology Research Institute, St. Petersburg. 28 p. (in Russian) [Красный Л.И. Эволюция тектонических идей от середины ХIX столетия до современности. СПб.: ВНИИ Океангеология, 2003. 28 с.].

Krylov S.V., Mandelbaum M.M., Mishen'kin B.P., Mishen'kina Z.R., Petrik G.V., Seleznev V.S., 1981. The Interiors of Baikal (from Seismic Data). Nauka, Novosibirsk, 105 p. (in Russian) [Крылов С.В., Мандельбаум М.М., Мишенькин Б.П., Мишенькина З.Р., Петрик Г.В., Селезнев В.С. Недра Байкала (по сейсмическим данным). Новосибирск: Наука, 1981. 105 c.].

Kuklei L.N., 1985. The Precambrian Western Pribaikalie. IPE RAS, Moscow, 189 p. (in Russian) [Куклей Л.Н. Докембрий Западного Прибайкалья. Москва: ИФЗ РАН, 1985. 189 с.].

Kurlenya M.V., Seryakov V.M., Eremenko A.A., 2005. Technogenic Geomechanical Stress Fields. Nauka, Novosibirsk, 264 p. (in Russian) [Курленя M.В., Серяков В.M., Еременко А.А. Техногенные геомеханические поля напряжений. Новосибирск: Наука, 2005. 264 с.].

Lesne O., Calais E., Deverchere J., 1998. Finite element modeling of crustal deformation in the Baikal rift zone: new insights into the active-passive rifting debate. Tectonophysics 289 (4), 327-340. http://dx.doi.org/10.1016/S0040-1951(98)000043.

Lesne O., Calais E., Deverchere J., Chery J., Hassani R., 2000. Dynamics of intracontinental extension in the northern Baikal rift zone, Siberia, using lithospheric-scale numerical models. Journal of Geophysical Research: Solid Earth 105 (B9), 21727-21744. http://dx.doi.org/10.1029/2000JB900139.

Levi K.G., 1980. Relative displacements of plates in the Baikal rift zone. Geologiya i Geofizika 5, 9-15 (in Russian) [Лeвu К.Г. Относительное перемещение плит в Байкальской рифтовой зоне // Геология и геофизика. 1980. № 5. С. 9-15].

Levi K.G., Arzhannikova A.V., Buddo V.Yu., Kirillov P.G., Lukhnev A.V., Miroshnichenko A.I., Ruzhich V.V., San'kov V.A., 1997a. Recent geodynamics of the Baikal rift. Razvedka i okhrana nedr 1, 10-20 (in Russian) [Леви К.Г., Аржанникова А.В., Буддо В.Ю., Кириллов П.Г., Лухнев А.В., Мирошниченко А.И., Ружич В.В., Саньков В.А. Современная геодинамика Байкальского рифта // Разведка и охрана недр. 1997. № 1. С. 10-20]. 
Levi K.G., Babushkin S.M., Badardinov A.A., Buddo V.Yu., Larkin G.V., Miroshnichenko A.I., San'kov V.A., Ruzhich V.V., Wong H.K., Delvaux D., Coleman S., 1995. Active tectonics of Lake Baikal. Geologiya i Geofizika 36 (10), 154-163 (in Russian) [Леви К.Г., Бабушкин С.М., Бадардинов А.А., Буддо В.Ю., Ларкин Г.В., Мирошниченко А.И., Саньков B.А., Ружич В.В., Вонг Х.К., Дельво Д., Колман С. Активная тектоника Байкала // Геология и геофизика. 1995. Т. 36. № 10. C. 154-163].

Levi K.G., Miroshnitchenko A.I., San'kov V.A., Babushkin S.M., Larkin G.V., Badardinov A.A., Wong H.K., Colman S., Delvaux D., 1997b. Active faults of the Baikal depression. Bulletin des Centres de Recherches Elf Exploration Production 21 (2), 399-434.

Lobatskaya R.M., 1987. Structural Zonation of Faults. Nedra, Moscow, 183 p. (in Russian) [Лобацкая Р.М. Структурная зональность разломов. М.: Недра, 1987. 183 с.].

Logachev N.A. (Ed.), 1984. Geology and Seismicity of the BAM Zone. Volume 3, Neotectonics. Nauka, Novosibirsk, 207 p. (in Russian) [Геология и сейсмичность зоны БАМ. Том 3. Неотектоника / Под ред. Н.А. Логачева. Новосибирск: Наука, 1984. 207 с.].

Logachev N.A. (Ed.), 1991. Faulting in the Lithosphere. Shear Zones. Nauka, Novosibirsk, 262 p. (in Russian) [Разломообразование в литосфере. Зоны сдвига / Под ред. Н.А. Логачева. Новосибирск: Наука, 1991. 262 с.].

Logachev N.A. (Ed.), 1992. Faulting in the Lithosphere. Extension Zones. Nauka, Novosibirsk, 222 p. (in Russian) [Разломообразование в литосфере. Зоны растяжения / Под ред. Н.А. Логачева. Новосибирск: Наука, 1992. 222 с.].

Logachev N.A. (Ed.), 1994. Faulting in the Lithosphere. Compression Zones. Nauka, Novosibirsk, 264 p. (in Russian) [Pa3ломообразование в литосфере. Зоны сжатия / Под ред. Н.А. Логачева. Новосибирск: Наука, 1994. 264 с.].

Logachev N.A., 2003. History and Geodynamics of the Baikal Rift. Russian Geology and Geophysics 44 (5), 373-387.

Logachev N.A., Florensov N.A., 1977. The Baikal system of rift basins. In: The role of rifting in the geological history of the Earth. Nauka, Novosibirsk, p. 19-29 (in Russian) [Логачев Н.А., Флоренсов Н.А. Байкальская система рифтовых долин. Роль рифтогенеза в геологической истории Земли. Новосибирск: Наука, 1977. С. 19-29].

Logatchev N.A., Lomonosova T.K., Klimanova V.M., 1964. The Cenozoic Sediments of the Irkutsk Amphitheater. Nauka, Moscow, 196 p. (in Russian) [Логачев Н.А., Ломоносова Т.К., Климанова В.М. Кайнозойские отложения Иркутского амфитеатра. М.: Наука, 1964. 196 с.].

Logatchev N.A., Zorin Yu.A., 1992. Baikal rift zone: structure and geodynamics. Tectonophysics 208 (1-3), 273-286. http:// dx.doi.org/10.1016/0040-1951(92)90349-B.

Lunina O.V., Gladkov A.S., Cheremnykh A.V., 2002. Fracturing in the Primorsky Fault Zone (Baikal Rift System). Russian Geology and Geophysics 43 (5), 446-455.

Lunina O.V., Gladkov A.S., Nevedrova N.N., 2009. The Baikal Rift Basins: Its Tectonic Structure and Development History. GEO Branch, Publishing House of SB RAS, Novosibirsk, 316 p. (in Russian) [Лунина О.В., Гладков, А.С., Неведрова Н.Н. Рифтовые впадины Прибайкалья: тектоническое строение и история развития. Новосибирск: Изд-во СО РАН. Филиал «ГЕО», 2009. 316 с.].

Lysak S.V., 1988. Heat Flow of Continental Rift Zones. Nauka, Novosibirsk, 200 p. (in Russian) [Лысак С.В. Тепловой поток континентальных рифтовых зон. Новосибирск: Наука, 1988. 200 с.].

Maercklin N., Bedrosian P.A., Haberland C., Ritter O., Ryberg T., Weber M., Weckmann U., 2005. Characterizing a large shear-zone with seismic and magnetotelluric methods: The case of the Dead Sea Transform. Geophysical Research Letters 32 (15), L15303. http://dx.doi.org/10.1029/2005GL022724.

Makarov P.V., 2007. Evolutionary nature of structure formation in lithospheric material: universal principle for fractality of solids. Russian Geology and Geophysics 48 (7), 558-574. http://dx.doi.org/10.1016/j.rgg.2007.06.003.

Maslov N.N., Kotov M.F., 1971. Engineering Geology. Construction Publishing House, Moscow, 341 p. (in Russian) [Macлов Н.Н., Котов М.Ф. Инженерная геология. М.: Издательство литературы по строительству, 1971. 341 с.].

Mats V.D., 1993. The structure and development of the Baikal rift depression. Earth-Science Reviews 34 (2), 81-118. http:// dx.doi.org/10.1016/0012-8252(93)90028-6.

Mats V.D., Ufimtsev G.F., Mandelbaum M.M., Alakshin A.M., Pospeev A.V., Shimaraev M.N., Khlystov O.M., 2001. The Cenozoic Baikal Rift Basin: Its Structure and Geological History. Publishing House of SB RAS, Geo Branch, Novosibirsk, 252 p. (in Russian) [Мац В.Д., Уфимцев Г.Ф., Мандельбаум М.М., Алакшин А.М., Поспеев А.В., Шимараев M.Н., Хлыстов О.М. Кайнозой Байкальской рифтовой впадины: строение и геологическая история. Новосибирск: Изд-во СО РАН. Филиал «ГЕО», 2001. 252 с.].

Mazukabzov A.M., Sizykh V.I., 1987. About the nappe-scaly structure of the Western Pribaikalie. Geotektonika 3, 87-90 (in Russian) [Мазукабзов А.M., Сизых В.И. О покровно-чешуйчатом строении Западного Прибайкалья // Геотектоника. 1987. № 3. С. 87-90].

Mazukabzov A.M., Sklyarov E.V., Donskaya T.V., Gladkochub D.P., Fedorovsky V.S., 2011. Metamorphic core complexes of the Transbaikalia: review. Geodynamics \& Tectonophysics 2 (2), 95-125. http://dx.doi.org/10.5800/GT-2011-2-2-0036.

McCalpin J.P. (Ed.), 1996. Paleoseismology. Academic press, San Diego, 585 p.

McClay K.R., Dooley T., Hollings P., Keller J., Thompson L, White M., 1992. Analogue modelling: Fault dynamics project 
report. 1992. N. 3. Part II. P. 15-36.

Melnikov A.I., Mazukabzov A.M., Sklyarov E.V., Vasiliev E.P., 1994. Baikal rift basement: structure and tectonic evolution. Bulletin des Centres Recherches Exploration Production elf Aquitaine 18 (1), 99-122.

Mel'nikova V.I., Radziminovich N.A., 1998. Mechanisms of action of earthquake foci in the Baikal region over the period 1991-1996. Geologiya i Geofizika 39 (11), 1598-1607.

Mishra D.C., 2011. A unified model of Neoarchean-Proterozoic convergence and rifting of Indian cratons: geophysical constraints. International Journal of Geosciences 2 (04), 610-630. http://dx.doi.org/10.4236/ijg.2011.24063.

Moore T.C., Jr., Klitgord K.D., Golmshtok A. J., Weber E., 1997. Sedimentation and subsidence patterns in the central and north basins of Lake Baikal from seismic stratigraphy. Geological Society of America Bulletin 109 (6), 746-766. http://dx.doi.org/10.1130/0016-7606(1997)109<0746:SASPIT>2.3.CO;2.

Mordvinova V.V., Deschamps A., Dugarmaa T., Deverchére J., Ulziibat M., Sankov V.A., Artem'ev A.A., Perrot J., 2007. Velocity Structure of the Lithosphere on the 2003 Mongolian-Baikal transect from SV waves. Izvestiya, Physics of the Solid Earth 43 (2), 119-129. http://dx.doi.org/10.1134/S1069351307020036.

Moroz Yu.F., Moroz T.A., 2012. Deep geoelectric section of the Baikal rift. Vestnik KRAUNTs, Nauki o Zemle 2 (20), 114126 (in Russian) [Мороз Ю.Ф., Мороз Т.А. Глубинный геоэлектрический разрез Байкальского рифта // Вестник КРАУНЦ, Науки о Земле. 2012. № 2. С. 114-126].

Morozova G.M., Dashevsky Ya.A., Nevedrova N.N., Grekhov I.N., 1999. The depth distribution of electric conductivity and the field of crustal stresses of the Baikal prognostic polygon. Geologiya i Geofizika 40 (3), 332-345 (in Russian) [Mopoзова Г.М., Дашевский Ю.А., Неведрова Н.Н., Грехов И.Н. Глубинное распределение электропроводности и поле напряжений в земной коре Байкальского прогностического полигона // Геология и геофизика. 1999. Т. 40 . № 3. C. 332-345].

Morozova G.M., Manstein A.K., El'tsov I.N., Nevedrova N.N., 1998. Deep electromagnetic sounding surveys with a controlled source in the Baikal rift zone. In: Geophysical methods of the Earth's Crust studies. Publishing House of SIC UIGGM, SB RAS, Novosibirsk, p. 57-62 (in Russian) [Морозова Г.М., Манштейн А.К., Ельцов И.Н., Неведрова Н.Н. Глубинные электромагнитные зондирования с контролируемым источником в Байкальской рифтовой зоне // Геофизические методы изучения земной коры. Новосибирск: Изд-во НИЦ ОИГГМ СО РАН, 1998. С. 57-62].

Neubauer F., Lips A., Kouzmanov K., Lexa J., Ivăşcanu P., 2005. 1: Subduction, slab detachment and mineralization: The Neogene in the Apuseni Mountains and Carpathians. Ore Geology Reviews 27 (1-4), 13-44. http://dx.doi.org/10.1016/ j.oregeorev.2005.07.002.

Nikolaev P.N., 1992. The Method of Tectono-Dynamic Analysis. Nedra, Moscow, 263 p. (in Russian) [Николаев П.Н. Mетодика тектоно-динамического анализа. М.: Недра, 1992. 263 с.].

Ochirov Ts.O., 1976. Block Tectonics of Transbaikalia. Nauka, Novosibirsk, 199 p. (in Russian) [Очиров Ц.О. Блоковая тектоника Забайкалья. Новосибирск: Наука, 1976. 199 с.].

Palacky G.J., 1989. Resistivity characteristics of geologic targets. In: M.N. Nabighian (Ed.), Electromagnetic methods in applied geophysics Theory: Tulsa, Okla. Society of Exploration Geophysicist, Vol. 1, p. 53-130.

Parfenov V.D., 1984. To the method of tectonophysical analysis of geological structures. Geotektonika 1, 60-72 (in Russian) [Парфенов В.Д. К методике тектонофизического анализа геологических структур // Геотектоника. 1984. № 1. C. 60-72].

Park R.G., 1997. Foundations of structural geology. Chapman \& Hall, London, 202 p.

Park S.K., Wernicke B., 2003. Electrical conductivity images of Quaternary faults and Tertiary detachment in the California Basin and Range. Tectonics 22 (4), 1030. http://dx.doi.org/10.1029/2001TC001324.

Pavlovsky E.V. (Ed.), 1969. Geology of the Pribaikalie. IEC SB AS USSR, Irkutsk, 127 p. (in Russian) [Геология Прибайкалья / Под ред. Е.В. Павловского. Иркутск: ИЗК СО АН СССР, 1969. 127 с.].

Perevoznikov D.D., 1999. Geomorphology of the Transition Zone from the Baikal Rift to the Siberian Platform: Synopsis of PhD Thesis (Candidate degree in geography), Irkutsk, 18 p. (in Russian) [Перевозников Д.Д. Геоморфология зоны перехода от Байкальского рифта к сибирской платформе: Автореф. дис. ... канд. геогр. наук. Иркутск, 1999. 18 с.].

Petit C., Deverchere J., 2006. Structure and evolution of the Baikal rift: A synthesis. Geochemistry, Geophysics, Geosystems 7 (11), Q11016. http://dx.doi.org/10.1029/2006GC001265.

Petit C., Deverchere J., Houdry-Lemont F., Sankov V., Melnikova V., Delvaux D., 1996. Present-day stress field changes along the Baikal rift and tectonic implications. Tectonics 15 (6), 1171-1191. http://dx.doi.org/10.1029/96TC00624.

Pinneker E.V., Pisarsky B.I., Lomonosov I.S., Koldysheva R.Ya., Didenko A.A., Sherman S.I., 1968. Hydrogeology of the Baikal region. Nauka, Moscow, 170 p. (in Russian) [Пиннекер Е.В., Писарский Б.И., Ломоносов И.С., Колдышева Р.Я., Диденко А.А., Шерман С.И. Гидрогеология Прибайкалья. М.: Наука, 1968. 170 с.].

Pinneker E.V., Popov A.M., Shpynev E.B., 1998. The depth of surface water penetration into the Earth's crust: Evidence from the Baikal Region. Doklady Earth Sciences 359 (3), 396-399.

Pleshanov S.P., Chernov Ya.A., 1968. About the role of faults in the geological structure of the Priolkhonie. Trudy Irkutskogo Politekhnicheskogo Instituta 42, 22-27 (in Russian) [Плешанов С.П., Чернов Ю.А. О роли разрывных нарушений в 
геологической структуре Приольхонья // Труды Иркутского политехнического института. 1968. Вып. 42. C. 22-27].

Pleshanov S.P., Romazina A.A., 1981. Some issues of the kinematics of faulting in the central part of the Baikal rift. In: Problems of faul tectonics. Nauka, Novosibirsk, p. 129-141 (in Russian) [Плешанов С.П., Ромазина А.А. Некоторые вопросы кинематики развития разломов центральной части Байкальского рифта // Проблемы разломной тектоники. Новосибирск: Наука, 1981. С. 129-141].

Plyusnin A.M., Astakhov N.E., Peryazeva E.G., 2009. Radon in surface and ground waters of the Transbaikalie: conditions and regularities of dissolution. In: Radioactivity and radioactive elements in human environment. STT, Tomsk, p. 444448 (in Russian) [Плюснин A.M., Астахов Н.E., Перязева Е.Г. Радон в поверхностных и подземных водах Забайкалья: условия и закономерности растворения // Радиоактивность и радиоактивные элементы в среде обитания человека. Томск: STT, 2009. С. 444-448].

Polyansky O.P., 2002. Dynamic causes for the opening of the Baikal rift zone: a numerical modeling approach. Tectonophysics 351 (1-2), 91-117. http://dx.doi.org/10.1016/S0040-1951(02)00127-0.

Ponomarev V.S., Romashov A.N., Sukhotin A.P., Tsygankov S.S., 1995. Specific features of destruction of two-layer models used to model geological processes. Geologiya i Geofizika 36 (4), 116-121 (in Russian) [Пономарев В.С., Ромашов А.Н., Сухотин А.П., Цыганков С.С. Особенности разрушения двухслойных моделей при моделировании геологических процессов // Геология и геофизика. 1995. Т. 36. № 4. С. 116-121].

Popov A.M., 1987. About causes of high electrical conductivity of the Earth's crust. Geologiya i Geofizika 12, 56-65 (in Russian) [Попов А.M. О причинах повышенной электропроводности в земной коре // Геология и геофизика. 1987. № 12. C. 56-65].

Popov A.M., 1989. Results of deep magnetotelluric sounding in the Baikal region in view of other geophysical methods. Fizika Zemli 8, 31-37 (in Russian) [Попов A.M. Результаты глубинных магнитотеллурических зондирований в Прибайкалье в свете данных других геофизических методов // Физика Земли. 1989. № 8. С. 31-37].

Pospeev A.V., 1998. Geoelectrics of the Continental Tectonosphere: Synopsis of PhD Thesis (Doctor of Sciences degree in geology and mineralogy), Irkutsk Technical University, Irkutsk, 34 p. (in Russian) [Поспеев А.В. Геоэлектрика континентальной тектоносферы: Автореф. дис. ... докт. геол.-мин. наук. Иркутск: Иркутский технический университет, 1998. 34 с.].

Pospeev V.I., Mikhalevsky V.I., 1975. MTS surveys in the southern part of the Siberian platform and the Baikal rift zone. In: Studies of thermal and electromagnetic fields in the USSR. Nauka, Moscow, p. 121-127 (in Russian) [Посnеев В.И., Михалевский В.И. Исследования на юге Сибирской платформы и в Байкальской рифтовой зоне (методом МТЗ) // Исследования теплового и электромагнитного полей в СССР. М.: Наука, 1975. С. 121-127].

Pospeev V.I., Van'yan L.L., Gornostaev V.P., 1978. Deep electrical conductivity of the Baikal and Pacific rift zones. In: The All-Union Workshop on electromagnetic sounding. Moscow State University Publishing House, Moscow, p. 45-51 (in Russian) [Поспеев В.И., Ваньян Л.Л., Горностаев В.П. Глубинная электропроводность Байкальской и Тихоокеанской рифтовых зон // Всесоюзная школа-семинар по электромагнитным зондированиям. М.: Изд-во МГУ, 1978 C. 45-51]

Radziminovich N.A., 2010. Focal depths of earthquakes in the Baikal region: a review. Izvestiya, Physics of the Solid Earth 46 (3), 216-229. http://dx.doi.org/10.1134/S1069351310030043.

Rasskazov S.V., 1993. Magmatism of the Baikal rift system. Nauka, Novosibirsk, 288 p. (in Russian) [Рaсcказов C.B. Maгматизм Байкальской рифтовой системы. Новосибирск: Наука, 1993. 288 с.].

Rastsvetaev L.M., 1987. The paragenetic method of structural analysis of disjunctive tectonic faults. In: Problems of structural geology and physics of tectonic processes. GIN, the USSS Acad. Sci., Part 2, p. $173-235$ (in Russian) [Pacцветаев Л.M. Парагенетический метод структурного анализа дизъюнктивных тектонических нарушений // Проблемы структурной геологии и физики тектонических процессов. М.: ГИН АН СССР, 1987. Ч. 2. С. 173-235].

Rezanov I.N., Tat'kov G.I., Kolomiets V.L., Nefediev M.A., Chebakov G.I., 2004. The regional stress field and seismically active tectonics of the Ust-Selenga basin. In: The evolution of tectonic processes in the Earth's history. GEO Branch, Publishing House of SB RAS, Novosibirsk, Volume 2, p. 106-109 (in Russian) [Резанов И.Н., Татьков Г.И., Коломиец В.Л., Нефедьев М.А., Чебаков Г.И. Региональное поле напряжений и сейсмоактивная тектоника Усть-Селенгинской впадины // Эволюция тектонических процессов в истории Земли. Новосибирск: Изд-во СО РАН. Филиал «ГЕО», 2004. Т. 2. С. 106-109].

Rodionov V.N., Sizov I.A., Tsvetkov V.M., 1986. Fundamentals of Rock Mechanics. Nedra, Moscow, 301 p. (in Russian) [Poдионов В.Н., Сизов И.А., Цветков В.М. Основы геомеханики. М.: Недра, 1986. 301 с.].

Ruzhich V.V., 1997. Seismotectonic Destruction in the Crust of the Baikal Rift Zone. Publishing House of SB RAS, Novosibirsk, 144 p. (in Russian) [Ружич B.B. Сейсмотектоническая деструкция в земной коре Байкальской рифтовой зоны. Новосибирск: Изд-во СО РАН, 1997. 144 с.].

Sadovsky M.A., Bolkhovitinov L.G., Pisarenko V.F., 1987. Deformation of Geophysical Medium and Seismic Process. Nauka, Moscow, 100 p. (in Russian) [Садовский М.А., Болховитинов Л.Г., Писаренко В.Ф. Деформирование геофизической среды и сейсмический процесс. М.: Наука, 1987. 100 с.].

San'kov V.A., 1989. Fault Penetration Depths. Nauka, Novosibirsk, 136 p. (in Russian) [Саньков В.А. Глубины проникновения разломов. Новосибирск: Наука, 1989. 136 с.]. 
San'kov V.A., Lukhnev A.V., Miroshnichenko A.I., Ashurkov S.V., Byzov L.M., Dembelov M.G., Calais E., Deverchère J., 2009. Extension in the Baikal rift: present-day kinematics of passive rifting. Doklady Earth Sciences 425 (2), 205-209. http://dx.doi.org/10.1134/S1028334X09020056.

San'kov V.A., Miroshnitchenko A.I., Levi K.G., Lukhnev A.V., Melnikov A.I., Delvaux D., 1997. Cenozoic stress field evolution in the Baikal rift zone. Bulletin Centre de Recherches Exploration Production Elf Aquitaine 21 (2), 435-455.

San'kov V.A., Parfeevets A.V., 2006. The State of Crustral Stresses and Geodynamics of the South-Western Part of the Baikal Rift System. GEO Branch, Publishing House of SB RAS, Novosibirsk, 149 p. (in Russian) [Саньков В.А., Парфеевец A.B. Напряженное состояние земной коры и геодинамика юго-западной части Байкальской рифтовой системы. Новосибирск: Изд-во СО РАН. Филиал «ГЕО», 2006. 149 с.].

San'kov V.A., Parfeevets A.V., Arzhannikova A.V., Lukhnev A.A., Miroshnichenko A.I., Ashurkov S.V., Burchevskaya M.A., 2003. The stress-and-strain state of crustal stresses and the kinematics of active faults at the periphery of the Baikal rift (the Western Transbaikalie). In: The geodynamic evolution of the lithosphere of the Central Asian mobile belt (from ocean to continent). IEC SB RAS, Irkutsk, p. 214-218 (in Russian) [Саньков В.А., Парфеевец А.В., Аржанникова А.В., Лухнев А.А., Мирошниченко А.И., Ашурков С.В., Бурчевская М.А. Напряженно-деформированное состояние земной коры и кинематика активных разломов на периферии Байкальского рифта (Западное Забайкалье) // Геодинамическая эволюция литосферы Центрально-Азиатского подвижного пояса (от океана к континенту). Иркутск: ИЗК СО РАН, 2003. С. 214-218].

San'kov V.A., Parfeevets A.V., Lukhnev A.V., Miroshnichenko A.I., Ashurkov S.V., 2011. Late Cenozoic geodynamics and mechanical coupling of crustal and upper mantle deformations in the Mongolia-Siberia mobile region. Geotectonics 45 (5), 378-393. http://dx.doi.org/10.1134/S0016852111050049.

Schmid M., De Batist M., Granin N.G., Kapitanov V.A., McGinnis D.F., Mizandrontsev I.B., Obzhirov A.I., Wuest A., 2007. Sources and sinks of methane in Lake Baikal: A synthesis of measurements and modeling. Limnology and Oceanography 52 (5), 1824-1837. http://dx.doi.org/10.4319/lo.2007.52.5.1824.

Scholz C.A., Klitgord K.D., Hutchinson D.R., ten Brink U.S., Zonenshain L.P., Golmshtok A.Y., Moore T.C., 1993. Results of 1992 seismic reflection experiment in Lake Baikal. Eos, Transactions American Geophysical Union 74 (41), 465-470. http://dx.doi.org/10.1029/93EO00546.

Schreurs G., Buiter S.L.H., Boutelier D., 2006. Analogue benchmarks of shortening and extension experiments. In: Analogue and numerical modelling of crustal-scale processes. Geological Society, London, Special Publications 253, 1-27. http:// dx.doi.org/10.1144/GSL.SP.2006.253.01.01.

Schulz S.E., Evans J.P., 2000. Mesoscopic structure of the Punchbowl Fault, Southern California and the geologic and geophysical structure of active strike-slip faults. Journal of Structural Geology 22 (7), 913-930. http://dx.doi.org/10.1016/ S0191-8141(00)00019-5.

Semenov A.S., 1980. Electromagnetic Surveys by the Natural Electric Field Method. Nedra, Leningrad, 446 p. (in Russian) [Семенов А.С. Электроразведка методом естественного электрического поля. Л.: Недра, 1980. 446 с.].

Seminskii K.Zh., 2008. Hierarchy in the zone-block lithospheric structure of Central and Eastern Asia. Russian Geology and Geophysics 49 (10), 771-779. http://dx.doi.org/10.1016/j.rgg.2007.11.017.

Seminskii K.Zh., Radziminovich Ya.B., 2011. Cross-Sectional Sizes and Lateral Zonality of the Baikal Seismic Belt. Doklady Earth Sciences 438 (1), 645-648. http://dx.doi.org/10.1134/S1028334X11050084.

Seminsky K.Zh., 1994. Principles and stages of special mapping of the fault-block structure on the basis of fracturing studies. Geologiya i Geofizika 9, 112-130 (in Russian) [Семинский К.Ж. Принципы и этапы спецкартирования разломноблоковой структуры на основе изучения трещиноватости // Геология и геофизика. 1994. № 9. С. 112-130].

Seminsky K.Zh., 2001. Tectonophysical regularities of destruction of the lithosphere as exemplified by the Himalayan compresion zone // Tikhookeanskaya geologiya 20 (6), 17-30 (in Russian) [Семинский К.Ж. Тектонофизические закономерности деструкции литосферы на примере Гималайской зоны сжатия // Тихоокеанская геология. 2001. Т. 20. № 6. C. 17-30].

Seminsky K.Zh., 2003. The Internal Structure of Continental Fault Zones. Tectonophysical Aspect. GEO Branch, Publishing House of SB RAS, Novosibirsk, 242 p. (in Russian) [Семинский К.Ж. Внутренняя структура континентальных разломных зон. Тектонофизический аспект. Новосибирск: Изд-во СО РАН. Филиал «ГЕО», 2003. 242 с.].

Seminsky K.Zh., 2009. Major factors of the evolution of basins and faults in the Baikal rift zone: Tectonophysical analysis. Geotectonics 43 (6), 486-500. http://dx.doi.org/10.1134/S001685210906003X.

Seminsky K.Zh., 2012. Internal structure of fault zones: spatial and temporal evolution studies on clay models. Geodynamics \& Tectonophysics 3 (3), 183-194. http://dx.doi.org/10.5800/GT-2012-3-3-0070.

Seminsky K.Zh., Bobrov A.A., 2009. Radon activity of faults (western Baikal and southern Angara areas). Russian Geology and Geophysics 50 (8), 682-692. http://dx.doi.org/10.1016/j.rgg.2008.12.010.

Seminsky K.Zh., Bobrov A.A., 2012. Spatial and temporal variations of soil-radon activity in fault zones of the Pribaikalie (East Siberia, Russia). In: Li Z., Feng C. (Eds.), Handbook of Radon: Properties, Applications and Health. Nova Science Publisher, New York, Ch. 1, p. 1-36.

Seminsky K.Zh., Burzunova Yu.P., 2007. Interpretation of chaotic jointing near fault planes: a new approach. Russian Geology and Geophysics 48 (3), 257-266. http://dx.doi.org/10.1016/j.rgg.2007.02.009. 
Seminsky K.Zh., Cheremnykh A.V., 2011. Jointing patterns and stress tensors in Cenozoic sediments of the Baikal rift: development of the structural-genetic approach. Russian Geology and Geophysics 52 (3), 353-367. http://dx.doi.org/10.1016/ j.rgg.2011.02.008.

Seminsky K.Zh., Demberel S., 2013. The first estimations of soil-radon activity near faults in Central Mongolia. Radiation Measurements 49, 19-34. http://dx.doi.org/10.1016/j.radmeas.2012.12.013.

Seminsky K.Zh., Karabanov E.B., Kuz'min M.I., 2001. Faulting in Baikal bottom sediments (studies of drilling core BDP-98). Geologiya i geofizika 42 (1-2), 306-316.

Seminsky K.Zh., Kozhevnikov N.O., Cheremnykh A.V., Pospeeva E.V., Bobrov A.A., Olenchenko V.V., Tugarina M.A., Potapov V.V., Burzunova Yu.P., 2012. Interblock zones of the northwestern Baikal rift: results of geological and geophysical studies along the Bayandai Village - Cape Krestovskii profile. Russian Geology and Geophysics 53 (2), 194-208. http:// dx.doi.org/10.1016/j.rgg.2011.12.016.

Seminsky K.Zh., Tugarina M.A., 2011. Results of comprehensive studies of the underground hydrosphere within the western shoulder of the Baikal rift (as exemplified by the Bayandai - Krestovsky Cape site). Geodynamics \& Tectonophysics 2 (2), 126-144. http://dx.doi.org/10.5800/GT-2011-2-2-0037.

Shebalin P., Soloviev A., Le Mouel J.-L., 2002. Scaling organization in the dynamics of blocks-and-faults systems. Physics of the Earth and Planetary Interiors 131 (2), 141-153. http://dx.doi.org/10.1016/S0031-9201(02)00033-X.

Sherman S.I., 1977. Physical Laws of Crustal Faults. Nauka, Novosibirsk, 102 p. (in Russian) [Шерман С.И. Физические закономерности развития разломов земной коры. Новосибирск: Наука, 1977. 102 с.].

Sherman S.I., 2012. Destruction of the lithosphere: Fault-block divisibility and its tectonophysical regularities. Geodynamics \& Tectonophysics 3 (4), 315-344. http://dx.doi.org/10.5800/GT-2012-3-4-0077.

Sherman S.I., Bornyakov S.A., Buddo V.Yu., 1983. Areas of Dynamic Influence of Faults (Modeling Results). Nauka, Novosibirsk, 112 p. (in Russian) [Шерман С.И., Борняков С.А., Буддо В.Ю. Области динамического влияния разломов (результаты моделирования). Новосибирск: Наука, 1983. 112 с.].

Sherman S.I., Dneprovsky Yu.I., 1989. Tectonic stress fields of the Baikal rift zone. Geotektonika 2, 101-112 (in Russian) [Шерман С.И., Днепровский Ю.И. Поля тектонических напряжений Байкальской рифтовой зоны // Геотектоника. 1989. № 2. С. 101-112].

Sherman S.I., Seminsky K.Zh., Cheremnykh A.V., 1999. Destructive zones and fault-block structures of the Central Asia. Tikhookeanskaya Geologiya 18 (2), 41-53 (in Russian) [Шерман С.И., Семинский К.Ж., Черемных А.В. Деструктивные зоны и разломно-блоковые структуры Центральной Азии // Тихоокеанская геология. 1999. Т. 18. № 2. С. 41-53].

Sherman S.I., Zlogodukhova O.G., 2011. Seismic belts and zones of the Earth: Formalization of notions, positions in the lithosphere and structural control. Geodynamics \& Tectonophysics 2 (1), 1-34. http://dx.doi.org/10.5800/GT-2011-2-10031.

Sklyarov E.V. (Ed.), 2005. Structural and tectonic correlation across the Central Asia orogenic collage: North-Eastern segment (Guidebook and abstract volume of the Siberian Workshop IGCP-480). IES SB RAS, Irkutsk, 291 p.

Sklyarov E.V., Fedorovskii V.S., Sklyarova O.A., Skovitina T.M., Danilova Yu.V., Orlova L.A., Ukhova N.N., 2007. Hydrothermal activity in the Baikal rift zone: recent hot springs and deposits of paleothermal waters. Doklady Earth Sciences 412 (2), 101-105. http://dx.doi.org/10.1134/S1028334X07010230.

Sklyarov E.V., Mazukabzov A.M., Melnikov A.I., 1997. Metamorphic Core Complexes of the Cordilleran Type. SIC UIGGM, Publishing House of SB RAS, Novosibirsk, 182 p. (in Russian) [Скляров Е.В., Мазукабзов А.М., Мельников А.И. Комплексы метаморфических ядер кордильерского типа. Новосибирск: НИЦ ОИГГМ СО РАН, 1997.182 с.].

Sklyarova O.A., Sklyarov E.V., Fedorovsky V.S., Sanina N.B., 2004. Mineral lakes in the Priolkhonie: issues of their genesis and evolution. Geografiya i prirodnye resursy 4, 44-49 (in Russian) [Склярова О.А., Скляров Е.В., Федоровский В.С., Санина Н.Б. Минеральные озера Приольхонья: вопросы генезиса и эволюции // География и природные ресурсы. 2004. № 4. C. 44-49].

Sobolev G.A., Asatryan Kh.O., 1990. The development of the hierarchy of fracturess during deformation of the higly plastic material. Doklady AN SSSR 315 (2), 345-348 (in Russian) [Соболев Г.А., Асатрян Х.О. Развитие иерархии разрывов при деформировании высокопластичного материала // Доклады АН СССР. 1990. Т. 315. № 2. С. 345-348].

Solonenko A.V., Solonenko N.V., Melnikova V.I., Shteiman E.A., 1997. The seismicity and earthquake focal mechanisms of the Baikal seismic zone. Bulletin des Centres Recherches Exploration Production Elf Aquitaine 21 (1), $207-231$.

Solonenko V.P. (Ed.), 1968. Seismotectonics and Seismicity of the Pribaikalie Rift System. Nauka, Moscow, 220 p. (in Russian) [Сейсмотектоника и сейсмичность рифтовой системы Прибайкалья / Под ред. В.П. Солоненко. М.: Наука, 1968. 220 c.].

Sorokina A.T., Sorokin A.P., Serov M.A., Popov A.A., 2011. Fault-block structures in the eastern margin of the Amur lithospheric plate, their seismicity, and fluid regimes. Russian Journal of Pacific Geology 5 (1), 13-25. http://dx.doi.org/ 10.1134/S1819714011010064.

Stepanov V.M., 1959. Hydrogeological zoning of mountainous regions of East Siberia. Proceedings of the 2nd Conference on groundwater and engineering geology of East Siberia. Irkutsk, Issue 1, p. 71-84 (in Russian) [Степанов В.M. Гидрогеологическая зональность в горных районах Восточной Сибири // Тр. II совещания по подземным водам и ин- 
женерной геологии Восточной Сибири. Иркутск, 1959. Вып. 1. С. 71-84].

Stepanov V.M., 1989. Introduction to Structural Hydrogeology. Nedra, Moscow, 229 р. (in Russian) [Степанов В.M. Введение в структурную гидрогеологию. М.: Недра, 1989. 229 с.].

Sultankhodzhaev A.N., Tyminsky V.G., Spiridonov A.I., 1979. Radioactive Emanations in Studies of Geological Processes. Fan, Tashkent, 119 p. (in Russian) [Султанходжаев А.Н., Тыминский В.Г., Спиридонов А.И. Радиоактивные эманации при изучении геологических процессов. Ташкент: Фан, 1979. 119 с.].

Suvorov V.D., Mishenkina Z.M., Petrick G.V., Sheludko I.F., Seleznev V.S., Solovyov V.M., 2002. Structure of the crust in the Baikal rift zone and adjacent areas from deep seismic sounding data. Tectonophysics 351 (1-2), 61-74. http://dx.doi.org/ 10.1016/S0040-1951(02)00125-7.

Suvorov V.D., Tubanov Ts.A., 2008. Distribution of local earthquakes in the crust beneath central Lake Baikal. Russian Geology and Geophysics 49 (8), 611-620. http://dx.doi.org/10.1016/j.rgg.2007.09.019.

Tat'kov G.I., 2009. Geophysical Monitoring of the Stress-and-Strain State of Natural and Technical Systems: Synopsis of PhD Thesis (Doctor of Sciences degree in geology and mineralogy), Irkutsk. 43 p. (in Russian) [Татьков Г.И. Геофизический мониторинг напряженно-деформированного состояния природных и технических систем: Автореф. дис. ... докт. геол.-мин. наук. Иркутск, 2009. 43 с.].

Ten Brink U.S., Taylor M.H., 2002. Crustal structure of central Lake Baikal: Insights into intracontinental rifting. Journal of Geophysical Research: Solid Earth 107 (B7), 2132. http://dx.doi.org/10.1029/2001JB000300.

The Method of Express Measurement of ${ }^{222}$ Rn activity in Soil Air by RRA Radon Radiometer, 2004. Recommendation. NPP Dose, Moscow, 16 p. (in Russian) [Методика экспрессного измерения объемной активности ${ }^{222} \mathrm{Rn}$ в почвенном воздухе с помощью радиометра радона типа РРА. Рекомендация. М: НПП «Доза», 2004. 16 с.].

The Neotectonic Map of the Baikal-Amur Railroad Area (Scale 1:3000000). Ed. N.A. Logatchev. IEC, Siberian Branch of the USSR Acad. Sci, Irkutsk, 1982 (in Russian) [Карта неотектоники региона Байкало-Амурской магистрали (м-б 1:3000000) / Отв. ред. Н.А. Логачев. Иркутск: ИЗК СО АН СССР, 1982].

Ufimtsev G.F., 1992. Morphotectonics of the Baikal rift zone. Nauka, Novosibirsk, 216 p. (in Russian) [Уфимцев Г.Ф. Морфотектоника Байкальской рифтовой зоны. Новосибирск: Наука, 1992. 216 с.].

Unsworth M.J., Bedrosian P.A., 2004. On the geoelectric structure of major strike-slip faults and shear zones. Earth, Planets and Space 56 (12), 1177-1184.

Unsworth M.J., Egbert G., Booker J., 1999. High-resolution electromagnetic imaging of the San Andreas fault in central California. Journal of Geophysical Research: Solid Earth 104 (B1), 1131-1150. http://dx.doi.org/10.1029/98JB01755.

Unsworth M.J., Malin P.E., Egbert G.D., Booker J.R., 1997. Internal structure of the San Andreas Fault at Parkfield. Geology 25 (4), 359-362. http://dx.doi.org/10.1130/0091-7613(1997)025<0359:ISOTSA>2.3.CO;2.

Viruete J.E., Carbonell R., Marti D., Jurado M.J., Perez-Estaun A., 2002. Architecture of fault zones determined from outcrop, cores, 3-D seismic tomography and geostatistical modeling: example from the Albala Granitic Pluton, SW Iberian Variscan Massif. Tectonophysics 361 (1-2), 97-120. http://dx.doi.org/10.1016/S0040-1951(02)00586-3.

Weber M., Abu-Ayyash K., Abueladas A., Agnon A., Alasonati-Tašárová Z., Al-Zubi H., Babeyko A., Bartov Y., Bauer K., Becken M., Bedrosian P.A., Ben-Avraham Z., Bock G., Bohnhoff M., Bribach J., Dulski P., Ebbing J., El-Kelani R., Förster A., Förster H.-J., Frieslander U., Garfunke Z., Goetze H.J., Haak V., Haberland C., Hassouneh M., Helwig S., Hofstetter A., Hoffmann-Rothe A., Jäcke K.H., Janssen C., Jaser D., Kesten D., Khatib M., Kind R., Koch O., Koulakov I., Laske G., Maercklin N., Masarweh R., Masri A., Matar A., Mechie J., Meqbe N., Plessen B., Möller P., Mohsen A., Oberhänsli R., Oreshin S., Petrunin A., Qabbani I., Rabba I., Ritter O., Romer R.L., Rümpker G., Rybakov M., Ryberg T., Saul J., Scherbaum F., Schmidt S., Schulze A., Sobolev S.V., Stiller M., Stromeyer D., Tarawneh K., Trela C., Weckmann U., Wetze U., Wylegalla K., 2009. Anatomy of the Dead Sea Transform from lithospheric to microscopic scale. Reviews of Geophysics 47 (2), RG2002. http://dx.doi.org/10.1029/2008RG000264.

Withjack M.O., Islam Q.T., La Pointe P.R., 1995. Normal faults and their hanging-wall deformation: an experimental study. American Association of Petroleum Geologists Bulletin 79 (1), 1-18.

Xiao Q., Zhao G., Dong Z., 2011. Electrical resistivity structure at the northern margin of the Tibetan plateau and tectonic implications. Journal of Geophysical Research: Solid Earth 116 (B12), B12401. http://dx.doi.org/10.1029/2010JB 008163.

Yakovlev A.V., Koulakov I.Yu., Tychkov S.A., 2007. Moho depths and three-dimensional velocity structure of the crust and upper mantle beneath the Baikal region, from local tomography. Russian Geology and Geophysics 48 (2), $204-220$. http://dx.doi.org/10.1016/j.rgg.2007.02.005.

Yungsheng S., Krylov S.V., Baojun Ya., Tsai L., Shisyue D., Techen L., Jingzhi L., Singzhyi S., Mishen'kina Z.R., Petrik G.V., Shelud'ko I.F., Seleznev V.S., Solovyev V.M., 1996. Deep seismic sounding of the lithosphere at the Baikal-Northeastern China international transect. Geologiya i Geofizika 37 (2), 3-15 (in Russian) [Юншен С., Крылов С.В., Баоцзюнь Я., Цай Л., Шисюэ Д., Течен Л., Цзинчжи Л., Синчжуй С., Мишенькина З.Р., Петрик Г.В., Шелудько И.Ф., Селезнев B.C., Соловьев B.M. Глубинное сейсмическое зондирование литосферы на международном трансекте Байкал Северо-Восточный Китай // Геология и геофизика. 1996. Т. 37. № 2. С. 3-15].

Zamaraev S.M., 1967. Marginal Structures of the Southern Part of the Siberian Platform. Nauka, Moscow, 248 p. (in Russian) [Замараев C.M. Краевые структуры южной части Сибирской платформы. М.: Наука, 1967. 248 с.]. 
Zamaraev S.M., Pavlov S.F., Vasiliev E.P., Mazukabzov A.M., Ruzhich V.V., Ryazanov G.V., 1979. The Ratio of Ancient and Cenozoic Structures in the Baikal Rift Zone. Nauka, Novosibirsk, 126 p. (in Russian) [Замараев С.М., Павлов С.Ф., Васильев Е.П., Мазукабзов А.М., Ружич В.В., Рязанов Г.В. Соотношение древней и кайнозойской структур в Байкальской рифтовой зоне. Новосибирск: Наука, 1979. 126 с.].

Zherebtsov G.A. (Ed.), 2012. Seismoionospheric and Seismoelectromagnetic Processes in the Baikal Rift Zone. Publishing House of SB RAS, Novosibirsk, 300 p. (in Russian) [Сейсмоионосферные и сейсмоэлектромагнитные процессы в Байкальской рифтовой зоне / Под ред. Г.А. Жеребцова. Новосибирск: Изд-во СО РАН, 2012. 300 с.].

Zhirova N.V., Mandelbaum M.M., Morozova G.M., Nevedrova N.N., Epov M.I., 1993. Geoelectric characteristics of seismogenic structures of the Baikal prognostic polygon. Geologiya i Geofizika 34 (1), 133-144 (in Russian) [Жирова Н.В., Мандельбаум М.М., Морозова Г.М., Неведрова Н.Н., Эпов М.И. Геоэлектрическая характеристика сейсмогенных структур Байкальского прогностического полигона // Геология и геофизика. 1993. Т. 34. № 1. С. 133-144].

Zorin Yu.A., Belichenko V.G., Turutanov E.Kh., Mordvinova V.V., Kozhevnikov V.M., Hozbayar P., Tomurtogoo O., Arvisbaatar N., Gao Sh., Davis P., 1994. The Baikal-Mongolian transect. Geologiya i Geofizika 7-8, 94-111 (in Russian) [Зорин Ю.А., Беличенко В.Г., Турутанов Е.Х., Мордвинова В.В., Кожевников В.М., Хозбаяр П., Томуртогоо О., Арвисбаатар Н., Гао Ш., Дэвис П. Байкало-Монгольский трансект // Геология и геофизика. 1994. № 7-8. С. 94$111]$.

Zorin Yu.A., Mordvinova V.V., Turutanov E.Kh., Belichenko B.G., Artemyev A.A., Kosarev G.L., Gao S.S., 2002. Low seismic velocity layers in the Earth's crust beneath Eastern Siberia (Russia) and Central Mongolia: receiver function data and their possible geological implication. Tectonophysics 359 (3-4), 307-327. http://dx.doi.org/10.1016/S0040-1951(02)005 31-0.

Zorin Yu.A., Turutanov E.Kh., 2005. Plumes and geodynamics of the Baikal rift zone. Russian Geology and Geophysics 46 (7), 669-682.
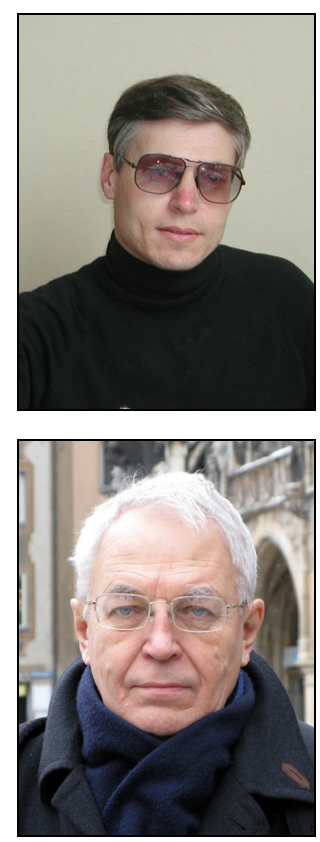

Семинский Константин Жанович, докт. геол.-мин. наук, зав. лабораторией тектонофизики Институт земной коры СО РАН

664033, Иркутск, ул. Лермонтова, 128, Россия

Тел.: 8(3952)423027; \ e-mail: seminsky@crust.irk.ru

Seminsky, Konstantin Zh., Doctor of Geology and Mineralogy, Head of Laboratory of Tectonophysics Institute of the Earth's Crust, Siberian Branch of RAS

128 Lermontov street, Irkutsk 664033, Russia

Tel.: 8(3952)423027; $\bowtie$ e-mail: seminsky@crust.irk.ru

Кожевников Николай Олегович, докт. геол.-мин. наук, г.н.с. лаборатории геоэлектрики Институт нефтегазовой геологии и геофизики им. А.А. Трофимука СО РАН 630090, Новосибирск, просп. академика Коптюга, 3, Россия Тел.: +7(383)3302816; e-mail: KozhevnikovNO@ipgg.sbras.ru

Kozhevnikov, Nikolai O., Doctor of Geology and Mineralogy, Chief Researcher of Laboratory of Geoelectrics A.A. Trofimuk Institute of Petroleum Geology and Geophysics SB RAS

3 Akademika Koptyuga Prosp., Novosibirsk 630090, Russia

Tel.: +7(383)3302816; e-mail: KozhevnikovNO@ipgg.sbras.ru 

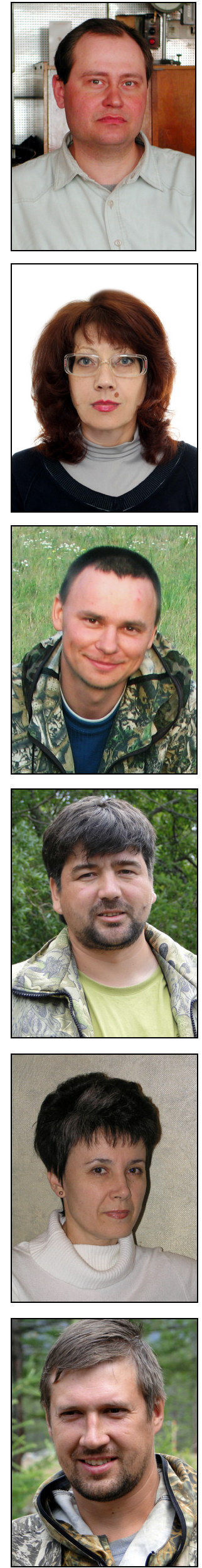

Черемных Александр Викторович, канд. геол.-мин. наук, с. н. с. Институт земной коры СО РАН

664033, Иркутск, ул. Лермонтова, 128, Россия

Тел.: 89501404851; e-mail: cherem@crust.irk.ru

Cheremnykh, Alexander V., Candidate of Geology and Mineralogy, Senior Researcher

Institute of the Earth's Crust, Siberian Branch of RAS

128 Lermontov street, Irkutsk 664033, Russia

Tel.: 89501404851; e-mail: cherem@crust.irk.ru

Поспеева Елена Валентиновна, докт. геол.-мин. наук, в.н.с. лаборатории геоэлектрики

Институт нефтегазовой геологии и геофизики им. А.А. Трофимука СО РАН

630090, Новосибирск, просп. академика Коптюга, 3, Россия

Тел.:+7(383)3302816; e-mail: PospeevaEV@ipgg.sbras.ru

Pospeeva, Elena V., Doctor of Geology and Mineralogy, Lead Researcher of Laboratory of Geoelectrics

A.A. Trofimuk Institute of Petroleum Geology and Geophysics SB RAS

3 Akademika Koptyuga Prosp., Novosibirsk 630090, Russia

Tel.: +7(383)3302816; e-mail: PospeevaEV@ipgg.sbras.ru

Бобров Александр Анатольевич, канд. геол.-мин. наук, м.н.с.

Институт земной коры СО РАН

664033, Иркутск, ул. Лермонтова, 128, Россия

Тел.: 89086603375; e-mail: alexbob@crust.irk.ru

Bobrov, Alexander A., Candidate of Geology and Mineralogy, Junior Researcher Institute of the Earth's Crust, Siberian Branch of RAS

128 Lermontov street, Irkutsk 664033, Russia

Tel.: 89086603375; e-mail: alexbob@crust.irk.ru

Оленченко Владимир Владимирович, канд. геол.-мин. наук, с.н.с. лаборатории геоэлектрики

Институт нефтегазовой геологии и геофизики им. А.А. Трофимука СО РАН

630090, Новосибирск, просп. академика Коптюга, 3, Россия

Тел.:+7(383)3307908; e-mail: OlenchenkoVV@ipgg.sbras.ru

Olenchenko, Vladimir V., Candidate of Geology and Mineralogy, Senior Researcher of Laboratory of Geoelectrics A.A. Trofimuk Institute of Petroleum Geology and Geophysics SB RAS

3 Akademika Koptyuga Prosp., Novosibirsk 630090, Russia

Tel.:+7(383)3307908; e-mail: OlenchenkoVV@ipgg.sbras.ru

Тугарина Марина Александровна, канд. геол.-мин. наук, доцент

Национальный исследовательский Иркутский государственный технический университет,

Институт недропользования, кафедра прикладной геологии

664074, Иркутск, ул. Лермонтова, 83, Россия

Тел.: 8(3952)412686; e-mail: Tmarina@istu.irk.ru

Tugarina, Marina A., Candidate of Geology and Mineralogy, assistant professor Irkutsk State Technical University (National Research University),

Institute of Subsoil Use, Applied Geology Chair

83 Lermontov street, Irkutsk 664074, Russia

Tel.: 8(3952)412686; e-mail: Tmarina@istu.irk.ru

Потапов Владимир Владимирович, канд. геол.-мин. наук, н.с. лаборатории геоэлектрики

Институт нефтегазовой геологии и геофизики им. А.А. Трофимука СО РАН

630090, Новосибирск, просп. академика Коптюга, 3, Россия

Тел.:+7(383)330 4122; e-mail: PotapovVV@ipgg.sbras.ru

Potapov, Vladimir V., Candidate of Geology and Mineralogy, Researcher of Laboratory of Geoelectrics A.A. Trofimuk Institute of Petroleum Geology and Geophysics SB RAS

3 Akademika Koptyuga Prosp., Novosibirsk 630090, Russia

Tel.:+7(383)330 4122; e-mail: PotapovVV@ipgg.sbras.ru 


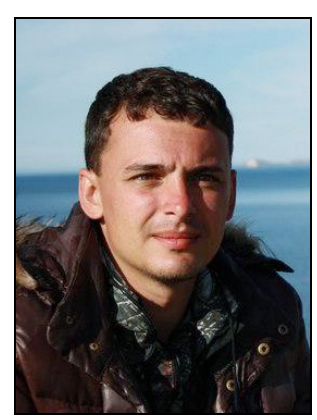

Зарипов Руслан Минерафитович, аспирант

Институт земной коры СО РАН

664033, Иркутск, ул. Лермонтова, 128, Россия

e-mail: rassell88@yandex.ru

Zaripov, Ruslan M., graduate student

Institute of the Earth's Crust, Siberian Branch of RAS

128 Lermontov street, Irkutsk 664033, Russia

e-mail: rassell88@yandex.ru

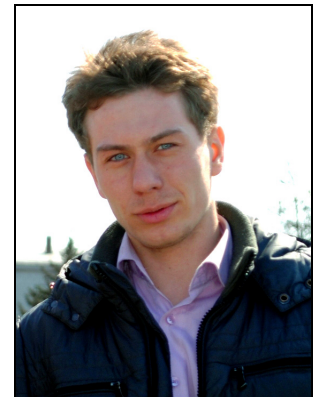

Черемных Алексей Сергеевич, аспирант

Институт земной коры СО РАН

664033, Иркутск, ул. Лермонтова, 128, Россия

e-mail: acherem@crust.irk.ru

Cheremnykh, Alexei S., graduate student

Institute of the Earth's Crust, Siberian Branch of RAS

128 Lermontov street, Irkutsk 664033, Russia

e-mail: acherem@crust.irk.ru 